\title{
Results of Macroinvertebrate Sampling Conducted at 33 SRS Stream Locations, July-August 1993 (U)
}

by

W. L. Specht

Westinghouse Savannah River Company

Savannah River Site

Aiken, South Carolina 29808

DOE Contract No. DE-AC09-89SR18035

This paper was prepared in connection with work done under the above contract number with the U. S.

Department of Energy. By acceptance of this paper, the publisher and/or recipient acknowledges the U.S. Government's right to retain a nonexclusive, royalty-free license in and to any copyright covering this paper, along with the right to reproduce and to authorize others to reproduce all or part of the copyrighted paper. 


\section{DISCLAIMER}

This report was prepared as an account of work sponsored by an agency of the United States Government. Neither the United States Government nor any agency thereof, nor any of their employees, makes any warranty, express or implied, or assumes any legal liability or responsibility for the accuracy, completeness, or usefulness of any information, apparatus, product, or process disclosed, or represents that its use would not infringe privately owned rights. Reference herein to any specific commercial product, process, or service by trade name, trademark, manufacturer, or otherwise does not necessarily constitute or imply its endorsement, recommendation, or favoring by the United States Government or any agency thereof. The views and opinions of authors expressed herein do not necessarily state or reflect those of the United States Government or any agency thereof.

This report has been reproduced directly from the best available copy.

Available to DOE and DOE contractors from the Office of Scientific and Technical Information, P.O. Box 62, Oak Riđge, TN 37831; prices available from (615) 576-8401.

Available to the public from the National Technical-Information Service, U.S. Department of Commerce, 5285 Port Royal Road, Springfield, VA 22161. 


\section{DISCLAIMER}

Portions of this document may be illegible in electronic image products. Images are produced from the best available original document. 


\title{
RESULTS OF MACROINVERTEBRATE SAMPLING CONDUCTED AT 33 SRS STREAM LOCATIONS, JULY-AUGUST 1993
}

WINONA L. SPECHT

Approved by:

\author{
Doprome-Shedros \\ D.B. Moore-Shedrow, Section Manager \\ Environmental Sciences Section \\ Savannah River Technology Center
}

Publication Date: December 1994

WESTINGHOUSE SAVANNAH RIVER COMPANY

SAVANNAH RIVER SITE

AIKEN, SC 29808

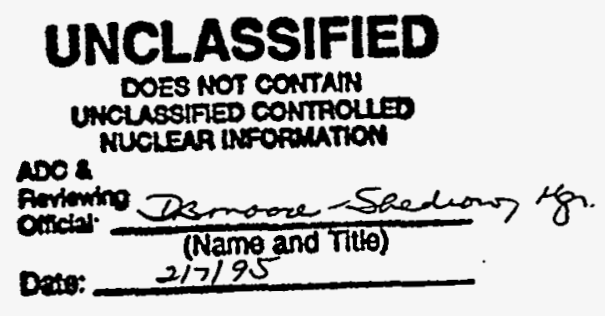

Prepared for the U.S. Department of Energy under Contract No. DE-AC09-88SR18035

DISTRIBUTION OF THIS DOCUMENT IS UNLIMIIED

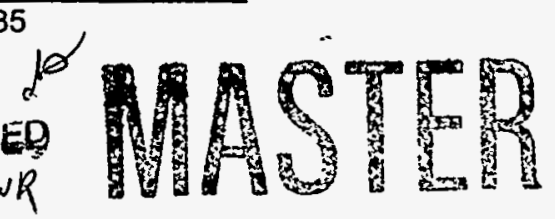




\section{TABLE OF CONTENTS}

\section{PAGE}

List of Tables iii

List of Figures iii

INTRODUCTION

$\begin{array}{ll}\text { METHODS } & 1\end{array}$

RESULTS 2

Physical and Chemical Parameters $\quad 2$

$\begin{array}{ll}\text { Upper Three Runs Macroinvertebrates } & 8\end{array}$

Macroinvertebrates in Tributaries of Upper Three Runs 8

Fourmile Branch Macroinvertebrates $\quad 12$

Pen Branch/Indian Grave Branch Macroinvertebrates 14

$\begin{array}{ll}\text { Steel Creek Macroinvertebrates } & 15\end{array}$

$\begin{array}{ll}\text { Lower Three Runs Macroinvertebrates } & 18\end{array}$

$\begin{array}{lr}\text { CONCLUSIONS } & 19\end{array}$

$\begin{array}{ll}\text { REFERENCES } & 20\end{array}$

APPENDIX A 


\section{LIST OF TABLES}

PAGE

Table 1. Locations for Macroinvertebrate Sampling, July-August 1993

Table 2. Physicochemical Measurements Taken in Conjunction with

6-7 Hester-Dendy Macroinvertebrate Samplers, July-August 1993.

Table 3. Upper Three Runs Macroinvertebrates, July-August 1993

Table 4. Relative Abundance (\%) of Common Macroinvertebrate Taxa in SRS Streams, July-August 1993.

Table 5. Macroinvertebrates in Tributaries of Upper Three Runs, July-August 1993

Table 6. Fourmile Branch Macroinvertebrates, July-August 1993

Table 7. Pen Branch and Indian Grave Branch Macroinvertebrates, July-August 1993

Table 8. Steel Creek and Lower Three Runs Macroinvertebrates

\section{LIST OF FIGURES}

PAGE

Figure 1. Map of Sampling Locations for Macroinvertebrates, July-August 1993

Figure 2. Hester-Dendy Multiplate Sampler 


\section{RESULTS OF MACROINVERTEBRATE SAMPLING CONDUCTED AT 33 SRS STREAM LOCATIONS, JULY-AUGUST 1993}

\section{INTRODUCTION}

In order to assess the health of the macroinvertebrate communities of SRS streams, the macroinvertebrate communities at 30 stream locations on SRS were sampled during the summer of 1993, using Hester-Dendy multiplate samplers. In addition, three off-site locations in the Upper Three Runs drainage were sampled in order to assess the potential for impact from off-site activities. In interpreting the data, it is important to recognize that these data were from a single set of collections. Macroinvertebrate communities often undergo considerable temporal variation, and are also greatly influenced by such factors as water depth, water velocity, and available habitat. These stations were selected with the intent of developing an on-going sampling program at a smaller number of stations, with the selection of the stations to be based largely upon the results of this preliminary sampling program. When stations within a given stream showed similar results, fewer stations would be sampled in the future. Similarly, if a stream appeared to be perturbed, additional stations or chemical analyses might be added so that the source of the perturbation could be identified.

In general, unperturbed streams will contain more taxa than perturbed streams, and the distribution of taxa among orders or families will differ. Some groups of macroinvertebrates, such as Ephemeroptera (mayflies), Plecoptera (stoneflies) and Trichoptera (caddisflies), which are collectively called EPT taxa, are considered to be relatively sensitive to most kinds of stream perturbation; therefore a reduced number of EPT taxa generally indicates that the stream has been subject to chemical or physical stressors. In coastal plain streams, EPT taxa are generally less dominant than in streams with rocky substrates, while Chironomidae (midges) are more abundant. Within the Chironomidae, some groups, such as the Orthocladiinae are sensitive to environmental perturbation, while groups such as Chironomini and Tanypodinae have been shown to be much more resistant to perturbations (Heliovaara and Vaisanen, 1993).

The density of organisms (number per square meter) and biomass (mass per square meter) also provide useful information about the ecological integrity of a stream. Very low density or biomass, or very high density or biomass, when associated with a large reduction in the number of taxa, are all indications of perturbation. Similarly, shifts in the relative abundance of functional feeding groups generally indicates that there have been changes in the availability of food types, and can also be indications of stress (Merritt and Cummins, 1978). By examining all of these measurements, the overall health of the macroinvertebrate community and the stream as a whole can be assessed.

\section{METHODS}

Sampling was conducted in Upper Three Runs (six locations), eight tributaries of Upper Three Runs [Cedar Creek, Boggy Gut, Tinker Creek (two locations), Reedy Branch, Mill Creek, McQueen's Branch, Crouch Branch, and Tims Branch (two locations)], Four Mile 
Creek (six locations), Indian Grave Branch, Pen Branch (five locations), Steel Creek (two locations), a tributary of Steel Creek, and Lower Three Runs (two locations). In all, 33 locations were sampled (Table 1; Figure 1).

At each sampling location, five replicate Hester-Dendy multiplate samplers (Figure 2), each having a surface area of $0.179 \mathrm{~m}^{2}$ were deployed and allowed to colonize for 28 days. The samplers were retrieved and returned to the laboratory for processing. In the laboratory, the samplers were disassembled and organisms were gently removed from the plates using a soft brush or a stream of water from a wash bottle. Organisms were preserved in $70 \%$ ethanol until identified. Organisms were identified to the lowest practical taxon (usually genus). Parameters reported included total number of taxa collected at each station, mean number of taxa per sampler, density of organisms (number per $\mathrm{m}^{2}$ ), EPT (number of Ephemeroptera, Plecoptera, and Trichoptera taxa collected at a station), biotic index, ratio of scrapers to collector-filterers, biomass ( $\mathrm{g}$ ash free dry weight $/ \mathrm{m}^{2}$ ), relative abundance of functional feeding groups, relative abundance of functional feeding group biomass, relative abundance of major taxonomic groups (usually order), and a listing of all taxa which comprised greater than $5 \%$ of the macroinvertebrates collected at each station. The raw data for each station are presented in Appendix A.

At the time of sampler retrieval, physical and chemical measurements were taken at each station. Parameters included water hardness, $\mathrm{pH}$, conductivity, dissolved oxygen, temperature, water velocity, stream width, and stream depth at one meter intervals across the stream (see Appendix A for stream profiles).

\section{RESULTS}

\section{Physical and Chemical Parameters}

Water hardness ranged from $8 \mathrm{mg} / \mathrm{l}$ at Stations 1,2 , and 18 to $66 \mathrm{mg} / \mathrm{l}$ at Station 15 (Table 2). Conductivity ranged from 15 umhos $/ \mathrm{cm}$ at Station 1 to 105 umhos $/ \mathrm{cm}$ at Station 12 (Table 2). pH ranged from 4.89 at Station 2 to 7.2 at Station 24 (Table 2). The acceptable range for $\mathrm{pH}$ in South Carolina streams is 6.0 to 8.5 (SCDHEC 1993). Eleven of the 33 locations that were sampled had pH values of less than 6 . However, these are blackwater streams with naturally low $\mathrm{pH}$. $\mathrm{pH}$ is not considered to be a limiting factor for most macroinvertebrates in SRS streams.

Dissolved oxygen concentrations ranged from $0.2 \mathrm{mg} / \mathrm{l}$ at Station 25 to $8.7 \mathrm{mg} / \mathrm{l}$ at Station 24 (Table 2). Dissolved oxygen concentrations of less than $5 \mathrm{mg} / \mathrm{l}$ are considered undesirable in South Carolina streams (SCDHEC 1993). Six of the sampling locations had dissolved oxygen levels of less than $5 \mathrm{mg} / \mathrm{l}$. Based on the biological data, it appears that low dissolved oxygen levels were responsible for most of the perturbation observed in the streams. Although additional studies will be needed to determine the cause of the low dissolved oxygen levels, at present, it is believed to be due primarily to the presence of beaver dams or other blockage of the stream channel upstream from the sampling locations. Pooling of stream water can often result in anoxic conditions, particularly during the summer months, when water temperatures are warm and bacterial action in the water and sediments is high. 
TABLE 1. LOCATIONS FOR MACROINVERTEBRATE SAMPLING JULY-AUGUST 1993

\begin{tabular}{|c|c|c|}
\hline STATION & STREAM & LOCATION \\
\hline 1 & Upper Three Runs & Banks Mill Road \\
\hline 2 & Cedar Creek & Banks Mill Road \\
\hline 3 & Boggy Gut & Road 781.4 \\
\hline 4 & Upper Three Runs & Road 8-1 \\
\hline 5 & Tinker Creek & Kennedy Pond Road \\
\hline 6 & Tinker Creek & Road 2-1 \\
\hline 7 & Reedy. Branch & Road 8-1 \\
\hline 8 & Mill Creek & Road E-2 \\
\hline 9 & McQueen's Branch & Road F \\
\hline 10 & Tim's Branch & Road 2 \\
\hline 11 & Tim's Branch & Road C \\
\hline 12 & Crouch Branch & Road 4 \\
\hline 13 & Upper Three Runs & Road C \\
\hline 14 & Fourmile Branch & Road C-4 \\
\hline 15 & Fourmile Branch & Road C \\
\hline 16 & Fourmile Branch & Road 4 \\
\hline 17 & Fourmile Branch & Road E-1 \\
\hline 18 & Upper Three Runs & Road A \\
\hline 19 & Fourmile Branch & Road A-7 \\
\hline 20 & Fourmile Branch & Road A-13.2 \\
\hline 21 & Indian Grave Branch & Road B \\
\hline 22 & Pen Branch & Road B \\
\hline 23 & Pen Branch & Road A \\
\hline 24 & Pen Branch & Road A-13.2 \\
\hline 25 & Pen Branch & Boardwalk \\
\hline 26 & Pen Branch & Road C \\
\hline 27 & Steel Creek & Road B \\
\hline 28 & Steel Creek & Road A \\
\hline 29 & Steel Creek Tributary & Road A \\
\hline 30 & Lower Three Runs & Donora Station \\
\hline 31 & Lower Three Runs & Patterson's Mill \\
\hline 32 & Upper Three Runs & Railroad Bridge \\
\hline 33 & Upper Three Runs & Road F \\
\hline
\end{tabular}


FIGURE 1. MAP OF SAMPLING LOCATIONS FOR MACROINVERTEBRATES, JULY-AUGUST 1993

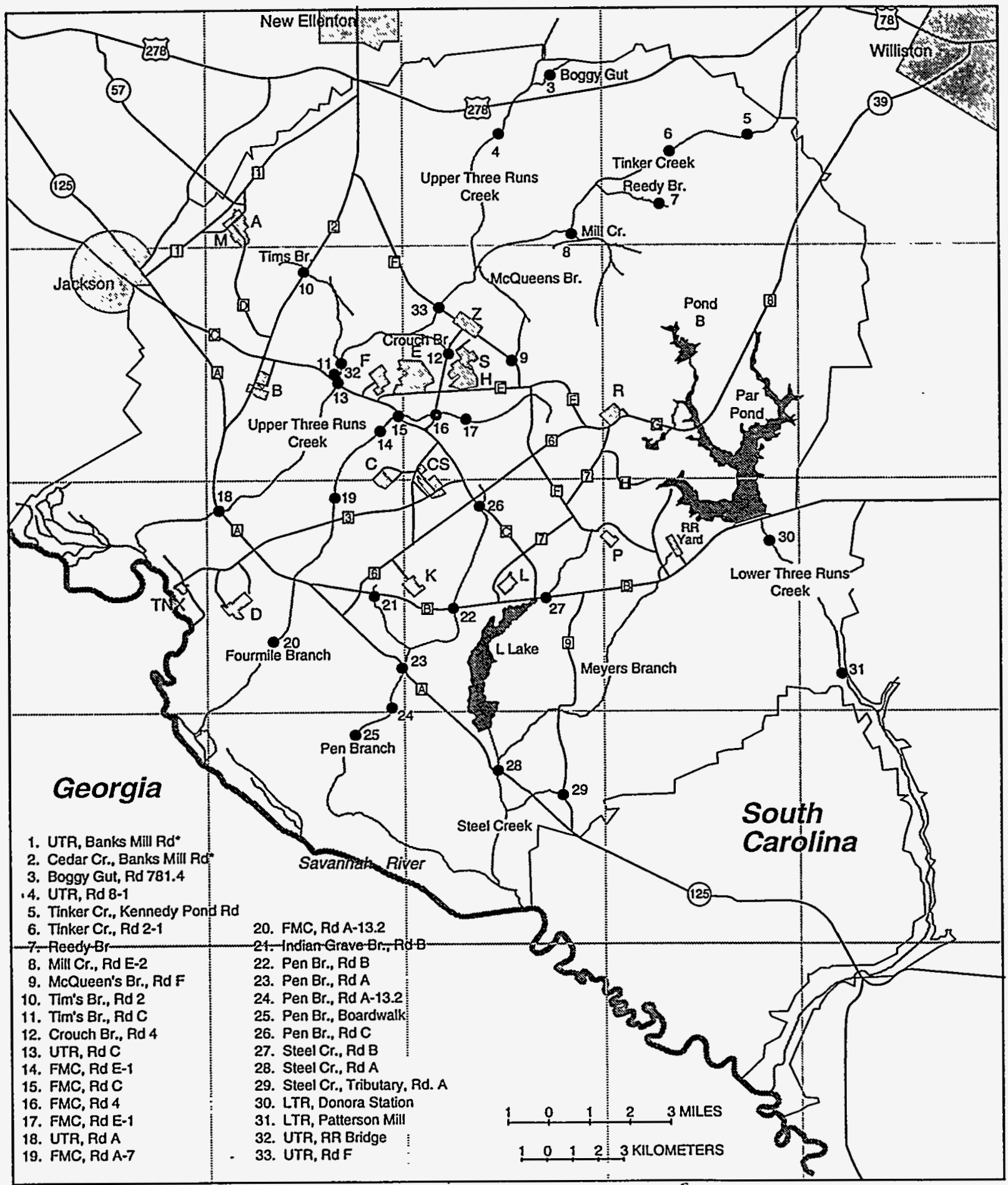

95X00155.01.AlL

-Located north of SRS: not shown on map 
FIGURE 2. HESTER-DENDY MULTIPLATE SAMPLER

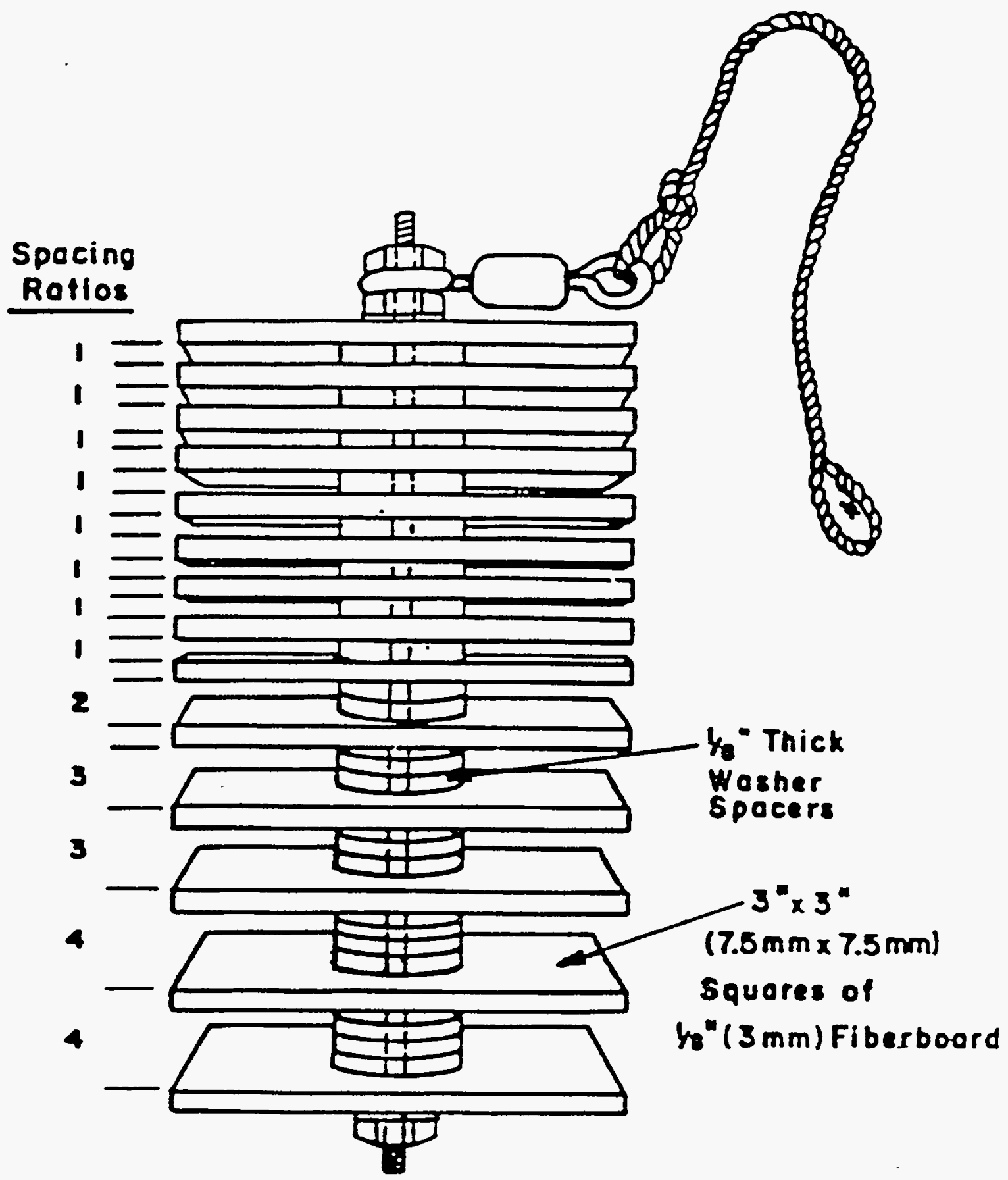


TABLE 2. PHYSICOCHEMICAL MEASUREMENTS TAKEN IN CONJUNCTION WITH HESTER-DENDY MACROINVERTEBRATE SAMPLES, JULY-AUGUST 1993. MEASUREMENTS WERE TAKEN ON SAMPLER RETRIEVAL DATE

\begin{tabular}{|c|c|c|c|c|c|c|c|c|c|c|c|c|c|c|c|c|c|}
\hline Station \# & 1 & 2 & 3 & 4 & 5 & 8 & 7 & 8 & 9) & 10 & 11 & 12 & 13 & 14 & 15 & 18 & 17 \\
\hline & & & & & & & & & & & & & & & & & \\
\hline Placement Date & $7 / 22 / 93$ & $7 / 22 / 93$ & 7122193 & $7 / 22 / 83$ & $7 / 22 / 93$ & $7 / 22 / 93$ & 7122193 & $7 / 22 / 83$ & $7 / 23 / 93$ & $7 / 24 / 93$ & $7 / 24 / 93$ & $7 / 22 / 93$ & $7 / 24 / 93$ & $7 / 23 / 93$ & $7 / 23 / 93$ & $7 / 22 / 93$ & $7 / 22 / 93$ \\
\hline Retrieval Date & $8 / 19 / 93$ & $8 / 19 / 93$ & $8 / 19 / 93$ & $8 / 19 / 93$ & $8 / 18 / 93$ & $8 / 19 / 93$ & $8 / 19 / 93$ & $\begin{array}{r}8 / 19 / 93 \\
\end{array}$ & $8 / 20 / 93$ & $8 / 19 / 93$ & $8 / 19 / 93$ & $8 / 20 / 93$ & $8 / 20 / 93$ & $8 / 20 / 93$ & $8 / 20 / 93$ & $8 / 20 / 93$ & $8 / 20 / 93$ \\
\hline Time & $8: 55 \mathrm{AM}$ & $8: 05 \mathrm{AM}$ & $2: 20 \mathrm{AM}$ & 10:20 $\mathrm{NM}$ & $11: 20 \mathrm{mM}$ & 11:55 AM & $12: 30 \mathrm{PM}$ & 12:50 PM & 2:20 PM & $7.05 \mathrm{PM}$ & 8:50 PM & $8: 15 \mathrm{AM}$ & $1: 50 \mathrm{PM}$ & 10:20 MM & 1:30 PM & 8:30 AM & $9: 85 \mathrm{MM}$ \\
\hline Hardness (mg/l) & 8.0 & 8.0 & 10 & 10 & 30 & 20 & 40 & 32 & 30 & 17 & 20 & 13 & 21 & 20 & 86 & 14 & 38 \\
\hline $\mathrm{pH}(\mathrm{SU})$ & 4.97 & 4.89 & 5.19 & 5.47 & 6.13 & 8.33 & 0.21 & 8.34 & 0.18 & 6.69 & 6.71 & 5.46 & 8.59 & 6.02 & 8.13 & 5.79 & 5.69 \\
\hline Conductivity (umhos $/ \mathrm{cm}$ ) & 15.0 & 20.0 & 20.0 & 20.0 & 35.0 & 25.0 & 40.0 & 55.0 & 45.0 & 65.0 & 80.0 & 105.0 & 20.0 & 75.0 & 100.0 & 80.0 & 35.0 \\
\hline DO $(\mathrm{mg} / 1)$ & 7.6 & 7.4 & 8.7 & 7.8 & 6.7 & 7.4 & 7.2 & 7.8 & 7.6 & 5.2 & 7.0 & 4.4 & 8.0 & 7.2 & 0.8 & 7.5 & 4.0 \\
\hline Tomporature (C) & 22.6 & 22.7 & 24.1 & 23.8 & 27.4 & 25.7 & 28.4 & 28.4 & 25.7 & 25.7 & 25.4 & 23.4 & 25.3 & 25.5 & 27.2 & 24.0 & 25.3 \\
\hline Flow $(\mathrm{m} / \mathrm{s})$ & 0.43 & 0.25 & 0.48 & 0.37 & 0.21 & 0.32 & 0.04 & 0.01 & 0.02 & 0.50 & 0.40 & 0.00 & 0.47 & 0.37 & 0.30 & 0.35 & 0.00 \\
\hline Stream Width $(\mathrm{m})$ & 7.50 & 4.42 & 2.80 & 12.19 & 8.99 & 8.50 & 1.95 & 6.16 & 2.59 & 2.07 & 2.87 & 0.91 & 15.84 & 3.17 & 7.25 & 2.83 & 2.50 \\
\hline (motors from laft bank) Depth & & & & & & & & & & & & & & & & & \\
\hline Depth 1 & 190 & (0) 0 & 1010 & 1010 & 1010 & 1010 & 1010 & (0) 0 & (10) 0 & (0) 0 & (10) 0 & 1010 & $(0) 0$ & (0) 0 & 1010 & 1010 & 1010 \\
\hline Dopth 2 & $(0.7) 0.3$ & $(0.6) 0.12$ & $(0.5) 0.12$ & $(1.1) 1.01$ & 10.810 .27 & $(0.8) 0.68$ & $(0.3) 0.52$ & 0.610 .48 & 10.410 .15 & $(0.3) \quad 0.49$ & 0.510 .30 & $(0.3) 0.12$ & $(1.4) 0.82$ & 10.410 .09 & 10.710 .67 & $(0.5) 0.12$ & $(0.4) 0.34$ \\
\hline Qopth 3 & $(1.4) 0.55$ & 11.110 .49 & $(0.9) 0.30$ & $(2.2) 1.74$ & $(1.6) 0.46$ & $(1.6) 0.65$ & $(0.5) 0.58$ & $(1.0) 0.73$ & $(0.9) 0.18$ & $(0.5) 0.46$ & $(1.090 .30$ & $10.5) 0.27$ & (2.8) 0.70 & 10.810 .40 & $(1.3) 0.73$ & $(1.0) 0.09$ & $(0.8) 0.58$ \\
\hline Dopth 4 & $(2.0) 0.87$ & $(1.7) 0.55$ & $(1.4) 0.30$ & $(3.3) 1.40$ & $(2.5) 0.62$ & $(2.3) \quad 0.52$ & 10.810 .52 & $(1.7) \quad 0.91$ & $(1.3) 0.15$ & $(1.0) 0.43$ & (1.5) 0.24 & $(0.8) 0.08$ & $(4.3) 0.70$ & (1.2) 0.37 & 12.010 .91 & $(1.4) 0.09$ & (1.3) 0.52 \\
\hline Dopth 5 & $(2.7) \quad 0.70$ & $(2.2) 0.58$ & $\begin{array}{lll}(1.8) & 0.37\end{array}$ & $(4.4) 0.91$ & $(3.3) 0.64$ & $(3.1) 0.46$ & $(1.0) 0.52$ & (2.3) 1.01 & 11.710 .12 & $(1.3) 0.34$ & (1.9) 0.18 & $(0.8) 0$ & $(5.7) 0.76$ & $(1.010 .49$ & $(2.6) 1.16$ & $(1.9) 0.15$ & $(1,7) 0.49$ \\
\hline Dopth 6 & $(3.4) 0.64$ & $(2.8) 0.43$ & $(2.4) \quad 0.40$ & $(5.6) 0.79$ & $(4.110 .81$ & $(3.9) \quad 0.30$ & (1.3) 0.49 & $(2.8) 0.82$ & $(2.2) 0.08$ & (1.5) 0.15 & $(2.4) 0.12$ & & $(7.1) 0.81$ & 12.010 .46 & $(3.3) 1.16$ & $(2.4) 0.24$ & $(2.1) 0.40$ \\
\hline Oopth 7 & $(4.11) 0.46$ & $(3.3) \quad 0.30$ & $(2.8) 0$ & $(8.7) 0.73$ & $(4.9) \quad 0.61$ & $(4.6) 0.24$ & $(1.5) 0.30$ & $(3.4) 0.79$ & 12.610 & 12.010 & $(2.8) 0$ & & $(8.5) 0.79$ & $(2.4) 0.37$ & 14.011 .16 & (2.9) 0 & $(2.5) 0$ \\
\hline Oopth B & $(4.8) 0.46$ & (3.9) 0.15 & & $(7.8) 0.76$ & $(5.7) 0.70$ & $(5.4) \quad 0.30$ & $(11.8) 0.12$ & $(3.9) 0.67$ & & & & & $(9.9) 0.70$ & $(2.8) 0.34$ & $(4.6) 1.13$ & & \\
\hline Dopth 9 & $(5.4) 0.40$ & $(4.4) 0$ & & $(8.8) 0.34$ & $(6.6) 0.73$ & $(6.2) 0.37$ & 12.010 & $(4,6) 0.67$ & & & & & 119.310 .07 & $(3.2) 0$ & $(5.3) 1.10$ & & \\
\hline Dopth 10 & $(6.11) 0.40$ & & & $(10) 0.24$ & $(7.4) 0.67$ & $(7.0) 0.27$ & & $(6.1) 0.70$ & & & & & \multicolumn{2}{|l|}{ (12.810.61 } & (5.9)1.01 & & \\
\hline Dopth 11 & $(6.8) 0.40$ & & & $(11.110 .00$ & $(8.2) 0.40$ & $(7.7) .018$ & & $(5.6) 0.18$ & & & & & & 16.610 .98 & & \\
\hline Dopth 12 & $(7.5) 0$ & & & $112.2) 0$ & 19.010 & 18.510 & & $(6.2) 0$ & & & & & \multicolumn{2}{|l|}{\begin{tabular}{|l|}
$(14.2) 0.30$ \\
$15.6) 0$
\end{tabular}} & 17.310 & & \\
\hline
\end{tabular}


TABLE 2 (continued). PHYSICOCHEMICAL MEASUREMENTS TAKEN IN CONJUNCTION WITH HESTER-DENDY MACROINVERTEBRATE SAMPLES, JULY-AUGUST 1993. MEASUREMENTS WERE TAKEN ON SAMPLER RETRIEVAL DATE.

\begin{tabular}{|c|c|c|c|c|c|c|c|c|c|c|c|c|c|c|c|c|}
\hline Station \# & 18 & 19 & 20 & 21 & 22 & 23 & 24 & 25 & 26 & 27 & 28 & 29 & 30 & 31 & 32 & 33 \\
\hline Placement Date & $7 / 23 / 93$ & $7 / 23 / 93$ & $7 / 22 / 93$ & $7 / 22 / 93$ & $7 / 22 / 93$ & $7 / 23 / 93$ & $7 / 23 / 93$ & $7 / 23 / 93$ & $7 / 23 / 93$ & $7 / 22 / 93$ & 7/23/93 & $7 / 24 / 93$ & $7 / 24 / 93$ & $7 / 24 / 93$ & $7 / 24 / 93$ & $7 / 23 / 93$ \\
\hline Retrieval Date & $8 / 19 / 93$ & $8 / 20 / 93$ & $8 / 20 / 93$ & $8 / 19 / 93$ & $8 / 19 / 93$ & $8 / 19 / 93$ & $8 / 20 / 93$ & $8 / 20 / 93$ & $8 / 20 / 93$ & $8 / 19 / 93$ & $8 / 19 / 93$ & $8 / 19 / 93$ & $8 / 19 / 93$ & $8 / 19 / 93$ & $8 / 20 / 93$ & $8 / 20 / 93$ \\
\hline Time & 0:00 PM & 10:50 AM & 11:35 AM & 4:10 PM & 3:50 PM & 5:35 PM & 12:05 Pि. & $12: 25 \mathrm{PM}$ & 1:10 PM & 3:07 PM & 5:10 PM & 4:45 PM & $1: 30 \mathrm{PM}$ & 2:20 PM & 8:00 AM & 7:35 AM \\
\hline Hardness (mg/l) & 8.0 & 16 & 25 & 16 & 24 & 20 & 31 & 31 & 44 & 12 & 27 & 13 & 18 & 23 & 11 & 26 \\
\hline $\mathrm{pH}(\mathrm{SU})$ & 6.4 & 6.2 & 7.0 & 6.3 & 6.3 & 6.4 & 7.2 & 6.2 & 5.3 & 6.6 & 6.0 & 5.3 & 6.5 & 6.4 & 5.8 & 5.4 \\
\hline Conductivity (umhos $/ \mathrm{cm}$ ) & 20.0 & 75.0 & 70.0 & 80.0 & 45.0 & 70.0 & 75.0 & 90.0 & 25.0 & 60.0 & 65.0 & 30.0 & 50.0 & 65.0 & 25.0 & 60.0 \\
\hline$D O(\mathrm{mg} / \mathrm{l})$ & 7.5 & 7.4 & 7.9 & 8.3 & 7.2 & 8.2 & 8.7 & 0.2 & 2.1 & 7.8 & 6.5 & 3.7 & 5.8 & 7.4 & 7.7 & 7.5 \\
\hline Temperature (C) & 24.60 & 26.30 & 27.20 & 29.00 & 27.90 & 28.90 & 27.50 & 29.60 & 24.00 & 32.70 & 30.20 & 29.00 & 31.30 & 28.60 & 23.20 & 22.60 \\
\hline Flow $(\mathrm{m} / \mathrm{s})$ & 0.49 & 0.55 & 0.12 & 0.18 & 0.17 & 0.22 & 0.35 & 0.00 & 0.00 & 0.00 & 0.38 & 0.00 & 0.44 & 0.18 & 0.42 & 0.25 \\
\hline Stream width $(\mathrm{m})$ & 14.63 & 3.66 & 13.11 & 12.13 & 3.38 & 10.61 & 0.42 & NA & 1.16 & 33.53 & 11.28 & 3.60 & 7.50 & 13.35 & 13.05 & 9.75 \\
\hline \multicolumn{17}{|l|}{ (meters from Left bank) Depth } \\
\hline Depth 1 & (0) 0 & (0) 0 & 1010 & 1010 & $(0) 0$ & (0) 0 & (0) 0 & 0.21 & (0) 0 & $(0) 0$ & $10) 0$ & (0) 0 . & (0) 0 & (0) 0 & (0) 0 & (0) 0 \\
\hline Depth 2 & (1.3) 0.82 & $(0.6) 0.06$ & $(1.2) 0.37$ & $(1.1) 0.30$ & $(0.6) 0.6$ & $(1.0) 0.62$ & $(0.9) \quad 0.15$ & 0.37 & $(0.9) 0.61$ & (3.1) 1.86 & $(1.0) 0.73$ & $(0.5) 0.15$ & $(0.7) 0.24$ & $(1.2) 0.68$ & $(1.2) 0.49$ & $(0.9) 0.08$ \\
\hline Depth 3 & $(2.7) 1.10$ & $(1.1) 0.09$ & $(2.4) 0.58$ & $(2.2) 0.65$ & $(1.1) 0.09$ & $(1.9) 0.40$ & $(1.9) 0.18$ & & (1.9) 0.68 & $(0.1) 2.44$ & (2.1) 1.01 & $(0.8) 0.21$ & $(1.4) 0.01$ & (1.4) 1.01 & $(2.4) 1.18$ & $(1.8) 0.66$ \\
\hline Depth 4 & $(4.0) 1.31$ & (1.7) 0.15 & (3.0) 0.49 & (3.3) 0.67 & 11.70 .15 & (2.9) 0.34 & $(2.8) 0.18$ & & $(2.9) 0.34$ & $(9.1) 2.29$ & $(3.1) 1.25$ & $(1.4) 0.65$ & $(2.1) \quad 0.73$ & $(3.6) 1.07$ & $(3.6) 1.25$ & $(2.7) 0.70$ \\
\hline Depth 5 & (5.3) 1.37 & (2.3) 0.12 & (4.8) 0.52 & $(4.4) 0.70$ & (2.3) 0.12 & (3.9) 0.46 & $(3.8) 0.21$ & & $(3.8) 0$ & $(12.2) 2.2$ & $(4.1) 1.10$ & $(1.8) 0.63$ & $(2.7) 0.67$ & $(4.8) 1.07$ & $(4.8) 1.28$ & $(3.6) 0.84$ \\
\hline Depth 6 & $(8.6) 1.34$ & $(2.8) 0.15$ & $(5.9) 0.43$ & $(8.8) 0.73$ & $(2.8) 0.15$ & (4.8) 0.62 & $(4.7) \quad 0.21$ & & & $(16.2) 2.23$ & $(5.1) 1.13$ & (2.3) 0.05 & $(3.4) 0.68$ & $(6.1) 1.10$ & $(5.9) 1.22$ & $(4.4) 0.98$ \\
\hline Depth 7 & $(8.0) 1.22$ & $(3.4) 0$ & $(7.1) 0.37$ & $(9.9) 0.48$ & $(3.4) 0$ & (5.8) 0.01 & $(5.7) 0.27$ & & & $(18.312 .23$ & $(8.2) 0.98$ & $(2.7) 0.52$ & $(4.1) 0.62$ & (7.3) 1.10 & $(7.1) 1.19$ & (5.3) 1.18 \\
\hline Depth 8 & $(9.3) 1.07$ & & $(8.3) 0.43$ & $(11.0) 0.27$ & & $(6.7) 0.61$ & $(0.0) 0.34$ & & & $(21.312 .18$ & $(7.2) 0.79$ & $(3.1) 0.15$ & $(4.8) 0.52$ & (8.6) 0.98 & $(8.3) 1.22$ & $(8.2) 1.13$ \\
\hline Depth 9 & $(10.6) 0.91$ & & $(9.5) 0.52$ & $(12.1) 0$ & & (7.7) 0.70 & $(7.6) \quad 0.37$ & & & $(24.0) 2.74$ & $(8.2) 0.70$ & $(3.6) 0$ & $(5.6) 0.40$ & $(9.7) 0.98$ & $(9.5) 1.07$ & $(7.1) 1.37$ \\
\hline Depth 10 & $(12.0) 0.91$ & & $(10.7) 0.81$ & & & $(8.7) 0.73$ & $(8.5) 0.48$ & & & $(27.412 .29$ & $(9.3) 0.84$ & & $(6.1) 0.43$ & $(10.910 .01$ & $(10.710 .61$ & $(7.9) 1.37$ \\
\hline Depth 11 & $(13.3) 0.64$ & & $(11.9) 0.52$ & & & $(9.6) 0.01$ & $(9.5) 0.67$ & & & $(30.5) 1.58$ & $(10.3) 0.64$ & & $(0.8) 0.30$ & $(12.1) 0.15$ & $(11.910 .49$ & $(8.8) 1.56$ \\
\hline Depth 12 & $(14.0) 0$ & & $(13.1) 0$ & & & $(10.6) 0$ & $(10.4) 0$ & & & $(33.5) 0$ & $(11.3) 0$ & & $(7.6) 0$ & $(13.3) 0$ & 113.110 & $19.7) 0$ \\
\hline
\end{tabular}


Water velocity ranged from $0.0 \mathrm{~m} / \mathrm{sec}$ at several sampling stations to $0.55 \mathrm{~m} / \mathrm{sec}$ at Station 19 (Table 2). Stream width ranged from $0.42 \mathrm{~m}$ at Station 24 to $33.53 \mathrm{~m}$ at Station 27 (Table 2). Maximum stream depth ranged from $0.15 \mathrm{~m}$ at Stations 19 and 22 to $2.44 \mathrm{~m}$ at Station 27 (Table 2).

\section{Upper Three Runs Macroinvertebrates}

Upper Three Runs has long been considered to be the most unperturbed of the five major SRS streams. However, Upper Three Runs and three of its tributaries (Tim's Branch, McQueen's Branch and Crouch Branch) collectively receive effluents from 23 NPDES outfalls in $A, B, F, H, M$, and $S$ Areas and the Flowing Streams Facility near Road C.

The macroinvertebrate data from Upper Three Runs indicate that the stream supports a reasonably rich macroinvertebrate community at each of the six locations that were sampled. The total number of taxa collected per station ranged from 42 at Road $F$ to 52 at Road C, while the mean number of taxa collected per sampler ranged from 20.0 at Banks Mill Road to 26.8 at Road C (Table 3). Density of organisms ranged from 444.7 organisms $/ \mathrm{m}^{2}$ at Road $F$ to 1378.8 organisms $/ \mathrm{m}^{2}$ at the Railroad Bridge upstream from Road C (Table 3). EPT ranged from 12 to 27 (Table 3). Biomass ranged from $0.0296 \mathrm{~g} / \mathrm{m}^{2}$ at Road $A$ to $0.8470 \mathrm{~g} / \mathrm{m}^{2}$ at Road $8-1$ (Table 3). Usually, high biomasses, such as that reported at Road 8-1 are due to the presence of a few large organisms. The most abundant group of macroinvertebrates collected at all of the Upper Three Runs stations were the orthoclad chironomids (33.67\% to $56.97 \%$; Table 3 ). The most common orthoclad taxa were Rheocricotopus, Cricotopus/Ortho, and Thienemaniella; Table 4). Other abundant groups of taxa included Tanytarsini chironomids (6.89 to 25.98\%; dominant taxa were Rheotanytarsus and Tanytarsus), Chironomini chironomids ( 3.40 to $18.38 \%$; dominant taxa was Polypedilum), Trichoptera ( 4.07 to $8.66 \%$ ), and Coleoptera ( 1.7 to $15.58 \% ;$ dominant taxa were Stenelmis crenatus and Macronychus glabratus; Tables 3 and 4). No longitudinal (upstream to downstream) trends were observed for any of the parameters that were measured.

\section{Macroinvertebrates in Tributaries of Upper Three Runs}

Tributaries of Upper Three Runs that were sampled include Cedar Creek (off-site), Boggy Gut (off-site), Tinker Creek, Reedy Branch, Mill Creek, McQueen's Branch, Tim's Branch, and Crouch Branch. Of these tributaries, McQueen's Branch, Crouch Branch, and Tim's Branch receive effluents from SRS facilities, while the remaining tributaries are largely unperturbed. The macroinvertebrate data indicate that McQueen's Branch, Crouch Branch, and Tim's Branch all appear to be perturbed to some extent, as evidenced by fewer total taxa and mean taxa per sampler, lower densities of organisms, and/or lower EPT and/or higher Biotic Index (Table 5). Crouch Branch was by far the most perturbed of the three streams, with only 19 taxa collected, none of which were the generally more sensitive EPT taxa. The macroinvertebrate community of Crouch Branch was overwhelmingly dominated by Chironomini chironomids [primarily Kiefferulus dux (64.64\%) and Chironomus spp. (14.92\%; Tables 4 and 5). Domination by Chironomini is generally considered to be an indication of perturbed conditions. Crouch Branch had a relatively low oxygen concentration at the time of sample retrieval, with a reading of $4.4 \mathrm{mg} / \mathrm{l}$ (Table 2 ). It is possible that reduced oxygen levels 


\begin{tabular}{|c|c|c|c|c|c|c|}
\hline & 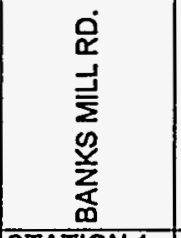 & $\begin{array}{l}\bar{\alpha} \\
0 \\
o \\
o \\
\alpha\end{array}$ & $\begin{array}{l}1 \\
0 \\
8 \\
8 \\
\end{array}$ & $\begin{array}{c}\text { 岕 } \\
\stackrel{0}{0} \\
\frac{\alpha}{\alpha} \\
\frac{\alpha}{\alpha} \\
\end{array}$ & $\begin{array}{l}0 \\
0 \\
0 \\
0 \\
0 \\
\end{array}$ & $\begin{array}{l}\sigma \\
0 \\
0 \\
0 \\
\alpha\end{array}$ \\
\hline & STATION 1 & STATION 4 & STATION 33 & STATION 32 & STATION 13 & STATION 18 \\
\hline TOTAL\# TAXA & 43 & 45 & 42 & 44 & 52 & 43 \\
\hline MEAN TAXAVSAMPLER & 20.0 & 23.8 & 22.2 & 24.0 & 26.8 & 22.4 \\
\hline TOTAL NO. ORGANISMS & 589 & 727 & 398 & 1234 & 1039 & 516 \\
\hline DENSITY (NO.MM2) & 658.1 & 812.3 & 444.7 & 1378.8 & 1160.9 & 576.5 \\
\hline EPT & 17 & 15 & 12 & 15 & 16 & 14 \\
\hline BIOTIC INDEX & 6.22 & 6.10 & 5.93 & 6.66 & 6.50 & 6.11 \\
\hline SC/CF & 0.14 & 0.11 & 0.71 & 0.18 & 0.10 & 0.22 \\
\hline BIOMASS (G/M2) & 0.1321 & 0.8470 & 0.1022 & 0.1789 & 0.2867 & 0.0296 \\
\hline \multicolumn{7}{|l|}{ TAXA \% COMPOSITION } \\
\hline Ephemeroptera & 4.41 & 1.65 & 8.29 & 4.3 & 1.73 & 3.88 \\
\hline Plecoptera & 2.89 & 9.22 & 4.27 & 2.43 & 3.46 & 4.65 \\
\hline Trichoptera & 8.66 & 6.74 & 7.54 & 6.81 & 4.62 & 4.07 \\
\hline Coleoptera & 1.7 & 1.93 & 15.58 & 2.27 & 2.31 & 8.53 \\
\hline Odonata & 0.00 & 0.28 & 0.00 & 0.00 & 0.00 & 0.00 \\
\hline Megaloptera & 0.34 & 0.14 & 0.50 & 0.08 & 0.48 & 0.58 \\
\hline Hemiptera & 0.00 & 0.00 & 0.00 & 0.00 & 0.00 & 0.00 \\
\hline Lepidoptera & 0.00 & 0.00 & 0.00 & 0.16 & 0.10 & 0.19 \\
\hline Other Diptera & 9.85 & 4.68 & 6.78 & 8.02 & 4.52 & 5.43 \\
\hline Tanypodinae & .1 .53 & 6.05 & 3.7. & 1.70 & 4.81 & 3.10 \\
\hline Tanytarsini & 25.98 & 19.53 & 8.79 & 6.89 & 12.03 & 9.11 \\
\hline Orthocladiinae & 40.75 & 37.00 & 33.67 & 56.97 & 47.55 & 50.19 \\
\hline Chironomini & 3.40 & 12.79 & 10.80 & 10.29 & 18.38 & 9.88 \\
\hline Pseudochiromomini & 0.00 & 0.00 & 0.00 & 0.00 & 0.00 & 0.00 \\
\hline Dlamesinae & 0.00 & 0.00 & 0.00 & 0.00 & 0.00 & 0.00 \\
\hline Oligochaeta. & 0.00 & 0.00 & 0.00 & 0.00 & 0.00 & 0.00 \\
\hline Hirudinea & 0.00 & 0.00 & 0.00 & 0.00 & 0.00 & 0.00 \\
\hline Gastropoda & 0.00 & 0.00 & 0.00 & 0.00 & 0.00 & 0.19 \\
\hline Pelecypoda & 0.00 & 0.00 & 0.00 & 0.00 & 0.00 & 0.00 \\
\hline Isopoda & 0.00 & 0.00 & 0.00 & 0.00 & 0.00 & 0.00 \\
\hline Amphipoda & 0.00 & $0 . \infty$ & 0.00 & 0.00 & 0.00 & 0.00 \\
\hline Hydracarina & 0.51 & 0.00 & 0.00 & 0.08 & 0.00 & 0.19 \\
\hline Decapoda & 0.00 & 0.00 & 0.00 & 0.00 & 0.00 & 0.00 \\
\hline TOTAL & 100.02 & 100.01 & 99.99 & 100 & 99.99 & 99.99 \\
\hline \multicolumn{7}{|l|}{ FUNC. \% COMPOSITION } \\
\hline Collector-Gatherers & 71.31 & 67.95 & 68.84 & 76.09 & 77.09 & 73.64 \\
\hline Collector-Filterers & 19.69 & 10.45 & 11.31 & 15.48 & 11.36 & 13.18 \\
\hline Predators & 4.93 & 16.37 & 10.05 & 4.54 & 8.85 & 8.14 \\
\hline Scrapers & 2.72 & 1.10 & 8.04 & 2.76 & 1.15 & 2.91 \\
\hline Shredders & 1.36 & 4.13 & 1.76 & 0.81 & 1.35 & 1.74 \\
\hline Piercer-Herbivores & 0.00 & 0.00 & 0.00 & 0.32 & 0.19 & 0.39 \\
\hline TOTAL & 100.01 & 100.00 & 100.00 & 100.00 & 99.99 & 100.00 \\
\hline \multicolumn{7}{|l|}{ BIOMASS \% COMPOSITION } \\
\hline Collector-Gatherers & 5.75 & 1.57 & 33.99 & 9.57 & 10.29 & 11.32 \\
\hline Collector Filterers & 3.38 & 0.84 & 4.81 & 11.37 & 3.23 & 3.02 \\
\hline Predalors & 87.65 & 95.90 & 31.37 & $41 . \overline{39}$ & 74.59 & 48.68 \\
\hline Scrapers & 3.21 & 0.61 & 21.53 & 11.37 & 1.91 & 12.45 \\
\hline Shredders & 0.00 & 1.08 & 8.31 & 25.48 & 9.59 & 24.53 \\
\hline Piercer-Herbivores & 0.00 & 0.00 & 0.00 & 0.81 & 0.39 & 0.00 \\
\hline TOTAL & 99.99 & 100.00 & 100.01 & 99.99 & 100.00 & 100.00 \\
\hline
\end{tabular}


TABLE 4. RELATIVE ABUNDANCE (\%) OF COMMON MACROINVERTEBRATE TAXA IN SRS STREAMS JULY-AUGUST 1993

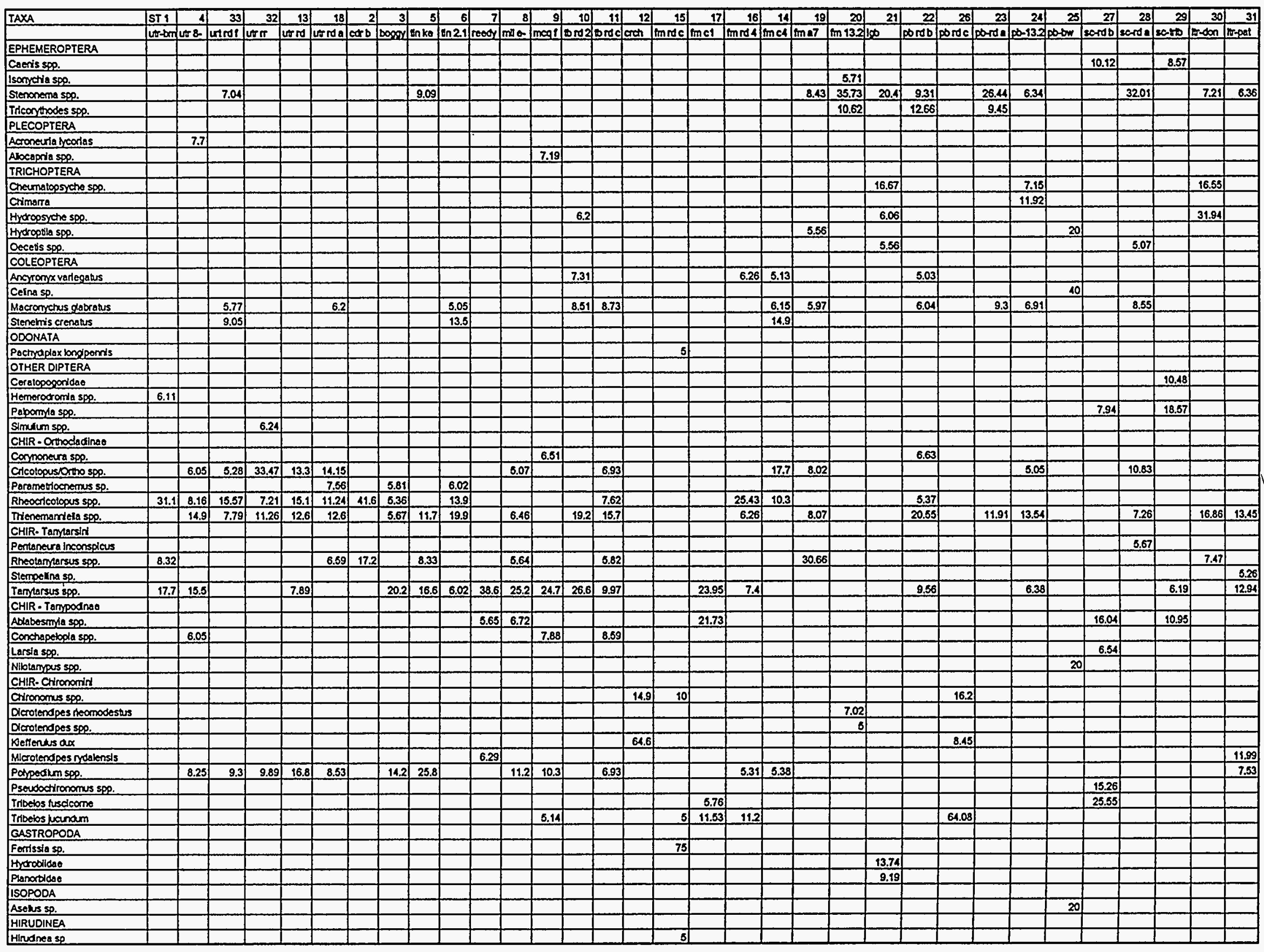




\begin{tabular}{|c|c|c|c|c|c|c|c|c|c|c|}
\hline & 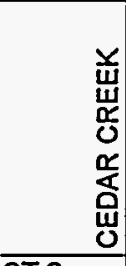 & 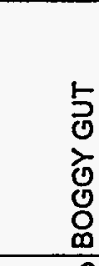 & 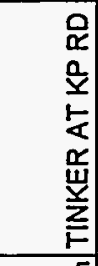 & 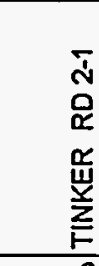 & 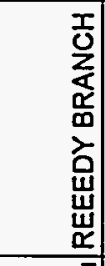 & 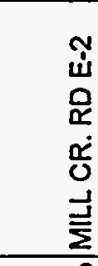 & 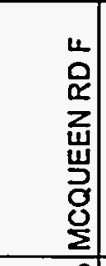 & 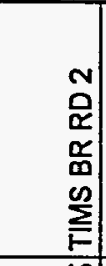 & 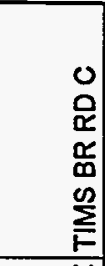 & 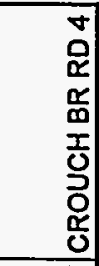 \\
\hline & $\overline{\text { ST } 2}$ & 3 & 5 & $\overline{6}$ & 7 & $\overline{8}$ & 9 & 10 & 11 & 12 \\
\hline TOTAL\# TAXA & 47 & 57 & 53 & 46 & 52 & $\overline{63}$ & 35 & 38 & 48 & 19 \\
\hline MEAN TAXASAMPLER & 25.2 & 26.8 & 24.0 & 27.2 & 28.4 & 33.2 & 17.0 & 20.2 & 27.0 & 5.6 \\
\hline TOTAL NO. ORGANISMS & 963 & 653 & 924 & 1030 & 938 & 1578 & 292 & 1081 & 722 & 181 \\
\hline DENSITY (NO.M2) & 1076 & 729.6 & 1032.4 & 1150.8 & 1048 & 1763.1 & 326.3 & 1207.8 & 806.7 & 202.2 \\
\hline EPT & 15 & 19 & 16 & 12 & 11 & 15 & 4) & 4 & 8 & 0 \\
\hline BIOTIC INDEX & 6.73 & 6.04 & 6.07 & 6.00 & 6.07 & 6.48 & 6.60 & 6.23 & 6.25 & 9.47 \\
\hline $\mathrm{SC} / \mathrm{CF}$ & 0.06 & 0.26 & 0.70 & 0.20 & 0.82 & 0.21 & 7.00 & 0.00 & 0.27 & 0.00 \\
\hline BIOMASS (G/M2) & 0.0293 & 0.1751 & 0.5209 & 0.2716 & 0.0713 & 0.0904 & 0.0374 & 0.1360 & 0.1578 & 0.0207 \\
\hline \multicolumn{11}{|l|}{ TAXA \% COMPOSITION } \\
\hline Ephemeroptera & 3.22 & 2.76 & 13.42 & 2.91 & 4.9 & 6.46 & 0.68 & 0 & 4.57 & \\
\hline Plecoptera & 0.31 & 3.37 & 0 & 3.4 & 0.75 & 0 & 7.19 & 0 & 3.05 & 0 \\
\hline Trichoptera & 9.03 & 2.14 & 6.28 & 0.97 & 4.26 & 3.99 & 1.71 & 8.05 & 2.49 & \\
\hline Coleoptera & 1.35 & 12.25 & 2.71 & 18.84 & 6.08 & 1.08 & 1.02 & 17.30 & 11.91 & 1.10 \\
\hline Odonata & 0.21 & 0.31 & 0.11 & 0.00 & 0.21 & 0.38 & 3.08 & 0.18 & 0.28 & 1.10 \\
\hline Megaloptera & 0.10 & 1.07 & 1.19 & 0.10 & 0.21 & 0.00 & 0.68 & 0.00 & 0.69 & 0.00 \\
\hline Hemiptera & 0.00 & 0.00 & 0.00 & 0.00 & 0.00 & 0.00 & 0.00 & 0.00 & 0.14 & 0.55 \\
\hline Lepidoptera & 0.00 & 0.00 & 0.00 & 0.00 & 0.00 & 0.00 & 0.00 & 0.00 & 0.00 & 0.00 \\
\hline Other Diptera & 5.19 & 3.68 & 0.76 & 4.66 & 1.71 & 2.22 & 4.11 & 278 & 1.25 & 1.66 \\
\hline Tanypodinae & 1.35 & 5.36 & 1.52 & 4.76 & 9.49 & 12.29 & 18.84 & 6.57 & 9.28 & 2.21 \\
\hline Tanytarsini & 20.67 & 24.96 & 24.89 & 10.10 & 42.96 & 33.02 & 24.66 & 31.36 & 17.31 & 5.52 \\
\hline Orthocladilinae & 48.29 & 23.58 & 19.81 & 46.21 & 6.50 & 17.87 & 8.56 & 26.83 & 38.23 & 0.55 \\
\hline Chironomini & 7.68 & 20.37 & 28.03 & 6.99 & 21.54 & 22.56 & 29.10 & 4.81 & 10.66 & 86.19 \\
\hline Pseudochiromominl & 0.00 & 0.00 & 0.00 & 0.10 & 0.11 & 0.00 & 0.00 & 0.00 & 0.00 & 0.55 \\
\hline Diamesinae & 0.00 & 0.00 & 0.00 & 0.00 & 0.00 & 0.00 & 0.00 & 0.00 & 0.00 & 0.00 \\
\hline Oligochaeta & 2.60 & 0.15 & 0.22 & 0.00 & 0.00 & 0.00 & 0.00 & 0.00 & 0.00 & 0.00 \\
\hline Hirudinea & 0.00 & 0.00 & 0.00 & 0.00 & 0.00 & 0.00 & 0.00 & 0.00 & 0.00 & 0.00 \\
\hline Gastropoda & 0.00 & 0.00 & 0.22 & 0.00 & 1.07 & 0.06 & 0.34 & 0.00 & 0.00 & 0.00 \\
\hline Pelecypoda & 0.00 & 0.00 & 0.22 & 0.00 & 0.11 & 0.00 & 0.00 & 0.00 & 0.00 & 0.00 \\
\hline Isopoda & 0.00 & 0.00 & 0.00 & 0.00 & 0.00 & 0.00 & 0.00 & 0.00 & 0.00 & 0.00 \\
\hline Amphipoda & 0.00 & 0.00 & 0.00 & 0.00 & 0.11 & 0.06 & 0.00 & 2.04 & 0.00 & 0.00 \\
\hline Hydracarina & 0.00 & 0.00 & 0.54 & 0.97 & 0.00 & 0.00 & 0.00 & 0.09 & 0.14 & 0.55 \\
\hline Decapoda & 0.00 & 0.00 & 0.11 & 0.00 & 0.00 & 0.00 & 0.00 & 0.00 & 0.00 & 0.00 \\
\hline TOTAL & 100.00 & 100.00 & 100.03 & 100.01 & 100.01 & 99.99 & 99.97 & 100.01 & 100.00 & 99.98 \\
\hline \multicolumn{11}{|l|}{ FUNC. $\%$ COMPOSITION } \\
\hline Collector-Gatherers & 65.94 & 75.19 & 70.88 & 82.62 & 76.33 & 72.43 & 54.45 & 79.93 & 72.58 & 93.37 \\
\hline Collector-Filterers & 24.09 & 7.04 & 14.07 & 4.95 & 4.26 & 9.19 & 0.34 & 11.19 & 8.17 & 1.10 \\
\hline Predators & 2.28 & 10.26 & 4.33 & 9.13 & 12.05 & 15.15 & 25.34 & 8.33 & 12.60 & 5.52 \\
\hline Scrapers & 1.45 & 1.84 & 9.85 & 0.97 & 3.52 & 1.96 & 2.40 & 0.00 & 2.22 & 0.00 \\
\hline Shredders & 4.57 & 5.67 & 0.87 & 2.33 & 3.73 & 1.08 & 17.47 & 0.56 & 4.43 & 0.00 \\
\hline Plercer-Herbivores & 1.66 & 0.00 & 0.00 & 0.00 & 0.11 & 0.19 & 0.00 & 0.00 & 0.00 & 0.00 \\
\hline TOTAL & 99.99 & 100.00 & 100.00 & 100.00 & 100.00 & 100.00 & 100.00 & 100.01 & 100.00 & 99.99 \\
\hline \multicolumn{11}{|l|}{ BIOMASS \% COMPOSITION } \\
\hline Collector-Gathere & 40.84 & 25.69 & 4.80 & 46.85 & 57.37 & 38.81 & 27.25 & 8603 & 3683 & 88.65 \\
\hline Collector Filterers & 26.34 & 3.37 & 6.95 & 0.62 & \begin{tabular}{l|l}
9.72 \\
\end{tabular} & 15.45 & 0.00 & 7.15 & 3.61 & 1.08 \\
\hline Predators & 23.28 & 55.50 & 79.02 & 41.22 & 10.66 & 27.07 & 33.23 & 5.67 & 36.19 & 10.27 \\
\hline Scrapers & 0.38 & 5.66 & 8.77 & 0.70 & 12.07 & 14.46 & 5.99 & 0.00 & 7.08 & 0.00 \\
\hline Shredders & 8.78 & 9.78 & 0.45 & 10.61 & 9.87 & 3.71 & 33.53 & 1.15 & 16.29 & 0.00 \\
\hline Piercer-Herbivores & 0.38 & 0.00 & 0.00 & 0.00 & 0.31 & 0.49 & 0.00 & 0.00 & 0.00 & 0.00 \\
\hline TOTAL & 100.00 & 100.00 & 99.99 & 100.00 & 100.00 & 99.99 & 100.00 & 100.00 & 100.00 & 100.00 \\
\hline
\end{tabular}


were responsible, at least in part, for the observed perturbation. In addition to receiving SRS effluents, both Crouch Branch and McQueen's Branch were subject to high levels of total suspended solids and scouring during construction of the DWPF. Therefore, the observed perturbation may be due, at least in part, to DWPF construction activities, rather than to present operational activities. The macroinvertebrate community of Tim's Branch improved in a downstream direction, with the total number of taxa collected increasing from 38 near Road 2 to 48 near its confluence with Upper Three Runs (Table 5). The mean number of taxa and number of EPT taxa also increased substantially, although density of organisms declined (Table 5). Tim's Branch receives discharges from $A$ and $M$ Areas, and has been the site of a long-term macroinvertebrate sampling program supported by $M$-Area to examine the effects of $M$ Area discharges on the stream (Specht et al., 1987; Enwright Environmental, 1991). These studies found that a pond upstream from the M-Area discharge usually discharges anoxic water, which precludes the presence of most species of macroinvertebrates. As the water flows downstream, water quality gradually increases, as the oxygen concentrations in the water increase. Therefore, although portions of Tims' Branch appear to be perturbed, the perturbation may be due to naturally occurring low levels of oxygen, rather than to discharges from $A$ and $M$ Areas.

The remainder of the tributaries of Upper Three Runs that were sampled showed no evidence of perturbation. The largest number of taxa in these tributaries was collected in Mill Creek (63), while the fewest were collected in Tinker Creek (46; Table 5). EPT was relatively high, ranging from 11 to 16 (Table 5). Dominant taxa in most of the tributaries included the orthoclad chironomids, Rheocricotopus spp. and Thiemanellia spp., the tanytarsine chironomids Rheotanytarsus spp. and Tanytarsus spp., the Tanypodinae chironomid, Ablabesmyia spp., and the Chironomini chironomid, Polypedilum spp (Table 4). Most.of these taxa were also among the most common taxa collected in Upper Three Runs.

\section{Fourmile Branch Macroinvertebrates}

Fourmile Branch receives effluents from 16 NPDES outfalls in $F, H$, and $C$ Areas and Central Shops, and groundwater inputs from the old $F$ and $H$ Area seepage basins and portions of the Burial Ground. Until 1985, the portion of Fourmile Branch downstream of Road 3 received cooling water from $C$ Reactor and was subject to extremely high temperatures and flows. Six locations were sampled in Fourmile Branch; five were located upstream from the reactor outfall and one (Road A-13.2) was located in the portion of the stream that had been thermally impacted.

Three of the six stations (Road C-4, Road A-7 and Road A-13.2 all had relatively high numbers of taxa present (46 to 52) and mean number of taxa per sampler (20.2 to 32.2; Table 6). Two of the three stations had relatively high EPT (Road A-7, 15; Road A-13.2, 17; Table 6). Two of the remaining three stations (Road E-1 and Road C-4) had somewhat lower values for these parameters (Table 6), possibly indicating some degree of perturbation.

At most stations in Fourmile Branch, the macroinvertebrate community was dominated by chironomids (Table 6). At Road E-1, Tanypodinae (primarily Ablabesmyia spp.) was the most dominant group, followed by Chironomini (mostly Tribelos spp.; Table 4)., At 


\begin{tabular}{|c|c|c|c|c|c|c|}
\hline & 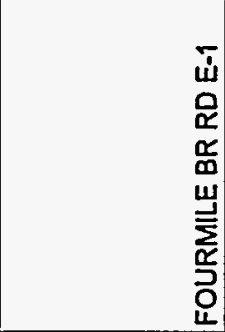 & 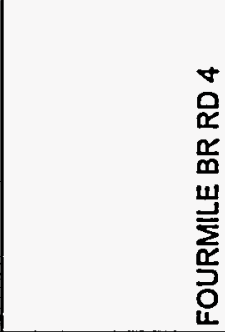 & 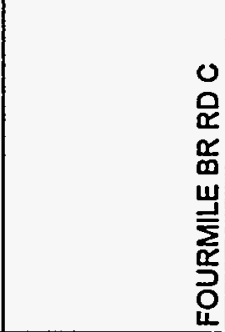 & 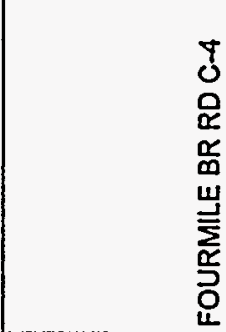 & 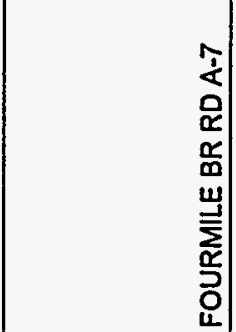 & 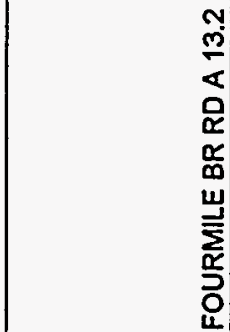 \\
\hline & STATION 17 & STATION 16 & STATION 15 & STATION 14 & STATION 19 & STATION 20 \\
\hline TOTAL \#TAXA & 30 & 46 & - & 36 & 49 & 52 \\
\hline MEAN TAXAVSAMPLER & 16.2 & 20.2 & 1.6 & 17.6 & 32.2 & 27.8 \\
\hline TOTAL NO. ORGANISMS & 451 & 527 & 20 & 390 & 1709 & 1139 \\
\hline DENSITY (NO./M2) & 503.9 & 588.8 & 22.3 & 435.8 & 1909.5 & 1272.6 \\
\hline EPT & 5 & 7 & 0 & 8 & 15 & 17 \\
\hline BIOTIC INDEX & 6.58 & 6.85 & 7.37 & 6.78 & 6.04 & 5.10 \\
\hline SC/CF & 0.33 & 1.04 & * & 0.58 & 0.25 & 3.58 \\
\hline BIOMASS (G/M2) & 0.0145 & 0.0253 & 0.0013 & 0.1955 & 0.0278 & 0.6950 \\
\hline \multicolumn{7}{|l|}{ TAXA \% COMPOSITION } \\
\hline Ephemeroptera & 9.76 & 3.23 & 0.00 & 1.54 & 13.17 & 55.75 \\
\hline Plecoptera & 0.00 & 0.00 & 0.00 & 0.00 & 0.12 & 0.00 \\
\hline Trichoptera & 0.89 & 2.85 & 0.00 & 4.87 & 11.88 & 7.55 \\
\hline Coleoptera & 1.33 & 7.78 & 0.00 & 26.15 & 8.31 & 7.99 \\
\hline Odonata & 3.33 & 4.17 & 5.00 & $0 . \overline{77}$ & 0.23 & 0.44 \\
\hline Megaloptera & 0.44 & 0.76 & 0.00 & 1.03 & 0.47 & 0.18 \\
\hline Hemiptera & 0.00 & 0.00 & 0.00 & 0.00 & 0.00 & 0.00 \\
\hline Lepldoptera & 0.00 & 0.00 & 0.00 & 0.00 & 0.00 & 0.00 \\
\hline Other Diptera & 2.22 & 3.80 & 0.00 & 4.36 & 3.04 & 4.04 \\
\hline Tanypodinae & 31.04 & 5.69 & 0.00 & 8.21 & 2.11 & 3.69 \\
\hline Tanytarsini & 23.95 & 10.25 & 0.00 & 1.79 & 31.30 & 2.63 \\
\hline Orthocladiinae & 1.11 & 33.78 & 0.00 & 34.62 & 25.57 & 4.83 \\
\hline Chironomini & 25.94 & 25.05 & 15.00 & 15.64 & 0.94 & $12.7 \overline{3}$ \\
\hline Pseudochirornomini & 0.00 & 0.00 & 0.00 & 0.00 & 0.00 & 0.00 \\
\hline Dlamesinae & 0.00 & 0.00 & 0.00 & 0.00 & 0.06 & 0.00 \\
\hline Ollgochaeta & 0.00 & 0.38 & 0.00 & 0.00 & 0.23 & 0.00 \\
\hline Hirudinea & 0.00 & 0.19 & 5.00 & $0 . \overline{0}$ & 0.00 & 0.00 \\
\hline Gastropoda & 0.00 & 1.90 & 75.00 & 0.26 & 0.35 & 0.00 \\
\hline Pelecypoda & 0.00 & 0.00 & 0.00 & 0.51 & 0.00 & 0.18 \\
\hline Isopoda & 0.00 & 0.00 & 0.00 & 0.00 & 0.00 & 0.00 \\
\hline Amphipoda & 0.00 & 0.19 & 0.00 & 0.00 & 0.00 & 0.00 \\
\hline Hydracarina & 0.00 & 0.00 & 0.00 & 0.26 & 2.22 & 0.00 \\
\hline Decapoda & 0.00 & 0.00 & 0.00 & 0.00 & 0.00 & 0.00 \\
\hline TOTAL & 100.01 & 100.02 & 100.00 & 100.01 & 100.00 & 100.01 \\
\hline \multicolumn{7}{|l|}{ FUNC. \% COMPOSITION } \\
\hline Collector-Gatherers & 61.42 & 77.23 & 15.00 & 74.87 & 41.14 & 42.05 \\
\hline Collector-Filterers & 0.67 & 4.74 & 0.00 & 3.08 & 35.69 & 10.01 \\
\hline Predators & 37.03 & 12.71 & 10.00 & 16.41 & 8.25 & 10.18 \\
\hline Scrapers & 0.22 & 4.93 & 75.00 & 1.79 & 8.78 & 35.82 \\
\hline Shredders & 0.67 & 0.38 & 0.00 & 3.85 & 0.23 & 0.79 \\
\hline Piercer-Herbivores & 0.00 & 0.00 & 0.00 & 0.00 & 5.91 & $\mathbf{1 . 1 4}$ \\
\hline TOTAL & 100.01 & 99.99 & 100.00 & 100.00 & 100.00 & 99.99 \\
\hline \multicolumn{7}{|l|}{ BIOMASS \% COMPOSITION } \\
\hline Collector-Gatherers & 51.54 & 33.63 & 0.00 & 29.20 & 32.94 & 21.38 \\
\hline Collector Filterers & 0.00 & 3.10 & 0.00 & 1.77 & 32.14 & 27.33 \\
\hline Predators & 33.08 & 42.48 & 0.00 & 3.09 & $\because 10.32$ & 17.04 \\
\hline Scrapers & 10.77 & 15.93 & 100.00 & 64.69 & 20.63 & 29.58 \\
\hline Shredders & 4.62 & 4.87 & 0.00 & 1.25 & 1.59 & 2.41 \\
\hline Piercer-Herbivores & 0.00 & 0.00 & 0.00 & 0.00 & 2.38 & 2.25 \\
\hline TOTAL & 100.01 & 100.01 & 100.00 & 100.00 & 100.00 & 99.99 \\
\hline
\end{tabular}

* SC/CF ratio cannot be calcualted when $\mathrm{CF}$ is 0 . 
Road A-7, Tanytarsini (primarily Rheotanytarsus spp.) were the most abundant group of macroinvertebrates collected (Tables 4 and 6). Orthoclad chironomids were conspicuously rare at Road E-1, accounting for only $1.11 \%$ of the organisms collected (Table 6). The dissolved oxygen concentration at Road E-1 at the time of sample collection was $4.0 \mathrm{mg} / \mathrm{l}$ (Table 2). It is likely that low dissolved oxygen levels were responsible for the observed pertubation at Road E-1. At Road 4 and Road C-4, orthoclads were the most common group of chironomids collected, comprising 33.78 and $34.62 \%$ of the macroinvertebrates collected at these two stations, respectively (Table 6). The most common orthoclads were Rheocricotopus spp., Cricotopus spp., and Thienemanniella spp (Table 4). At Road A-7, these genera of orthoclads were also abundant, but the Tanytarsini midges (mostly Rheotanytarsus spp.) were slightly more abundant. At Road A-13.2, Ephemeroptera were by far the most abundant group, accounting for $55.75 \%$ of the macroinvertebrates collected (Table 6 ). Common species of mayflies at this station included Stenonema spp. (35.73\%), Tricorythodes spp. (10.62\%), and /sonychia spp. (5.71\%; Table 4). Of the 33 stations that were sampled, Road A-13.2 was the only station where Isonychia was collected. Isonychia is a collector-filterer, feeding primarily on suspended organic matter. Filter-feeders are often abundant downstream of reservoirs, where they feed on suspended algae. At both Road A-13.2 and Road A-7, filter-feeders were very common, accounting for 29.7 and $35.69 \%$ of the organisms collected (Table 6). Beaver ponds upstream from these locations, where water can pool, are very likely are the source of the abundant suspended organic matter at these locations. Similar abundances of collector-filterers were also observed downstream from Par Pond and just upstream from the Pen Branch delta.

Collections from Road $\mathrm{C}$ indicate that the macroinvertebrate community at that location was extremely depauperate, with only five taxa collected (Table 6). The density of macroinvertebrates at Road $\mathrm{C}$ was also extremely low (22.3 organisms $/ \mathrm{m}^{2}$; Table 6). The dissolved oxygen in Fourmile Branch at Road C was only $0.8 \mathrm{mg} / \mathrm{l}$ at the time of sample retrieval (Table 2). Therefore, it appears that low dissolved oxygen levels were responsible for the depauperate macroinvertebrate community at this station.

The macroinvertebrate data collected from six locations in Fourmile Branch show longitudinal trends with respect to most of the parameters that were measured. In general, the quality of the stream appears to improve in a downstream direction. The uppermost two stations that were sampled (Road C and Road E-1) both had low levels of dissolved oxygen (Table 2). While the low dissolved oxygen is obviously responsible for some of the perturbation in Fourmile Branch, it is also possible that the portions of the creek in the vicinity of $F$ and $H$ Areas are being impacted by effluent discharges from $F$ and $H$ Areas and/or by contaminated groundwater that outcrops near the stream.

\section{Pen Branch/Indian Grave Branch Macroinvertebrates}

Pen Branch and its tributary, Indian Grave Branch receive effluents from 7 NPDES outfalls in K Area and Central Shops. Until 1989, Indian Grave Branch received cooling water from K Reactor and both Indian Grave Branch and the portion of Pen Branch downstream from its confluence with Indian Grave Branch were subject to extremely 
high temperatures and flows. Macroinvertebrates were sampled at Indian Grave Branch at Road B and at five locations in Pen Branch.

The station in Indian Grave Branch and three of the five stations in Pen Branch (Road $B$, Road $A$ and Road A-13.2 all had relatively high numbers of taxa present (40 to 62), high mean number of taxa per sampler (22.0 to 34.2), high EPT (12 to 20) and high densities ( 1106.1 to 2765.4 organisms $/ \mathrm{m}^{2}$; Table 7 ). Biomass at these four stations was also relatively high, ranging from 0.1339 to $0.4648 \mathrm{~g} / \mathrm{m}^{2}$ (Table 7). The macroinvertebrate community at these four stations was dominated by Ephemeroptera (23.57 to $38.74 \%$ ) and Trichoptera (2.77 to $39.70 \%$; Table 7 ). Orthoclad chironomids (15.14 to $36.58 \%$ ) and Coleoptera (7.11 to $11.24 \%$ ) were also abundant in Pen Branch, but not in Indian Grave Branch, where Gastropoda was much more abundant than in Pen Branch, accounting for $24.65 \%$ of the organisms collected, as compared to less than $2 \%$ of the organisms collected at the Pen Branch stations. Dominant taxa included the mayflies, Stenonema spp. and Triconthodes spp.; the caddisflies, Cheumatopsyche spp. and Chimarra spp.; the beetle Macronychus glabratus; the orthoclad, Thienemanniella spp., and in Indian Grave Branch, snails in the families of Hydrobiidae (13.74\%) and Planorbidae (9.19\%; Table 4).

The macroinvertebrate communities of the remaining two stations in Pen Branch (Road $C$ and Pen Branch Boardwalk) were very different, with fewer total taxa (12 and 4 taxa for Road $C$ and the Boardwalk, respectively), mean taxa per sampler (5.2 and 1.0, respectively), greatly reduced densities of organisms (158.7 and 5.59 organisms $/ \mathrm{m}^{2}$, respectively), and very low biomass $\left(0.0118 \mathrm{~g} / \mathrm{m}^{2}\right.$ at Road $\mathrm{C}$ and $0.0008 \mathrm{~g} / \mathrm{m}^{2}$ at the Pen Branch Boardwalk; Table 7). No EPT were collected at Road C and just one EPT species was collected at the Boardwalk (Table 7). The macroinvertebrate community at Road C was overwhelmingly dominated by Chironomini chironomids (95.07\%; primarily Tribelos jucundum); while at the Boardwalk, the five organisms that were collected consisted of two beetles (Celina sp.), one caddisfly (Hydroptila sp.), one Tanypodinae chironomid (Nilotanypus sp.) and one isopod (Asellus sp.; Table 4). The macroinvertebrate data from these two stations clearly indicate that these stations were perturbed at the time of sample collection. An examination of the water chemistry data indicate that both of these stations had very low concentrations of dissolved oxygen, with values of 2.1 and $0.2 \mathrm{mg} / \mathrm{l}$ measured at Road $\mathrm{C}$ and the Boardwalk, respectively (Table 2). The low levels of dissolved oxygen were undoubtedly.responsible for the observed perturbation at these two stations.

\section{Steel Creek Macroinvertebrates}

Steel Creek and its tributary, Meyer's Branch receive effluent from 9 NPDES outfalls in $L$ and $P$. Areas and the Railroad Yard (CY Area). Macroinvertebrates were sampled in Steel Creek at Road $B$, which is just upstream from $L$ Lake, and at Road $A$, which is approximately $1.5 \mathrm{~km}$ downstream from the L-Lake dam. The macroinvertebrate community at Road $B$ appeared to be somewhat perturbed, as evidenced by the fewer total taxa (29 vs. 49 ) and mean number of taxa (17.4 vs. 25.8), lower density of organisms (717.3 vs. 1124 organisms $\left./ \mathrm{m}^{2}\right)$, lower EPT (7 vs. 18) and lower biomass $\left(0.0570 \mathrm{vs} 0.1153 \mathrm{~g} / \mathrm{m}^{2}\right)$ than at Road A (Table 8). However, an examination of the physico-chemial data for the location sampled at Road $B$ indicates that the width at the 
TABLE 7. PEN BRANCH AND INDIAN GRAVE BRANCH MACROINVERTEBRATES, JULY-AUGUST 1993

\begin{tabular}{|c|c|c|c|c|c|c|}
\hline & 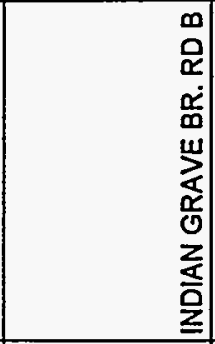 & 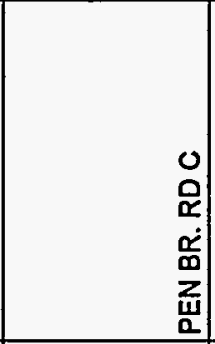 & $\begin{array}{l}\infty \\
0 \\
0 \\
\alpha \\
0 \\
z_{u} \\
a\end{array}$ & 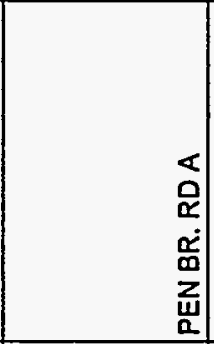 & 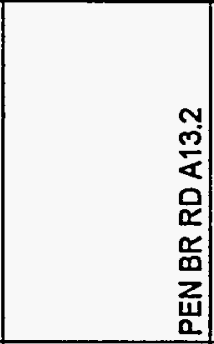 & 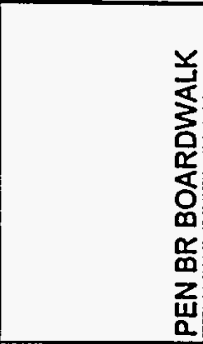 \\
\hline & STATION 21 & STATION 26 & STATION 22 & STATION 23 & STATION 24 & STATION 25 \\
\hline TOTAL \# TAXA & 40 & 12 & 53 & 62 & 47 & 4 \\
\hline MEAN TAXA/SAMPLER & 22.0 & 5.2 & 26.8 & 31.6 & 34.2 & 1.0 \\
\hline TOTAL NO. ORGANISMS & 990 & 142 & 1192 & 1301 & 2475 & 5 \\
\hline DENSITY (NO./M2) & 1106.1 & 158.7 & 1331.8 & 1453.6 & 2765.4 & 5.59 \\
\hline EPT & 15 & 0 & 12 & 20 & 15 & 1 \\
\hline BIOTIC INDEX & 5.44 & 7.49 & 5.76 & 5.17 & 5.58 & 7.32 \\
\hline SC/CF & 1.52 & $\div$ & 2.41 & 2.67 & 0.24 & $\div$ \\
\hline BIOMASS (G/M2) & 0.1826 & 0.0118 & 0.1339 & 0.1962 & 0.4648 & 0.0008 \\
\hline \multicolumn{7}{|l|}{ TAXA \% COMPOSITION } \\
\hline Ephemeroptera & 24.65 & 0.00 & 23.57 & 38.74 & 16.77 & 0.00 \\
\hline Plecoptera & 0.00 & 0.00 & 0.08 & 0.08 & 0.08 & 0.00 \\
\hline Trichoptera & 39.70 & 0.00 & 2.27 & 18.06 & 28.00 & 20.00 \\
\hline Coleoptera & 0.51 & 0.00 & 11.24 & 10.33 & 7.11 & 40.00 \\
\hline Odonata & 0.61 & 0.00 & 1.43 & 1.46 & 0.04 & 0.00 \\
\hline Megaloptera & 0.10 & 0.00 & 0.76 & 0.61 & 4.61 & 0.00 \\
\hline Hemlptera & 0.00 & 0.00 & 0.00 & $0 . \infty$ & 0.00 & 0.00 \\
\hline Lepidoptera & 0.30 & 0.00 & 0.00 & 0.00 & 0.00 & 0.00 \\
\hline Other Diptera & 1.92 & 1.41 & 1.01 & 0.38 & 0.93 & 0.00 \\
\hline Tanypodinae & 5.15 & 1.41 & 7.55 & 3.69 & 4.65 & 20.00 \\
\hline Tanytarsini & 0.71 & 1.41 & 10.74 & 5.61 & 8.93 & 0.00 \\
\hline Orthocladiinae & 1.31 & 0.70 & 36.58 & 15.14 & 23.03 & 0.00 \\
\hline Chironomini & 0.40 & 95.07 & 3.44 & 3.54 & 5.17 & 0.00 \\
\hline Pseudochirornomini & 0.00 & 0.00 & 0.00 & 0.08 & 0.00 & 0.00 \\
\hline Diamesinae & 0.00 & 0.00 & 0.00 & 0.00 & 0.04 & 0.00 \\
\hline Oligochaeta & 0.00 & 0.00 & 0.00 & 0.00 & 0.00 & 0.00 \\
\hline Hirudinea & 0.00 & 0.00 & 0.00 & 0.00 & 0.00 & 0.00 \\
\hline Gastropoda & 24.65 & 0.00 & 0.76 & 1.69 & 0.20 & 0.00 \\
\hline Pelecypoda & 0.00 & 0.00 & 0.25 & 0.46 & 0.00 & 0.00 \\
\hline Isopoda & 0.00 & 0.00 & 0.00 & 0.00 & 0.00 & 20.00 \\
\hline Amphipoda & 0.00 & 0.00 & 0.00 & 0.00 & 0.00 & 0.00 \\
\hline Hydracarina & 0.00 & 0.00 & 0.34 & 0.08 & 0.44 & 0.00 \\
\hline Decapoda & 0.00 & 0.00 & 0.00 & 0.00 & 0.00 & 0.00 \\
\hline TOTAL & 100.01 & 100.00 & 100.02 & 100.00 & 100.00 & 100.00 \\
\hline \multicolumn{7}{|l|}{ FUNC. \% COMPOSITION } \\
\hline Collector-Gatherers & 6.57 & 96.48 & 73.91 & 44.73 & 51.80 & 20.00 \\
\hline Collector-Filterers & 29.70 & 0.00 & 4.28 & 10.61 & 26.91 & 0.00 \\
\hline Predators & 11.92 & 2.82 & 11.24 & 10.99 & 11.31 & 60.00 \\
\hline Scrapers & 45.05 & 0.00 & 10.32 & 28.36 & 6.59 & 0.00 \\
\hline Shredders & 0.00 & 0.70 & 0.16 & 1.31 & 0.36 & 0.00 \\
\hline Plercer-Herbivores & 6.77 & 0.00 & 0.08 & 4.00 & 3.03 & 20.00 \\
\hline TOTAL & 100.01 & 100.00 & 99.99 & 100.00 & 100.00 & 100.00 \\
\hline \multicolumn{7}{|l|}{ BIOMASS \% COMPOSITION } \\
\hline Collector-Gatherers & 5.50 & 91.51 & 52.92 & 17.94 & 15.05 & 37.50 \\
\hline Collector Filterers & 34.78 & $0 . \infty$ & 10.35 & 15.32 & 18.66 & 0.00 \\
\hline Predators & 11.12 & 6.60 & 13.77 & 32.46 & 53.34 & 50.00 \\
\hline Scrapers & 46.82 & 0.00 & 22.20 & 29.44 & 11.30 & 0.00 \\
\hline Shredders & 0.00 & 1.89 & 0.67 & 3.99 & 0.58 & 0.00 \\
\hline Piercer-Herbivores & 1.77 & 0.00 & 0.08 & 0.85 & 1.07 & 12.50 \\
\hline TOTAL & 99.99 & 100.00 & 99.99 & 100.00 & 100.00 & 100.00 \\
\hline
\end{tabular}

* SC/CF ratio cannot be calculated when CF is 0 . 
TABLE 8. STEEL CREEK AND LOWER THREE RUNS MACROINVERTEBRATES, JULY-AUGUST 1993

\begin{tabular}{|c|c|c|c|c|c|}
\hline & $\begin{array}{l}\infty \\
0 \\
\frac{a}{\alpha} \\
o \\
0 \\
\vec{w} \\
w \\
\omega\end{array}$ & 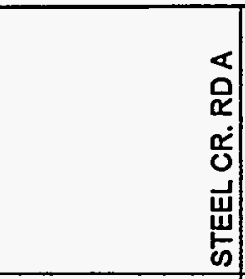 & 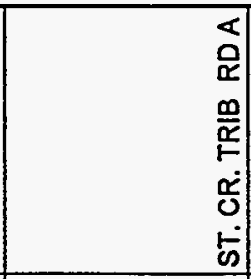 & 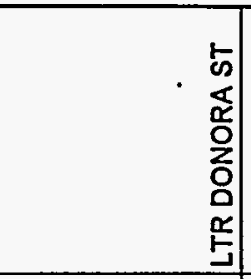 & 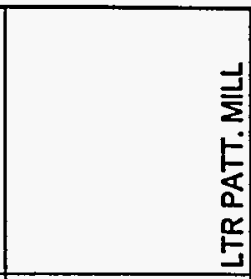 \\
\hline & STATION 27 & STATION 28 & STATION 29 & STATION 30 & STATION 31 \\
\hline TOTAL \# TAXA & 29 & 49 & 39 & 32 & 58 \\
\hline MEAN TAXAVSAMPLER & 17.4 & 25.8 & 15.6 & 21.4 & 32.2 \\
\hline TOTAL NO. ORGANISMS & 642 & 1006 & 210 & 2248 & 1368 \\
\hline DENSITY (NO./M2) & 717.3 & 1124 & 234.6 & 2511.7 & 1528.5 \\
\hline EPT & 7 & 18 & 7 & 12 & 18 \\
\hline BIOTIC INDEX & 6.33 & 5.16 & 6.83 & 5.34 & 5.63 \\
\hline $\mathrm{SC} / \mathrm{CF}$ & 0.00 & 4.46 & 0.57 & 0.12 & 0.90 \\
\hline BIOMASS (G/M2) & 0.0570 & 0.1153 & 0.0178 & 0.3183 & 0.1427 \\
\hline \multicolumn{6}{|l|}{ TAXA \% COMPOSITION } \\
\hline Ephemeroptera & 10.44 & 37.97 & 10.95 & 8.59 & $\overline{12.94}$ \\
\hline Plecoptera & 0.00 & 0.00 & 0.00 & 0.00 & 0.66 \\
\hline Trichoptera & 4.36 & 10.93 & 3.81 & 52.27 & 7.97 \\
\hline Coleoptera & 0.00 & 11.83 & 0.00 & 0.98 & 5.77 \\
\hline Odonata & 1.40 & 0.10 & 1.90 & 0.00 & 0.15 \\
\hline Megaloptera & 0.00 & 0.40 & 0.00 & 1.29 & 0.44 \\
\hline Hemiptera & 0.00 & 0.00 & 0.00 & 0.00 & 0.00 \\
\hline Lepldoptera & 0.00 & 0.30 & 0.00 & 0.00 & 0.00 \\
\hline Other Diptera & 8.72 & 1.49 & 29.05 & 0.89 & 3.66 \\
\hline Tanypodinae & 22.59 & 7.06 & 21.43 & 0.18 & 5.56 \\
\hline Tanytarsini & 3.74 & 2.78 & 7.14 & 7.56 & 22.73 \\
\hline Orthocladilinae & 2.49 & 20.38 & 1.43 & 23.49 & 17.84 \\
\hline Chironomini & 31.00 & 3.58 & 17.14 & 4.45 & 21.71 \\
\hline Pseudochiromomini & 15.26 & 0.00 & 0.00 & 0.00 & 0.00 \\
\hline Dlamesinae & 0.00 & 0.00 & 0.00 & 0.00 & 0.00 \\
\hline Ollgochaeta & 0.00 & 0.00 & 0.00 & 0.00 & 0.00 \\
\hline Hirudinea & 0.00 & 0.00 & 0.95 & 0.00 & 0.00 \\
\hline Gastropoda & 0.00 & 1.69 & 1.43 & 0.00 & 0.22 \\
\hline Pelecypoda & 0.00 & 0.00 & 0.00 & 0.00 & 0.00 \\
\hline Isopoda & 0.00 & 0.00 & 0.00 & 0.00 & 0.00 \\
\hline Amphipoda & 0.00 & 0.00 & 2.38 & 0.00 & 0.00 \\
\hline Hydracarina & 0.00 & 1.49 & 2.38 & 0.31 & 0.29 \\
\hline Decapoda & 0.00 & 0.00 & 0.00 & 0.00 & 0.07 \\
\hline TOTAL & 100 & 100 & 99.99 & 100.01 & 100.01 \\
\hline \multirow{2}{*}{\multicolumn{6}{|c|}{ FUNC. $\%$ COMPOSITION }} \\
\hline & & & & & \\
\hline Collector-Gatherers & 62.93 & 39.86 & 36.67 & 30.56 & 71.20 \\
\hline Collector-Filterers & 3.27 & 8.15 & 3.33 & 58.67 & 8.41 \\
\hline Predators & 32.71 & 14.61 & 56.19 & 2.76 & 11.84 \\
\hline Scrapers & 0.00 & 36.38 & 1.90 & 7.21 & 7.53 \\
\hline Shredders & 0.00 & 0.50 & 0.48 & 0.67 & 0.95 \\
\hline Piercer-Herbivores & 1.09 & 0.50 & 1.43 & 0.13 & 0.07 \\
\hline TOTAL & 100.00 & 100.00 & 100.00 & 100.00 & 100.00 \\
\hline \multicolumn{6}{|l|}{ BIOMASS \% COMPOSITION } \\
\hline Collector-Gatherers & 78.82 & 16.38 & 44.65 & 5.58 & 23.57 \\
\hline \begin{tabular}{|l} 
Collector Filterers \\
\end{tabular} & 5.49 & 10.85 & 11.32 & 51.53 & 17.54 \\
\hline Predators & 15.29 & 10.95 & 35.85 & 33.13 & 25.14 \\
\hline Scrapers & 0.00 & 57.95 & 4.40 & 9.37 & 19.26 \\
\hline Shredders & 0.00 & 1.45 & 0.63 & 0.32 & 5.25 \\
\hline Plercer-Herbivores & 0.39 & 2.42 & 3.14 & 0.07 & 9.24 \\
\hline TOTAL & 99.99 & 100.00 & 99.99 & 100.00 & 100.00 \\
\hline
\end{tabular}


sampling location was 33.53 meters and the discharge velocity was 0 , which indicates that the area that was sampled was probably the very upper end of L-Lake, where water was pooling, rather than in the free-flowing portion of Steel Creek. The macroinvertebrate community at Road $B$ was dominated by the chironomids, Chironomini (31\%), Tanypodinae (22.59\%), and Pseudochironomini (15.26\%), and Ephemeroptera (10.44\%; Table 8). Dominant taxa included the chironomids Tribelos, Pseudochironomus, Ablabesmyia, Larsia, and Palpomyia, and the mayfly Caenis (Table 4). At Road A, the community was dominated by Ephemeroptera ( $37.97 \%$; primarily Stenonema spp.); Orthocladiinae (20.38\%; primarily Cricotopus/Ortho spp. and Thienemanniella spp.), Coleoptera (11.83\%, mostly Macronychus glabratus) and Trichoptera (10.93\%; dominated by Oecetis spp.; Tables 4 and 8 ).

Although it was intended that Meyer's Branch would be sampled at Road 9 as part of this study, the subcontractor that was performing the sampling inadvertently sampled the tributary of Steel Creek that is downstream of Meyer's Branch instead. A total of 39 taxa were collected from this tributary (Table 8 ). The mean number of taxa per sampler was 15.6 (Table 8). The density of organisms was quite low, averaging 234.6 organisms $/ \mathrm{m}^{2}$; Table 8). The EPT was also relatively low, at 7 (Table 8). Dominant groups of taxa included "Other" Diptera (29.05\%; primarily Palpomyia spp. and Ceratopogonidae), Tanypodinae (21.43\%; mostly Ablabesmyia spp and Larsia), Chironomini (17.14\%), and Ephemeroptera (10.95; mostly Caenis sp.; Tables 4 and 8). Of these taxa, Caenis, Ablabesmyia and Palpomyia have all been reported in the literature to have been collected from waters having dissolved oxygen concentrations of less $4 \mathrm{mg} / \mathrm{l}$ (Roback, 1974).

The macroinvertebrate data indicate that this tributary is moderately perturbed, probably due to relatively low levels of dissolved oxygen in the stream. At the time of sampler retrieval, the concentration of dissolved oxygen was $3.7 \mathrm{mg} / \mathrm{l}$ (Table 2) which is lower than many macroinvertebrates can tolerate. Although there is no positive explanation for the low dissolved oxygen, it may be due to beaver activity upstream from the sampling site. Further field investigations are needed to determine the cause of the low dissolved oxygen.

\section{Lower Three Runs Macroinvertebrates}

The portion of Lower Three Runs that is downstream from the Par Pond Dam receives no NPDES discharges directly, but does receive overflow from the Par Pond reservoir. One NPDES outfall discharges to Par Pond via an effluent canal. Reservoirs often impact downstream water quality by altering seston concentrations, and in the case of hypolimnetic discharging reservoirs, altering the temperature regime, oxygen concentrations, and other chemical parameters (iron, manganese, hydrogen sulfide, ammonia, etc.). Two locations were sampled on Lower Three Runs: Donora Station, which is located $1.5 \mathrm{~km}$ downstream from the Par Pond dam, and Patterson Mill, which is located about $8 \mathrm{~km}$ downstream from the dam.

The macroinvertebrate community at Donora Station appears to be strongly influenced by Par Pond, as evidenced by large numbers of collector-filterers $(58.67 \%)$, and relatively high densities of organisms (2511.7 organisms $/ \mathrm{m}^{2} ;$ Table 8$)$. In addition, the total number of taxa (32), mean number of taxa per sampler (21.4) and EPT were all 
somewhat lower at Donora Station that at Patterson Mill (Table 8). At Donora Station, the macroinvertebrate community was numerically dominated by filter-feeding caddisfies (52.27\%; primarily Hydropsyche spp. and Cheumatopsyche spp.) and orthoclad chironomids (23.49\%; primarily Thienemanniella spp.; Tables 4 and 8). Mayflies (mostly Stenonema spp.) were also relatively common, comprising $8.59 \%$ of the organisms collected (Tables 4 and 8 ).

At Patterson Mill, almost twice as many taxa (58) were collected, and the mean number of taxa per sampler (32.2) and EPT (18) were also much higher (Table 8). The community structure also shifted in a downstream direction, with increases in the relative abundance of mayflies, Tanytarsini and Chironomini chironomids, and a large decrease in the relative abundance of caddisflies (from 52.27 to $7.97 \%$; Table 8). Dominant genera at Patterson Mill included Stenonema (6.36\%), Thienemanniella (13.45\%), Tanytarsus (12.94\%), Microtendipes (11.99\%), Polypedilum (7.53\%), and Stempellina (5.26\%; Table 4).

Although the macroinvertebrate community of Lower Three Runs is greatly influenced by Par Pond, the stream maintains a productive and reasonably diverse community. Filter-feeding caddisflies provide an excellent source of food for macroinvertebrate and fish predators. Therefore, even though the macroinvertebrate community is probably very different than it would be without Par Pond had not been built, it still is a viable and diverse community.

\section{CONCLUSIONS}

With a few exceptions, the macroinvertebrate communities of SRS streams are reasonably diverse. The streams which exhibit the greatest taxonomic diversity and appear to be the most unperturbed are the Upper Three Runs tributaries of Mill Creek Tinker Creek and Boggy Gut. Slightly fewer taxa were collected in Upper Three Runs than in these tributaries, but Upper Three Runs still appears to be largely unperturbed. The tributaries of Upper Three Runs that receive SRS runoff and effluents (Tim's Branch, Crouch Branch, and McQueen's Branch are all stressed to some extent, as evidenced by the reduced number of taxa and low numbers of EPT taxa.

The streams that received reactor cooling water and were subjected to extreme thermal regimes through the late 1980's have exhibited remarkable recoveries. In both Pen Branch and Fourmile Branch, the taxonomic richness and EPT richness in the portions of the streams that received thermal discharges are as high or higher than the portions of the stream that did not receive thermal discharges, except for those locations where dissolved oxygen concentrations were low.

Of the 33 locations that were sampled, 6 stations had dissolved oxygen levels that were less than $5 \mathrm{mg} / \mathrm{l}$. Stations with low dissolved oxygen included Crouch Branch at Road 4, Fourmile Branch at Road C, Fourmile Branch at Road E-1, Pen Branch at Road C, Pen Branch at the Boardwalk, and the Steel Creek tributary downstream from Meyer's Branch. Although further field investigations are needed to determine the cause of the reduced oxygen levels at these locations, beaver activity upstream from several of these locations is probably responsible for the low dissolved oxygen concentrations. 
In Fourmile Branch, the macroinvertebrate community appears to improve in a downstream direction. This improvement may be due in part to increases in dissolved oxygen, since two of the three upstream-most locations had dissolved oxygen concentrations of less than $5 \mathrm{mg} / \mathrm{l}$, but it is also possible that the upper stations may be impacted by effluent discharges from $\mathrm{F}$ and/or $\mathrm{H}$ Areas or from contaminated groundwater from $F$ and $H$ areas that outcrops near the stream. Additional sampling is needed to determine if the portions of Fourmile Branch in the vicinity of $F$ and $\mathrm{H}$ areas is truly perturbed, and if so, to identify the stressors.

The macroinvertebrate community of Lower Three Runs near the Par Pond dam is greatly influenced by Par Pond, as evidenced by the high relative abundance of filterfeeders. However, the station near Patterson's Mill, which is approximately $8 \mathrm{~km}$ downstream from the dam appears to be much less altered by discharges from the reservoir.

\section{REFERENCES}

Enwright Environmental, Inc. 1991. Tim's Branch Biological Studies.

Heliovarra, K. and R. Vaisanen. 1993. Insects and Pollution. CRC Press. 393 p.

Merritt, R.W. and K.W. Cummins. 1978. An Introduction to the Aquatic Insects of North America. Kendall/Hunt Publishing Co. 441 p.

Roback, S.S. 1974. Insects (Arthropoda: Insecta); List 7, Species found at dissolved oxygen less than 4 ppm. In: C.W. Hart, Jr. and S.L.H. Fuller, Pollution Ecology of Freshwater Invertebrates. Academic Press, Inc, New York.

South Carolina Department of Health and Environmental Control (SCDHEC). 1993. Water Classifications and Standards, Regulation 61-68.

Specht, W.L., J.B. Pickett, C.F. Muska, W.M. Starkel, M. Giffin, and K.E. Trapp. 1987. Biological and Chemical Assessment of M-Area Process Discharge to Tim's Branch, June 1985-December 1986. DPSP-87-1115. 


\section{APPENDIX A}




\title{
RESULTS OF \\ MACROINVERTEBRATE SAMPLING \\ AT SELECTED \\ SAVANNAH RIVER SITE LOCATIONS. AUGUST 1993 \\ SUBCONTRACT NO. AA86028N
}

\author{
Submitted To: \\ WESTINGHOUSE SAVANNAH RIVER COMPANY \\ Aiken, South Carolina
}

March 1994

(Revised from January 1994)

Submitted By:

SHEALY ENVIRONMENTAL SERVICES, INC. 106 Vantage Point Drive

Cayce, South Carolina 29033

(803) 791-9700

SCDHEC Laboratory Certification No. 26103 
List of Figures

List of Tables

iv

Introduction

Section I

Methods and Materials

Section II

Physicochemical Data

Section III

Macroinvertebrate Data and Summary Statistics

Station:

1) Upper Three Runs Creek @ Banks Mill Road

2) Cedar Creek @ Banks Mill Rd. 25

3) Boggy Gut @ Rd. 781.4 29

4) Upper Three Runs Creek @ Rd. 8-1 34

5) Tinker Creek @ Kennedy's Pond Rd. 38

6) Tinker Creek @ Rd. 2-1 43

7) Reedy Branch @ Rd. 8-1 nr. ATTA Site 47

8) Mill Creek@ Rd. E-2 52

9) McQueen's Branch @ Rd. F 57

10) Tims Branch @ Rd. 2 61

11) Tims Branch @ Rd. C 65

12) Crouch Branch @ Rd. 4

13) Upper Three Runs Creek @ Rd. C 73

14) Four Mile Creek @ Rd. C-4 78

15) Four Mile Creek @ Rd. C 82

16) Four Mile Creek @ Rd 4

17) Four Mile Creek @ Rd E-1 90

18) Upper Three Runs Creek @ Rd. A 94

19) Four Mile Creek @ Rd. A-7 98

20) Four Mile Creek @ Rd. A13.2 . 103

21) Indian Grave Branch @ Rd. B 108

22) Pen Branch @ Rd. B 112

23) Pen Branch @ Rd. A 117

24) Pen Branch @ Rd. A $13.2 \quad$. 122

25) Pen Branch @ Boardwalk 126

26) Pen Branch @ Rd. C 130 


\section{TABLE OF CONTENTS Continued}

27) Steel Creek @ Rd. B

28) Steel Creek @ Rd. A

134

29) Unnamed Tributary of Steel Creek @ Rd. 125

138

30) Lower Three Runs Creek @ Donora

143

31) Lower Three Runs Creek @ Patterson Mill Rd.

32) Upper Three Runs @ RR Bridge

151

33) Upper Three Runs @ Rd. F

156

160

Section IV

Ash Free Dry Weight Data 


\section{LIST OF FIGURES}

Figure

1 Diagram of Hester-Dendy Multiplate Sampler used in this study.

2 Stream profiles of the sampling stations $1-33$.
Page(s)

3

$7-17$ 


\section{LIST OF TABLES}

Table

1 Physicochemical measurements taken in conjunction with the

Page(s) Hester-Dendy macroinvertebratae study at the Savannah River Site, July - August 1993. Measurements were made on sampler retrieval date.

2 Abbreviations and explanation of terms used in the $19-20$ macroinvertebrate data and summary statistics 
MYrom

This report contains the results of the identification, enumeration and summary statistics of the 165 Section 5.2.1 Macroinvertebrate samples collected during August, 1993.

Section I presents the materials and methods used during this study. Section II presents the physicochemical data collected in conjunction with sample retrieval and the stream profiles. Section III contains the data, summary statistics and species lists for the samples arranged by location. The values for the biotic (NCBI) index were obtained from Lenat, 1993 (A biotic index for the southeastern United States. J.N. Am. Benthol. Soc. 12:279-290). Taxa were assigned to functional feeding groups in accordance with Merritt and Cumming, 1984 (An introduction to the aquatic insects). Section IV contains the ash-free biomass data for each functional feeding group present in each sample. 


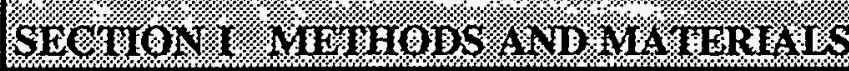

The sampling methods used in this study were identical to those used in the 1984-1985 Comprehensive Cooling Water Study (CCWS) and are described in the following text.

Hester-Dendy multiplate samplers consisting of 14 square plates measuring $7.6 \mathrm{~cm} \times 7.6 \mathrm{~cm}$ and separated by $0.3 \mathrm{~cm}$ thick spacers were utilized in this study and are illustrated in Figure 1. Five replicate samplers were suspended $0.5 \mathrm{~m}$ below the water surface at each sampling location and allowed to colorize for 28 days. Where water depth was less than $0.75 \mathrm{~m}$, the samplers were positioned mid-way between the surface and the stream bottom. The samplers were removed from the stream in a $0.5 \mathrm{~mm}$ net in order to prevent the loss of any dislodged organisms, sealed in a labelled plastic bag and kept on ice until processed in the laboratory. In the laboratory, each sampler was dissassembled, the plates scraped with a soft brush, and the removed material rinsed through a U.S. Standard No. 30 sieve $(0.6 \mathrm{~mm}$ mesh). The material retained in the sieve was perserved in $70 \%$ ethanol.

The macroinvertebrates were sorted from the debris using a stereomicroscope, identified to the lowest positive taxon and enumerated. Quality control checks were performed on $10 \%$ of the samples in order to determine the sorting efficiency. After the organisms were enumerated, the macroinvertebrates were separated into functional feeding groups following Merritt and Cummins, 1984. The ash-free dry weight of each functional group was determined by drying the organisms at $105^{\circ} \mathrm{C}$, determining the dry weight to the nearest $\mathrm{mg}$, then ashing at $500^{\circ} \mathrm{C}$ and reweighing to the nearest $\mathrm{mg}$. Ash-free dry weight is the difference between the dry weight and the ash weight. 


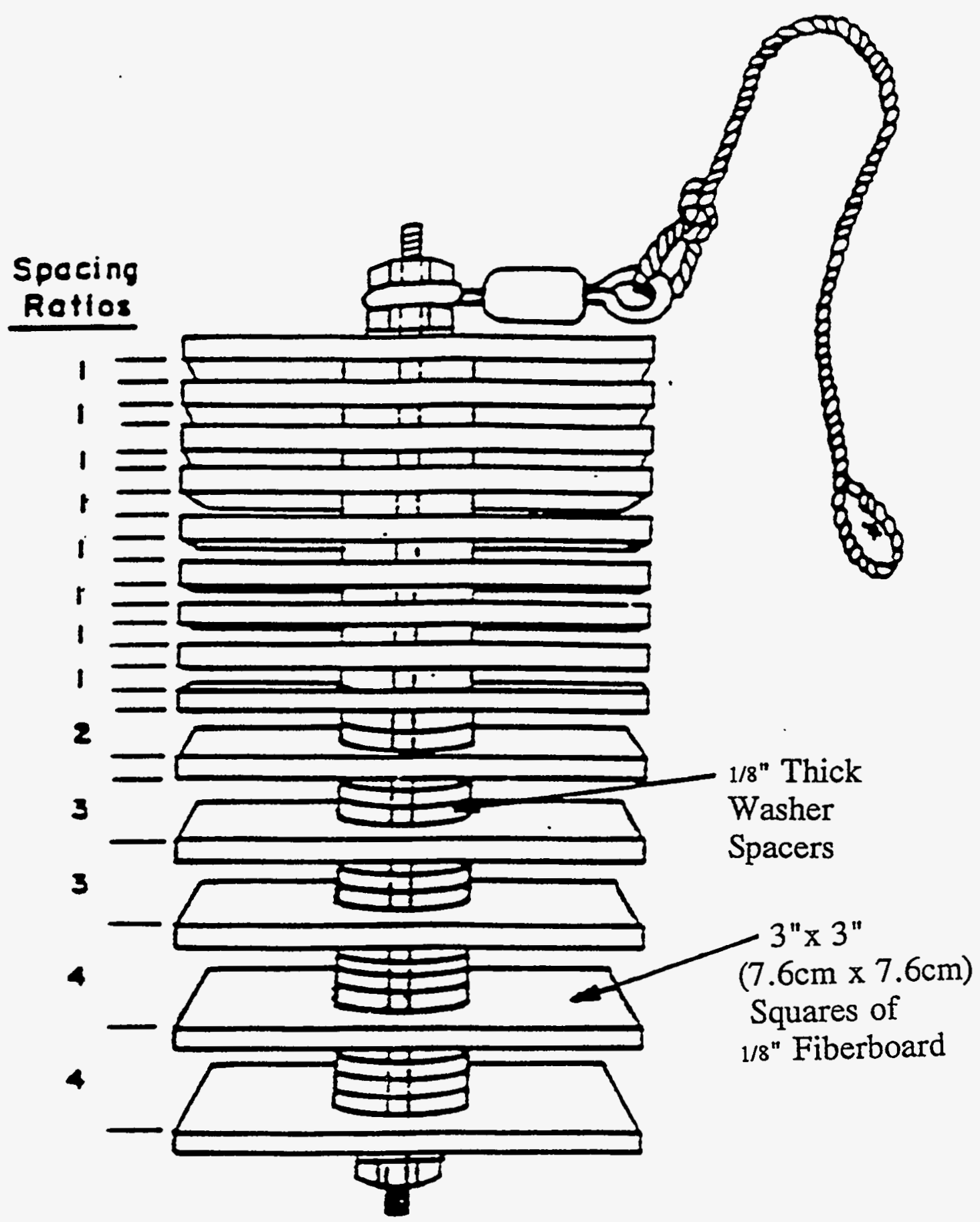

Figure 1. Diagram of Hester-Dendy Multiplate Sampler used in this study. 
For each of the sampling locations the following parameters were measured at mid-stream and mid-depth at the time of sample retrieval: conductivity (Yellow Springs Instruments Model 33), $\mathrm{pH}$ (Orion Model SA210), dissolved oxygen and temperature (Yellow Springs Instruments Model 57). A separate water sample was collected and returned to the laboratory for determination of total water hardness (Table 1).

Stream width and depth measurements were taken at each sampling location in order to construct stream cross-sectional profiles. Stream depth was measured at 10 equidistant points for streams greater than $5 \mathrm{~m}$ wide and at $50 \mathrm{~cm}$ intervals for streams less than $5 \mathrm{~m}$ wide, beginning at the stream mid-point and working toward each bank. Water velocity was measured at mid-channel using a Swoffer Model 2100 flow meter. 
Physicochemical measurements taken in conjunction with the Hester-Denty Macroinvertebrate study at the Savannah River Site, July - August, 1993. Measurements made on sampler retrieval date.

\begin{tabular}{|c|c|c|c|c|c|c|c|c|c|c|c|c|c|c|c|c|c|}
\hline Station \# & 1 & 2 & 3 & 4 & 5 & 6 & 7 & 8 & 9 & 10 & 11 & 12 & 13 & 14 & 15 & 18 & 17 \\
\hline & & & & & & & & & & & & & & & & & \\
\hline Placement Date & $7 / 22 / 93$ & $7 / 22 / 93$ & $7 / 22 / 93$ & $7 / 22 / 93$ & $7 / 22 / 93$ & $7 / 22 / 93$ & $7 / 22 / 93$ & $7 / 22 / 93$ & $7 / 23 / 93$ & $7 / 24 / 93$ & $7 / 24 / 93$ & $7 / 22 / 93$ & $7 / 24 / 93$ & $7 / 23 / 93$ & $7 / 23 / 93$ & $7 / 22 / 93$ & $7 / 22 / 93$ \\
\hline Retrieval Date & $8 / 19 / 93$ & $8 / 19 / 93$ & $8 / 19 / 93$ & $8 / 19 / 93$ & $8 / 19 / 93$ & $8 / 19 / 93$ & $8 / 19 / 93$ & $8 / 19 / 93$ & $8 / 20 / 93$ & $8 / 19 / 93$ & $8 / 19 / 93$ & $8 / 20 / 93$ & $8 / 20 / 93$ & $8 / 20 / 83$ & $8 / 20 / 93$ & $8 / 20 / 93$ & $8 / 20 / 93$ \\
\hline Time & 8:65 AM & 8:05 AM & 8:20 AM & $10: 20 \mathrm{AM}$ & 11:20 AM & 11:56 AM & 12:30 PM & 12:50 PM & $2: 20 \mathrm{PM}$ & 7:05 PM & 6:50 PM & $8: 16 \mathrm{AM}$ & 1:50 PM & 10:20 लM & 1:30 PM & $8: 30 \mathrm{AM}$ & 8:56 AM \\
\hline Hardness $(\mathrm{mg} / \mathrm{l})$ & 8.0 & 8.0 & .10 & 10 & 30 & 20 & 40 & 32 & 30 & 17 & 20 & 13 & 21 & 20 & 86 & 14 & 38 \\
\hline $\mathrm{pH}(\mathrm{SU})$ & 4.97 & 4.89 & 5.19 & 5.47 & 6.13 & 6.33 & 0.21 & 6.34 & 8.18 & 8.89 & 6.71 & 5.46 & 6.59 & 6.02 & 6.13 & 5.79 & 5.69 \\
\hline Conductivity (umhos $/ \mathrm{cm}$ ) & 15.0 & 20.0 & 20.0 & 20.0 & 35.0 & 25.0 & 40.0 & 55.0 & 46.0 & 65.0 & 80.0 & 105.0 & 20.0 & 75.0 & 100.0 & 80.0 & 35.0 \\
\hline DO (mg/l) & 7.6 & 7.4 & 요. & 7.6 & 5.7 & 7.4 & 7.2 & 7.8 & 7.6 & 5.2 & 7.0 & 4.4 & 8.0 & 7.2 & 0.8 & 7.5 & 4.0 \\
\hline Tomporaturo (C) & 22.6 & 22.7 & 24.1 & 23.8 & 27.4 & 25.7 & 28.4 & 28.4 & 26.7 & 25.7 & 25.4 & 23.4 & 25.3 & 25.6 & 27.2 & 24.0 & 25.3 \\
\hline Flow $(\mathrm{m} / \mathrm{s})$ & 0.43 & 0.25 & 0.46 & 0.37 & 0.21 & 0.32 & 0.04 & 0.01 & 0.02 & 0.50 & 0.40 & 0.00 & 0.47 & 0.37 & 0.30 & 0.35 & 0.00 \\
\hline Stream Width $(\mathrm{m})$ & 7.50 & 4.42 & 2.80 & 12.19 & 8.99 & 8.50 & 1.95 & 6.18 & 2.59 & 2.07 & 2.87 & 0.91 & 16.64 & 3.17 & 7.25 & 2.83 & 2.50 \\
\hline \multicolumn{18}{|l|}{ Imotors from loft bank) Dopth } \\
\hline Dopth 1 & (0) 0 & 1010 & (0) 0 & (0) 0 & 1010 & (0) 0 & (0) 0 & 1010 & (0) 0 & (0) 0 & (0) 0 & 10) 0 & (0) 0 & 1010 & 1010 & (0) 0 & 10) 0 \\
\hline Dopth 2 & $(0.7) 0.3$ & (0.6) 0.12 & $(0.5) 0.12$ & $(1.111 .01$ & (0.8) 0.27 & (0.8) 0.58 & 10.310 .52 & 10.610 .46 & 10.410 .15 & $(0.3) 0.49$ & 10.510 .30 & (0.3) 0.12 & $(1.4) 0.82$ & $0.4) 0.09$ & $(0.710 .67$ & $(0.5) 0.12$ & $(0.4) 0.34$ \\
\hline Dopth 3 & (1.4) 0.55 & (1.1) 0.49 & $(0.9) 0.30$ & $(2.2) 1.74$ & $(1.6) 0.46$ & (1.6) 0.56 & $(0.5) 0.58$ & $(1.0) 0.73$ & 10.910 .18 & $(0.5) 0.46$ & $(1.0) 0.30$ & 10.510 .27 & $(2.8)_{0.76}$ & $(0.8) 0.40$ & (1.3) 0.73 & $(1.0) 0.09$ & (0.8) 0.58 \\
\hline Dopth 4 & $(2.0) 0.67$ & (1.7) 0.55 & 11.410 .30 & (3.3) 1.40 & $(2.5) 0.52$ & (2.3) 0.52 & $0.8) 0.52$ & 11.710 .91 & 11.310 .15 & $(1.0) 0.43$ & $(1.5) 0.24$ & (0.8) 0.08 & $(4.3) 0.70$ & $11.2) 0.37$ & $(2.0) 0.91$ & 11.410 .09 & (1.3) 0.62 \\
\hline Dopth 5 & (2.7) 0.70 & (2.2) 0.58 & $(1.910 .37$ & $(4.4) 0.91$ & (3.3) 0.64 & (3.1) 0.46 & $(1.0) 0.52$ & (2.3) 1.01 & $(1.7) 0.12$ & (1.3) 0.34 & (1.9) 0.18 & 10.810 & $(5.7) 0.76$ & (11.6) 0.49 & $(2.6) 1.16$ & $(1.8) 0.16$ & (1.7) 0.49 \\
\hline Dopth 6 & (3.4) 0.64 & (2.8) 0.43 & $(2.4) 0.40$ & $(5.6) 0.79$ & $(4.1) 0.61$ & $(3.9) \quad 0.30$ & 11.310 .49 & $(2.8) 0.82$ & (2.2) 0.06 & $(1.5) 0.15$ & $(2.4) 0.12$ & & $(7.1) 0.91$ & $(2.0) 0.46$ & $(3.3) 1.10$ & $(2.4) 0.24$ & $(2.1) 0.40$ \\
\hline Dopth 7 & $(4.1) 0.46$ & (3.3) 0.30 & $(2.8) 0$ & $18.7) 0.73$ & (4.9) 0.61 & (4.6) 0.24 & $(1.5) 0.30$ & $(3.4) 0.79$ & $(2.6) 0$ & $(2.0) 0$ & 12.910 & & $(8.5) \quad 0.79$ & $(2.4) 0.37$ & $(4.0) 1.16$ & 12.910 & (2.5) 0 \\
\hline Dopth 8 & (4.8) 0.46 & (3.9) 0.15 & & $(7.810 .76$ & $(5.7) 0.70$ & 15.410 .30 & (1..8) 0.12 & (3.9) 0.67 . & & & & & $(9.9) 0.70$ & (2.8) 0.34 & $(4.6) 1.13$ & & \\
\hline Dopth 9 & 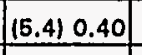 & 14.410 & & $(8.9) 0.34$ & $18.6) 0.73$ & $(6.2) 0.37$ & $(2.0) 0$ & (4.6) 0.67 & & & & & $(11.310 .87$ & $(3.2) 0$ & $(5.3) 1.10$ & & \\
\hline Dopth 10 & $(6.1) 0.40$ & & & (110) 0.24 & $(7.4) 0.67$ & $(7.0) 0.27$ & & $15.1) 0.70$ & & & & & (12.810.61 & & (5.8)1.01 & & \\
\hline Dopth 11 & (6.8) 0.40 & & & 111.110 .08 & $(8.2) 0.40$ & $(7.7) .018$ & & $(5,8) 0.18$ & & & & & $(14.210 .30$ & & $(6.6) 0.98$ & & \\
\hline Dopth 12 & 17.610 & & & 112.210 & $19.0) 0$ & 18.510 & & 16.210 & & & & & \begin{tabular}{|l|}
$(15.6) 0$ \\
\end{tabular} & & $(7.310$ & & \\
\hline
\end{tabular}


Physicochemical measurements taken in conjunction with the Hester-Denty Macroinvertebrate study at the Savannah River Site, July - August, 1993. Measurements made on sampler retrieval date.

\begin{tabular}{|c|c|c|c|c|c|c|c|c|c|c|c|c|c|c|c|c|}
\hline Station \# & 18 & 19 & 20 & 21 & 22 & 23 & 24 & 25 & 26 & 27 & 28 & 29 & 30 & 31 & 32 & 33 \\
\hline & & & & & & & & & & & & & & & & \\
\hline Placement Date & $7 / 23 / 93$ & $7 / 23 / 93$ & $7 / 22 / 93$ & $7 / 22 / 93$ & $7 / 22 / 93$ & 7/23/93 & $7 / 23 / 93$ & $7 / 23 / 93$ & $7 / 23 / 93$ & $7 / 22 / 93$ & $7 / 23 / 93$ & $7 / 24 / 93$ & $7 / 24 / 93$ & $7 / 24 / 93$ & $7 / 24 / 93$ & $7 / 23 / 93$ \\
\hline Retrieval Date & $8 / 19 / 93$ & $8 / 20 / 93$ & $8 / 20 / 93$ & $8 / 19 / 93$ & $8 / 19 / 93$ & $8 / 19 / 93$ & $8 / 20 / 93$ & $8 / 20 / 93$ & $8 / 20 / 93$ & $8 / 19 / 93$ & $8 / 19 / 93$ & $8 / 19 / 93$ & $8 / 19 / 93$ & $8 / 19 / 93$ & $8 / 20 / 93$ & $8 / 20 / 93$ \\
\hline Time & 6:00 PM & $10: 50 \mathrm{AM}$ & 11:35 AM & 4:10 PM & 3:50 PM & 5:35 PM & 12:05 PM & 12:25 PM & 1:10 PM & 3:07 PM & 6:10 PM & 4:45 PM & 1:30 PM & $2: 20 \mathrm{PM}$ & 9:00 AM & 7:35 AM \\
\hline Hardness (mg/I) & 8.0 & 16 & 25 & 16 & 24 & 20 & 31 & 31 & 44 & 12 & 27 & 13 & 18 & 23 & 11 & 26 \\
\hline $\mathrm{pH}(\mathrm{SU})$ & 6.4 & 6.2 & 7.0 & 6.3 & 6.3 & 6.4 & 7.2 & 6.2 & 5.3 & 6.6 & 6.0 & 5.3 & 6.5 & 6.4 & 5.8 & 5.4 \\
\hline Conductivity (umhos $/ \mathrm{cm}$ ) & 20.0 & 75.0 & 70.0 & 80.0 & 45.0 & 70.0 & 75.0 & 90.0 & 25.0 & 60.0 & 65.0 & 30.0 & 50.0 & 65.0 & 25.0 & 60.0 \\
\hline DO $(\mathrm{mg} / \mathrm{ll}$ & 7.5 & 7.4 & 7.9 & 8.3 & 7.2 & 8.2 & 8.7 & 0.2 & 2.1 & 7.8 & 6.5 & 3.7 & 5.8 & 7.4 & 7.7 & 7.5 \\
\hline Temperature (C) & 24.60 & 26.30 & 27.20 & 29.00 & 27.90 & 28.90 & 27.50 & 29.60 & 24.00 & 32.70 & 30.20 & 29.00 & 31.30 & 28.60 & 23.20 & 22.60 \\
\hline Flow $(\mathrm{m} / \mathrm{s})$ & 0.49 & 0.55 & 0.12 & 0.18 & 0.17 & 0.22 & 0.35 & 0.00 & 0.00 & 0.00 & 0.38 & 0.00 & 0.44 & 0.18 & 0.42 & 0.25 \\
\hline Stream width $(m)$ & 14.63 & 3.66 & 13.11 & 12.13 & 3.38 & 10.61 & 0.42 & NA & 1.16 & 33.53 & 11.28 & 3.60 & 7.50 & 13.35 & 13.05 & 9.75 \\
\hline \multicolumn{17}{|l|}{ (moters from Left bank) Dap } \\
\hline Depth 1 & (0) 0 & (0) 0 & $(0) 0$ & 1010 & (0) 0 & (0) 0 & (0) 0 & 0.21 & (0) 0 & (0) 0 & $10) 0$ & (0) 0 & (0) 0 & (0) 0 & (0) 0 & (0) 0 \\
\hline Depth 2 & (1..3) 0.82 & (0.6) 0.21 & $(1.2) 0.37$ & $(1.1) 0.30$ & $(0.8) 0.8$ & $(1.0) 0.62$ & 10.910 .15 & 0.37 & $(0.9) 0.01$ & (3.1) 1.88 & $(1.0) 0.73$ & $(0.5) 0.15$ & $(0.7) 0.24$ & (1.2) 0.58 & $(1.2) 0.49$ & $(0.9) 0.08$ \\
\hline Depth 3 & $(2.7) 1.10$ & $(1.2) 0.15$ & $(2.4) 0.58$ & $(2.2) 0.56$ & $(1.1) 0.09$ & $(1.9) 0.40$ & (1.9) 0.18 & & (1.9) 0.68 & $(8.1) 2.44$ & $(2.1) 1.01$ & $(0.9) 0.21$ & (1.4) 0.81 & (2.4) 1.01 & (2.4) 1.10 & $(1.8) 0.55$ \\
\hline Depth 4 & $(4.0) 1.31$ & $(1.9) 0.30$ & $(3.6) 0.49$ & $(3.3) 0.67$ & $11.7 \quad 0.15$ & $(2.9) 0.34$ & $(2.8) 0.18$ & & $(2.9) 0.34$ & $(9.1) 2.29$ & (3.1) 1.25 & $(1.4) 0.55$ & (2.1) 0.73 & (3.8) 3.07 & (3.6) 1.25 & $(2.7) 0.70$ \\
\hline Depth 5 & (5.3) 1.37 & $(2.5) 0.37$ & $(4.8) 0.62$ & $(4.4) 0.70$ & (2.3) 0.12 & $(3.9) 0.48$ & $(3.8) 0.21$ & & (3.8) 0 & $(12.212 .29$ & (4.1) 1.16 & (1.8) 0.83 & (2.7) 0.87 & (4.8) 1.07 & (14.8) 1.28 & (3.5) 0.94 \\
\hline Depth 6 & $(6.6) 1.34$ & $(3.1) 0.30$ & (5.9) 0.43 & $(5.5) 0.70$ & (2.8) 0.15 & $(4.8) 0.52$ & $(4.7) 0.21$ & & & $(15.2) 2.23$ & $(5.1) 1.13$ & $(2.3) 0.64$ & $(3.4) 0.58$ & $(8.1) 1.10$ & $(5.9) \quad 1.22$ & $(4.4) 0.98$ \\
\hline Depth 7 & $(8.0) 1.22$ & $(3.7) 0$ & $(7.1) 0.37$ & $(8.0) 0.73$ & $(3.4) 0$ & $(5.8) 0.81$ & $\begin{array}{lll} & (5.7) & 0.27 \\
\end{array}$ & & & $(18.3) 2.23$ & (8.2) 0.98 & $(2.7) 0.52$ & $(4.1) 0.62$ & (7.3) 1.16 & (7.1) 1.19 & $(6.3) 1.19$ \\
\hline Depth 8 & $(9.3) 1.07$ & & $(8.3) 0.43$ & $(7.7) 0.79$ & & $(8.7) 0.81$ & $(6.0) 0.34$ & & & 121.312 .16 & $(7.2) 0.79$ & $(3.1) 0.15$ & $(4.8) 0.52$ & $(8.5) 0.98$ & $(8.3) 1.22$ & $(8.2) 1.1$ \\
\hline Depth 9 & $(10,0) 0,91$ & & $(9.5) 0.52$ & $(8.8) 0.73$ & & (7.7) 0.70 & $(7.6) 0.37$ & & & $(24.012 .74$ & $(8.2) 0.70$ & $(3.8) 0$ & $(5.5) 0.48$ & $(9.7) 0.88$ & $(9.6) 1.07$ & $(7.1) 1.37$ \\
\hline Depth 10 & $(12.0) 0.91$ & & $(10.7) 0.6$ & $(9.9) 0.46$ & & $(8.7) 0.73$ & $3(8.5) 0.43$ & & & $(27.4) 2.29$ & $(9.3) 0.64$ & & 18.110 .43 & 110.910 .81 & 110.710 .01 & (7.9) 1.37 \\
\hline Depth 11 & $(13.3) 0.84$ & & $(11.0) 0.5$ & (11 1.010.27 & & $(9.6) 0.81$ & $(9.5) 0.87$ & & & 130.511 .68 & $(10.3) 0.84$ & & $(8.8) 0.30$ & 112.110 .15 & 111.910 .49 & $(8.8) 9.65$ \\
\hline Depth 12 & $(14.8) 0$ & & $|(13.1) 0|$ & $(12.1) 0$ & & {$[(10.8) 0$} & $(10.4) 0$ & & & (33.5) 0 & $111.3) 0$ & & $(7.6) 0$ & $(13.3) 0$ & $(13.1) 0$ & $(9.7) 0$ \\
\hline
\end{tabular}


Station 1. Upper Three Runs Cr.@ Banks Mill Rd.

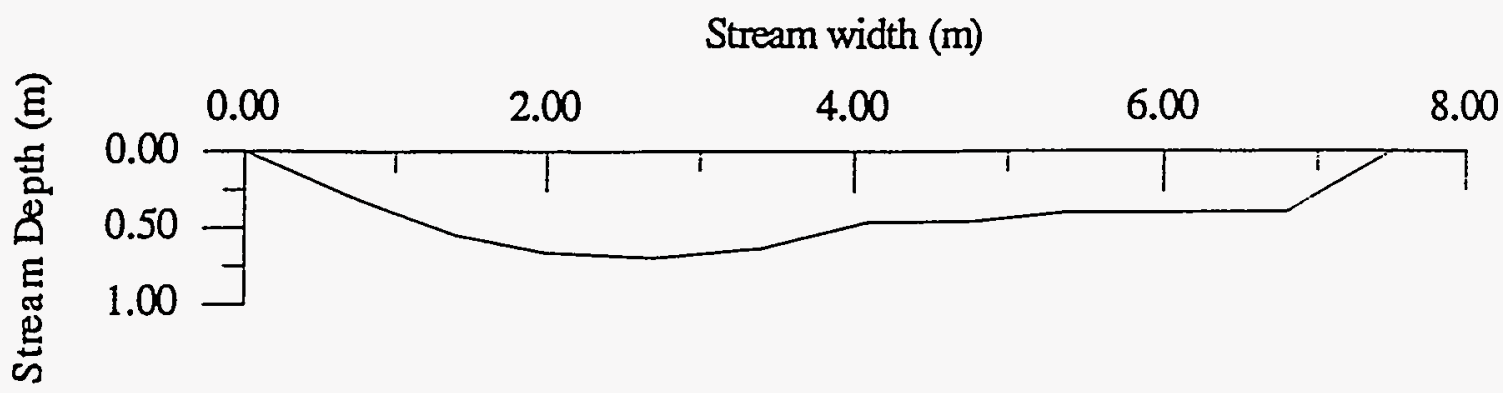

Station 2. Cedar Creek @ Banks Mill Rd.

Stream Width (m)

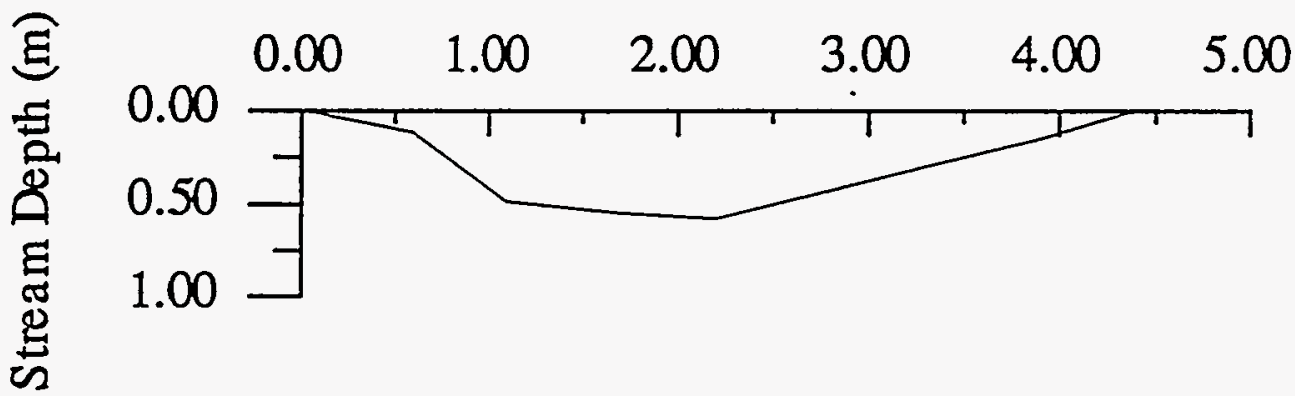

Station 3. Boggy Gut at Rd. 781.4.

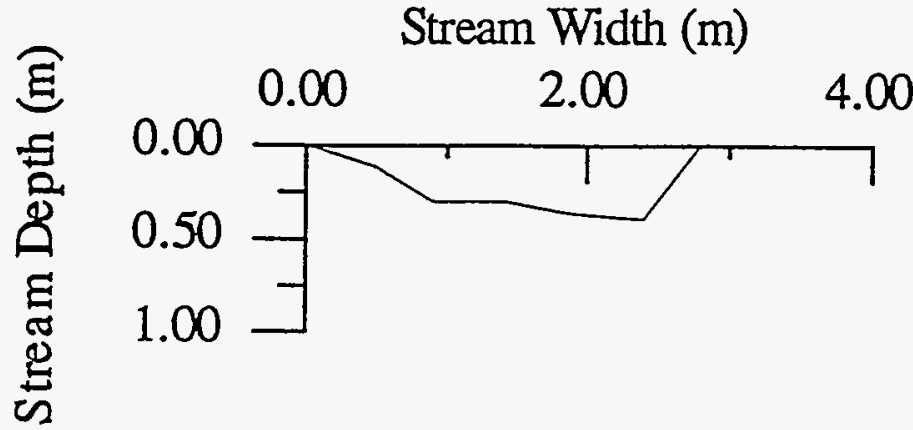


Station 4. U pper Three Runs Cr. @ RD. 8-1.

Stream Width (m)

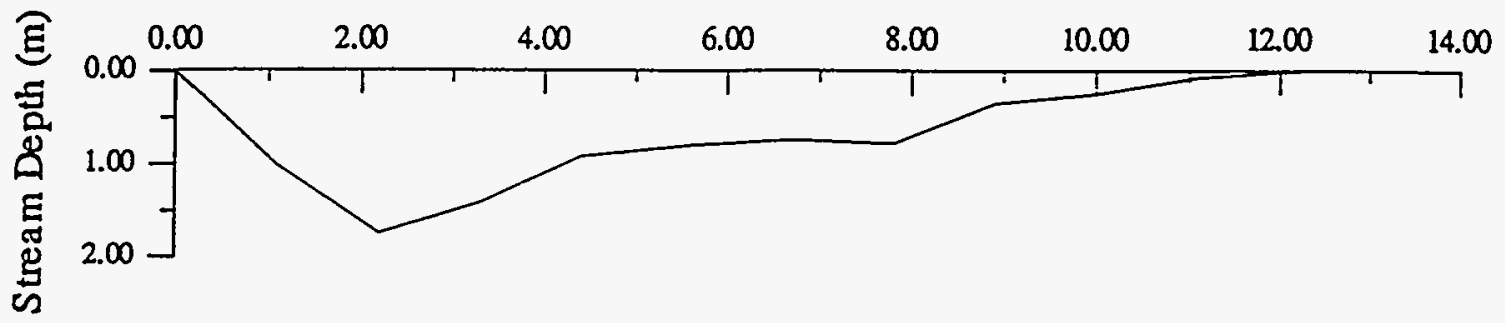

Station 5. Tinker Cr. @ Kennedy's Pond Rd.

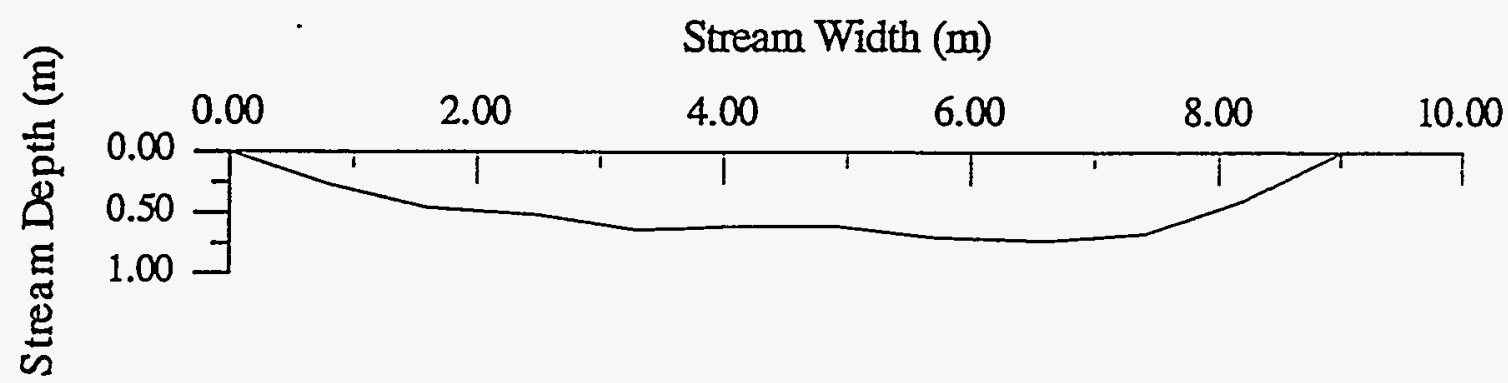

Station 6. Tinker Cr. @ Rd. 2-1.

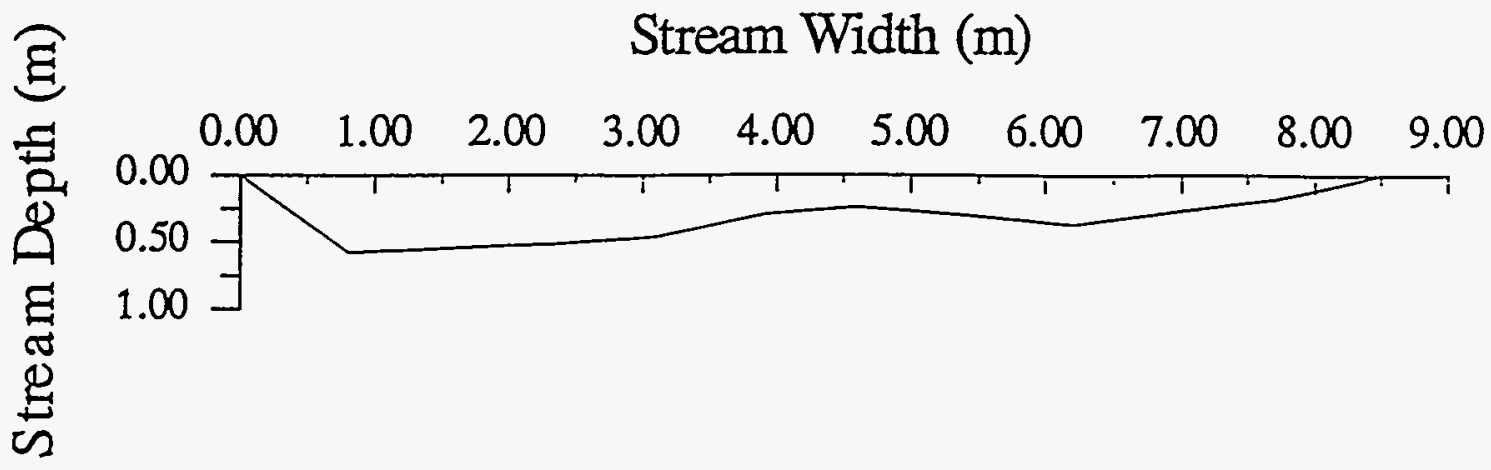


Station 7. Reedy Branch nr. ATTA Site

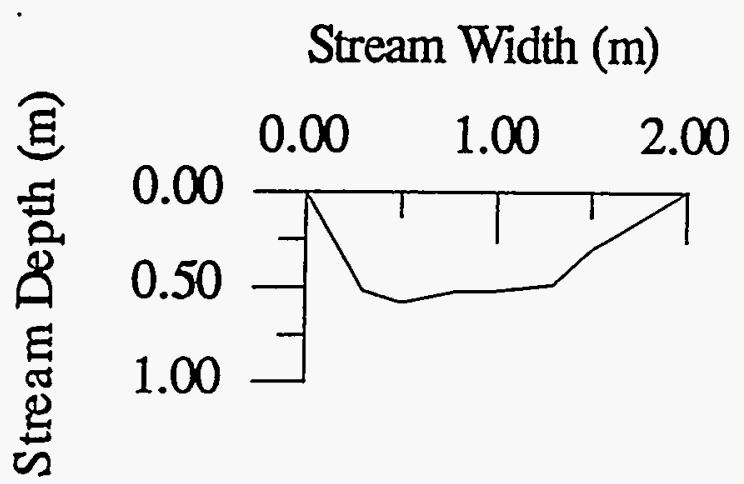

Station 8. Mill Creek @ Rd. E-2.

Stream width (m)

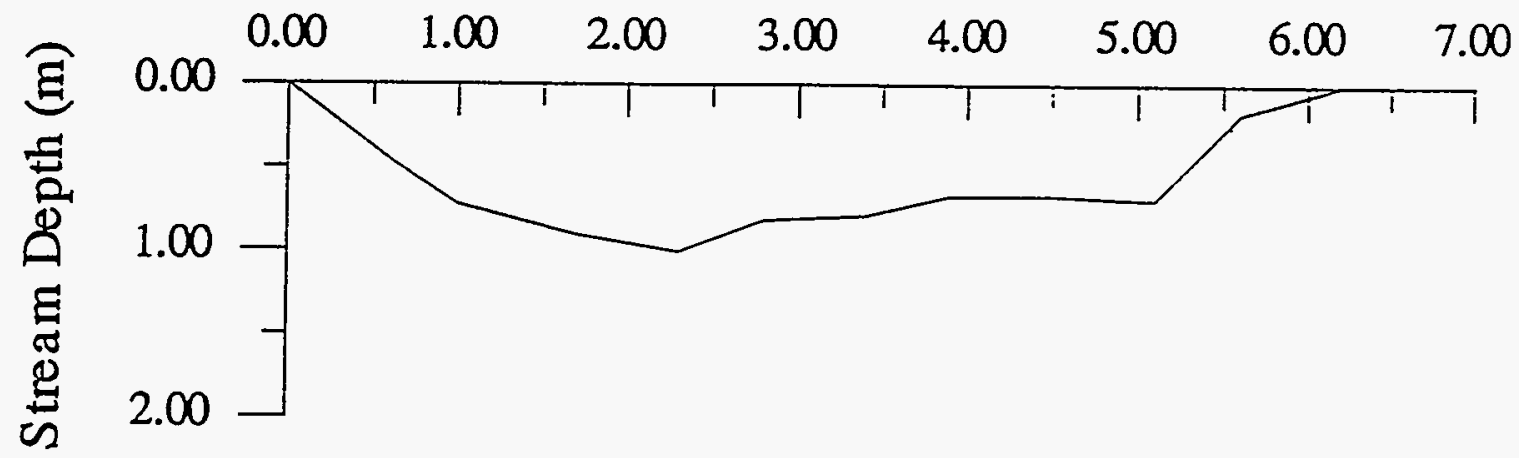

Station 9. McQueen's Branch @ Rd. F.

Stream Width (m)

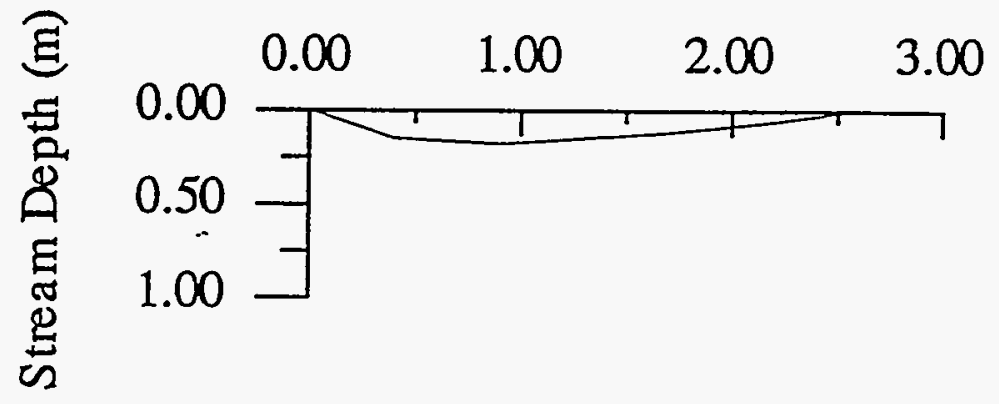


Station 10. Tims Branch @ Rd. 2.

Stream Width (m)

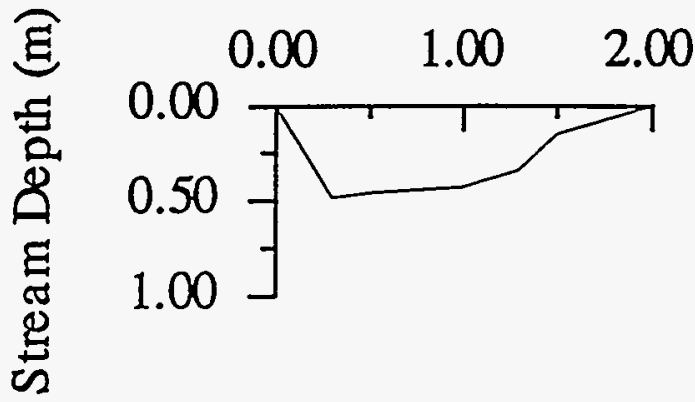

Station 11. Tims Branch @ Rd. C.

Stream Width (m)

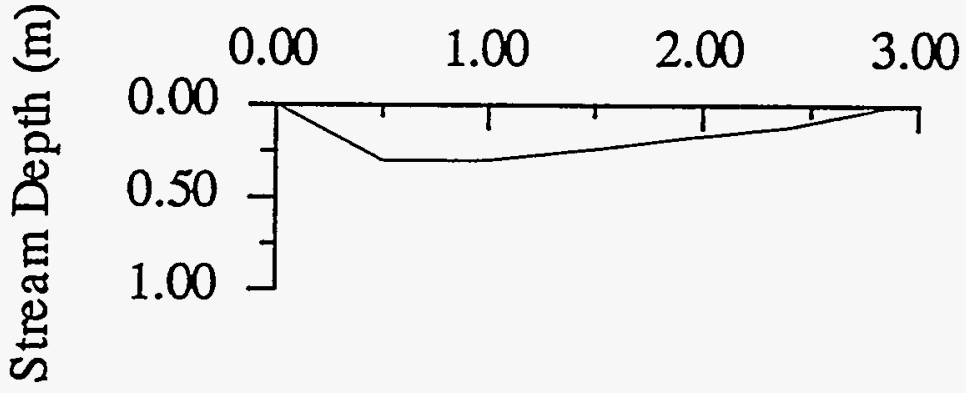

Station 12. Crouch Branch @ Rd. 4.

Stream Width (m)

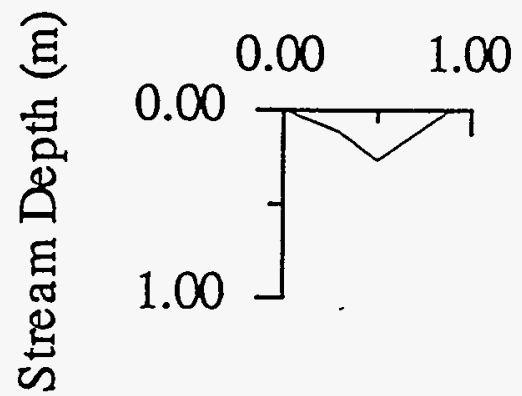


Station 13. Upper Three Runs Cr. @ Rd. C.

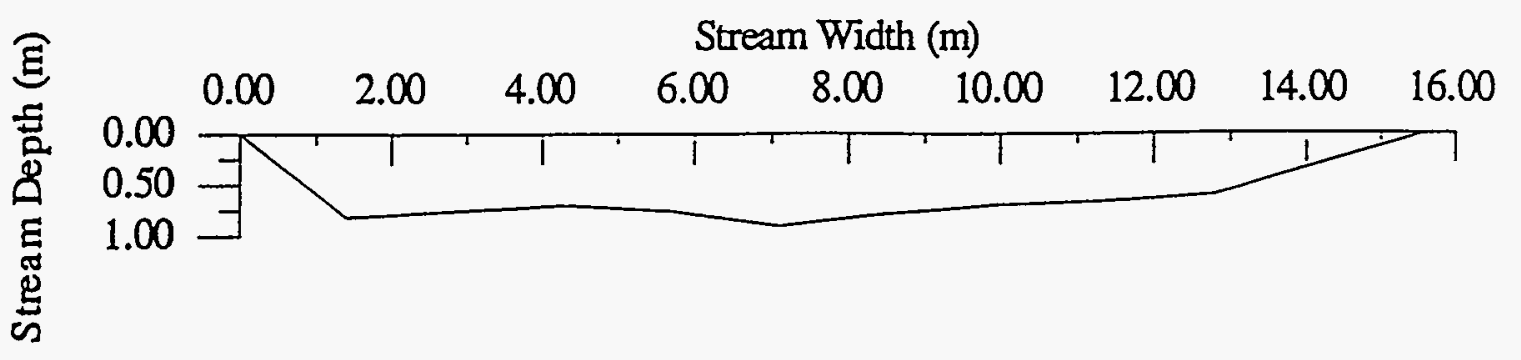

Station 14. Four Mile Creek @ Rd. C-4.

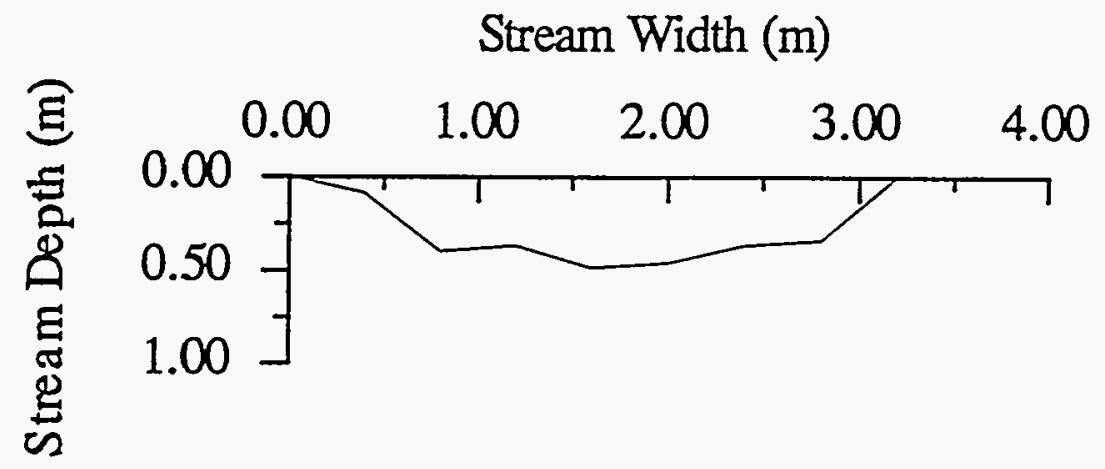

Station 15. Four Mile Creek @ Rd. C.

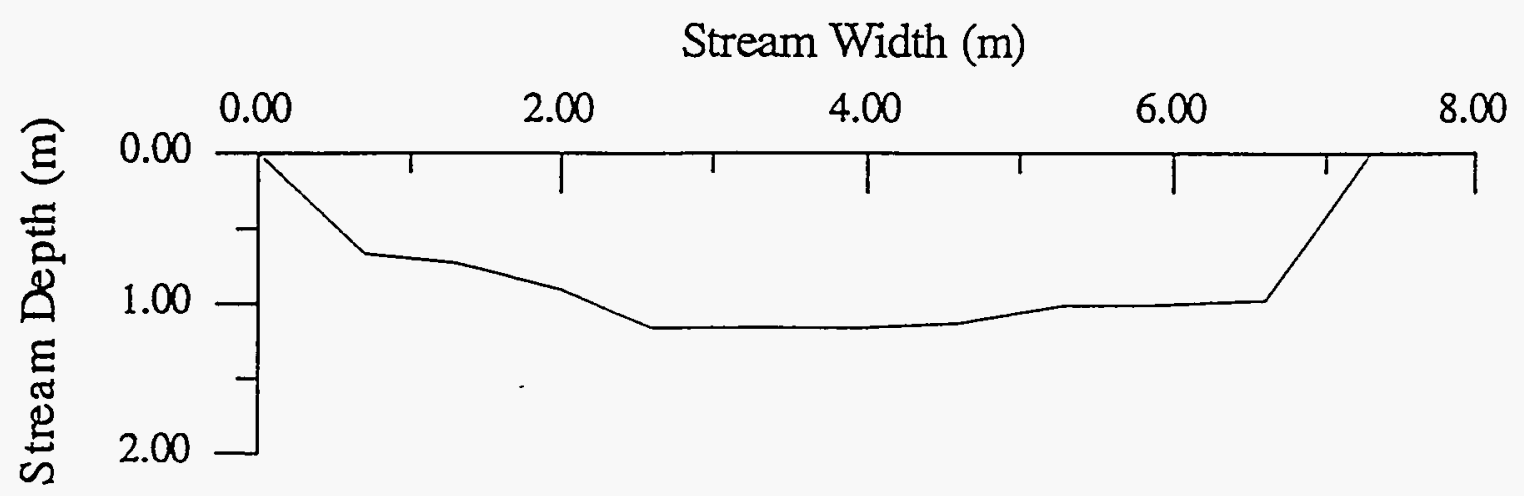


Station 16. Four Mile Creek @ Rd. 4.

Stream Width (m)

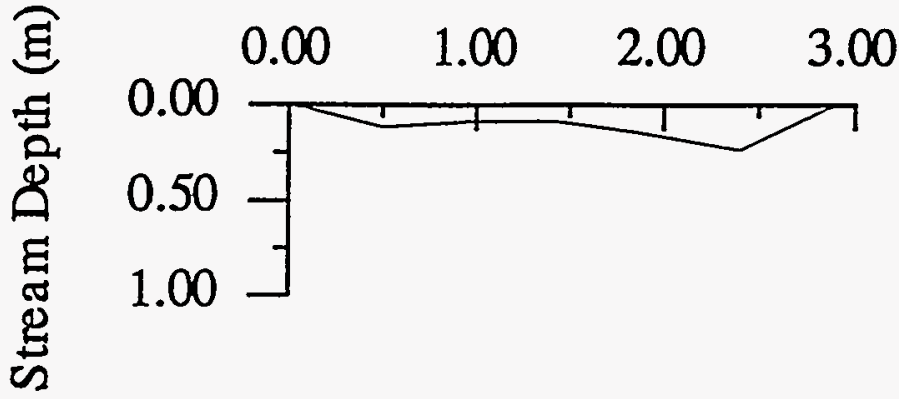

Station 17. Four Mile Creek @ Rd. E-1.

Stream Width (m)

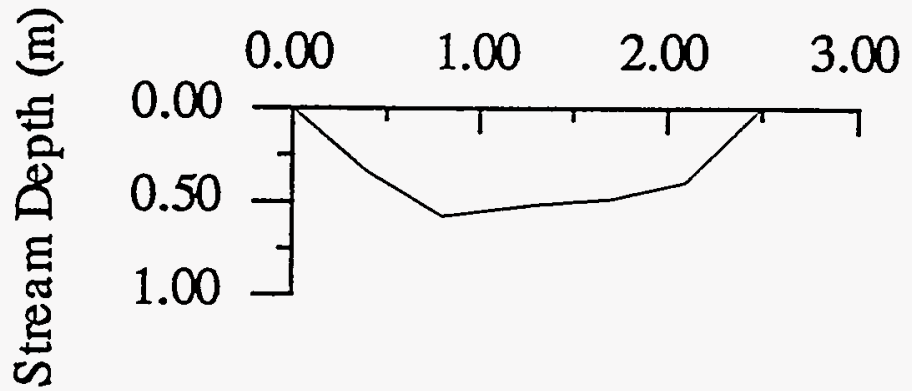

Station 18. Upper Three Runs Cr. @ Rd. A.

Stream width $(\mathrm{m})$

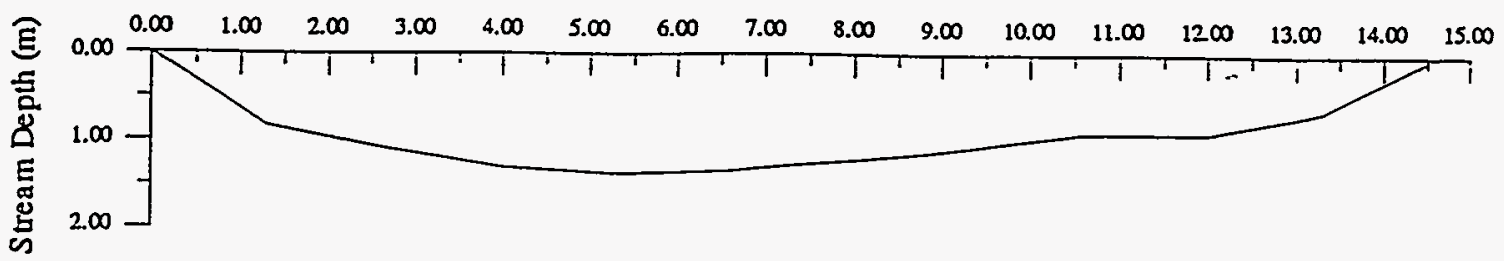




\section{Station 19. Four Mile Creek @ Rd. A-7.}

Stream Width $(\mathrm{m})$

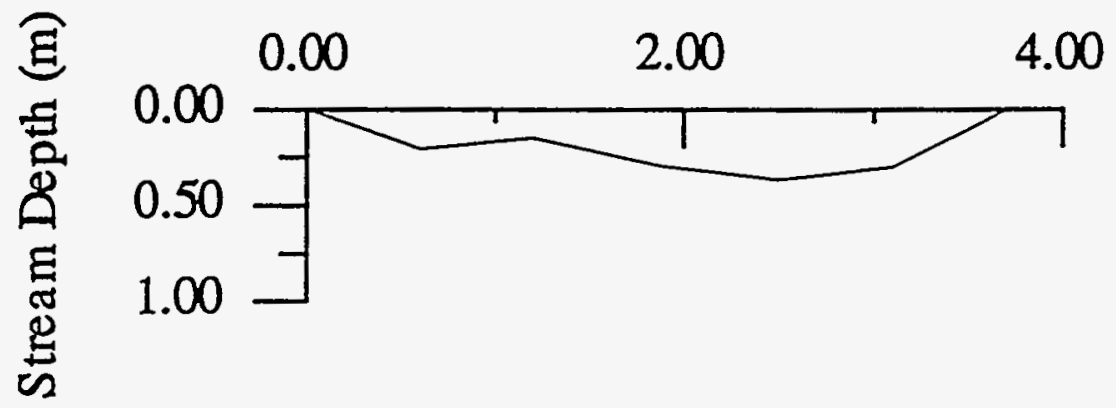

Station 20. Four Mile Creek @ Rd. A 13.2.

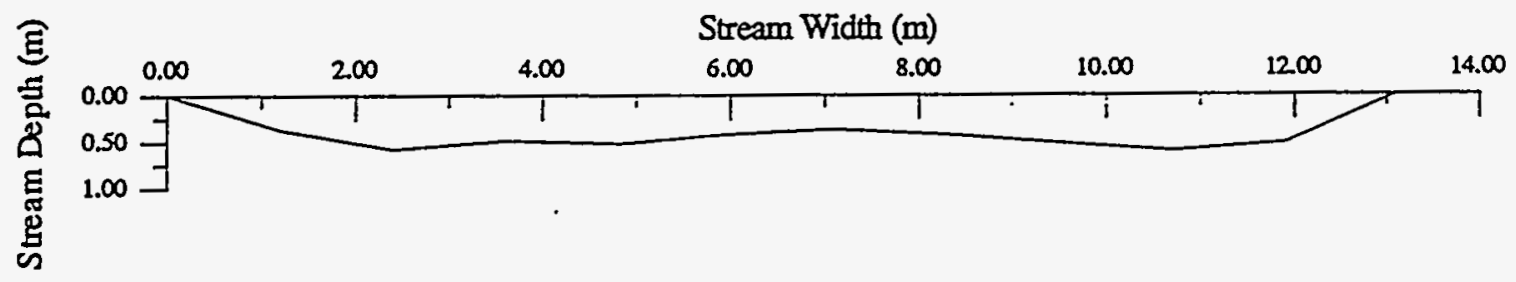

Station 21. Indian Grave Branch @ Rd. B.

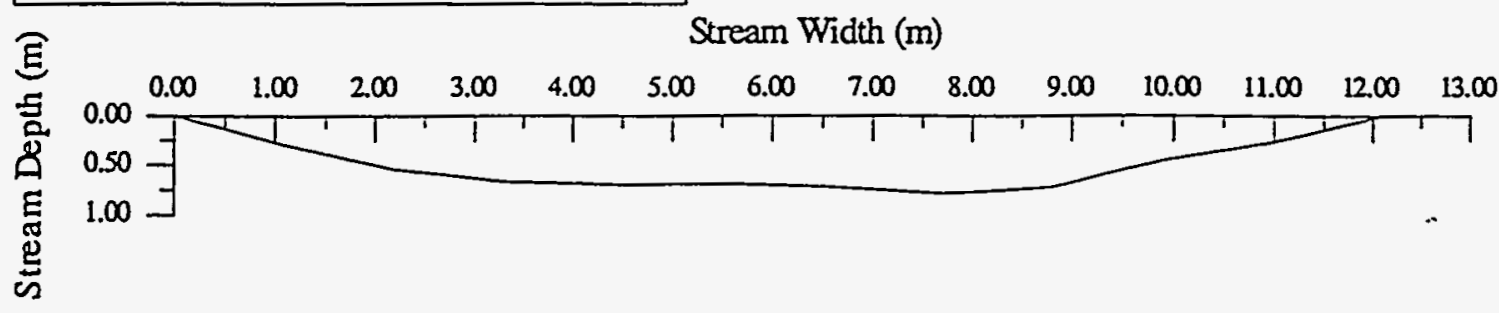


Station 22. Pen Branch @ Rd. B.

Stream Width (m)

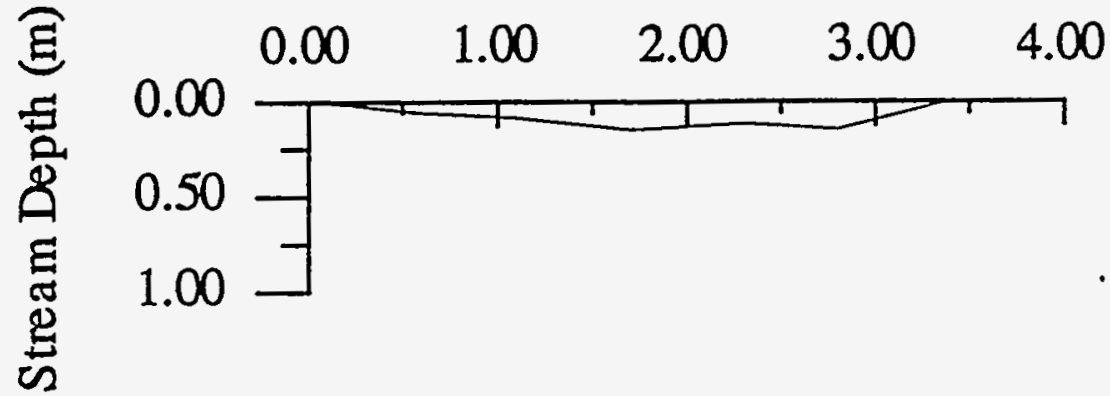

Station 23. Pen Branch @ Rd. A.

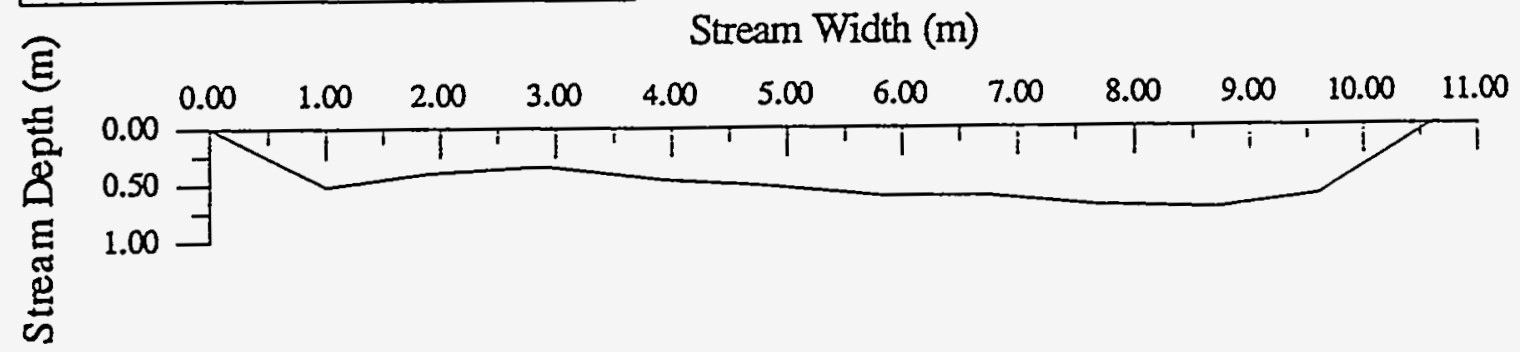

Station 24 . Pen Branch @ Rd. A 13.2.

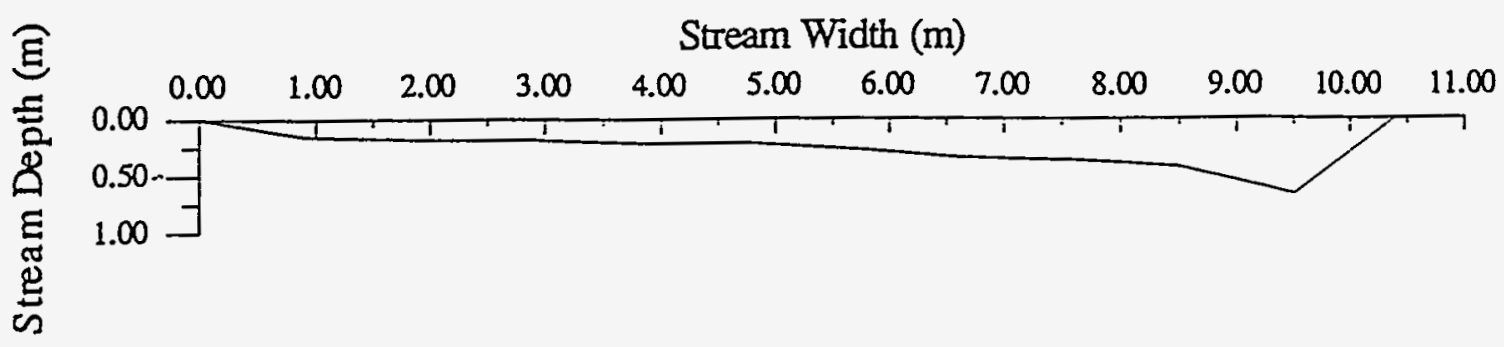


Station 26. Pen Branch @ Rd. C.

Stream Width (m)

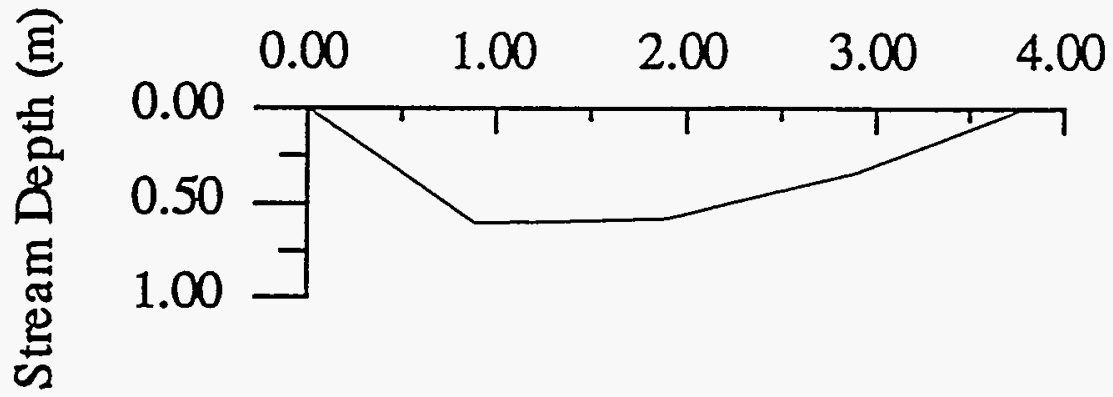

Station 27. Steel Creek @ Rd. B.

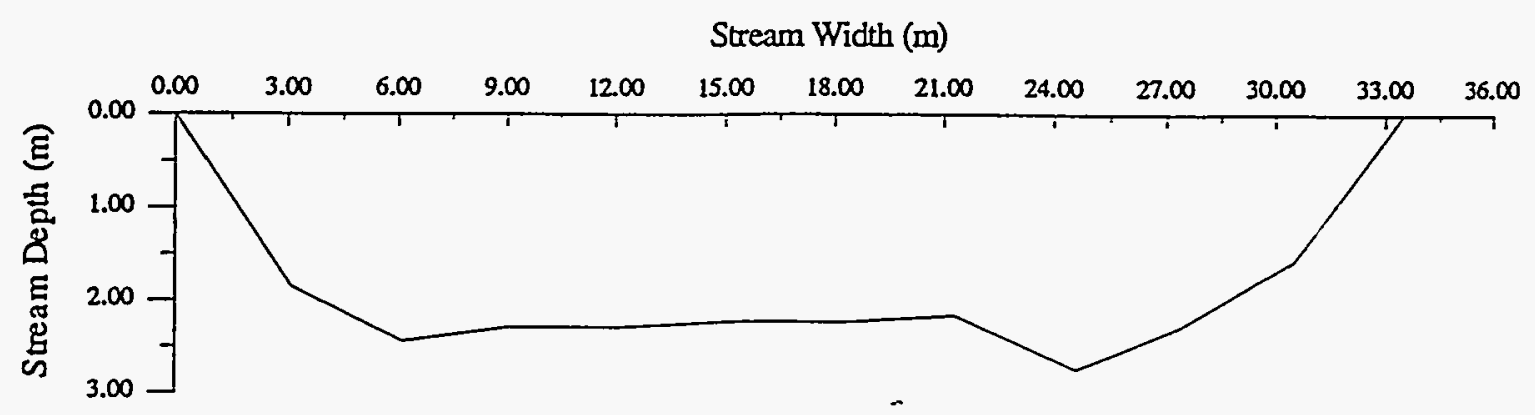


Station 28. Steel Creek @ Rd. A.

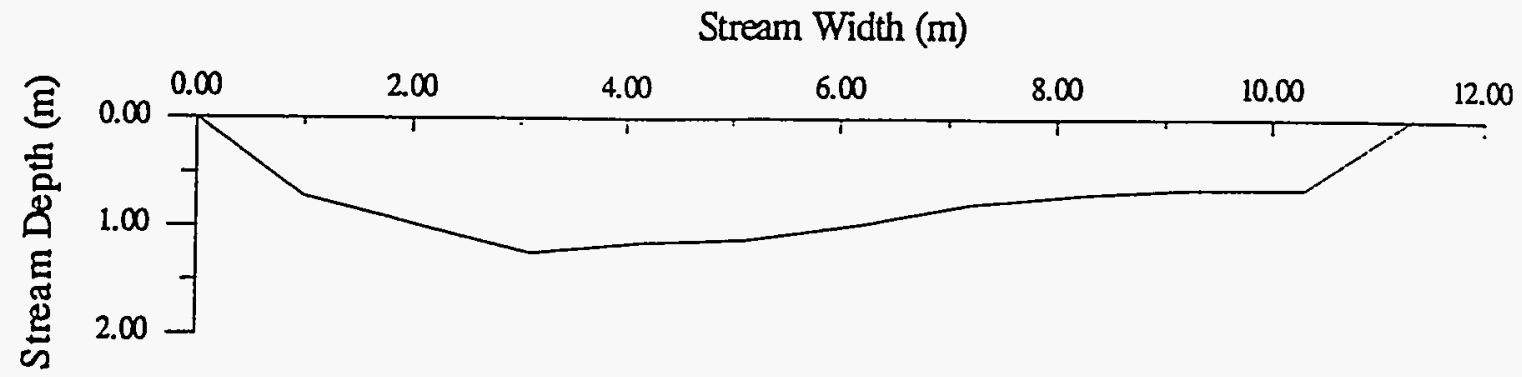

Station 29. Unnamed Tributary of Steel Creek @ Rd.125.

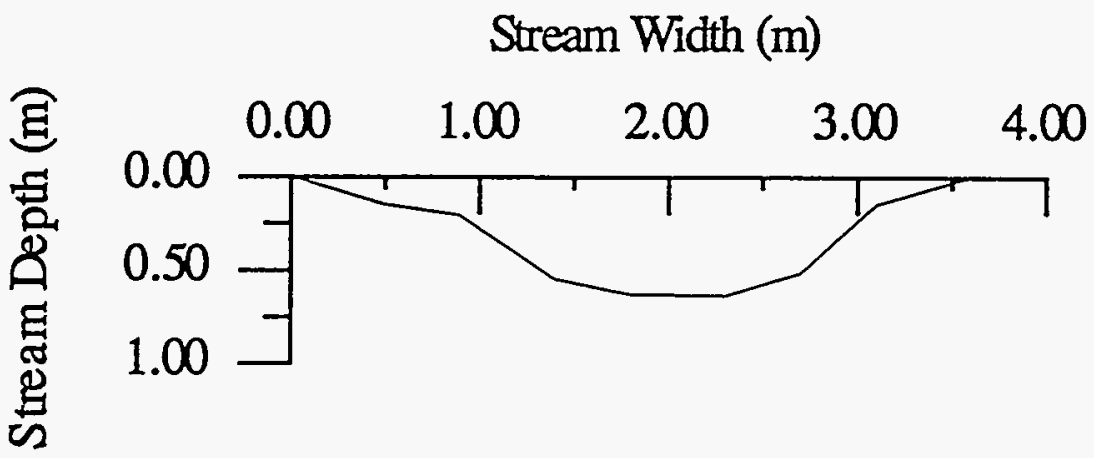

Station 30. Lower Three Runs Cr. @ Donora.

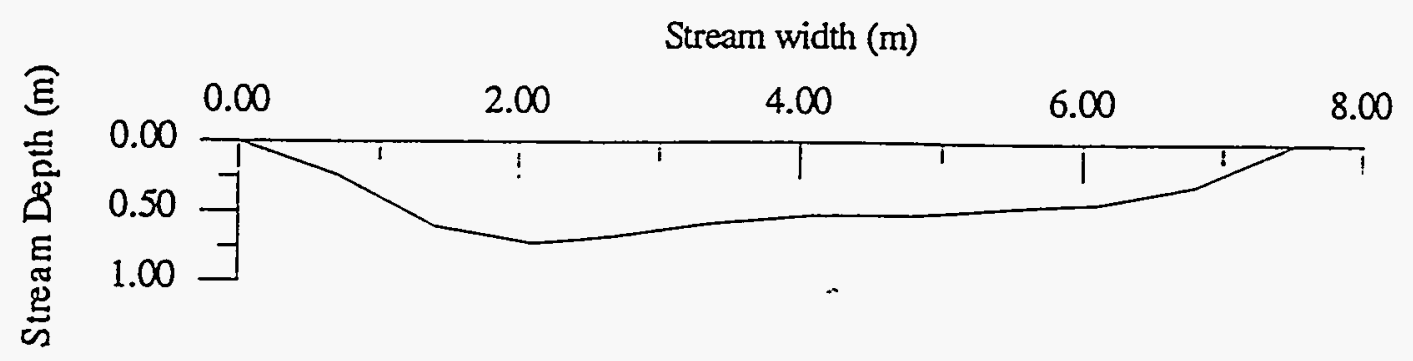


Station 31. Lower Three Runs Cr. @ Patterson Mill Rd.

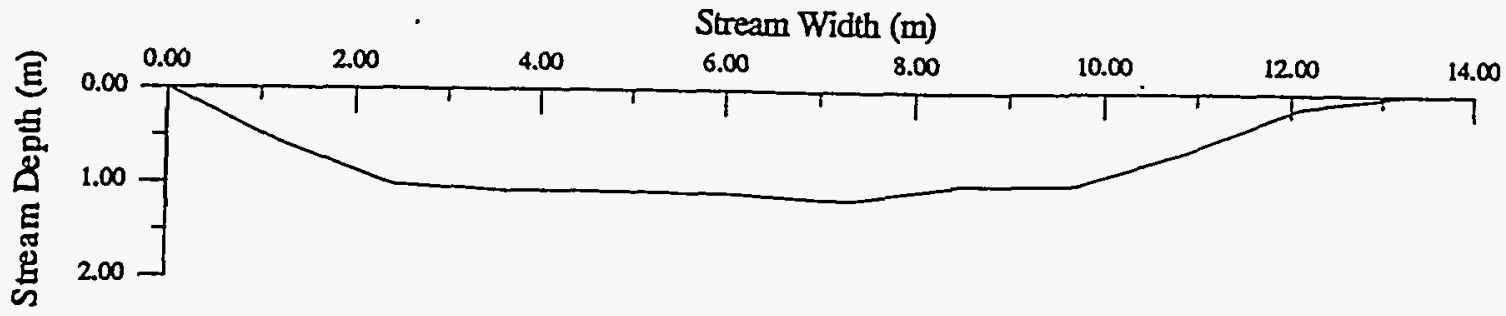

Station 32. Upper Three Runs Cr. @ RR Bridge.

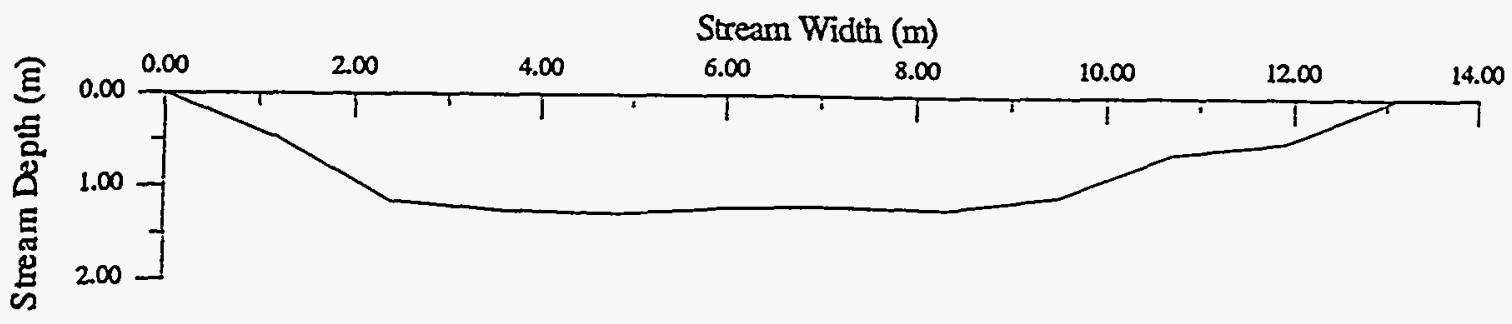

Station 33. Upper Three Runs Cr. @ Rd. F.

Stream Width (m)

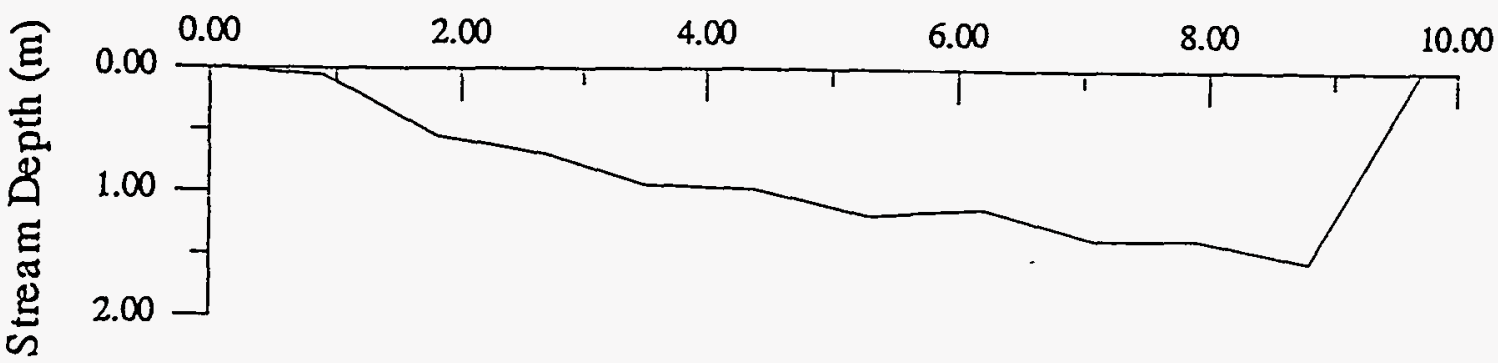




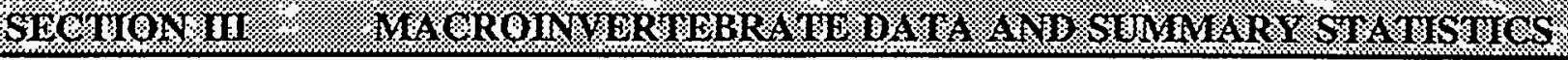


Table 2. Abbreviations and explanation of terms used in the macroinvertebrate data and summary statistics p.20-21

I. Codes of Major Taxa

\begin{tabular}{|c|c|c|}
\hline ANO & - & Annelida, Oligochaeta \\
\hline $\mathrm{ANH}$ & - & Annelidae, Hirudinea \\
\hline $\mathrm{AHC}$ & - & Acari, Hydracarina \\
\hline AMG & - & Amphipoda, Gammaridae \\
\hline AMT & - & Amphipoda, Talitridae \\
\hline DCA & - & Decapoda, Cambaridae \\
\hline EP & - & Hexapoda, Ephemeroptera \\
\hline OD & - & Hexapoda, Odonata \\
\hline PL & - & Hexapoda, Plecoptera \\
\hline 10) & - & Hexapoda, Coleoptera \\
\hline $\mathrm{ME}$ & - & Hexapoda, Megaloptera \\
\hline 12) & - & Hexapoda, Trichoptera \\
\hline DO & - & Hexapoda, Diptera, Other \\
\hline DTA & - & Hexapoda, Diptera, Chironomidae, Tanypodinae \\
\hline DOR & - & Hexapoda, Diptera, Chironomidae, Orthocladiinae \\
\hline $\mathrm{DCC}$ & - & Hexapoda, Diptera, Chironomidae, Chironomini \\
\hline DPC & - & Hexapoda, Diptera, Chironomidae, Pseudochironomini \\
\hline DTY & - & Hexapoda, Diptera, Chironomidae, Tanytarsini \\
\hline 19) & - & Hexapoda, Diptera, Diamesinae \\
\hline 20) & - & Hexapoda, Heteroptera \\
\hline LEP & - & Hexapoda, Lepidoptera \\
\hline 22) & - & Mollusca, Bivalvia \\
\hline MG & - & Mollusca, Gastropoda \\
\hline IAA & - & Isopoda, Asellidae \\
\hline
\end{tabular}

II. Functional Feeding Group Codes

$\begin{array}{llll}\text { 1) } & \text { CG } & - & \text { Collector/Gatherer } \\ \text { 2) } & \mathrm{CF} & - & \text { Collector/Filterer } \\ \text { 3) } & \mathrm{P} & - & \text { Predator } \\ \text { 4) } & \mathrm{SC} & - & \text { Scrapper } \\ \text { 5) } & \mathrm{SH} & - & \text { Shredder } \\ \text { 6) } & \mathrm{PH} & - & \text { Piercer/Herbivor } \\ \text { 7) } & \mathrm{O} & - & \text { Unidentified pupa }\end{array}$


III. Statistical Summary Abbreviations

$\begin{array}{rlll}\text { 1) } & \text { Bio. Index } & \text { - } & \text { North Carolina Biotic Index }=\frac{\text { Sum TVi NI }}{\text { Total N }} \\ \text { Where TVi }= & \text { Tolerance Values } \\ & \mathrm{Ni}= & \text { Number of Individuals of a Taxon and Total } \\ \mathrm{N}= & \text { Total Number of Individuals in the Sample } \\ & & & \text { Mean number of taxa per sampler } \\ \text { 2) } & \text { Mean Tax/Samp - } & \text { Total number of organisms for the station } \\ \text { 3) } & \text { Total Orgs. } & - & \text { Total number of taxa for the station } \\ \text { 4) } & \text { Tot. Tax } & - & \text { Total mean number of organisms per } \mathrm{m}^{2} \\ \text { 5) } & \text { Tot. Mean\# } & - & \text { - } \\ \text { 6) } & \text { FG } & - & \text { Functional group } \\ \text { 7) } & \text { Rel. Abd. } & - & \text { Relative abundance }\end{array}$




\begin{tabular}{|c|c|c|c|c|c|c|c|c|c|}
\hline sog & Trexon & TAXC & NCSA & FG & f(for Bin & Samplex Da & A & $B$ & $c$ \\
\hline 1 & 1 Hycreomina & AHC & \begin{tabular}{|r}
5.7 \\
\end{tabular} & & \begin{tabular}{|l|}
17.1 \\
\end{tabular} & & 1 & 2 & \\
\hline & 2 Gemmeridex & AMG & 8.9 & CG & 0 & & & & \\
\hline & 3 Ofiochente & ANO & B.2 & CG & 0 & & & & \\
\hline & 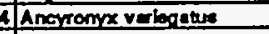 & co & 0.9 & CG & 48.3 & & 2 & 1 & \\
\hline & 5 Dineutusep. & $\mathrm{Co}$ & & & 0 & & & & \\
\hline 8 & G Ectoprla nerrose & co & 4.3 & sc & 0 & & & & \\
\hline & 7 Gonibinie diatrichl & co & & CG & 0 & & & & \\
\hline & 8 Mecronychice olebratus & co & 4.7 & CG & 4.7 & & & 1 & \\
\hline$\underline{9}$ & 9 Mkrocy loopes purilive & co & 2.1 & CG & 요 & & & & \\
\hline 10 & o Optionerves ep. & co & 2.7. & CG & 의 & & & & \\
\hline 11 & 1 Outimnive lativeculve & $c 0$ & 1.8 & CG & 1.8 & & & 1 & \\
\hline 12 & 2 Stordemis decorma & co & 5.4 & $C G$ & 0 & & & & \\
\hline 13 & 3 Stanatinis inusuts & co & 5.4 & CG & of & & & & \\
\hline 94 & A Stendinis epp. & Co & 5.4 & CG & 5.4 & & & 1 & \\
\hline 15 & 5 Comberides & DCA & 7.2 & $P+$ & 0 & & & & \\
\hline 16 & af Cryptoctironomus epp. & DCC & 6.7 & & of & & & & \\
\hline 17 & 7 Dicrotondipos spp. & DCC & 7.9 & CG & of & & & & \\
\hline & a Microtandipee rydoloneis & Dacc & 8.2. & CG & 요 & & & & \\
\hline 19 & 9 Microtondipos epp. & DoCC & 6.2 & CG & of & & & & \\
\hline 20 & o Nolotheuma bobiyi & DCC & 5.5 & CG & 22 & & & 3 & 1 \\
\hline 21 & 1) Phoonopeoctra flavipes & DCC & 8.5 & CG & 17 & & 2 & & \\
\hline 22 & 2 Pohypodtum fallax & DCC & 8.7 & $\mathrm{SH}$ & 20.1 & & & & \\
\hline 23 & Johypedilum spp. & DCC & 0.9 & CG & 69 & & 2 & 1 & 3. \\
\hline 24 & A Stolachomyle perputetra & $\overline{D C C}$ & 4.6 & $\mathrm{SH}$ & 4.6 & & 1 & & \\
\hline 25 & 5 Stonochironomuie ep. & DCC & 0.4 & $\mathrm{SH}$ & of & & & & \\
\hline 28 & g Tribolos poundum & JOCC & 0.6 & CG & of & & & & \\
\hline 27 & 7 Dismesini genus $P$ & DD & 7.4 & CG & a & & & & \\
\hline 28 & 8 Potthostia longmens & DO & 7.4 & CG & 0 & & & & \\
\hline 29 & 9 Atherbx lantha & Do & 2.1 & $p$ & of & & & & \\
\hline 30 & - Coratopogonid so & DO & 8.5 & & of & & & & \\
\hline 31 & 1 Choffera spp. & DO & 8.1 & CG & 18.2 & & 1 & & \\
\hline 32 & 2 Hemerodkomin spp. & DO & 8.1 & CG & 291.6 & & 12 & 8) & 1 \\
\hline 33 & S simultem egp. & DO & 4.4 & CF & 88 & & 14 & 8) & \\
\hline 34 & 4) Britha floviftons & DOR & 5.2 & SHH & of & & & & \\
\hline 35 & 5 Corynonouraspp. & DOA & 0.2 & CG & 8.2 & & & 1 & I \\
\hline 36 & 8 Cricotopus/Ortho spp. & DOR & 8.8 & CG & 132 & & 1 & 8 & 3 \\
\hline 37 & 7 Eukiofforials spo. & DOA & 5.7 & CG & of & & & & \\
\hline 39 & 9 Nonoclodilis epp. & DOA & 7.2 & CG & of & & & & \\
\hline 39 & Orthodod ius Fonioolo & DOA & 5.4 & SH & of & & & & \\
\hline 10 & Perokbifieribls Ep.1 & DOR & 5.9 & CG & 5.9 & & & 1 & t \\
\hline 41 & Peremetriocnomus cp. & DOR & 3.7 & CG & 33.3 & & & 5) & 4) \\
\hline 42 & 2 Peoctrocladius sp. & DOR & 3.8 & CG & 0 & & & & \\
\hline 43 & Aheocriootopus: spp. & DOR & 7.3 & CG & 1335.9 & & 24 & 70) & 53 \\
\hline 14 & if Synorthocled live somivitons & DOA & 4.7 & CG & 0 & & & & \\
\hline 45 & 5 Thionomancialle spo. & DOR & & CG & 72 & & 2 & (3) & (3) \\
\hline 46 & Tyetenta spp. & DOR & 3.9 & CG & 74.1 & & 4 & 7 & 6) \\
\hline 47 & Unisto multivirgas & DOA & 의 & CG & of & & & & \\
\hline 48 & 8 Xylopueper & DOR & 6.6 & SH & of & & & & \\
\hline 49 & Ablaboem mis spp. & DTA & 6.4 & & of & & & & \\
\hline 50 & of Chinotanypus pinoxis & DTA & 9.1 & $P$ & of & & & & \\
\hline 51 & Conchopolopia epp. & DTA & 8.7 & $P$ & 69.6 & & 1 & 3) & 3 \\
\hline 52 & 2 Lobrundinia spp. & DTA & 6 & $P$ & of & & & & \\
\hline 53 & 3 Naterela ep.A & DTA & 10 & $\bar{p}$ & of & & & & \\
\hline 54 & A Netotenypus spp. & DTA & 4 & $P$ & 4 & & & & 1 \\
\hline 55 & Persmering sp. & DTA & 2.8 & p & of & & & & \\
\hline 58 & 8 Pentaneure inconspioula & DTY & 4.6 & $P$ & 0 & & & & \\
\hline 57 & 7 inhootenytereus cpp. & DTY & 8.4 & CF & 313.6 & & 7 & 18 & 18 \\
\hline 58 & 8. Stompolina spp. & DTY & 2 & CG & of & & & & 1 \\
\hline 59 & 9 Tenytereses spp. & DTY & 8.7 & CG & 698.8 & & 15 & 37 & 27 \\
\hline 80 & Acorponne pyemoous & EP & 3.7 & CG & of & & & & \\
\hline 61 & 1 Bootis spp. & EP & 5.4 & CG & 64.8 & & 4 & 3 & \\
\hline 62 & 2 Csonis egp. & EP & 7.6 & CG & of & & & & \\
\hline 63 & 3 Eurylopholas spe. & EPP & 3 & CG & of & & & & \\
\hline 64 & Hoptegoria spp. & EP & 2.8 & sc & of & & & & \\
\hline 05 & 5 Áoopphomera youngi & EPP & 2.1 & CG & 0 & & & & \\
\hline 60 & a Praboptophiobia epp. & EP & 1.2 & CG & of & & & & \\
\hline 67 & 7 St Stononoms epp. & EP & 3.4 & sc & 47.6 & & 4 & 3 & \\
\hline 69 & g| Tricorythodes spp. & EF & 5.4 & CG & of & & & & \\
\hline 69 & 9 Corydehus cornutus & ME & 5.6 & $P$ & 11.2 & & & 2 & \\
\hline 70 & of Nigrania serticornis & ME & 5.5 & $P$ & 의 & & & & \\
\hline 71 & 1 Sialis spp. & ME & 7.5 & $\mathbf{P}$ & of & & & & \\
\hline 72 & 2 Ferricais sp. & MG & 6.9 & sc & of & & & & \\
\hline 73 & $\begin{array}{l}3 \text { Boyeria vinose } \\
\end{array}$ & 100 & 8.3 & $P$ & of & & & & \\
\hline 74 & 4) Coonoogrionidoo & $10 D$ & 9 & $P$ & of & & & & \\
\hline 75 & $5 /$ Acronourla sbnormis & $P_{2}$ & 2.2 & $P$ & of & & & & \\
\hline 76 & 6 Acronouria erenose & $P_{2}$ & 2.2 & $P$ & 2.2 & & & & \\
\hline 77 & 7 Acronourta hycories & $P L$ & 1.5 & $p$ & 7.5 & & & & 4 \\
\hline 78 & a Acronouria mola & $P L$ & 0.9 & $p$ & 3.6 & & 1 & (3) & \\
\hline 79 & 9 Acronourio spg. & $P_{2}$ & 1.4 & $P$ & 1.4 & & & & \\
\hline 80 & of Aanotina spp. & $P L$ & 0 & $P$ & of & & & & \\
\hline 81 & 1 Allocopoia epp. & $\frac{P}{P}$ & 2.8 & SH & 5.6 & & & & \\
\hline 82 & 2 Holopious sp. & PL & 0.4 & $P$ & of & & & & \\
\hline 83 & 3 leoperla spp. & $P L$ & 2 & $\mathbf{P}$ & of & & & & \\
\hline 84 & 4) Pregentino kensansis & $P$ & 2 & $P$ & of & & & & \\
\hline 85 & 5 Perogentins spp. & $P L$ & 2 & $P$ & of & & & & \\
\hline B日 & E Porleste cpp. & $P L$ & 0 & $\bar{p}$ & of & & 1 & 2 & \\
\hline & 7 Perlinallo aphyre & IPL & of & $P$ & of & & & & \\
\hline 88 & 8) Perlinalla spp. & IPL & 의 & IP & 의 & & & & \\
\hline
\end{tabular}




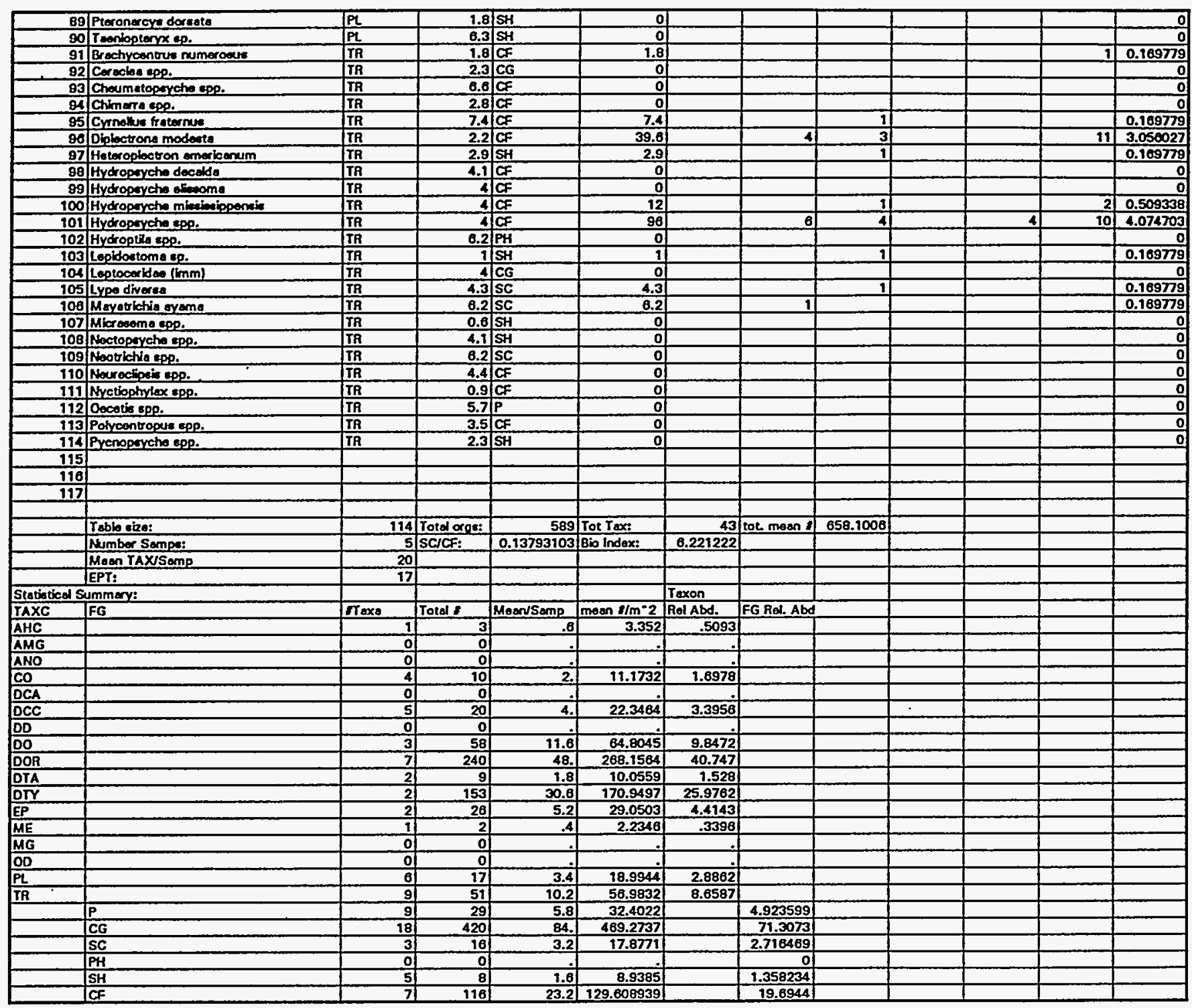




\section{UTR BANKS MILĹ RD 08/19/93 STATION 1}

\begin{tabular}{|l|}
\hline Taxa List: \\
\hline Hydracarina \\
\hline Ancyronyx variegatus \\
\hline Macronychus glabratus \\
\hline Oulimnius latiusculus \\
\hline Stenelmis spp. \\
\hline Nilothauma babiyi \\
\hline Phaenopsectra flavipes \\
\hline Polypedilum fallax \\
\hline Polypedilum spp. \\
\hline Stelechomyia perpulchra \\
\hline Chelifera spp. \\
\hline Hemerodromia spp. \\
\hline Simulium spp. \\
\hline Corynoneura spp. \\
\hline Cricotopus/Ortho spp. \\
\hline Parakiefferiella sp.1 \\
\hline Parametriocnemus sp. \\
\hline Rheocricotopus spp. \\
\hline Thienemanniella spp. \\
\hline Tvetenia spp. \\
\hline Conchapelopia spp. \\
\hline Nilotanypus spp. \\
\hline Rheotanytarsus spp. \\
\hline Tanytarsus spp. \\
\hline Baetis spp. \\
\hline Stenonema spp. \\
\hline Corydalus cornutus \\
\hline Acroneuria arenosa \\
\hline Acroneuria lycorias \\
\hline Acroneuria mela \\
\hline Acroneuria spp. \\
\hline Allocapnia spp. \\
\hline Perlesta spp. \\
\hline Brachycentrus numerosus \\
\hline Cyrnellus fraternus \\
\hline Diplectrona modesta \\
\hline Heteroplectron americanum \\
\hline Hydropsyche mississippensis \\
\hline Hydropsyche spp. \\
\hline Lepidostoma sp. \\
\hline Lype diversa \\
\hline Mayatrichia ayama \\
\hline
\end{tabular}




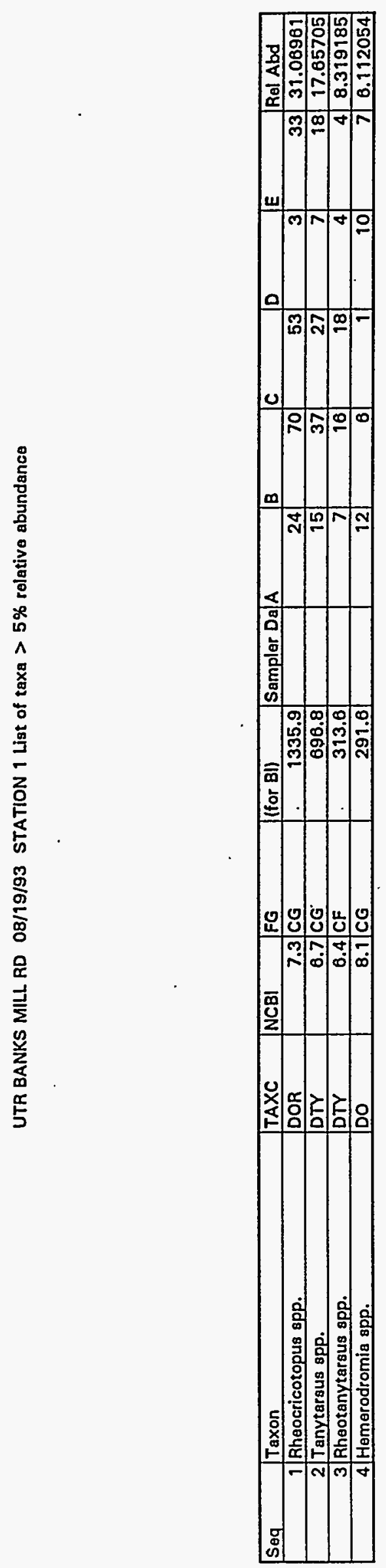




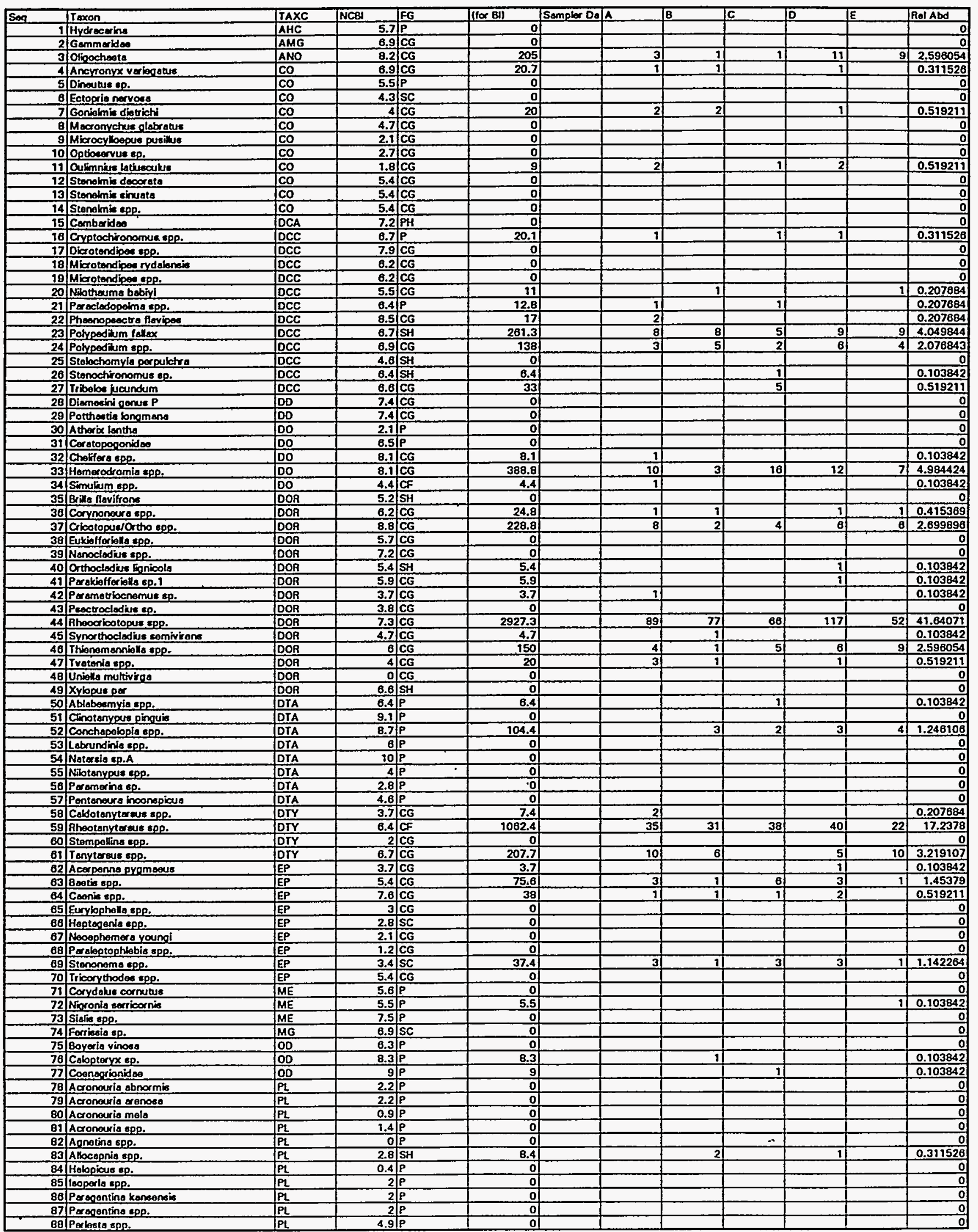




\begin{tabular}{|c|c|c|c|c|c|c|c|c|c|c|c|c|}
\hline 89 & Pertinalle ophye & $\overline{\mathbf{P} L}$ & 0 & TP & 0 & & & & & & & 0 \\
\hline 90 & Perlinolls spp. & PL. & o & $\bar{p}$ & 0 & & & & & & & 의 \\
\hline 91 & Pteronercye dorcata & $\mathbf{P L}$ & 1.8 & $\overline{S H}$ & o & & & & & & & ? \\
\hline 92 & Toonioptaryx eg. & $\overline{P L}$ & 6.3 & SH & o & & & & & & & 의 \\
\hline 93 & Brechycentrue numeroous & TR & 1.8 & CF & 0 & & & & & & & 의 \\
\hline 94 & Coraclas spp & TR & 2.3 & CG & 4.6 & & & & & & 2 & 0.207684 \\
\hline 95 & Cheumatopayche spp. & TR & 6.6 & CF & 33 & & & & 4 & & 1 & 0.519211 \\
\hline 90 & Chimerta epp. & $\overline{T R}$ & 2.8 & $C F$ & 5.6 & & & & 1 & & 1 & 0.207684 \\
\hline 97 & Cynnolkus fraternus & Th & 7.4 & CF & 44.4 & & 1 & 1 & & 4 & & 0.623053 \\
\hline 98 & Diploctrone modosta & TR & 2.2 & CF & 44 & & 4 & 3 & 7 & 5 & 1 & 2.076843 \\
\hline 99 & Hydroperyche decolde & Th & 4.1 & CF & 0 & & & & & & & 0 \\
\hline 100 & Hydropsyche oliosema & If & 4 & CF & 0 & & & & & & & 의 \\
\hline 101 & Hydroperche mististipponsis & IR & 4 & CF & 0 & & & & & & & 의 \\
\hline 102 & Hydropeycho epp. & IR & 4 & CF & 128 & & 2 & & 10 & 15 & 5 & 3.322949 \\
\hline 103 & Hydroptila spp. & TR & 6.2 & $\mathrm{PH}$ & 99.2 & & & 14 & 1 & 1 & & 1.861475 \\
\hline 104 & Leptocaridee (imm) & TR & 4 & $\mathbf{C G}$ & 0 & & & & & & & 0 \\
\hline 105 & Lype diverea & TR & 4.3 & SC & 8.6 & & & 1 & i) & & & 0.207684 \\
\hline 108 & Moyatrichia oyama & In & 6.2 & Sc & 6.2 & & & 1 & & & & 0.103842 \\
\hline 107 & Mioroseme epp. & TR & 0.6 & SH & 0 & & & & & & & 의 \\
\hline 108 & Noctopeycho epp. & $T$ TR & 4.1 & SH & 0 & & & & & & & 의 \\
\hline 109 & Nooblichis spp. & TR & 6.2 & SC & of & & & & & & & 의 \\
\hline 110 & Noureclipeis spp. & IT & 4.4 & CF & 0 & & & & & & & 의 \\
\hline 111 & Nyctiophylax epp. & IR & 0.9 & CF & 0 & & & & & & & 0 \\
\hline 112 & Oocatis Epp. & IR & 5.7 & $P$ & 5.7 & & 1 & & & & & 0.103842 \\
\hline 113 & Polycentropus spp. & TR & 3.5 & $C F$ & 0 & & & & & & & 0 \\
\hline 114 & Pycnopsycho spp. & In & 2.3 & SH & of & & & & & & & 의 \\
\hline 115 & & & & & & & & & & & & \\
\hline 118 & & & & & & & & & & & & \\
\hline 117 & & & & & & & & & & & & \\
\hline 118 & & & & & & & & & & & & \\
\hline 119 & Tobla oizo: & 114 & Total $\alpha$ og: & 963 & Tot Tex: & 47 & tol. moan 4 & 1075.978 & & & & \\
\hline 120 & Number Samps: & 5 & SCICF: & 0.08034483 & Bio Index: & 6.72866 & & & & & & \\
\hline 121 & Mean TAXISamp & 25.2 & & & & & & & & & & \\
\hline 122 & EPT: & 15 & & & & & & & & & & \\
\hline Stetiatical S & ummery: & & & & & Taxon & & & & & & \\
\hline TAXC & FG & ITaxa & Total : & Mean/Semp. & $\operatorname{masn} 8 / \mathrm{m}^{*} 2$ & Re! Abd. & FG Rol. Abd & & & & & \\
\hline AHC & & 0 & 0 & & & & & & & & & \\
\hline AMG & & 0 & of & & & & & & & & & \\
\hline ANO & & 1 & 25 & 5. & 27.933 & 2.5981 & & & & & & \\
\hline CO & & 3 & 13 & 2.6 & 14.5251 & 1.3499 & & & & & & \\
\hline$\overline{D C A}$ & & 0 & 의 & & & & & & & & & \\
\hline DCC & & 8 & 74 & 14.8 & 82.6818 & 7.6843 & & & & & & \\
\hline DD & & 0 & 0 & & & & & & & & & \\
\hline DO & & 3 & 50 & 10. & 55.8659 & 5.1921 & & & & & & \\
\hline DOA & & 9 & 465 & 93.1 & 519.5531 & 48.2808 & & & & & & \\
\hline DIA & & 2 & 13 & 2.8 & 14.5251 & 1.3499 & & & & & & \\
\hline DTY & & 3 & 199 & 39.8 & 222.3464 & $20.664 \theta$ & & & & & & \\
\hline$E P$ & & 4 & 31 & 6.2 & 34.8369 & 3.2191 & & & & & & \\
\hline ME & & 1 & 1 & .2 & 1.1173 & .1038 & & & & & & \\
\hline MG & & 0 & of &. & & & & & & & & \\
\hline 00 & & 2 & 2 & .4 & 2.2348 & .2077 & & & & & & \\
\hline$\overline{P L}$ & & 1 & 3 & .8 & 3.352 & .3115 & & & & & & \\
\hline If & & 10 & 87 & 17.4 & 97.2067 & 9.0343 & & & & & & \\
\hline & $P$ & 8 & 22 & 4.4 & 24.581 & & 2.284528 & & & & & \\
\hline & CG & 24 & 635 & 127. & 709.4972 & & 65.93977 & & & & & \\
\hline & sc & 3 & 14 & 2.8 & 15.6425 & & 1.45379 & & & & & \\
\hline & $\mathrm{PH}$ & 1 & 16 & 3.2 & 17.8771 & & 1.661475 & & & & & \\
\hline & SH & 4 & 44 & 8.8 & 49.162 & & 4.569055 & & & & & \\
\hline & ICF & 7 & 232 & 46.4 & 259.217877 & & 24.09138 & & & & & \\
\hline
\end{tabular}




\begin{tabular}{|l|}
\hline Taxa List: \\
\hline Oligochaeta \\
\hline Ancyronyx variegatus \\
\hline Gonielmis dietrichi \\
\hline Oulimnius latiusculus \\
\hline Cryptochironomus spp. \\
\hline Nilothauma babiyi \\
\hline Paracladopelma spp. \\
\hline Phaenopsectra flavipes \\
\hline Polypedilum fallax \\
\hline Polypedilum spp. \\
\hline Stenochironomus sp. \\
\hline Tribelos jucundum \\
\hline Chelifera spp. \\
\hline Hemerodromia spp. \\
\hline Simulium spp. \\
\hline Corynoneura spp. \\
\hline Cricotopus/Ortho spp. \\
\hline Orthocladius lignicola \\
\hline Parakiefferiella sp.1 \\
\hline Parametriocnemus sp. \\
\hline Rheocricotopus spp. \\
\hline Synorthocladius semivirens \\
\hline Thienemanniella spp. \\
\hline Tvetenia spp. \\
\hline Ablabesmyia spp. \\
\hline Conchapelopia spp. \\
\hline Caldotanytarsus spp. \\
\hline Rheotanytarsus spp. \\
\hline Tanytarsus spp. \\
\hline Acerpenna pygmaeus \\
\hline Baetis spp. \\
\hline Caenis spp. \\
\hline Stenonema spp. \\
\hline Nigronia serricornis \\
\hline Calopteryx sp. \\
\hline Coenagrionidae \\
\hline Allocapnia spp. \\
\hline Ceraclea spp \\
\hline Cheumatopsyche spp. \\
\hline Chimarra spp. \\
\hline Cyrnellus fraternus \\
\hline Diplectrona modesta \\
\hline Hydropsyche spp. \\
\hline Hydroptila spp. \\
\hline Mayatrichia ayama \\
\hline
\end{tabular}




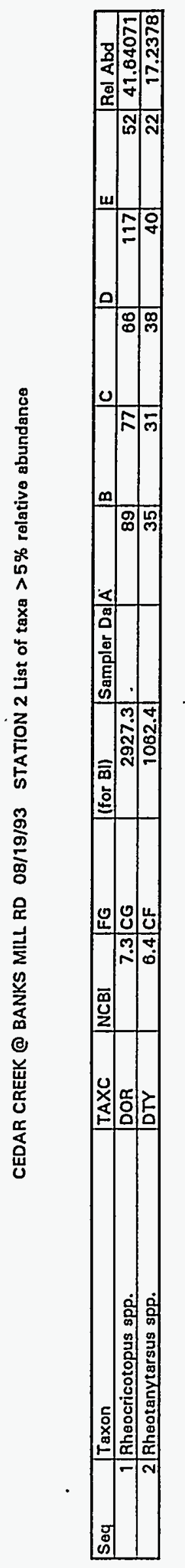




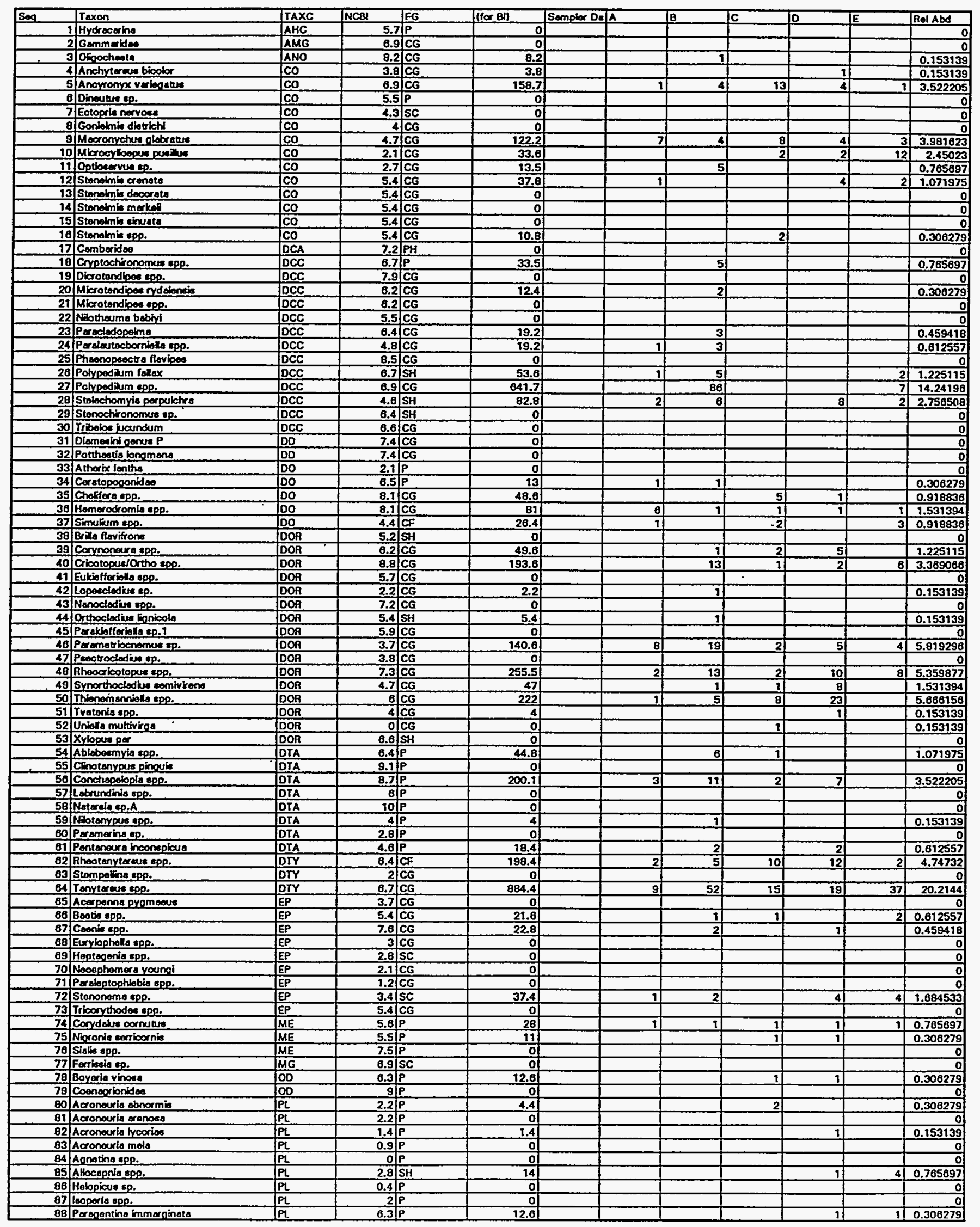




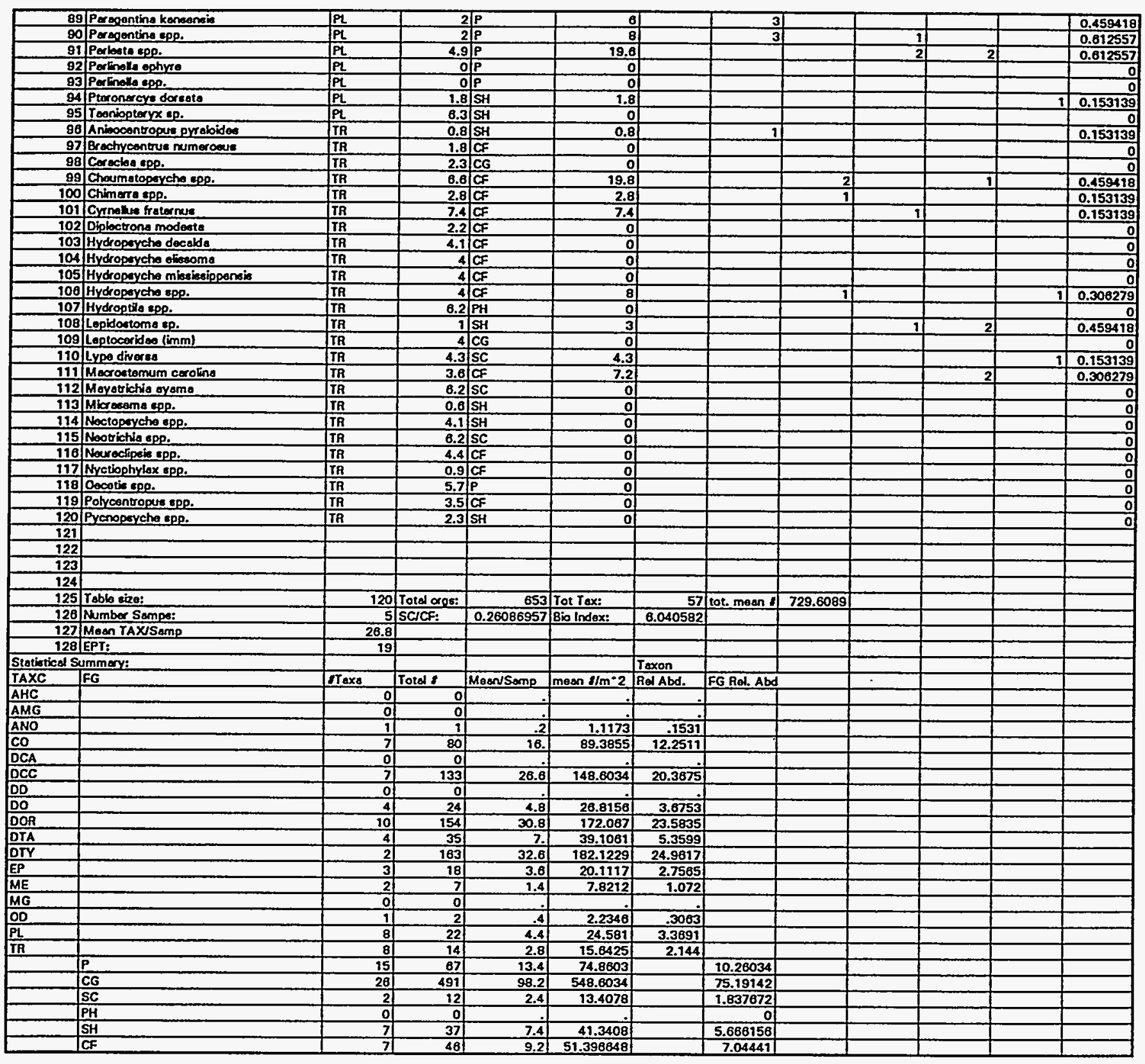




\section{BOGGY GUT @ Rd 781.4 8/19/93 STATION 3}

\begin{tabular}{|l|}
\hline Taxa List: \\
\hline Oligochaeta \\
\hline Arichytarsus bicolor \\
\hline Ancyronyx variegatus \\
\hline Macronychus glabratus \\
\hline Microcylloepus pusillus \\
\hline Optioservus sp. \\
\hline Stenelmis crenata \\
\hline Stenelmis spp. \\
\hline Cryptochironomus spp. \\
\hline Microtendipes rydalensis \\
\hline Paracladopelma \\
\hline Paralautecborniella spp. \\
\hline Polypedilum fallax \\
\hline Polypedilum spp. \\
\hline Stelechomyia perpulchra \\
\hline Ceratopogonidae \\
\hline Chelifera spp. \\
\hline Hemerodromia spp. \\
\hline Simulium spp. \\
\hline Corynoneura spp. \\
\hline Cricotopus/Ortho spp. \\
\hline Lopescladius sp. \\
\hline Orthocladius lignicola \\
\hline Parametriocnemus sp. \\
\hline Rheocricotopus spp. \\
\hline Synorthocladius semivirens \\
\hline Thienemanniella spp. \\
\hline Tvetenia spp. \\
\hline Uniella multivirga \\
\hline Ablabesmyia spp. \\
\hline Conchapelopia spp. \\
\hline Nilotanypus spp. \\
\hline Pentaneura inconspicua \\
\hline Rheotanytarsus spp. \\
\hline Tanytarsus spp. \\
\hline Baetis spp. \\
\hline Caenis spp. \\
\hline Stenonema spp. \\
\hline Corydalus cornutus \\
\hline Nigronia serricornis \\
\hline Boyeria vinosa \\
\hline Acroneuria abnormis \\
\hline Acroneuria lycorias \\
\hline Allocapnia spp. \\
\hline Paragentina immarginata \\
\hline Paragentina kansensis \\
\hline Paragentina spp. \\
\hline Perlesta spp. \\
\hline
\end{tabular}


BOGGY GUT @ Rd 781.4 8/19/93 STATION 3

Pteronarcys dorsata

Anisocentropus pyraloides

Cheumatopsyche spp.

Chimarra spp.

Cyrnellus fraternus

Hydropsyche spp.

Lepidostoma sp.

Lype diversa

Macrostemum carolina 


\begin{tabular}{|c|c|c|c|c|c|c|c|c|c|c|c|}
\hline Seq & Taxon & TAXC & NCBI & $F G$ & (for $\mathrm{BI})$ & \begin{tabular}{|l|l|} 
Samplar Da \\
\end{tabular} & B & $c$ & D & $E$ & Rol Abd \\
\hline 1 & Tanytarsus spp. & DTY & 6.7 & CG & 884.4 & 9 & 52 & 15 & 19 & 37 & 20.2144 \\
\hline 2 & Polypedilum spp. & DCC & 6.9 & CG & 641.7 & & 86 & & & 7 & 14.24198 \\
\hline 3 & Parametriocnemus sp. & DOR & 3.7 & CG & 140.6 & 8 & 19 & 2 & 5 & 4 & 5.819298 \\
\hline 4 & Thienemenniella spp. & DOR & & CG & 222 & 1 & 5 & 8 & 23 & & 5.868156 \\
\hline & Rheocricotopus spp. & DOR & 7.3 & $\overline{C G}$ & 255.5 & 2 & 13 & 2 & 10 & 8 & 5.359877 \\
\hline
\end{tabular}




\begin{tabular}{|c|c|c|c|c|c|c|c|c|c|}
\hline Sog. & Taxon & IAXC & NCBS & FG & $(f \circ x$ Bn $)$ & Sompler Da & A & B & c \\
\hline 1 & Hydrocerins & AHC & 5.7 & $7 \mathrm{P}$ & of & & & & \\
\hline 2 & 2) Gammerides & AMG & 8.9 & CG & of & & & & \\
\hline 3 & OFochoota & ANO & 8.2 & $\mathbf{C G}$ & of & & & & \\
\hline 4 & Ancyonyx veriogatuse & co & 6.9 & $\mathbf{C G}$ & 13.8 & & 2. & & \\
\hline 5 & 5 Dinouture ep. & $\mathrm{CO}$ & 5.5 & S/P & of & & & & \\
\hline 6 & Ectopria nervosa & co & 4.3 & SC & of & & & & \\
\hline$\overline{7}$ & Gonialmis diartich & Co & 4 & CG & 24 & & i) & 2 & \\
\hline$\underline{8}$ & Mecronychue glabratue & $\mathrm{CO}$ & 4.7 & CG & 14.1 & & & & 3 \\
\hline 9 & Dicrocyloopus pustithes & Co & 2.1 & CG & of & & & & \\
\hline 10 & Optiocervue ep. & co & 2.7 & CG & 2.7 & & & 1 & \\
\hline 11 & Stonoimis cronate & co & 5.4 & CG & 5.4 & & 1 & & \\
\hline 12 & Standmis decorata & co & 5.4 & CG & of & & & & \\
\hline 13 & Stonokmis tinusute & co & 5.4 & $\mathrm{CG}$ & of & & & & \\
\hline 14 & Stanaknis spe. & co & 5.4 & CG & 5.4 & & & & \\
\hline 15 & Camberidos & JDCA & 7.2 & $\mathrm{PH}$ & of & & & & \\
\hline 16 & Cryploctironomue upo. & DCC & 8.7 & $P$ & 33.5 & & 3 & 1 & \\
\hline 17 & Dicrotandipas spe. & Docc & 7.9 & CG & of & & & & \\
\hline 10 & Microtondipes rydalansis & DCC & 8.2 & CG & of & & & & \\
\hline 19 & Milarotandipos spp. & DCC & 8.2 & $\overline{C G}$ & of & & & & \\
\hline 20 & Nobotheuma bobiyi & DCC & 5.5 & CG & 10.5 & & & 2 & \\
\hline 21 & Phoenopectra flevipos & DCC & 8.5 & $\overline{C G}$ & 8.5 & & & & \\
\hline 22 & Polypedium follax & DocC & 6.7 & SH & 100.5 & & 9 & 1 & \\
\hline 23 & Polypodium spp. & DCC & 6.9 & CG & 414) & & 16 & 15 & 10 \\
\hline 24 & IStelochom rie perpuletra & DCC & 4.6 & SH & 38.8 & & 1) & 3 & 1 \\
\hline 25 & Stanochironomese sp. & DOCC & 6.4 & SH & 6.4 & & & 1 & \\
\hline 20 & Tribolos luoundum & DCC & 6.6 & CG & 0 & & & & \\
\hline 27 & Dismesini ganuse $P$ & DD & 7.4 & CG & o) & & & & \\
\hline 28. & Potthestia longmona & DD & 7.4 & $\mathrm{CG}$ & of & & & & \\
\hline 29 & A Athor bx lanthe & DO & 2.1 & P & 0 & & $T$ & & \\
\hline 30 & Coratopgoonideo & DO & 6.5 & $\bar{p}$ & 6.5 & & 1 & & \\
\hline 31 & Cheffora spp. & 100 & 8.1 & CG & 8.1 & & 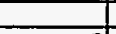 & & 1 \\
\hline 32 & Homerodramio epe. & DO & 8.1 & CG & 243 & & 5) & 8) & 3 \\
\hline 33 & Simulum spg. & DO & 4.4 & CF & 8.8 & & & 2 & \\
\hline 34 & Billa favifrons & DOR & 5.2 & SH & 5.2 & & & & 9 \\
\hline 35 & Corynonours spp. & DOR & 6.2 & CG & 88.8 & & 3. & 8 & 2 \\
\hline 36 & Cricolopue/Ortho epp. & DOR & 8.8 & CG & 387.2 & & 41 & g) & 8 \\
\hline 37 & Eukiafforiaka spe. & DOR & 5.7 & CG & of & & & & \\
\hline 38 & Nanoclodive epp. & DOR & 7.2 & CG & of & & & & \\
\hline 39 & Orthocladiue Foniools & DOR & 5.4 & SH & of & & & & \\
\hline 40 & Perakiofferiolla sp.1 & DOR & 5.9 & $\overline{C G}$ & of & & & & \\
\hline 41 & Peramotiocnomus ep. & DOR & 3.7 & CG & 18.5 & & & 4 & \\
\hline 42 & Proctrocledive ip. & DOR & 3.8 & CG & of & & & & \\
\hline 43. & Rhoocrioolopus spp. & JOOR & 7.3 & CG & 430.7 & & 4 & 26 & 18) \\
\hline 44 & Symorthoclodius comivirens & TOR & 4.7 & CG & 131.6 & & 5 & 6) & 8 \\
\hline 45 & Thionemsnniolls spp. & DOR & 6 & CG & 648 & & 15 & 40 & 35 \\
\hline 46 & Traterie spp. & DOR & 4 & CG & 40 & & & 2 & 2 \\
\hline 47 & Uniallo multivirgo & DOR & 은 & CG & of & & & - & - \\
\hline 48 & Xylopueper & DOR & 8.8 & SH & 0 & & & & \\
\hline 49 & Ablaboamyia spp. & OTA & 8.4 & P & of & & & & \\
\hline 50 & Clinotenypue pinouis & DTA & 9.1 & $\bar{p}$ & of & & & & \\
\hline 51 & Conchspolopio spp. & DrA & 8.7 & $\bar{P}$ & 382.8 & & 3 & 19 & 4 \\
\hline 52 & Labnundinis spp. & DTA & 6 & $P$ & of & & & & \\
\hline 53 & Natersia sp.A & DTA & 10 & $P$ & of & & & & \\
\hline 54 & Ninotanypus spp. & DTA & 4 & P & 0 & & & & \\
\hline 55 & Poramerina sp. & DTA & 2.8 & $\mathbf{P}$ & of & & & & \\
\hline 58 & Pentanoera inconspiaun & DTA & 4.8 & $\bar{p}$ & of & & & & \\
\hline 57) & Rhootenytereus sog. & DTY & 6.4 & CF & 185.6 & & $\mathbf{3}$ & 15 & 3) \\
\hline 58 & Stempelfirs spe. & DTY & 2 & CG & of & & & & 4 \\
\hline 59 & Tenptereve sop. & DTY & 6.7 & CG & 757.1 & & 11 & 35 & 9 \\
\hline$\infty$ & Acorpanns pyomoous & EP & 3.7 & ICG & 0 & & & & \\
\hline 61 & Bootis spp. & EP & 5.4 & CG & 21.6 & & 2 & 1 & \\
\hline 62 & Coonis egp. & EP & 7.8 & $\overline{C G}$ & 0 & & & & \\
\hline 63 & Eurybophella spp. & EP & 3) & CG & of & & & & \\
\hline 64 & Heptegenis spp. & EP & 2.8 & sc & of & & & & \\
\hline 05 & Nooephemera youngi & EP & 2.1 & CG & of & & & & \\
\hline 68) & Peroloptophlabia spp. & EP & 1.2 & CG & of & & & & \\
\hline 67 & Stononama spe. & EP & 3.4 & SC & 27.2 & & 4 & & 1 \\
\hline 68) & Tricorythodes epp. & EP & 5.4 & CG & of & & & & \\
\hline 69: & Corydaks corrutere & ME & 5.8 & $P$ & 5.6 & & 1 & & \\
\hline 70 & Nigronla serriconnis & ME & 5.5 & $\mathbf{P}$ & of & & & & \\
\hline 71 & Sialie spp. & $M E$ & 7.5 & $\mathbf{P}$ & of & & & & \\
\hline 72 & Ferriseia ep. & MG & 6.9 & SC & 0 & & & & \\
\hline 73 & Boyerio vinose & 100 & 6.3 & $\mathbf{P}$ & 12.6 & & & & 1 \\
\hline 74 & Coengorionides & 100 & 9 & $\bar{P}$ & of & & & & \\
\hline 75 & Acronourla abnormis & $P L$ & 2.2 & $P$ & of & & & & \\
\hline 78 & Acronourle orenosa & $\overline{P L}$ & 2.2 & P & 0 & & & & \\
\hline 77 & Acroneuris lycorlos & $P L$ & 1.5 & $p$ & 84 & & 8 & 8 & 13 \\
\hline 70 & Acronauris meis & PL & 0.9 & $\mathbf{P}$ & of & & & & \\
\hline 79 & Acnoting spp. & $P L$ & of & $p$ & of & & & & \\
\hline BO & Allocepnia epp. & $P L$ & 2.8 & SH & 8.4 & & 2 & & 1 \\
\hline Bi & Helopians sp. & PL. & 0.4 & $\mathbf{P}$ & of & & & & \\
\hline 82 & leoperla spp. & PLL & 2 & $P$ & o & & & & \\
\hline 83 & Poropentina kencensis & $\overline{P L}$ & 2 & $P$ & of & & & & \\
\hline 84 & Porogentina spp. & $P L$ & 2 & P & of & & & & \\
\hline 85 & Perlosta cpp. & PL & 4.9 & $P$ & 39.2 & & 5 & 2 & \\
\hline 86 & Perlinolla ephyre & $P L$ & of & $P$ & of & & & & \\
\hline 87 & Perlinollo spp. & $P t$ & 0 & $P$ & 이 & & & & \\
\hline 88 & Pitoronercye dorsata & $\overline{P L}$ & 1.8 & $\mathrm{SH}$ & ol & & & & \\
\hline
\end{tabular}




\begin{tabular}{|c|c|c|c|c|c|c|c|c|c|c|c|c|}
\hline 89 & Tooniopteryx ap. & $P L$ & 6.3 & SSH & of & & & & & & & $\underline{0}$ \\
\hline 80 & Anieocentropus pyreloider & ITR & 0.8 & SH & 0,8 & & & & & 1 & & 0.137552 \\
\hline 91 & Brechyocentrue numeroevs & TrR & 1.8 & CF & of & & & & & & & 0 \\
\hline 82 & Cerselas spp. & Th & 2.3 & ICG & of & & & & & & & 0 \\
\hline 83 & Cheumatoperyche epp. & ITR & 0.6 & CF & 13.2 & & 2 & & & & & 0.275103 \\
\hline 94 & Chimerta epp. & TR & 2.8 & $C$ & 2.8 & & 1 & & & & & 0.137552 \\
\hline 85 & Cynollus fraternue & IR & 7.4 & CF & 59.2 & & 1 & 5 & 2 & & & 1.100413 \\
\hline 96 & Diploctrone modente & IR & 2.2 & CF & 11. & & 2 & & 1 & & 2 & 0.687758 \\
\hline 97 & Hydropeych deoedde & IR & 4.1 & $C F$ & of & & & & & & & 0 \\
\hline 98 & Hydroperyche erimeoms & Th & 4 & $C F$ & of & & & & & & & 0 \\
\hline 90 & Hydroperyche miatielopenie & IR & 4 & CF & of & & & & & & & 0 \\
\hline 100 & Hydroperche spe. & Tra & 4 & CF & 104 & & 17 & & 3 & 1 & 5 & 3.576341 \\
\hline 101 & Hydroptio epp. & If & 6.2 & $\mathrm{PH}$ & of & & & & & & & 0 \\
\hline 102 & Leptoceriden (imm) & Trs & 4 & CG & of & & & & & & & 0 \\
\hline 103 & Lype diveras & TR & 4.3 & sc & of & & & & & & & 0 \\
\hline 104 & Mecrontarnum zebratum & TA & 3.6 & CF & 7.2 & & t) & & & 1 & & 0.275103 \\
\hline 105 & Meyatrichio aremo & $T A$ & 6.2 & sc & of & & & & & & & 0 \\
\hline 108 & Milaresems app. & $T A$ & 0.6 & SH & 0.6 & & 1 & & & & & 0.137552 \\
\hline 107 & Noctopayche epp. & TR & 4.1 & SH & of & & & & & & & 0 \\
\hline 108 & Nootrichin spp. & TR & 6.2 & sc & of & & & & & & & 0 \\
\hline 109 & Houroclipoie epp. & TR & 4.4 & CF & 요 & & & & & & & 은 \\
\hline 110 & Nyctiophylax spe. & Th & 0.9 & CF & of & & & & & & & 0 \\
\hline 111 & Oocatin ipp. & ITR & 5.7 & $P$ & 11.4 & & & & & & 2 & 0.275103 \\
\hline 112 & Polycontropus ipp. & IR & 3.5 & CF & 3.5 & & & & & & 1 & 0.137552 \\
\hline 113 & Pycnoperche upp. & TR & 2.3 & SH & of & & & & & & & 0 \\
\hline 114 & & & & & & & & & & & & \\
\hline 115 & & & & & & & & & & & & \\
\hline 118 & & & & & & & & & & & & \\
\hline 117 & & & & & & & & & & & & \\
\hline 118 & Toble size: & 113 & Totd orge: & 727 & Tot Tax: & 45 & tot. mesn 1 & 812.2905 & & & & \\
\hline 119 & Number Sampe: & 5 & SCICF: & 0.10526316 & Bio Index: & 6.098762 & & & & & & \\
\hline 120 & Maen TAX/Samp & 23.8 & & & & & & & & & & \\
\hline 121 & IEPI: & 15 & & & & & & & & & & \\
\hline Siatisticel Su & unmery: & & & & & Toxon & & & & & & \\
\hline IAXC & FG & Taxa & Total $/$ & Moon/Samp & mean $1 / m^{-} 2$ & Pel Abd. & FG Rol. Abd & & & & & \\
\hline AHC & & of & of & & & & & & & & & \\
\hline AMG & & 의 & of & & & & & & & & & \\
\hline ANO & & 요 & of & & & & & & - & & & \\
\hline co & & (6) & 14 & 2.8 & 15.6425 & 1.9257 & & & & & & \\
\hline$D C A$ & & of & of & & & & & & & & & \\
\hline DCC & & 7 & 93 & 18.6 & 103.9108 & 12.7923 & & & & & & \\
\hline DD & & of & of & & . & & & & & & & \\
\hline DO & & 4 & 34 & 6.8 & 37.9888 & 4.6768 & & & & & & \\
\hline DOA & & 8 & 289 & 53.8 & 300.5587 & 37.0014 & & & & & & \\
\hline DTA & & 1 & 44 & 8.8 & 49.162 & 6.0523 & & & & & & \\
\hline DTY & & 2 & 142 & 28.4 & 158.6592 & 19.5323 & & & & & & \\
\hline EP & & 2 & 12 & 2.4 & 13.4078 & 1.6508 & & & & & & \\
\hline ME & & 1 & 1 & .2 & 1.1173 & .1378 & & & & & & \\
\hline MG & & of & of & 4 & & & & & & & & \\
\hline OD & & 1 & 2 & .4 & 2.2346 & .2751 & & & & & & \\
\hline$P L$ & & 3 & 87 & 13.4 & 74.8603 & 9.218 & & & & & & \\
\hline \multirow[t]{7}{*}{ IR } & & 10 & 49 & 9.8 & 54.7488 & 0.74 & & & & & & \\
\hline & $P$ & 8 & 119 & 23.8 & 132.9609 & & 16.36884 & & & & & \\
\hline & CG & 20 & 494 & 98.8 & 551.9553 & & 67.95048 & & & & & \\
\hline & sc & 1 & (8) & 1.6 & 8.9385 & & 1.100413 & & & & & \\
\hline & $\mathrm{PH}$ & of & of & .1 & if & & of & & & & & \\
\hline & SH & 7 & 30 & 8. & 33.5196 & & 4.126547 & & & & & \\
\hline & ICF & 9) & 78 & 15.2 & 84.9162011 & & 10.45392 & & & & & \\
\hline
\end{tabular}




\section{UTR @ RD 8-1 08/19/93 STATION 4}

\begin{tabular}{|l|}
\hline Taxa List: \\
\hline Ancyronyx variegatus \\
\hline Gonielmis dietrichi \\
\hline Macronychus glabratus \\
\hline Optioservus sp. \\
\hline Stenelmis crenata \\
\hline Stenelmis spp. \\
\hline Cryptochironomus spp. \\
\hline Nilothauma babiyi \\
\hline Phaenopsectra flavipes \\
\hline Polypedilum fallax \\
\hline Polypedilum spp. \\
\hline Stelechomyia perpulchra \\
\hline Stenochironomus sp. \\
\hline Ceratopogonidae \\
\hline Chelifera spp. \\
\hline Hemerodromia spp. \\
\hline Simulium spp. \\
\hline Brilla flavifrons \\
\hline Corynoneura spp. \\
\hline Cricotopus/Ortho spp. \\
\hline Parametriocnemus sp. \\
\hline Rheocricotopus spp. \\
\hline Synorthocladius semivirens \\
\hline Thienemanniella spp. \\
\hline Tvetenia spp. \\
\hline Conchapelopia spp. \\
\hline Rheotanytarsus spp. \\
\hline Tanytarsus spp. \\
\hline Baetis spp. \\
\hline Stenonema spp. \\
\hline Corydalus cornutus \\
\hline Boyeria vinosa \\
\hline Acroneuria lycorias \\
\hline Allocapnia spp. \\
\hline Perlesta spp. \\
\hline Anisocentropus pyraloides \\
\hline Cheumatopsyche spp. \\
\hline Chimarra spp. \\
\hline Cyrnellus fraternus \\
\hline Diplectrona modesta \\
\hline Hydropsyche spp. \\
\hline Macrostemum zebratum \\
\hline Micrasema spp. \\
\hline Oecetis spp. \\
\hline olycentropus spp. \\
\hline
\end{tabular}




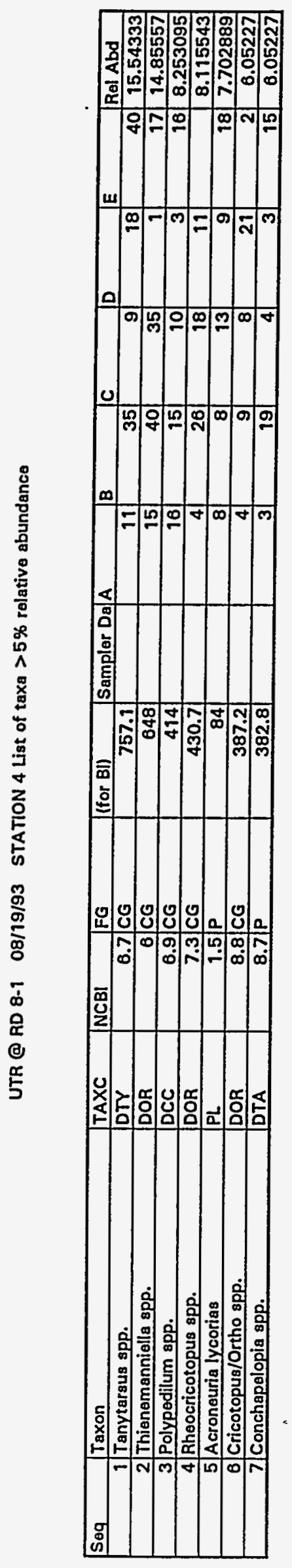




\begin{tabular}{|c|c|c|c|c|c|c|c|c|c|}
\hline Sog & Texon & TAXC & NCBS & FG & $(f \circ x)$ & Sompler Da & A & $B$ & C \\
\hline 1 & Hydrocerho & AHC & 5.7 & $P$ & 28.5 & & 2 & 2 & 1 \\
\hline 2 & Gennmerides & AMG & 6.9 & CG & 0 & & & & \\
\hline 3 & Oripochents & ANO & 8.2 & CG & 18.4 & & & & \\
\hline 4 & Ancronyx veriggatus & $\mathrm{Co}$ & 6.9 & CG & 20.7 & & & & 2 \\
\hline 5 & Dinoutus ep. & Co & 5.5 & $P$ & of & & & & $\rightarrow$ \\
\hline 6 & Eetoppla nervoes & co & 4.3 & Sc & 17.2 & & & & 2 \\
\hline 7 & Goniaimis diatrich & co & 4 & CG & of & & & & \\
\hline B & Mscronychus qlabesture & co & 4.7 & CG & 84.8 & & 2 & 9 & 7 \\
\hline 9 & Mlorocylloopus pusille & Co & 2.1 & CG & 의 & & & & \\
\hline 10 & Optiosorver ap. & co & 2.7 & CG & 요 & & & & \\
\hline 11 & Stanoimin decorale & co & 5.4 & CG & of & & & & \\
\hline 12 & Stonoimic sinuats & co & 5.4 & CG & of & & & & \\
\hline 13 & Stonoimis epp. & co & 5.4 & CG & of & & & & \\
\hline 14 & Comberdes & DCA & 7.2 & PH & of & & & & \\
\hline 15 & Peleomonster paludoeves: & DCA & 6.7 & CG & 6.7 & & & & \\
\hline 16 & Cryplochironomue epp. & DCC & 6.7 & $P$ & 6.7 & & & & \\
\hline 17 & Diarotondipen noomadestus & DDCC & 8.3 & CG & 24.9 & & & & \\
\hline 18. & Dicrotandipee epp. & DOCC & 7.9 & $\mathrm{CG}$ & of & & & & \\
\hline 19 & Leuterborniakio ap. & DCC & (6) & CG & 18 & & & & \\
\hline 20 & Mikrotondipes rydalonsis & DCC & 6.2 & CG & 8.2 & & & & 1 \\
\hline 21 & Microtondipesesp. & DCC & 0.2 & CG & 12.4 & & & & 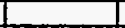 \\
\hline 22 & Nibothouma bobivi & DCC & 5.5 & CG & 5.5 & & & & I) \\
\hline 23 & Proonopeoctro flavipes & DDCC & 8.5 & CG & of & & & & \\
\hline 24 & Polypedium follox & DCC & 6.7 & SHA & 13.4 & & & & 1 \\
\hline 25 & Polypoditum eps. & DCC & 6.9 & Co & 1642.2 & & 2 & 55 & 108 \\
\hline 26 & Stolochiomyia perpulchrs & JDCC & 4.6 & ISH & 23 & & & & 5 \\
\hline 27 & Stenoctir onomus sp. & locc & 6.4 & $\mathbf{S H}$ & of & & & & \\
\hline 29 & Tribolos fuectionrne & DCC & 8 & CG & 18) & & & & \\
\hline 29 & Tribolos haundum & DCC & 6.6 & CG & 의 & & & & \\
\hline 30 & Diemesind genue $P$ & 100 & 7.4 & CG & o) & & & & \\
\hline 31 & Potthestia longmens & JDD & 7.4 & CG & of & & & & \\
\hline 32 & Atheribx lanthes & DO & 2.1 & $\mathbf{P}$ & of & & & & \\
\hline 33 & Ceratopogonid eo & DO & 6.5 & P & of & & & & \\
\hline 34 & Chalifere epp. & Do & 8.1 & CG & of & & & & \\
\hline 35 & Homerodromia spo. & Do & 8.7 & CG & 48.6 & & 1 & 1 & 2 \\
\hline 38 & Simu fam epp. & DO & 4.4 & CF & 4.4 & & $\ldots$ & 1 & 1 \\
\hline 37 & Brila fiarifione & DOA & 5.2 & SH & of & & & & \\
\hline 39 & Corynoneura spp. & DOA & 0.2 & CG & 204.6 & & 21 & 5) & 19 \\
\hline 39 & Cricotopuelortho spg. & DOR & 8.8 & CG & 44) & & 4 & 1) & 3. \\
\hline 10 & Eukialforials sop. & DOA & 5.7 & CG & of & & 7 & & \\
\hline 41) & Nonocladius epp. & DOR & 7.2 & cG & 7.2 & & 1 & & \\
\hline 42 & Orthociodius Egnicola & DOA & 5.4 & SH & 으 & & & & \\
\hline 43 & Perskblafferiallo ep.1 & DOA & 5.9 & CG & 11.8 & & & & \\
\hline 44 & Perakiafforials ep.2 & DOA & 5.9 & CG & of & & & & \\
\hline 45 & Poramotrinconemuse co. & DOR & 3.7 & CG & 22.2 & & 1 & & 4) \\
\hline 46 & Peoctrocladius sp. & DOA & 3.8 & CG & of & & & & \\
\hline 47. & Rhoocriontopure spe. & DOA & 7.3 & CG & 138.7 & & 1 & 3 & 11) \\
\hline 48. & Synorthociodius eomivirans & DOA & 4.7 & CG & 23.5 & & & 3 & 1 \\
\hline 49 & Thionomenniolls spp. & DOR & 8) & CG & 648 & & 24 & 20 & 43 \\
\hline 50 & Ivotaris spp. & DOA & 1 & CG & 16 & & & 2 & \\
\hline 51 & Uniols multivirga & DOA & of & CG & 인 & & & & \\
\hline 52 & Xylopus par & DOR & 8.6 & $\mathrm{SH}$ & 0 & & ? & & - \\
\hline 53 & Abloboemyia spp. & DTA & 6.4 & $P$ & 44.8 & & 1) & & 1 \\
\hline 54 & Crinotonypus pinguis & IDTA & 9.1 & P & of & & & & \\
\hline 55 & Conchspotopia spp. & DTA & 8.7 & $\mathbf{P}$ & 34.8 & & & i) & 3) \\
\hline 50 & Labrundinia spg. & DTA & 6) & $\bar{P}$ & a & & & & $T$ \\
\hline 57 & Natereis sp.A & DTA & 10 & $\mathbf{P}$ & o & & & . & a \\
\hline 58 & Niblonypuse spp. & DTA & 4 & $\mathbf{P}$ & 12) & & & 1 & 1 \\
\hline 59 & Peramering sp. & DTA & 2.8 & $\mathbf{P}$ & of & & & & \\
\hline 60 & Pontaneura inconspiaus & DTA & 4.6 & $\mathbf{P}$ & a) & & & & \\
\hline 81 & Piheotentereue cop. & DTY & 6.4) & CF & 492.8 & & 2 & 43) & 11) \\
\hline 62 & Stompoling spg. & DrY & 2 & CG & o) & & & & \\
\hline 63 & Tenyter mue spp. & IDTY & 6.7 & CG & 1025.1 & & 4) & 1 & 45 \\
\hline 64) & Acerponse pyomerue & EP & 3.7 & CG & 29.6 & & 2 & (3) & 3 \\
\hline 65 & Bootie spg. & EPP & 5.4 & CG & 75.61 & & & 3 & 4 \\
\hline 66 & Coonis epp. & EP & 7.8 & CG & of & & & & \\
\hline 67 & Eurylopholla app. & EP & 3 & CG & 18 & & & & 6) \\
\hline 88 & Heptogenia spp. & EP & 2.8 & Sc & 0 & & & & \\
\hline 69 & isonychia sp. & EP & 3.8 & $C$ & 7.6. & & & & 2 \\
\hline 70 & Nooephamera youngi & EP & 2.11 & CG & of & & & & $\square$ \\
\hline 71 & Parabptophlabia spg. & EP & 1.2 & CG & of & & & & \\
\hline 72 & Stenonams epp. & EP & 3.41 & sc & 285.6 & & 11) & 14 & 29 \\
\hline 73 & Tricorythodes spp. & EP & 5.4 & CG & 54. & & & & 7 \\
\hline 74 & Sphoerium spp. & $\mathrm{MB}$ & 7.7 & CF & 15.4 & & & & \\
\hline 75 & Corydahis cormutus & ME & 5.8 & $P$ & 61.8 & & 2 & 2 & 3) \\
\hline 78 & Nipronia merricornis & ME & 5.5 & $\mathbf{P}$ & of & & & & \\
\hline 77 & Sistis spp. & ME & 7.5 & $\mathbf{P}$ & of & & & & \\
\hline 78 & Forriosia sp. & MG & 6.9 & Sc & of & & & & \\
\hline 79 & Physella spp. & MG & 9.1 & se & 9.1 & & & & \\
\hline Bo: & \begin{tabular}{|l} 
Viviperides \\
\end{tabular} & MG & 6.7 & Sc & 8.7 & & & & \\
\hline B1 & Boyerla vinoso & 100 & 6.3 & $\mathbf{P}$ & of & & & & \\
\hline 82) & Coonsopionid oo & 100 & 9 & $P$ & of & & & & \\
\hline 83 & Gomphue spp. & 00 & 6.2) & 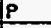 & 6.2 & & & & \\
\hline 84 & Acronouxis abnormil & PL & 2.2 & $P$ & of & & & & \\
\hline 85 & Acronouria ronose & $P L$ & 2.2 & $\mathbf{P}$ & of & & & & \\
\hline 86 & Acronouria mola & $\mathbf{P L}$ & 0.9 & $\mathrm{P}$ & of & & & & \\
\hline 87. & Acronouxia_epp. & $P L$ & 1.4 & $P$ & of & & & & \\
\hline B8] & Annoting spp. & PLL & ol & P & of & & & & \\
\hline
\end{tabular}


TINKER CR. O KENNEDY PONO RD O8/19/93 STATTION 5

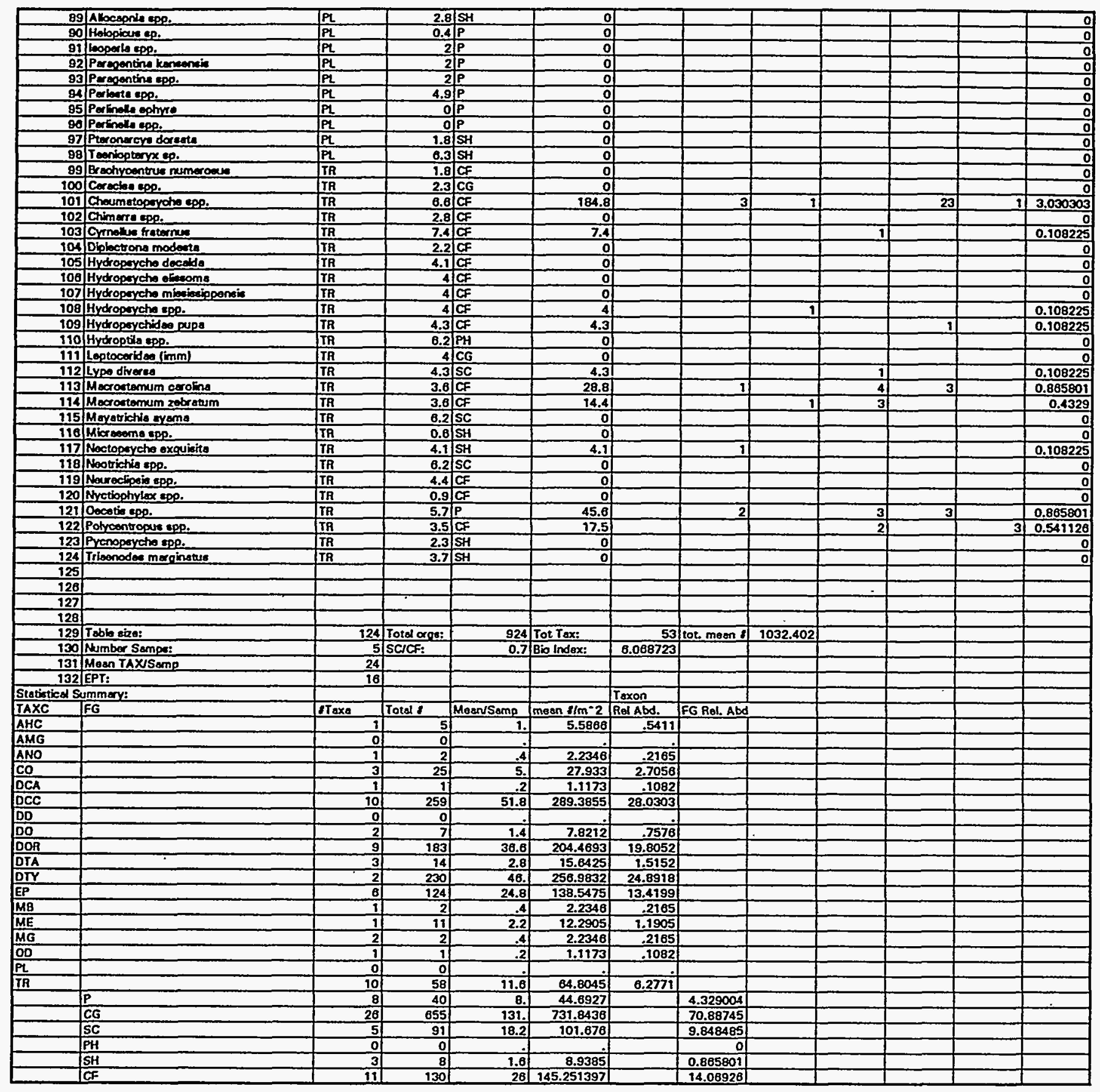




\section{TINKER CR. @ KENNEDY POND RD 08/19/93 STÁTION 5}

\begin{tabular}{|l|}
\hline Taxa List: \\
\hline Hydracarina \\
\hline Oligochaeta \\
\hline Ancyronyx variegatus \\
\hline Ectopria nervosa \\
\hline Macronychus glabratus \\
\hline Palaemonetes paludosus \\
\hline Cryptochironomus spp. \\
\hline Dicrotendipes neomodestus \\
\hline Lauterborniella sp. \\
\hline Microtendipes rydalensis \\
\hline Microtendipes spp. \\
\hline Nilothauma babiyi \\
\hline Polypedilum fallax \\
\hline Polypedilum spp. \\
\hline Stelechomyia perpulchra \\
\hline Tribelos fuscicorne \\
\hline Hemerodromia spp. \\
\hline Simulium spp. \\
\hline Corynoneura spp. \\
\hline Cricotopus/Ortho spp. \\
\hline Nanocladius spp. \\
\hline Parakiefferiella sp.1 \\
\hline Parametriocnemus sp. \\
\hline Rheocricotopus spp. \\
\hline Synorthocladius semivirens \\
\hline Thienemanniella spp. \\
\hline Tvetenia spp. \\
\hline Ablabesmyia spp. \\
\hline Conchapelopia spp. \\
\hline Nilotanypus spp. \\
\hline Rheotanytarsus spp. \\
\hline Tanytarsus spp. \\
\hline Acerpenna pygmaeus \\
\hline Baetis spp. \\
\hline Eurylophella spp. \\
\hline Isonychia sp. \\
\hline Stenonema spp. \\
\hline Tricorythodes spp. \\
\hline Sphaerium spp. \\
\hline Corydalus cornutus \\
\hline Physella spp. \\
\hline Viviparidae \\
\hline Gomphus spp. \\
\hline Cheumatopsyche spp. \\
\hline Cyrnellus fraternus \\
\hline Hydropsyche spp. \\
\hline Hydropsychidae pupa \\
\hline Lype diversa \\
\hline
\end{tabular}


TINKER CR. @ KENNEDY POND RD 08/19/93 STATION 5

Macrostemum carolina

Macrostemum zebratum

Nectopsyche exquisita

Oecetis spp.

Polycentropus spp. 


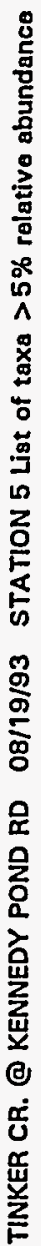

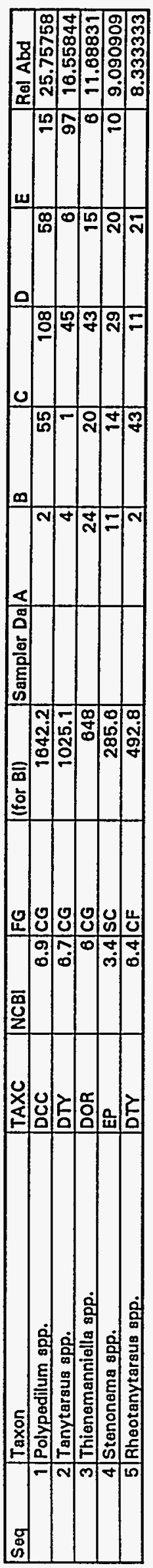




\begin{tabular}{|c|c|c|c|c|c|c|c|c|c|}
\hline $\operatorname{seg}$ & Texon & TAXC & NCB & FG & (for 8 ) & Sempler Da & A & $\mathrm{B}$ & C \\
\hline 1 & Hydrecerine & AHC & 5.7 & $\mathbf{p}$ & 57 & & 4 & 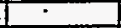 & 5 \\
\hline 2 & Gemmeriden & AMG & 6.9 & CG & 의 & & 1 & 1 & \\
\hline 3 & Otiogcheots & ANO & 8.2 & CG & 0 & & & & \\
\hline 1 & Anoyronyx verisogatase & $\mathrm{CO}$ & 6.9 & CG & 13.8 & & & & \\
\hline 5 & Oirmutuesp. & $\mathrm{CO}$ & 5.5 & $p$ & of & & & & \\
\hline 6 & Eetopria norvosa & Co & 4.3 & SC & of & & & & \\
\hline 7 & Gonishmis diartach & Co & 4 & CG & of & & & & \\
\hline $\boldsymbol{\theta}$ & Mecromychese olabratus & Co & 4.7 & CG & 244.4 & & 13 & 10 & 4 \\
\hline 9 & 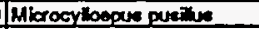 & $\mathrm{co}$ & 2.1 & CG & 2.1 & & & & \\
\hline 10 & Optoperveses. & Co & 2.7 & CG & of & & & & \\
\hline 11 & Standinis crenater & co & 5.4 & CG & 750.6 & & 62 & 18 & 15 \\
\hline 12 & Stansimis decorate & Co & 5.4 & CG & of & & & & \\
\hline 13 & Stencimis einuets & $\mathrm{Co}$ & 5.4 & CG & 의 & & & & \\
\hline 14 & Stencimis spp. & $\overline{C O}$ & 5.4 & CG & of & & & & \\
\hline 15 & Camberides & DOCA & 7.2 & PH & o & & & & \\
\hline 10 & Cryptochironomus epp. & DCC & 6.7 & P & 13.4 & & & & 1 \\
\hline 17 & Olarotandipes epp. & DCC & 7.9 & $\overline{\mathbf{C G}}$ & of & & & & \\
\hline 18 & Mlorotendipes ordetoncis & DCG & 6.2 & CG & of & & & & \\
\hline 19 & Microtondipen epp. & DCC & 6.2 & CG & of & & & & \\
\hline 20 & Notheuma bebiyi & DCCC & 5.5 & CG & 49.5 & & & 4 & 5) \\
\hline 21. & Phoonopeoctre flavipoes & DCC & 8.5 & CG & of & & & & $\rightarrow$ \\
\hline 22 & Potypodium faxtex & DCC & 6.7 & SH & 20.1 & & 2 & & \\
\hline 23 & Pohypoditum epp. & Docc & 6.9 & CG & 331.2 & & 9 & 9 & 10 \\
\hline 24 & Istoloctiomyia perpuichra & JDCC & 4.6 & SH & 41.4 & & 4) & 2 & 2 \\
\hline 25 & Stenoctironomus ep. & DDCC & 0.4 & SHH & 8.4 & & & & \\
\hline 28 & IIrizolos joundum & DCC & 6.0 & CG & of & & & & \\
\hline 27 & Dismesini genue $P$ & DD & 7.4 & CG & of & & & & \\
\hline 28 & Potthentie fongmens & DO & 7.4 & CG & 0 & & & & \\
\hline 29 & A therix lanthe & DO & 2.1 & $P$ & 2.1 & & & & \\
\hline 30 & Coratopoponideo & DO & 6.5 & $P$ & of & & & & \\
\hline 31 & Cholffera epp. & Do & 8.1 & CG & a & & & & \\
\hline 32 & Hemerodromin spp. & 100 & 8.1 & CG & 315.9 & & 13 & 8 & 8 \\
\hline 33 & Polpomyia cpp. & DO & 6.9 & $\vec{P}$ & 6.9 & & & & 1 \\
\hline 34 & Simuleum cpp. & 100 & 4.4 & CF & 30.8 & & 3 & & 1 \\
\hline 35 & Brille floviffon & DOA & 5.2 & SH & 5.2 & & 1 & & at \\
\hline 36 & Corynoneura spp. & DOR & 6.2 & CG & 155 & & 4 & a & 11 \\
\hline 37 & Cricotopulartho spp. & DOA & 8.8 & CG & 211.2 & & 4 & 2 & .7 \\
\hline 38 & Eukbifferiolls spg. & DOR & 5.7 & CG & of & & & & \\
\hline 39 & Lopecelodius epp. & DOA & 2.2 & $\overline{\mathbf{C G}}$ & 2.2 & & 4 & & 1 \\
\hline 40 & Nanociod ius spp. & DOR & 7.2 & CG & 57.6 & & 1 & 1 & 2 \\
\hline 41 & Orthoctodice Fonicols & DOR & 5.4 & SH & of & & $\pi$ & T & $\overline{7}$ \\
\hline 42 & Perakbalferialla sp.1 & DOR & 5.9 & CG & 19.8 & & & & 1 \\
\hline 43 & Perametribenemus ip. & DOR & 3.7 & CG & 229.4 & & 16 & 8 & 15 \\
\hline 44 & Peoctroclodiue ep. & DOR & 3.8 & CG & 0 & & & & \\
\hline 45 & Rheocriootopue tpp. & DOR & 7.3 & CG & 1043.9 & & 21 & 11 & 58 \\
\hline 40 & Synorthocledive cernivirans & DOR & 4.7 & CG & 4.7 & & & 1 & \\
\hline 47 & Thianemanniollo epp. & DOR & (8) & $\mathbf{C G}$ & 1230 & & 32 & 34 & 95 \\
\hline 48 & Tratenila epp. & DOR & 4 & CG & 16 & & 1 & 1 & 1 \\
\hline 49 & Uniolla meltivinga & DOR & of & CG & 0 & & & & \\
\hline 50 & Xylopeisper & DOR & 6.6 & SH & of & & & & \\
\hline 51 & Pecudochínonomue spp. & DPC & 4.2 & CG & 4.2 & & & & \\
\hline 52 & Ablaboomyia epp. & DTA & 8.4 & $\mathbf{P}$ & 8.4 & & & & II \\
\hline 53 & Cinotanypus pinquis & OTA & 9.1 & $\mathbf{P}$ & of & & & & \\
\hline 54 & Conchropolopio spp. & OTA & 8.7 & $\mathbf{P}$ & 374.1 & & 141 & 8 & 15 \\
\hline 55 & Labrundinia epp. & DTA & 6 & $\mathbf{P}$ & of & & & & \\
\hline 56 & Notereia ep. A & DTA & 10 & $P$ & of & & & & \\
\hline 57 & Ninotenypurs spg. & DTA & 4 & $\mathbf{P}$ & of & & & & \\
\hline 58 & Paremerina sp. & DTA & 2.8 & $\mathbf{P}$ & 0 & & & & \\
\hline 59 & Pontanoura inconspioua & DTA & 4.6 & $\bar{P}$ & 23 & & & & 5 \\
\hline 60 & Fhootonytarase spp. & DTY & 6.4 & CF & 256 & & 8 & 15 & 11 \\
\hline a1 & Stompolina epp. & DTY & 2 & CG & 4 & & 11 & if & \\
\hline 62 & Tanytereus spp. & DTY & 8.7 & CG & 415.4 & & 17 & 12 & 22 \\
\hline 63 & Acorpans pyomoous & EP & 3.7 & CG & 0 & & & & + \\
\hline 64 & Bootie spp. & EP & 5.4 & CG & 91.8 & & 4 & 1) & 1 \\
\hline 65 & Coonie rop. & EP & 7.6 & CG & of & & & & \\
\hline 68 & Euryboholla spp. & EP & 3 & CG & 0 & & & & \\
\hline 67 & Hepteoenio spe. & EP & 2.8 & SC & 0 & & 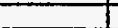 & & \\
\hline 68 & Nooophemera yound & EP & 2.1 & CG & 8.4 & & 1 & 1 & 1 \\
\hline 89 & Proloptophlabia epp. & $E P$ & 1.2 & CG & 0 & & & & \\
\hline 70 & Stenonems epp. & EP & 3.4 & SC & 30.6 & & 4 & 1) & 3) \\
\hline 711 & Tricorythodes epp. & EP & 5.4 & CG & 0 & & T & & \\
\hline 72 & Corydatus cornoutus & ME & 5.6 & $P$ & 5.6 & & 1 & & \\
\hline 73 & Nioronia certicornis & ME & 5.5 & $\mathbf{P}$ & 0 & & & & \\
\hline 74 & Sialie app. & ME & 7.5 & $\mathbf{P}$ & a & & & & \\
\hline 75 & Ferrisesio sp. & MG & 6.9 & SC & o & & & & \\
\hline 78 & Boyeris vinosa & $O D$ & 8.3 & $P$ & of & & & & \\
\hline 77 & Cooneorionid os & 100 & g) & $P$ & o. & & & & \\
\hline 78 & Acronouris abnormic & $\overline{P L}$ & 2.21 & $\mathbf{P}$ & 44 & & 7 & II & (3) \\
\hline 79 & Acroneerria wenosa & $\mathbf{P L}$ & 2.2 & $\mathbf{P}$ & 0 & & & & \\
\hline 60 & Acronecurie mola & PL & 0.9 & $\mathbf{P}$ & of & & & & \\
\hline 81 & Acronourio spp. & $P L$ & 1.4 & $\mathbf{P}$ & of & & & & \\
\hline 82 & Agnotina epp. & $P L$ & of & $\overline{\mathbf{P}}$ & 0 & & & & \\
\hline 83 & Allocapnis ipp. & $P L$ & 2.8 & SH & 8.4 & & 2 & & t \\
\hline 84 & Helopious ep. & $\overline{P L}$ & 0.41 & $\bar{P}$ & 0 & & & & \\
\hline 85 & looporla spp. & PL & 2 & $\mathbf{P}$ & 0 & & & & \\
\hline 86 & Perogentina immerginate & PL. & 1.7 & $\mathbf{P}$ & 15.3 & & 4 & 1 & 1 \\
\hline 87 & Perogentina kansendis & $P L$ & 21 & $\mathbf{P}$ & 0 & & & & \\
\hline 88 & Perspenting spp. & PL & 21 & $\mathbf{P}$ & of & & & & \\
\hline
\end{tabular}




\begin{tabular}{|c|c|c|c|c|c|c|c|c|c|c|c|c|}
\hline 69: & Perionte epp. & $P L$ & 4.9 & $p$ & 0 & ] & & & & & & 의 \\
\hline 80 & Perlinele ephyo & $\mathbf{P L}$ & 은 & P & 0 & & & & & & & 0 \\
\hline 91 & Perlinolle Epg. & $\mathbf{P L}$ & $\mathbf{0}$ & $P$ & 0 & & & & & & & 0 \\
\hline 92 & Pteronwere doreate & $P L$ & 1.8 & SH & 5.4 & & 1 & & & i) & 1 & 0.291202 \\
\hline 83 & Teariopteryx ip. & $\mathbf{P L}$ & 6.3 & ISH & of & & & & & & & 0 \\
\hline 94 & Anicocentropes pre cloides & TR & 0.8 & SH & 2.4 & & 1 & & 1 & & 1 & 0.291282 \\
\hline 95 & Brechyoentrus numeromes & Th & 1.8 & CF & 0 & & & & & & 7 & 0 \\
\hline 90 & Cerecten epp. & TR & 2.3 & CG & 0 & f) & & & & & & 0 \\
\hline 97 & Choumstopencthe epp. & TR & 6.6 & CF & 20.4 & & 1 & & 3 & & & 0.38835 \\
\hline 88 & Chinerre epp. & $T R$ & 2.8 & $C F$ & 0 & & & & & & & 여 \\
\hline 99 & Cyrnalue fratornere & $T A$ & 7.4 & CF & 0 & & & & & & & o) \\
\hline 100 & Diplactione modenta & TR & 2.2 & $\overline{C F}$ & 0 & & & & & & & 0 \\
\hline 101 & Hydroperych decedds & TR & 4.1 & CF & 0 & & & & & & & 0 \\
\hline 102 & Hydroperyche oripoms & rs & 4 & $C F$ & 0 & & & & & & & o \\
\hline 103 & Hydropeycho mineipipgonein & In & 4 & CF & 의 & & & & & & & 0 \\
\hline 104 & Hydroperyche epp. & IR & 4 & CF & 0 & & & & & & & 0 \\
\hline 105 & Hyckoptile epp. & TR & 8.2 & $P \mathbf{P H}$ & 아 & & & & & & & 의 \\
\hline 100 & Lepidostome sp. & $T A$ & 1 & SH & 1 & & & & & & 1 & 0.097087 \\
\hline 107 & Leptocerideo (inm) & TR & 4 & CG & of & & & & & & & 은 \\
\hline 108 & Lype diverees & TR & 4.3 & SC & of & & & & & & & 0 \\
\hline 109 & Moyatrichle oyams & TA & 6.2 & SC & o & & & & & & & 의 \\
\hline 110 & Miloresomesep. & TR & 0.6 & $\mathrm{SH}$ & 의 & & & & & & & 0 \\
\hline 111 & Noctopaycho epp. & TR & 4.1 & SH & of & & & & & & & 의 \\
\hline 112 & Neotrichia epp. & TR & 6.2 & Sc & of & & & & & & & 의 \\
\hline 113 & Narroclipeie epp. & Ta & 4.4 & CF & o & & & & & & & 0 \\
\hline 114 & Nyetbophylox $<p$. & TA & 0.9 & $C$ & of & 1 & & & & & & 0 \\
\hline 115 & Oocotis rpp. & TR & 5.7 & P & 5.7 & & & & 1 & & & 0.097087 \\
\hline 116 & Pohycantopute cpp. & In & 3.5 & CF & of & & & & & & & 0 \\
\hline 117 & Peitotrata ap. & IA & of & SC & of & & & & 1 & & & 0.097087 \\
\hline 110 & Pycnoperyche spp. & TA & 2.3 & SH & of & & & & & & & 0 \\
\hline 119 & & & & & & & & & & & & \\
\hline 120 & & & & & & & & & & & & \\
\hline 121 & & & & & & & & & & & & \\
\hline 122 & & & & & & & & & & & & \\
\hline 123 & Table size: & 118 & Totel org: & 1030 & Tot Tex: & 48 & tot. moon of & 1150.838 & & & & \\
\hline 124 & Number Sompe: & 5 & SCICF: & 0.19807843 & Bio Index: & 6.00088 & & & & & & \\
\hline 125 & Mean TAX Semp & 27.2 & & & & & & & & & & \\
\hline 128 & EPT: & 12 & & & & & & & & & & \\
\hline Statisticel Su & ummery: & & & & & Taxon & & & & & & \\
\hline TAXC & FG & Taxa & Totel ? & Moan/Samp & $\operatorname{magn} 1 / m^{*} 2$ & Rel Abd. & FG Rol. ABd & & & & & \\
\hline AHC & & 1 & 10 & 2. & 11.1732 & .9709 & & & & & & \\
\hline AMG & & of & of & & .9 & & & & & & & \\
\hline ANO & & of & of & & & & & & & & & \\
\hline CO & & 4 & 194 & 38.8 & 216.7598 & 18.835 & & & & & & \\
\hline $\mathrm{DCA}$ & & of & 0 & & & & & & & & & \\
\hline DCC & & 8) & 72 & 14.4 & 80.4469 & 6.9903 & & & & & & \\
\hline$D D$ & & of & of & & & & & & & & & \\
\hline DO & & 4 & 48 & 9.6 & 53.6313 & 4.6602 & & & & & & \\
\hline DOA & & 11 & 478 & 95.2 & 537.8436 & 46.2136 & & & & & & \\
\hline$D P C$ & & 1 & 11 & .2 & 1.1173 & .0971 & & & & & & \\
\hline DTA & & 3 & 49 & 9.8 & 54.7486 & 4.7573 & & & & & & \\
\hline DTY & & 3| & 104 & 20.8 & 116.2011 & 10.0971 & & & & & & \\
\hline EP & & 3 & 30 & 6. & 33.5198 & 2.9128 & & & & & & \\
\hline ME & & 1 & 1 & .2 & 1.1173 & .0971 & & & & & & \\
\hline MG & & of & of & & & & & & & & & \\
\hline GD & & of & of &. & & & & & & & & \\
\hline$P L$ & & 4 & 35 & 7. & 39.1081 & 3.3989 & & & & & & \\
\hline rR & & 5 & 10 & 2. & 11.1732 & .9709 & & & & & & \\
\hline & $\mathbf{P}$ & 11 & 94 & 18.8 & 105.0279 & & 9.126214 & & & & & \\
\hline & $\mathbf{C G}$ & 22 & 851 & 170.2 & 950.838 & & 82.62136 & & & & & \\
\hline & SC & 2 & 10 & 2. & 11.1732 & & 0.970874 & & & & & \\
\hline & $P H$ & of & of & & & & of & & & & & \\
\hline & SH & e & 24 & 4.8 & 26.8158 & & 2.330097 & & & & & \\
\hline & CF & \begin{tabular}{l|l}
3 \\
\end{tabular} & 51) & 10.2 & 58.9832402 & & 4.951458 & & & & & \\
\hline
\end{tabular}




\section{TINKER CR. @ RD 2-1 08/19/93 STATION 6}

\begin{tabular}{|l|}
\hline Taxa List: \\
\hline Hydracarina \\
\hline Aricyronyx variegatus \\
\hline Macronychus glabratus \\
\hline Microcylloepus pusillus \\
\hline Stenelmis crenatus \\
\hline Cryptochironomus spp. \\
\hline Nilothauma babiyi \\
\hline Polypedilum fallax \\
\hline Polypedilum spp. \\
\hline Stelechomyia perpulchra \\
\hline Stenochironomus sp. \\
\hline Atherix lantha \\
\hline Hemerodromia spp. \\
\hline Palpomyia spp. \\
\hline Simulium spp. \\
\hline Brilla flavifrons \\
\hline Corynoneura spp. \\
\hline Cricotopus/Ortho spp. \\
\hline Lopescladius spp. \\
\hline Nanocladius spp. \\
\hline Parakiefferiella sp.1 \\
\hline Parametriocnemus sp. \\
\hline Rheocricotopus spp. \\
\hline Synorthocladius semivirens \\
\hline Thienemanniella spp. \\
\hline Tvetenia spp. \\
\hline Pseudochironomus spp. \\
\hline Ablabesmyia spp. \\
\hline Conchapelopia spp. \\
\hline Pentaneura inconspicua \\
\hline Rheotanytarsus spp. \\
\hline Stempellina spp. \\
\hline Tanytarsus spp. \\
\hline Baetis spp. \\
\hline Neoephemera youngi \\
\hline Stenonema spp. \\
\hline Corydalus cornutus \\
\hline Acroneuria abnormis \\
\hline Allocapnia spp. \\
\hline Paragentina immarginata \\
\hline Pteronarcys dorsata \\
\hline Anisocentropus pyraloides \\
\hline Cheumatopsyche spp. \\
\hline Lepidostoma sp. \\
\hline Pecetis spp. \\
\hline
\end{tabular}


TINKER CR. @ RD 2-1 08/19/93 STATION 6 List of taxa $>5 \%$ relative ebundance

\begin{tabular}{|c|c|c|c|c|c|c|c|c|c|c|c|}
\hline Seq & Taxon & TAXC & NCB! & FG & (for Bl) & Sampler Da A & $B$ & C & D & $\underline{E}$ & Rel Abd \\
\hline 1 & Thianemanniella spp. & DOR & & $C G$ & 1230 & 32 & 34 & 95) & 27 & 17 & 19.90291 \\
\hline 2 & Rheocricotopus spp. & DOR & 7.3 & $C G$ & 1043.9 & 21 & 11 & 58 & 35 & 18 & 13.8835 \\
\hline 3 & Stenelmis crenstus & $\mathrm{Co}$ & 5.4 & CG & 750.6 & 62 & 18 & 15 & 37 & 9 & 13.49515 \\
\hline 4 & Parametriocnemus sp. & DOR & 3.7 & CG & 229.4 & 16 & 8 & 15 & 10 & 13 & 6.019417 \\
\hline 5 & Tanytarsus spp. & DTY & 6.7 & CG & 415.4 & 17 & 12 & 22 & 6 & 5 & 6.019417 \\
\hline & Macronychus glabratus & Co & 4.71 & CG & 244.4 & 13 & 10 & 4. & $10 \mid$ & 15 & 5.048544 \\
\hline
\end{tabular}




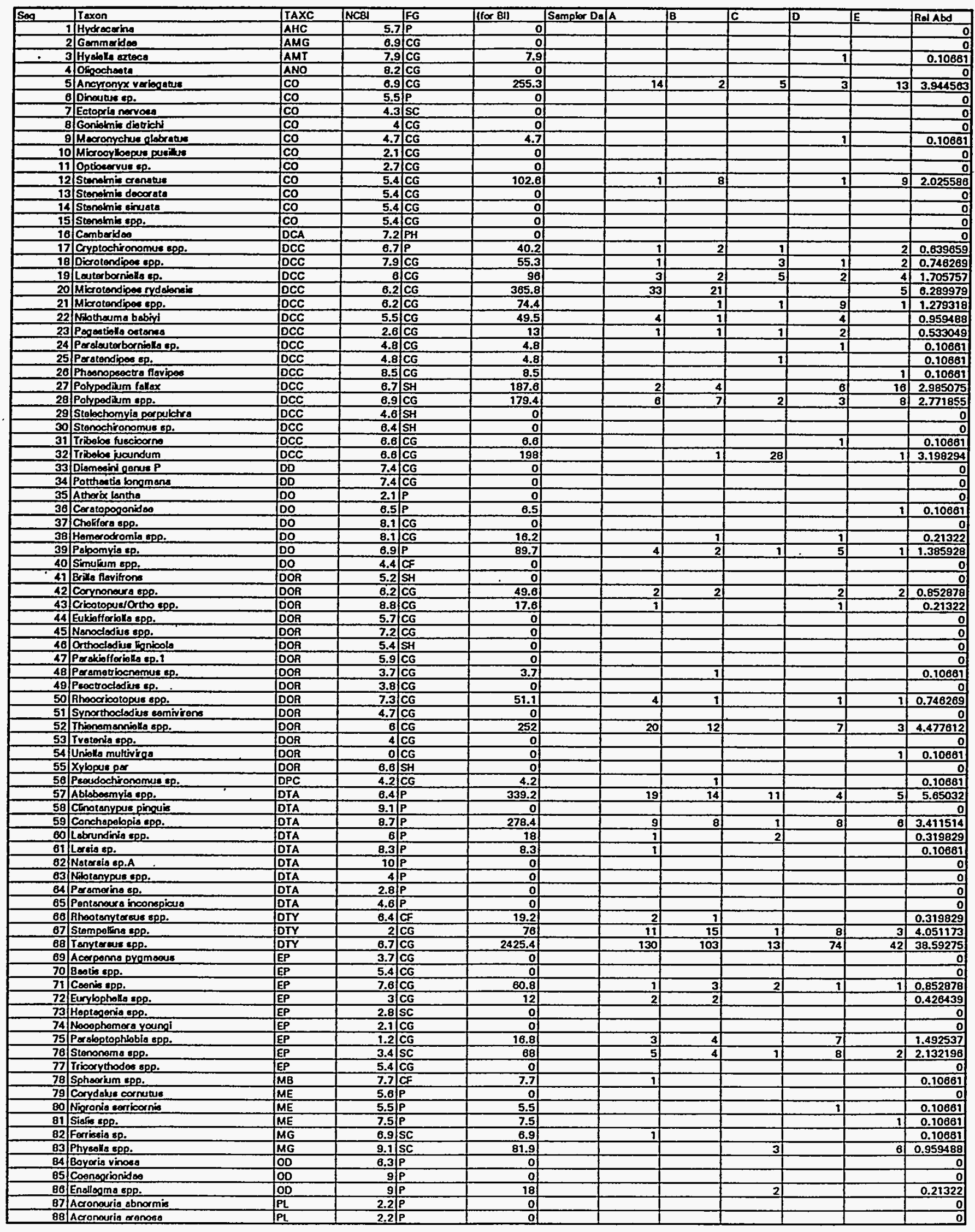




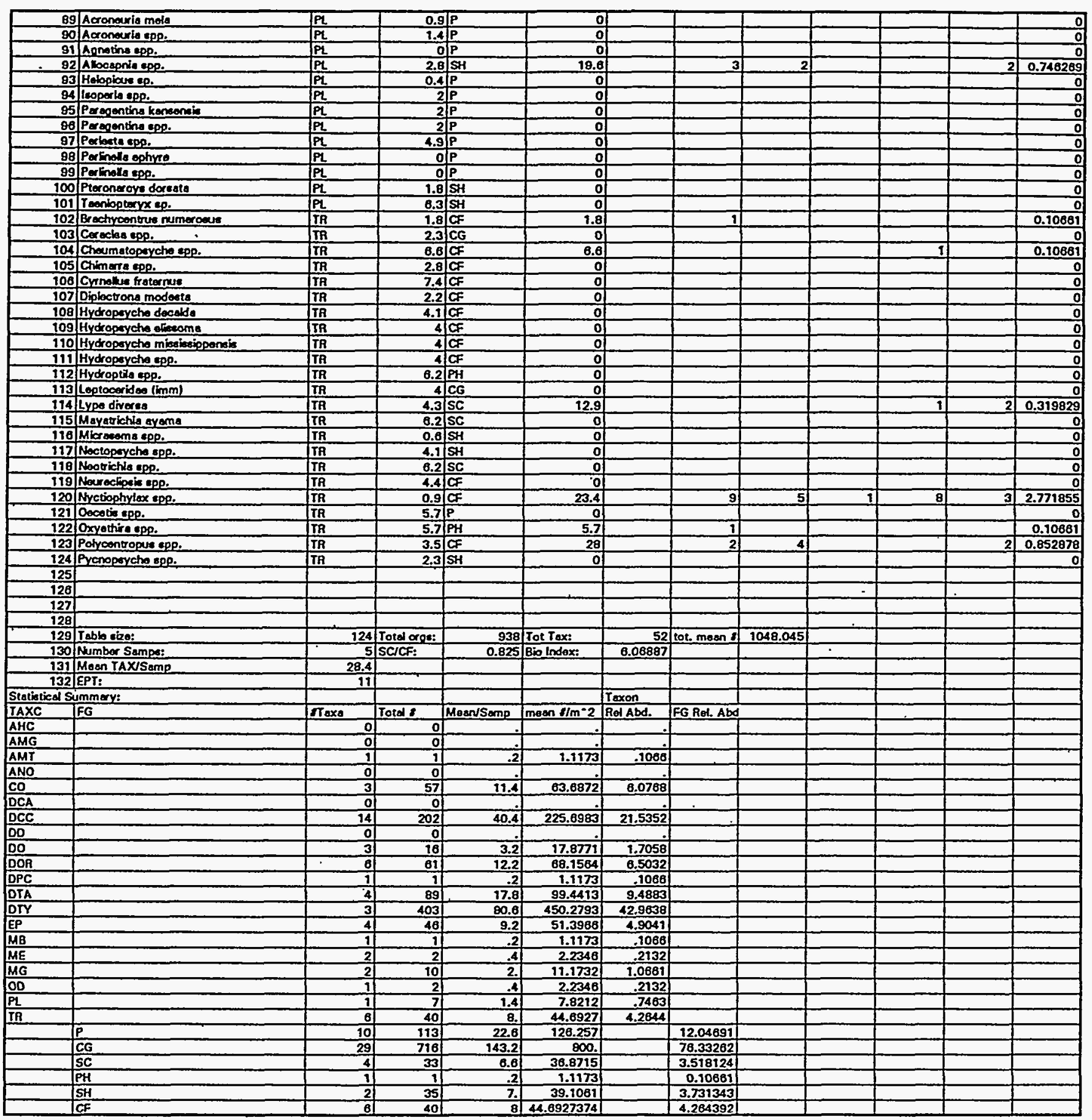


REEDY BR. nr. ATTA SITE 08/19/93 STATION 7

\begin{tabular}{|l|}
\hline Taxa List: \\
\hline Hyalella azteca \\
\hline Ancyronyx variegatus \\
\hline Macronychus glabratus \\
\hline Stenelmis crenatus \\
\hline Cryptochironomus spp. \\
\hline Dicrotendipes spp. \\
\hline Lauterborniella sp. \\
\hline Microtendipes rydalensis \\
\hline Microtendipes spp. \\
\hline Nilothauma babiyi \\
\hline Pagastiella ostansa \\
\hline Paralauterborniella sp. \\
\hline Paratendipes sp. \\
\hline Phaenopsectra flavipes \\
\hline Polypedilum fallax \\
\hline Polypedilum spp. \\
\hline Tribelos fuscicorne \\
\hline Tribelos jucundum \\
\hline Ceratopogonidae \\
\hline Hemerodromia spp. \\
\hline Palpomyia sp. \\
\hline Corynoneura spp. \\
\hline Cricotopus/Ortho spp. \\
\hline Parametriocnemus sp. \\
\hline Rheocricotopus spp. \\
\hline Thienemanniella spp. \\
\hline Uniella multivirga \\
\hline Pseudochironomus sp. \\
\hline Ablabesmyia spp. \\
\hline Conchapelopia spp. \\
\hline Labrundinia spp. \\
\hline Larsia sp. I \\
\hline Rheotanytarsus spp. \\
\hline Stempellina spp. \\
\hline Tanytarsus spp. \\
\hline Caenis spp. \\
\hline Eurylophella spp. \\
\hline Paraleptophlebia spp. \\
\hline Stenonema spp. \\
\hline Sphaerium spp. \\
\hline Nigronia serricornis \\
\hline Sialis spp. \\
\hline Ferrissia sp. \\
\hline Enallagma spp. \\
\hline
\end{tabular}


REEDY BR. nr. ATTA SITE 08/19/93 STATION 7

Lype diversa

Nyctiophylax spp.

Oxyethira spp.

Polycentropus spp. 


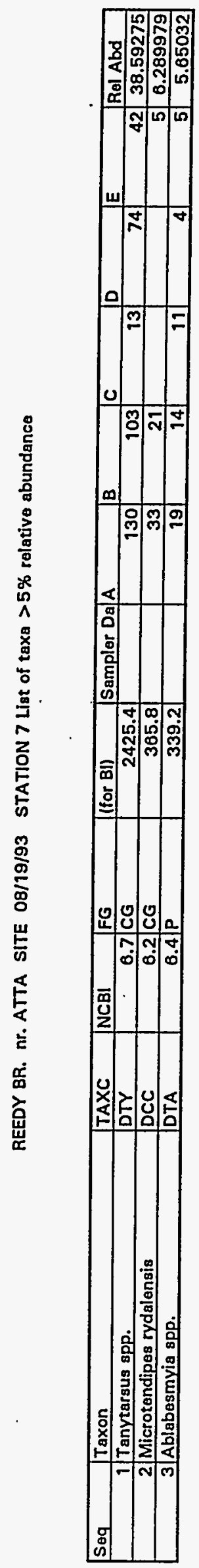




\begin{tabular}{|c|c|c|c|c|c|c|c|c|c|}
\hline Sog & Texan & TAXC & INCBS & FG & (for Bn & Sompler Da & A & 8 & C \\
\hline & Hydrecerine & AHC & 5.7 & $P$ & 0 & & & & \\
\hline 2 & Gommerides & AMG & 6.9 & CG & 6.9 & & & & \\
\hline 3 & Oligacheofe & ANO & 8.2 & CG & 0 & & & & \\
\hline 4 & Anerionyx veriogobes & $\mathrm{co}$ & 0.9 & CG & 69 & & 5 & & 5 \\
\hline 5 & 5 Dineutus ep. & Co & 5.5 & $P$ & 11 & & & 1 & \\
\hline a & Ectopria nervoce & co & 4.3 & SC & 0 & & & & \\
\hline 7 & Gonidmin dietrlahi & co & 4 & CG & 음 & & & & \\
\hline 8 & 3 Mecronveture olebrutus & $\mathrm{Co}$ & 4.7 & CG & 18.8 & & 1 & & 2 \\
\hline 9 & Microcyllospone puritive & Co & 2.1 & CG & 0 & & & & \\
\hline 10 & Optioservive ep. & Co & 2.7 & CG & 의 & & & & \\
\hline 11 & Stensimi crenstur & co & 5.4 & CG & 5.4 & & & & 1 \\
\hline 12 & Standimi decorats & Co & 5.4 & CG & 0 & & & & \\
\hline 13 & Stonolmbe cinuato & co & 5.4 & CG & 의 & & & & \\
\hline 14 & Stengimile spp. & Co & 5.4 & CG & 악 & & & & \\
\hline 15 & Cemberidoo & DCA & 7.2 & PH & of & & & & \\
\hline 10 & Gyptoctionomus epp. & DOCC & 6.7 & $\mathbf{P}$ & 13.4 & & & 3 & \\
\hline 17 & Cryptotondipes so. & DOCC & 6.1 & CG & 67.1 & & 1 & 1 & \\
\hline 18 & Dicrotondipes noomodectus & DCC & 8.3 & CG & 83 & & & 1 & 3) \\
\hline 19 & Dicrolandipes spp. & DCC & 7.9 & CG & 31.6 & & & 1 & 1 \\
\hline 20 & Lauterborniola ep. & DCC & $\theta$ & CG & 6 & & & I) & \\
\hline 21 & Miarotendipos rydelondie & DCC & 6.2 & $\mathrm{CG}$ & 117.8 & & 5 & & 13 \\
\hline 22 & Microlandipes upp. & TDCC & 6.2 & CG & 6.2 & & 1 & & \\
\hline 23 & Nilocheums bebiyi & IDCc & 5.5 & CG & 225.5 & & 14 & 6 & 12 \\
\hline 24 & Paquatiollo ostanse & DOCC & 2.8 & CG & 5.2 & & & & \\
\hline 25 & Persciodopolme epp. & TOCC & 8.4 & CG & 8.4 & & & & 1 \\
\hline 26 & Pordeuterborniolio nipothoter afis & DCC & 4.8 & CG & 19.2 & & & 1 & \\
\hline 27 & Peratandipos ep. & DoCC & 5.3 & CG & 10.0 & & & 2 & \\
\hline 28 & Phoenopeoctra flovipes & DCCC & 8.5 & CG & 17 & & & 1) & \\
\hline 29 & Polypodium follax & DOCC & 6.7 & SH & 46.9 & & 3 & 1 & 2 \\
\hline 30 & Polypadium spe. & DDCC & 6.9 & CG & 1221.3 & & 19 & 3 & 75 \\
\hline 31 & Stolachomyle perpulchra & DCC & 4.6 & $\mathrm{SH}$ & 41.4 & & 2) & 2 & 2 \\
\hline 32 & Stenoctironomus ep. & DCC & 6.4 & SH & of & & & & \\
\hline 33 & Tribelo fuecioorno & DCC & 6 & CG & 342 & & 1 & 29 & 1 \\
\hline 34 & Tribalos lucundum & DCC & 8.6 & CG & 39.8 & & & 6 & \\
\hline 35 & Dlomecini ganus $P$ & DO & 7.4 & CG & of & & & & \\
\hline 36 & Polthostio bongmena & $\mathrm{DD}$ & 7.4 & CG & of & & & & \\
\hline 37 & Atterix lonthe & DO & 2.1 & $P$ & of & & & & $\dot{-}$ \\
\hline 38 & Ceratopononidao & DO & 0.5 & $P$ & 13 & & & & \\
\hline 39 & Cholfera spo. & DO & B.1 & CG & of & & & & \\
\hline 40 & Hemerodromis spp. & Do & 8.1 & CG & 16.2 & & 2 & & \\
\hline A1 & Palpomyia ep. & Doo & 6.9 & $P$ & 213.9 & & 6 & B & 3 \\
\hline 42 & Simulum epp. & 00 & 4.4 & CF & o & & & 7 & \\
\hline 43 & Brillo flevifions & DOR & 5.2 & SF & of & & & & \\
\hline 44 & Corynonours spp. & DOA & 6.2 & CG & 43.4 & & 5 & & 2 \\
\hline 45 & Cricolopul ortho epp. & DOR & 8.8 & CG & 704 & & 32 & & 44 \\
\hline 10 & Eukiafforbiolo epp. & DOA & 5.7 & CG & of & & & & \\
\hline 47 & Nanocladius epp. & DOR & 7.2 & $\overline{C G}$ & 84.8 & & 7 & 1 & It \\
\hline 48 & Qthoolodius Ennicols & DOA & 5.4 & SH & 0 & & & & \\
\hline 49 & Perstuafferiolla ep. I & DOR & 5.9 & CG & 47.2 & & 3 & 4 & \\
\hline 50 & Parmetiocromplas ip. & DOA & 3.7 & CG & 40.7 & & 3 & & 8 \\
\hline 51 & Peactroclodive sp. & DOA & 3.8 & CG & o & & & & \\
\hline 52 & fihoocricotopus spp. & DOA & 7.3 & CG & 452.6 & & 27 & & 34 \\
\hline 53 & Synorthocledive comivitons & DOR & 4.7 & CG & of & & & & \\
\hline 54 & Thionomennialla spp. & DOR & 6) & $\overline{C G}$ & 612 & & 97 & iा & \\
\hline 55 & Tratenis spe. & DOR & 4) & CG & of & & & & 1 \\
\hline 50 & Uniolo multivirge & DOR & 이 & CG & of & & & 1 & 2 \\
\hline 57 & Xyiopere per & DOR & 6.6 & SH & of & & & & T \\
\hline 58 & Abloboemyia epp. & DrA & 6.4 & $\mathbf{P}$ & 678.4 & & 8 & 24 & 3 \\
\hline 59 & Apsectrotanypus ip. & DrA & of & $P$ & of & & & 1 & \\
\hline 60 & Clinotenypu: pinouis & DIA & 9.1 & $\mathbf{P}$ & of & & & & \\
\hline 01 & Conchepolopin opg. & DIA & 8.7 & $\mathbf{P}$ & 600.3 & & 211 & 3. & 35 \\
\hline 62 & Lobrundinio epp. & DTA & 8 & $\mathbf{P}$ & 30 & & & 3 & \\
\hline 63 & Larcin sp. & DIA & 8.3 & $P$ & 16.6 & & & & \\
\hline 64 & Natereia cp. & DTA & 10 & $\mathbf{P}$ & of & & & & \\
\hline 65 & Neotanypus epp. & DIA & 4 & $\mathbf{P}$ & of & & & & \\
\hline 60. & Peramerina cp. & DTA & 2.8 & $\mathbf{P}$ & 5.6 & & & & 2) \\
\hline a7 & Pantonaura inconspious & DTA & 4.6 & $P$ & of & & & & \\
\hline 68 & Proclodiue ep. & DTA & 9.3 & $P$ & 83.7 & & & 1 & \\
\hline 69 & Rhootonyratase spp. & DTY & 6.4 & CF & 569.6 & & 33 & & 52 \\
\hline 70 & Stempoline epe. & DrY & 2 & CG & of & & - & & 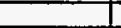 \\
\hline 71 & Stompotinella app. & DTY & 5.3 & CG & 185.5 & & 6 & I & 25 \\
\hline 72 & Tanytareus spp. & DTY & 8.7 & CG & 2659.9 & & 199 & 18 & 143 \\
\hline 73 & Acerpenne pyomsove & EP & 3.7 & CG & of & & & & \\
\hline 74 & Bootis epp. & $E P$ & 5.4 & CG & 10.8 & & 7 & & 7 \\
\hline 75 & Ceanis spp. & EP & 7.6 & CG & 129.2 & & 5) & 3 & 6) \\
\hline 70 & Eurybopholla epp. & $E P$ & 3 & CG & of & & & & \\
\hline 77 & Hoptogonia spp. & EP & 2.8 & SC & of & & & & \\
\hline 78 & Noosephemera youngi & EP & 2.1 & CG & of & & & & \\
\hline 79 & Prodoptophiabla spe. & EP & 1.2 & CG & 2.4 & & 1 & & 1 \\
\hline 80 & Stenonems epp. & $E P$ & 3.4 & SC & 98.6 & & 17 & 2 & 5 \\
\hline 81 & Tricory thoded spp. & EP & 5.4 & CG & 280.8 & & 28 & & 20 \\
\hline 82 & Corydelus cornutus & ME & 5.6 & $P$ & of & & & & \\
\hline 83 & Nigronia cerricornis & ME & 5.5 & $P$ & of & & & & \\
\hline 84 & Sigris epp. & ME & 7.5 & $P$ & ö & & & & \\
\hline 85 & Ferrissia sp. & MG & 8.9 & SC & 0 & & & & \\
\hline 86| & Physolla sp. & MG & 9.1 & SC & 9.1 & & & & 1 \\
\hline 87 & Bororia vinoss & 00 & 6.3 & $P$ & 6.3 & & & & \\
\hline 88) & Coanegrionidoo & $O 0$ & 9 & $P$ & 이 & & & & \\
\hline
\end{tabular}




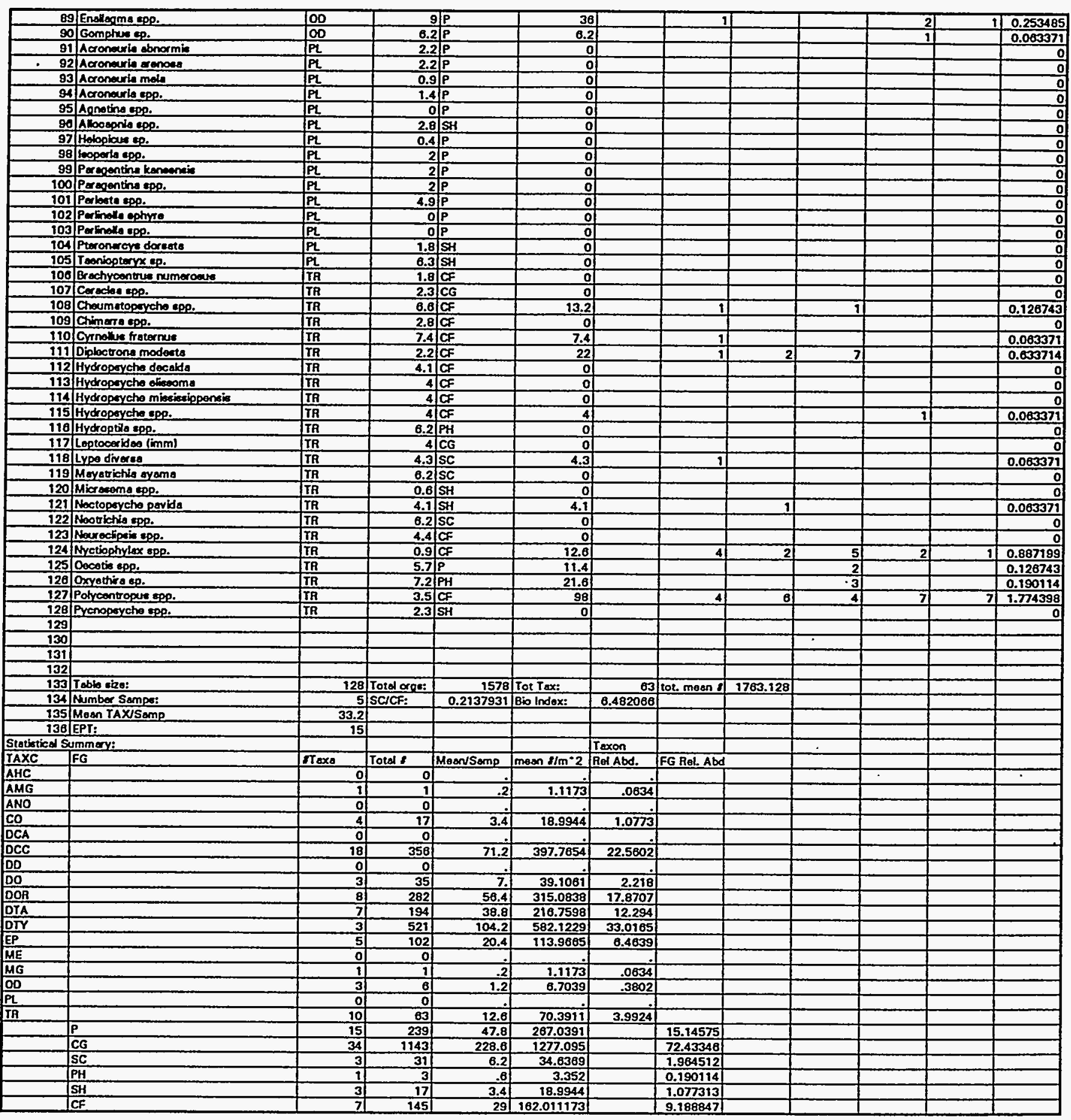


Taxa List:

Gammaridae

Ancyronyx variegatus

Dineutus sp.

Macronychus glabratus

Stenelmis crenatus

Cryptochironomus spp.

Cryptotendipes sp.

Dicrotendipes neomodestus

Dicrotendipes spp.

Lauterborniella sp.

Microtendipes rydalensis

Microtendipes spp.

Nilothauma babiyi

Pagastiella ostansa

Paracladopelma spp.

Paralauterborniella nigrohalteralis

Paratendipes sp.

Phaenopsectra flavipes

Polypedilum fallax

Polypedilum spp.

Stelechomyia perpulchra

Tribelos fuscicorne

Tribelos jucundum

Ceratopogonidae

Hemerodromia spp.

Palpomyia sp.

Corynoneura spp.

Cricotopus/Ortho spp.

Nanocladius spp.

Parakiefferiella sp.1

Parametriocnemus sp.

Rheocricotopus spp.

Thienemanniella spp.

Uniella multivirga

Ablabesmyia spp.

Apsectrotanypus sp.

Conchapelopia spp.

Labrundinia spp.

Larsia sp.

Paramerina sp.

Procladius sp.

Rheotanytarsus spp.

Stempellinella spp.

Tanytarsus spp.

Baetis spp.

Caenis spp.

Paraleptophlebia spp.

Stenonema spp. 
Tricorythodes spp.

Physella sp.

Boyeria vinosa

Enallagma spp.

Gomphus sp.

Cheumatopsyche spp.

Cyrnellus fraternus

Diplectrona modesta

Hydropsyche spp.

Lype diversa

Nectopsyche pavida

Nyctiophylax spp.

Oecetis spp.

Oxyethira sp.

Polycentropus spp. 


\begin{tabular}{|c|c|c|c|c|c|c|c|c|c|c|}
\hline Seg & Taxon & TTAXC & NCBI & (for Bil) & Sampler Da:A & 8 & C & $D$ & $E$ & Rol Abd \\
\hline & \begin{tabular}{l|l}
2 & Polypodilum spp. \\
\end{tabular} & DCC & \begin{tabular}{ll|l}
$\mathrm{CC}$ \\
$.9 \mathrm{C}$
\end{tabular} & 1221.3 & 19 & 3 & 75 & 52 & 28 & \begin{tabular}{l|l|}
8 & 11.21873 \\
\end{tabular} \\
\hline & 3 Ablabosmyis spp. & DTA & 6.4/P & 878.4 & 8 & 24 & 3 & 36 & 35 & \begin{tabular}{|l|l|}
5 & 0.717364 \\
\end{tabular} \\
\hline & 4 Thienemannialla spp. & DOR & $\begin{array}{ll}8 & \mathrm{CC} \\
\end{array}$ & 612 & 97 & 1 & & 3 & & \begin{tabular}{l|l|}
1 & 6.463878 \\
\end{tabular} \\
\hline & \begin{tabular}{l|l|l}
5 Rhootanytarsus spp. \\
\end{tabular} & DTY & $8.4 \mathrm{CF}$ & 569.6 & 33 & & 52 & & & \begin{tabular}{|l|l|}
4 & 5.640051 \\
\end{tabular} \\
\hline
\end{tabular}




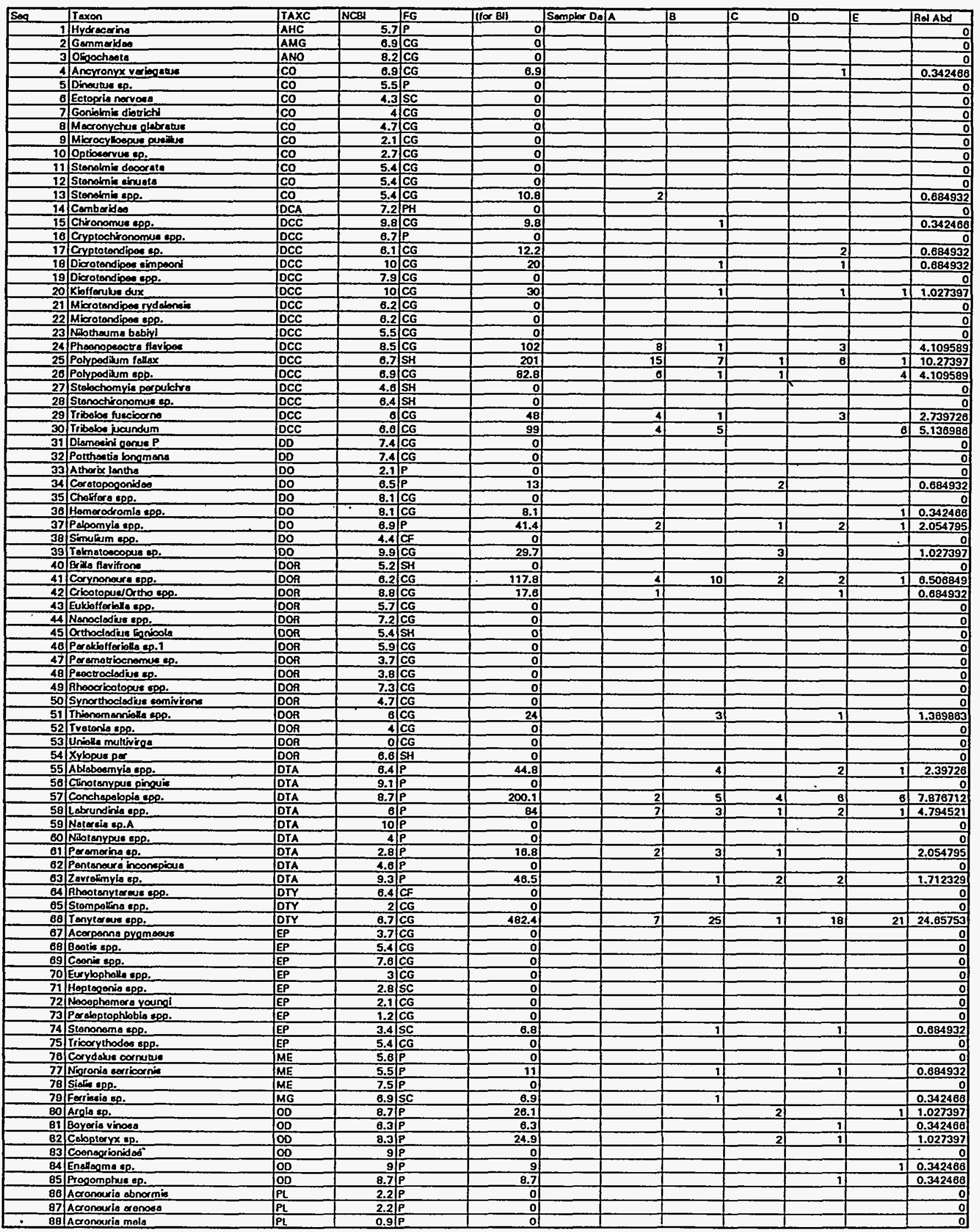




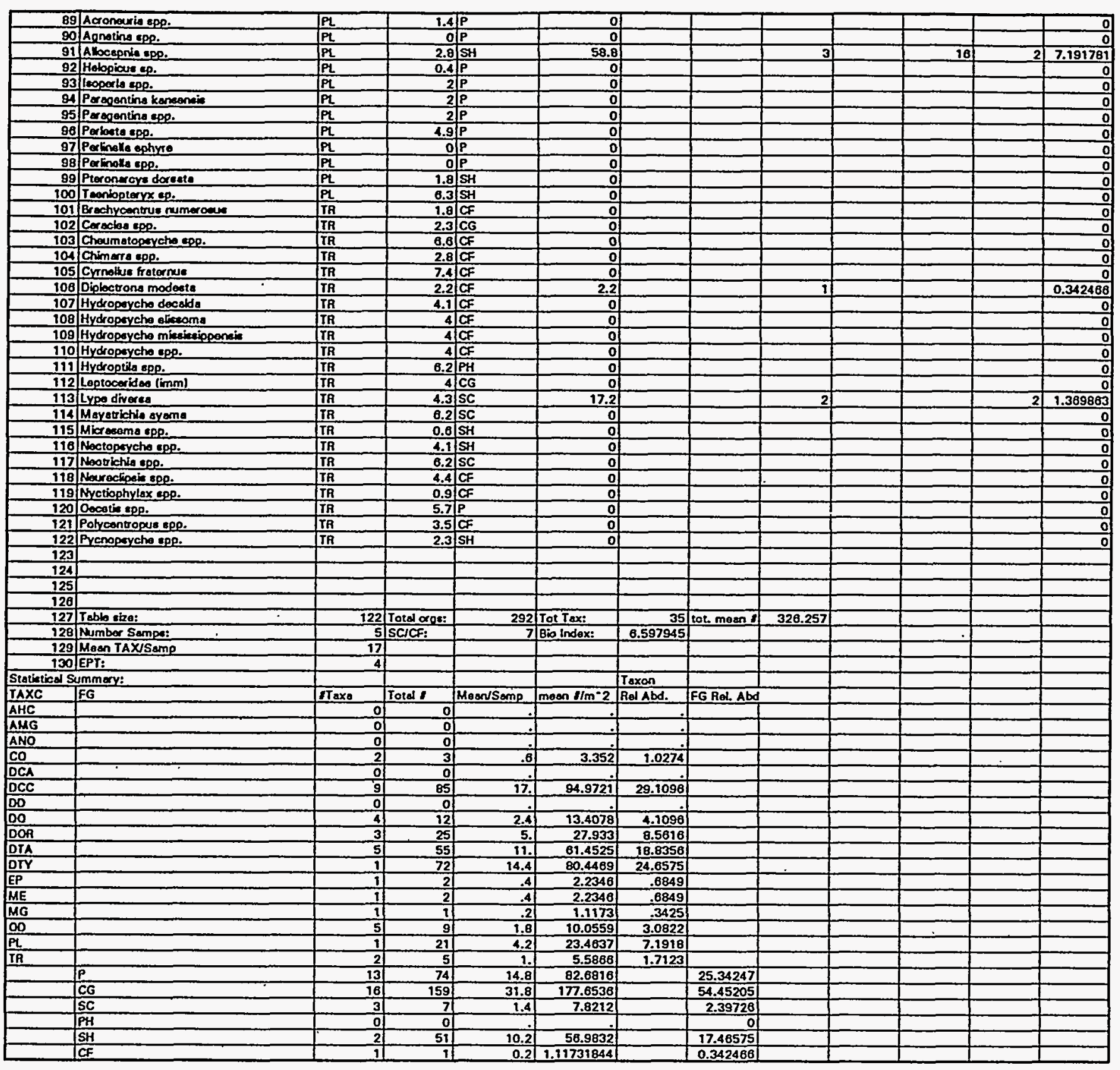




\begin{tabular}{|l|}
\hline Taxa List: \\
\hline Ancyronyx variegatus \\
\hline Stenelmis spp. \\
\hline Chironomus spp. \\
\hline Cryptotendipes sp. \\
\hline Dicrotendipes simpsoni \\
\hline Kiefferulus dux \\
\hline Phaenopsectra flavipes \\
\hline Polypedilum fallax \\
\hline Polypedilum spp. \\
\hline Tribelos fuscicorne \\
\hline Tribelos jucundum \\
\hline Ceratopogonidae \\
\hline Hemerodromia spp. \\
\hline Palpomyia spp. \\
\hline Telmatoscopus sp. \\
\hline Corynoneura spp. \\
\hline Cricotopus/Ortho spp. \\
\hline Thienemanniella spp. \\
\hline Ablabesmyia spp. \\
\hline Conchapelopia spp. \\
\hline Labrundinia spp. \\
\hline Paramerina sp. \\
\hline Zavrelimyia sp. \\
\hline Tanytarsus spp. \\
\hline Stenonema spp. \\
\hline Nigronia serricornis \\
\hline Ferrissia sp. \\
\hline Argia sp. \\
\hline Boyeria vinosa \\
\hline Calopteryx sp. \\
\hline Enallagma sp. \\
\hline Progomphus sp. \\
\hline Allocapnia spp. \\
\hline Diplectrona modesta \\
\hline Lype diversa \\
\hline
\end{tabular}




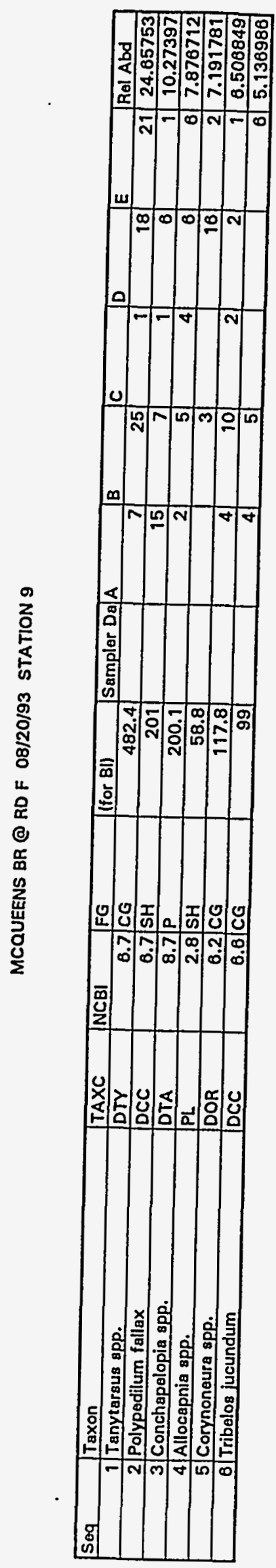




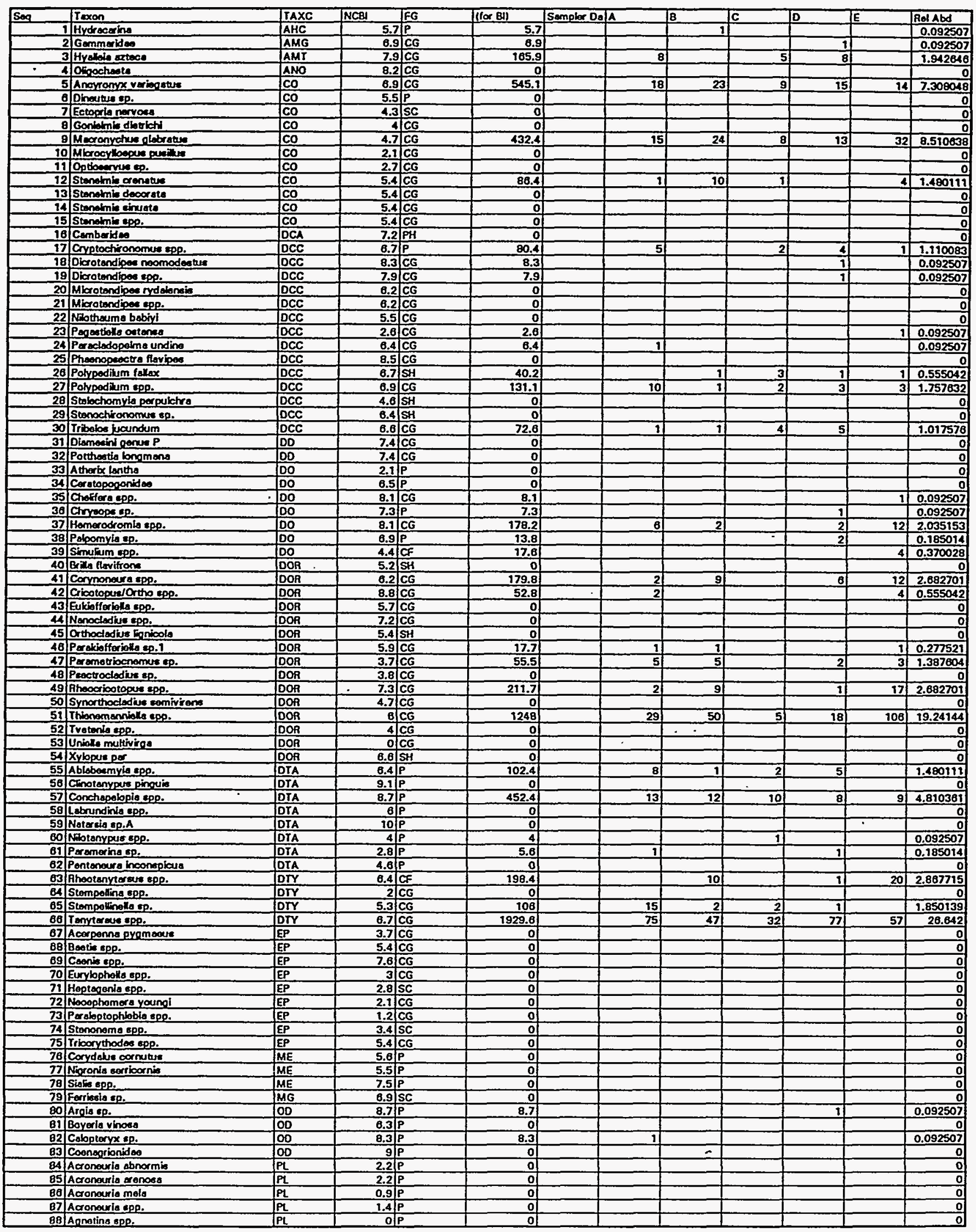




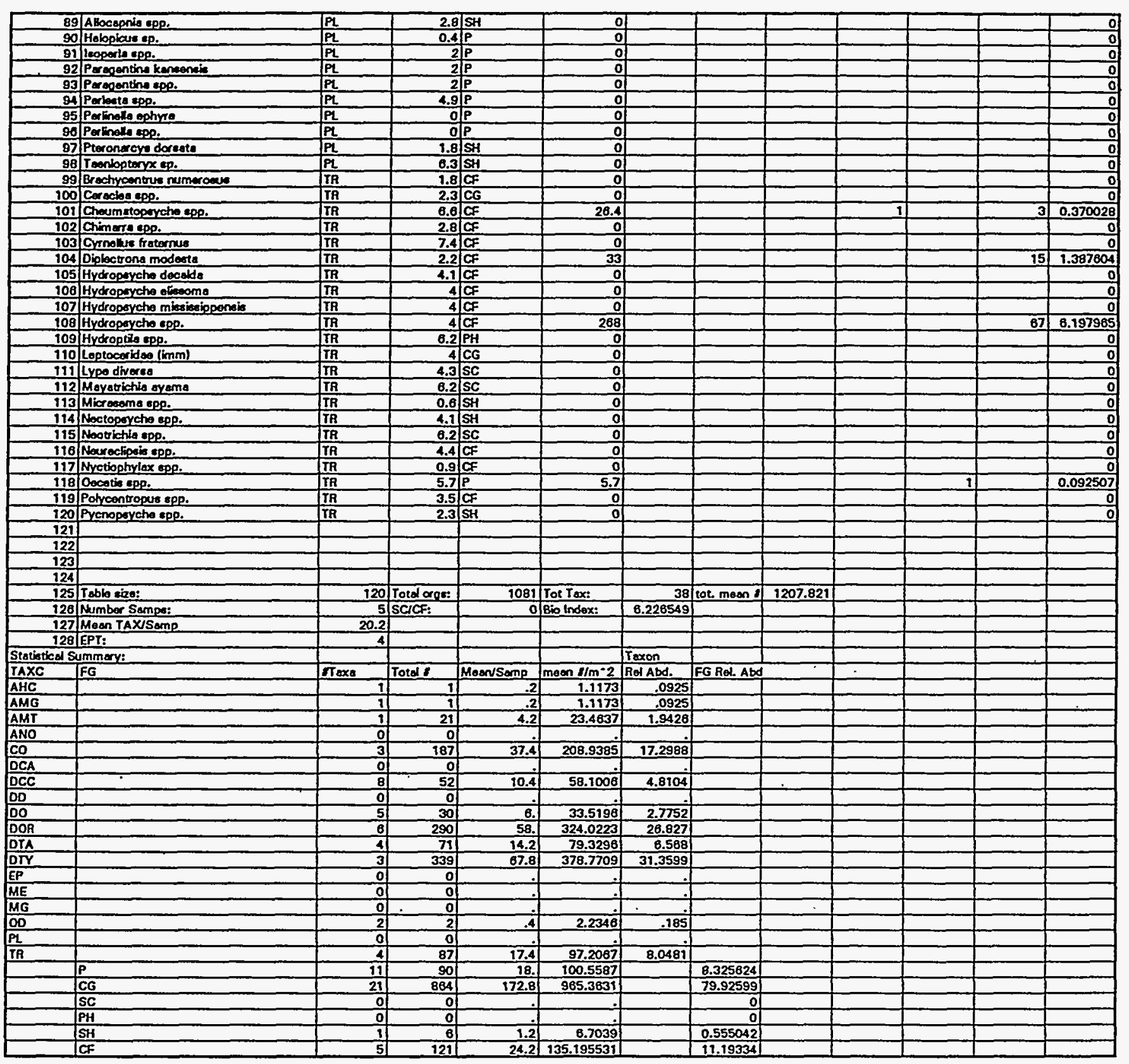




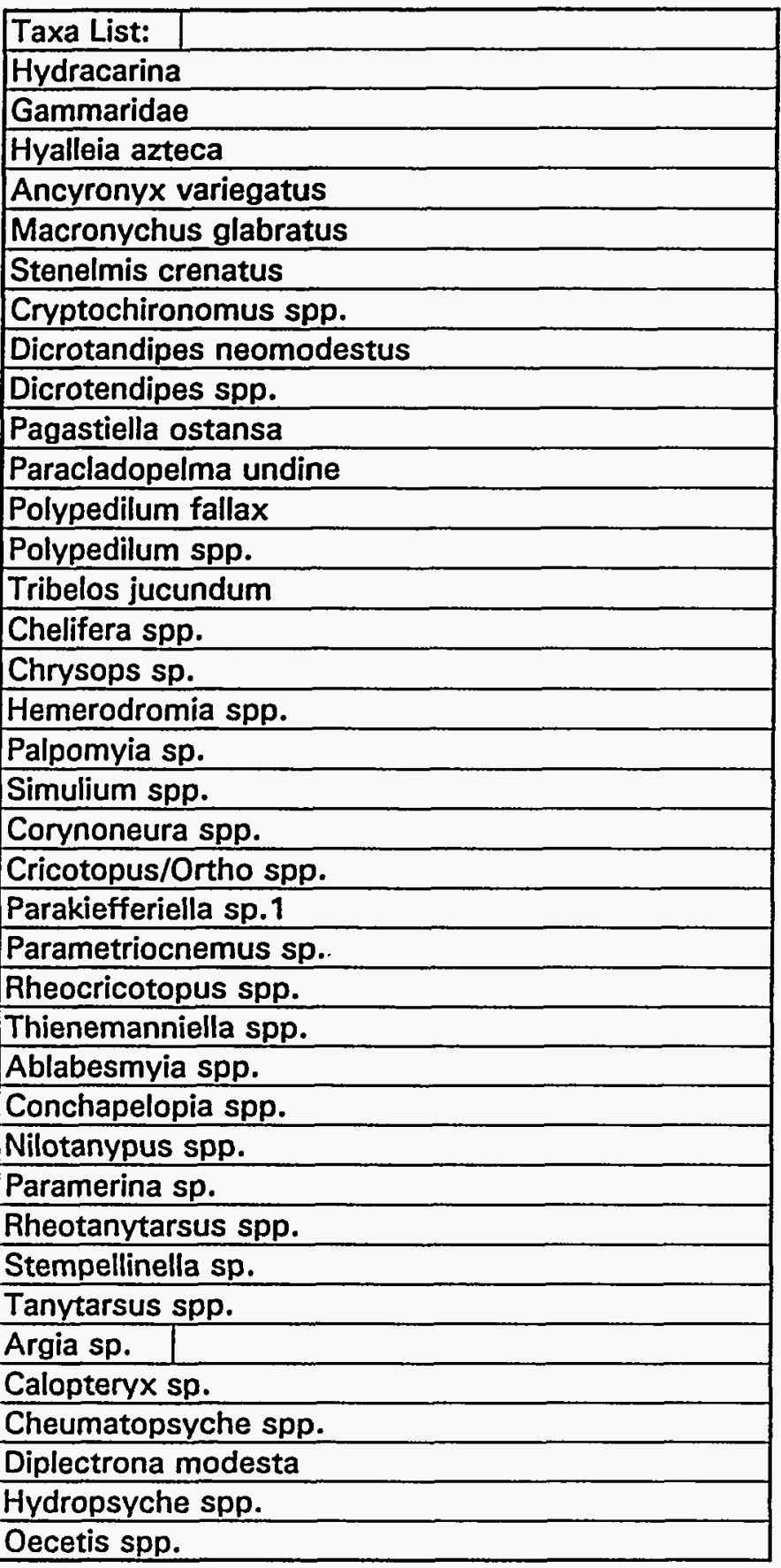




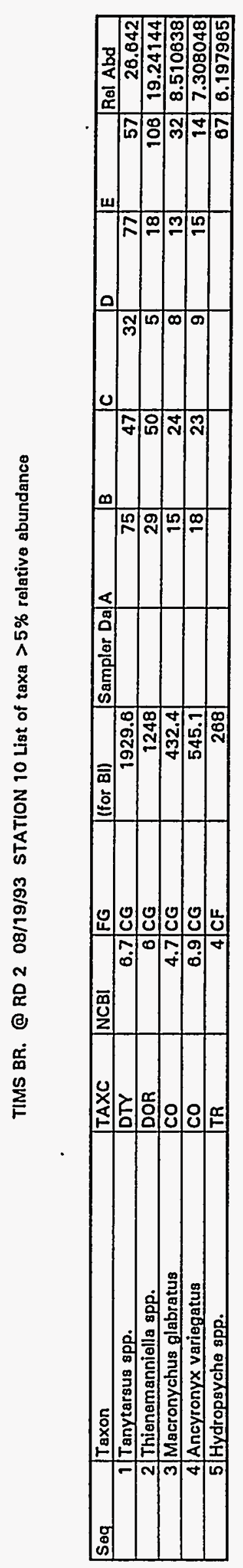




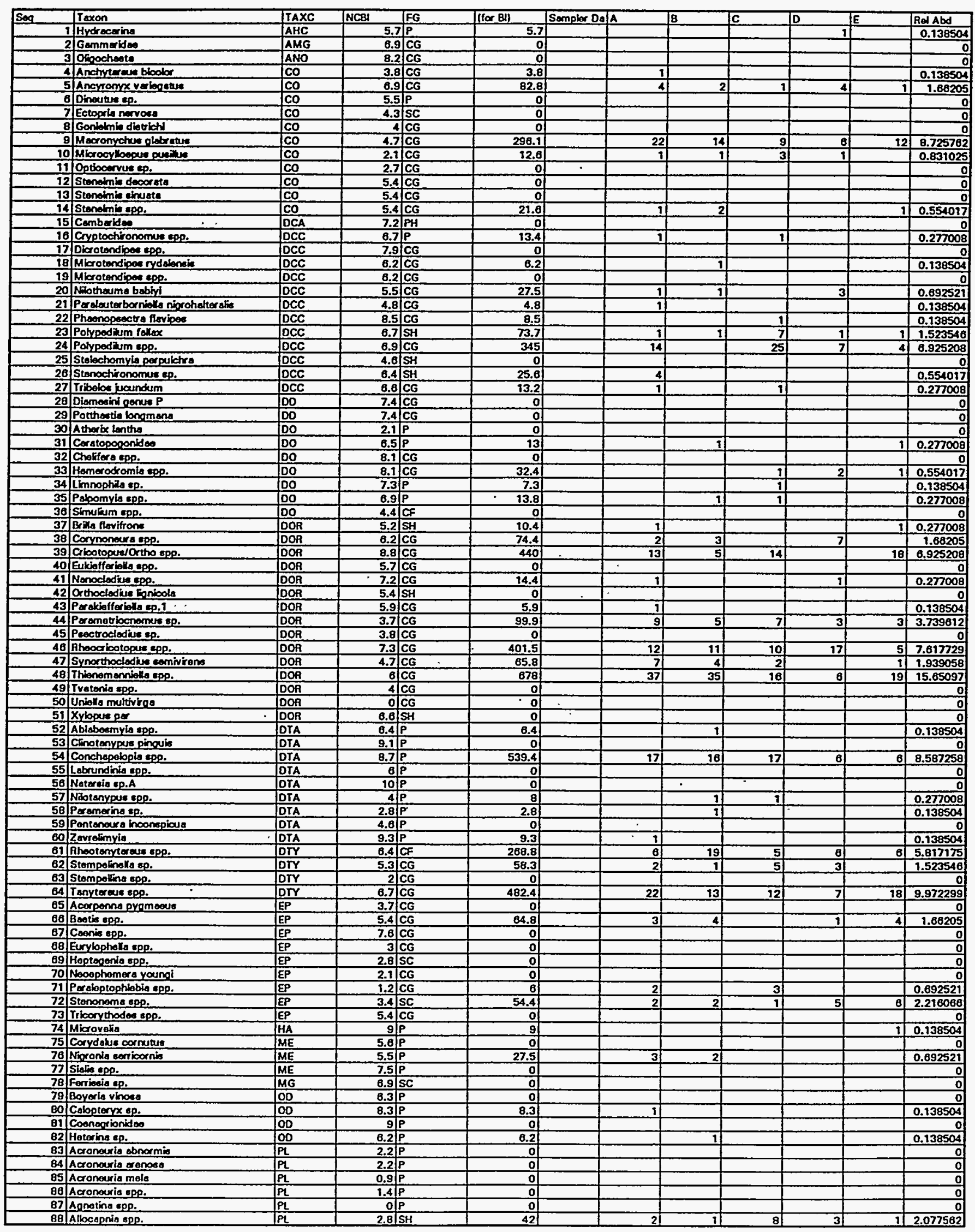




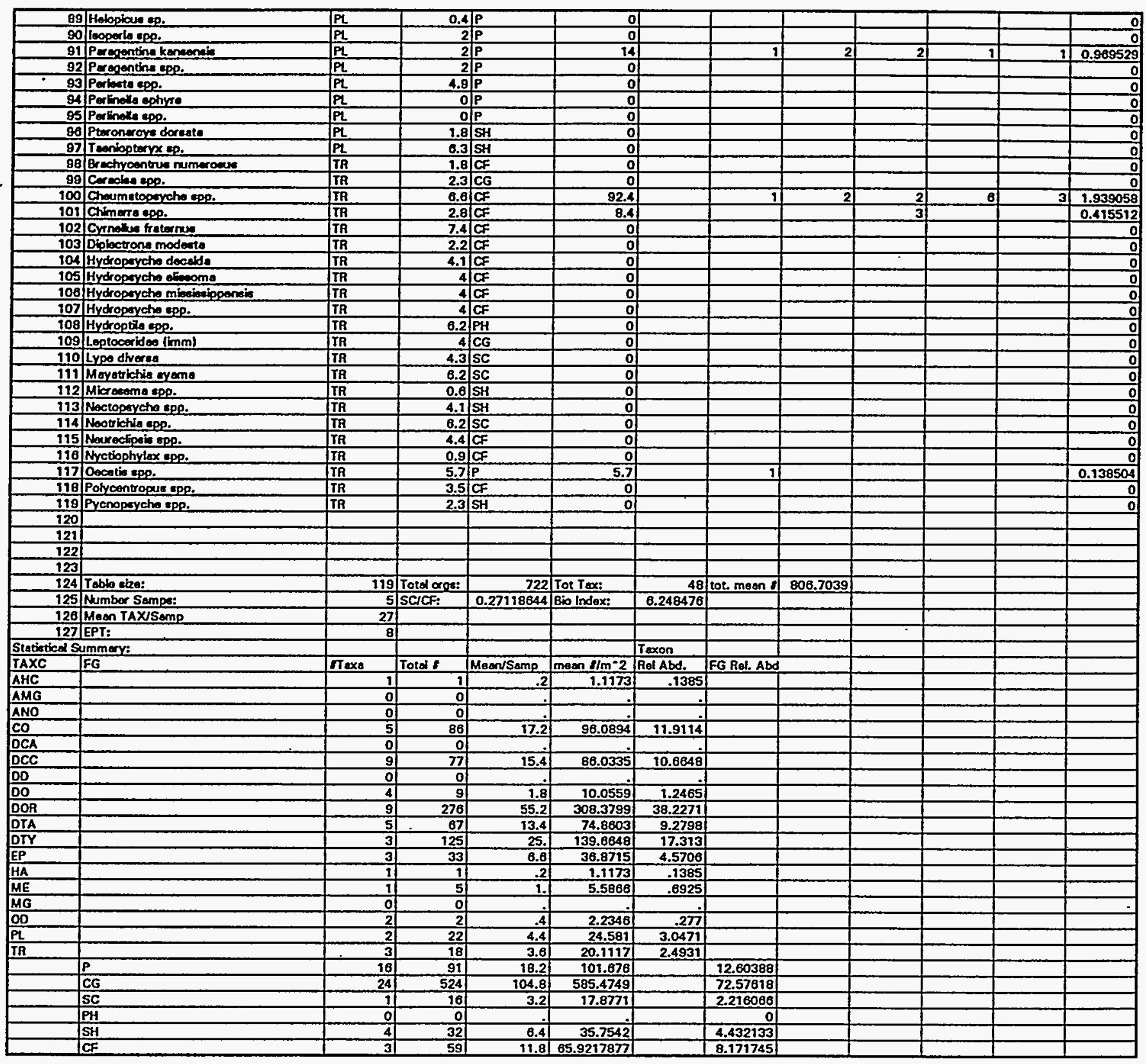




\begin{tabular}{|l|}
\hline Taxa List: \\
\hline Hydracarina \\
\hline Arichytarsus bicolor \\
\hline Ancyronyx variegatus \\
\hline Macronychus glabratus \\
\hline Microcylloepus pusillus \\
\hline Stenelmis spp. \\
\hline Cryptochironomus spp. \\
\hline Microtendipes rydalensis \\
\hline Nilothauma babiyi \\
\hline Paralauterborniella nigrohalteralis \\
\hline Phaenopsectra flavipes \\
\hline Polypedilum fallax \\
\hline Polypedilum spp. \\
\hline Stenochironomus sp. \\
\hline Tribelos jucundum \\
\hline Ceratopogonidae \\
\hline Hemerodromia spp. \\
\hline Limnophila sp. \\
\hline Palpomyia spp. \\
\hline Brilla flavifrons \\
\hline Corynoneura spp. \\
\hline Cricotopus/Ortho spp. \\
\hline Nanocladius spp. \\
\hline Parakiefferiella sp.1 \\
\hline Parametriocnemus sp. \\
\hline Rheocricotopus spp. \\
\hline Synorthocladius semivirens \\
\hline Thienemanniella spp. \\
\hline Ablabesmyia spp. \\
\hline Conchapelopia spp. \\
\hline Nilotanypus spp. \\
\hline Paramerina sp. \\
\hline Zavrelimyia \\
\hline Rheotanytarsus spp. \\
\hline Stempelinella sp. \\
\hline Tanytarsus spp. \\
\hline Baetis spp. \\
\hline Paraleptophlebia spp. \\
\hline Stenonema spp. \\
\hline Microvelia \\
\hline Nigronia serricornis \\
\hline Calopteryx sp. \\
\hline Heterina sp. \\
\hline Pllocapnia spp. \\
\hline Cheumatina kansensis \\
\hline
\end{tabular}




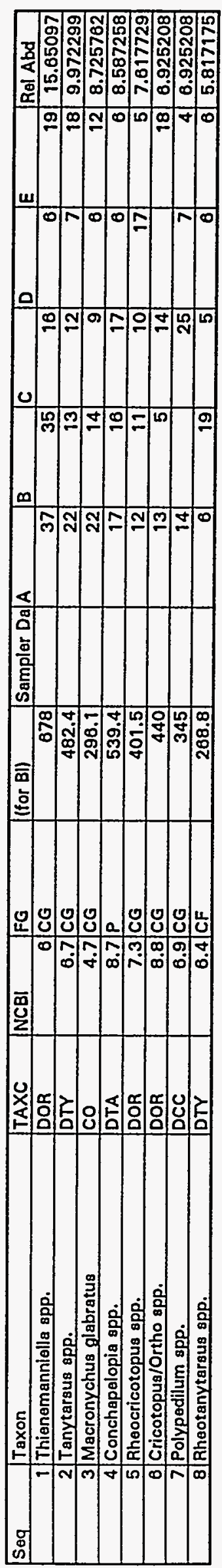




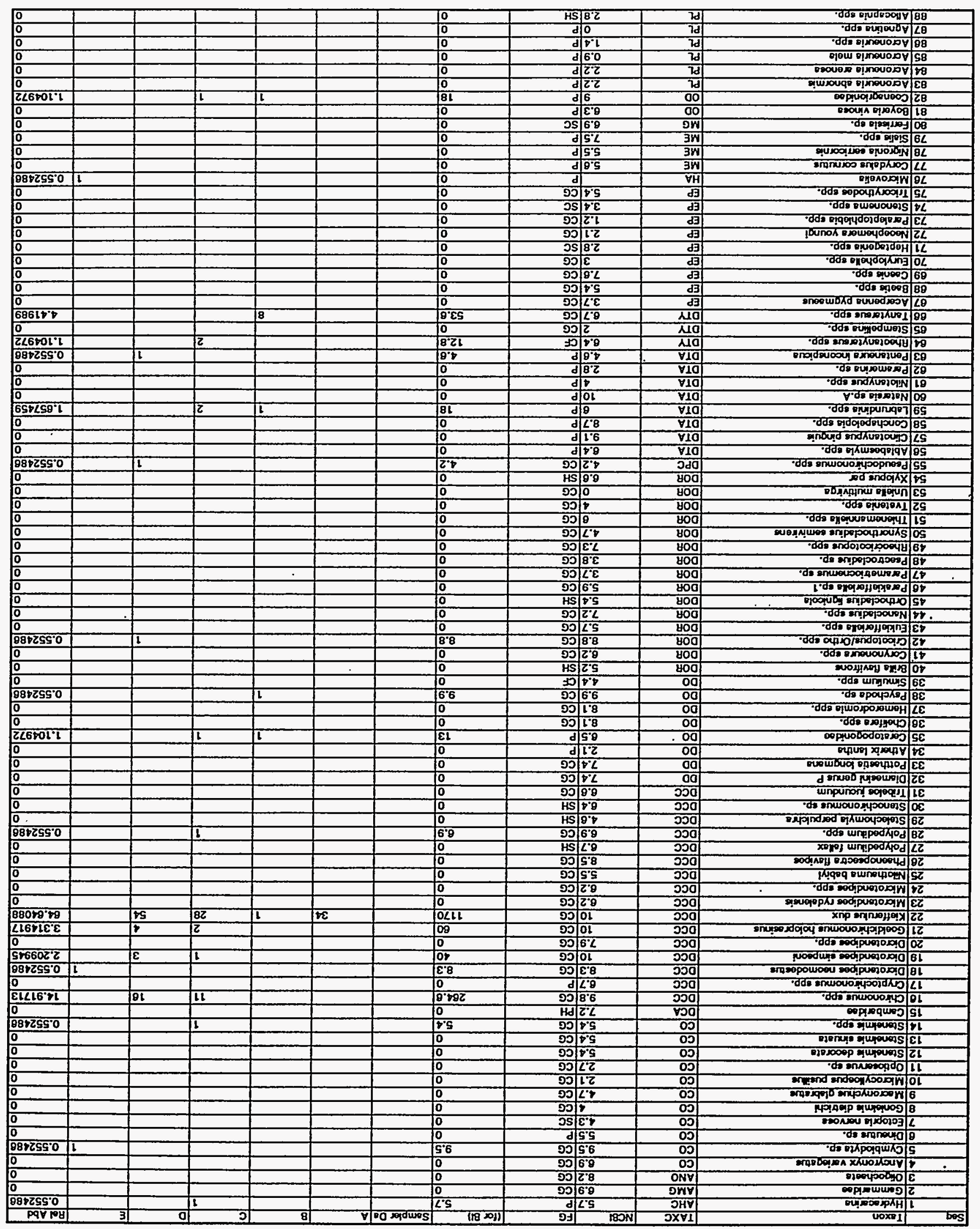




\begin{tabular}{|c|c|c|c|c|c|c|c|c|c|c|c|c|}
\hline 89 & Holopiare is. & $P$ PL & 0.4 & P & of & & & & & & & 은 \\
\hline 90 & leoperta epp. & $P L$ & 2 & P & of & & & & & & & a) \\
\hline 81 & Pergentine keneencis & PL. & 2 & $P$ & of & & & & & & & 의 \\
\hline 92 & Parepentin epp. & $P L$ & 2 & $p$ & of & & & & & & & 의 \\
\hline 83 & Parbeta epo. & $P L$ & 4.9 & $P$ & of & & & & & & & 의 \\
\hline 94 & Perlinelle ephre & PL & of & P & of & & & & & & & 의 \\
\hline 95 & Perinale epp. & PL & 요 & $P$ & 0 & & & & & & & 요 \\
\hline 90 & Ptoronfoye dorente & $\mathbf{P L}$ & 1.8 & SH & 0 & & & & & & & 의 \\
\hline 97. & Taeniopteryx ep. & $P L$ & 6.3. & SH & 의 & & & & & & & 의 \\
\hline 88 & Brecturcentive numeroeves & TR & 1.8 & CF & of & & & & & & & 으 \\
\hline 99 & Corscles epp. & IR & 2.3 & CG & 요 & & & & & & & 의 \\
\hline 100 & Choum atoperychepe. & IR & 6.6) & CF & of & & & & & & & 0 \\
\hline 101 & Chimerrespe. & ITR & 2.8 & CF & of & & & & & & & 으 \\
\hline 102 & Cyrnolive fraternue & TA & 7.4 & CF & 아 & & & & & & & 의 \\
\hline 103 & Diplectrona modecta & TR & 2.2 & CF & of & & & & & & & 의 \\
\hline 104 & Hydroperycha deceida & TA & 4.1 & CF & of & & & & & & & a) \\
\hline 105 & Hydropereche ofieoms & TR & $4 \sqrt{1}$ & CF & of & & & & & & & of \\
\hline 100 & Hrokopeycho mivienipponeis & TR & 4) & CF & of & & & & & & & 의 \\
\hline 107 & Hroroperche epp. & TR & 4 & $C F$ & of & & & & & & & 의 \\
\hline 108 & Hydroptio epe. & TR & 6.2 & $\mathrm{PH}$ & of & & & & & & & 의 \\
\hline 109 & Loptocerideo (imm) & TR & 4 & CG & 의 & & & & & & & 은 \\
\hline 110 & Lype diveres & TR & 4.3 & SC & of & & & & & & & 의 \\
\hline 111 & Moyatrichia ayema & TR & 6.2 & SC. & of & & & & & & & 의 \\
\hline 112 & Miarosoma epp. & TR & 0.6 & SH & of & & & & & & & 의 \\
\hline 113 & Noctopeycho epp. & TR & 4.1. & SH & of & & & & & & & 의 \\
\hline 114 & Neourtchio epp. & IR & 6.2 & SC & of & & & & & & & 의 \\
\hline 115 & Noureclipsin spe. & TR & 4.4 & CF & of & & & & & & & 의 \\
\hline 116 & Nyctiophytex cpp. & IR & 0.9 & CF & of & & & & & & & 의 \\
\hline 117 & Oocotis app. & TR & 5.7 & $\mathbf{P}$ & of & & & & & & & 의 \\
\hline 118 & Polycentropuse epe. & IR & 3.5 & CF & of & & & & & & & 0 \\
\hline 119 & Pycnopeyche sop. & IR & 2.3 & $S H$ & of & & & & & & & 의 \\
\hline \multicolumn{13}{|l|}{120} \\
\hline \multicolumn{13}{|l|}{121} \\
\hline \multicolumn{13}{|l|}{122} \\
\hline \multicolumn{13}{|l|}{123} \\
\hline 124 & Toblo sizo: & 119 & Fotal orge: & 181 & Tot Tax: & 19 & tot. meen 8 & 202.2346 & & & & \\
\hline 125 & Number Somps: & 5 & SCICF: & 요 & Bia Index: & 9.465746 & & & & & & \\
\hline 126 & Mosen TAXUSemp & 5.6 & & & & & & & & & & \\
\hline \multicolumn{13}{|c|}{ 127 EPT: } \\
\hline Statintical Su & Ummery: & & & & & Taxon & & & & & & \\
\hline TAXC & $\mathbf{F G}$ & $\operatorname{Traxa}$ & Totad 8 & MoandSamp & mean $/ m^{*} 2$ & Rel Abd. & FG Rel Abd & & & & & \\
\hline AHC & & 1) & 1 & .2 & 1.1173 & .5525 & & & & & & \\
\hline AMGG & & of & 이 & & .1 & & & & & & & \\
\hline ANO & & of & o. & & & & & & & & & \\
\hline $\mathrm{CO}$ & & 2 & 2 & .4 & 2.2346 & 1.105 & & & & & & \\
\hline DCA & & of & of & & & & & & & & & \\
\hline$\overline{D C C}$ & & 6 & 158 & 31.2 & 174.3017 & 86.1878 & & & & & & \\
\hline DD & & 의 & 의 & I & & & & & & & & \\
\hline DO & & 2 & 3 & .6 & 3.352 & 1.6575 & & & & & & \\
\hline DOA & & 1 & 1 & .2 & 1.1173 & .5525 & & & & & & \\
\hline DPC & & I & 1 & .2 & 1.1173 & .5525 & & & & & & \\
\hline DTA & & 21 & 4 & .8 & 4.4693 & 2.2099 & & & & & & \\
\hline DTY & & 2 & 10 & 2. & 11.1732 & 5.5249 & & & & & & \\
\hline EP & & of & of & & & & & & & & & \\
\hline HA & & II & 1 & .2 & 1.1173 & .5525 & & & & & & \\
\hline $\mathrm{ME}$ & & of & of & .1 & - & it & & & & & & \\
\hline MG & & of & 이 & & & & & & & & & \\
\hline$O D$ & & 11 & 2 & .4 & 2.2346 & 1.105 & & & & & & \\
\hline P & & of & of & & & & & & & & & \\
\hline IR & & of & of & & & & & & & & & \\
\hline & $P$ & 6) & 10 & 2.1 & 11.1732 & & 5.524862 & & & & & \\
\hline & CG & 12 & 169 & 33.8 & 188.8268 & & 93.37017 & & & & & \\
\hline & Sc & of & of & 4 &. & & of & & & & & \\
\hline & $P H$ & 이 & of & & & & 의 & & & & & \\
\hline & SH & of & 의 & & +1 & & 아 & & & & & \\
\hline & CF & 1) & 21 & 0.4 & 2.23463687 & & 1.104972 & & & & & \\
\hline
\end{tabular}


Taxa List:

Hydracarina

Cymbiodyta sp.

Stenelmis spp.

Chironomus spp.

Dicrotendipes neomodestus

Dicrotendipes simpsoni

Goeldichironomus holoprasinus

Kiefferulus dux

Polypedilum spp.

Ceratopogonidae

Psychoda sp.

Cricotopus/Ortho spp.

Pseudochironomus spp.

Labrundinia spp.

Pentaneura inconspicua

Rheotanytarsus spp.

Tanytarsus spp.

Microvelia

Coenagrionidae 


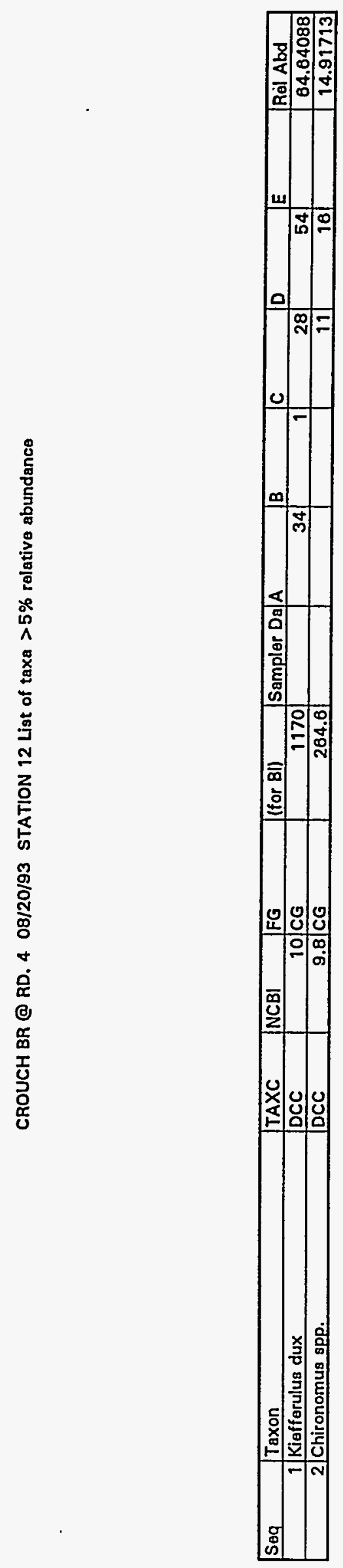




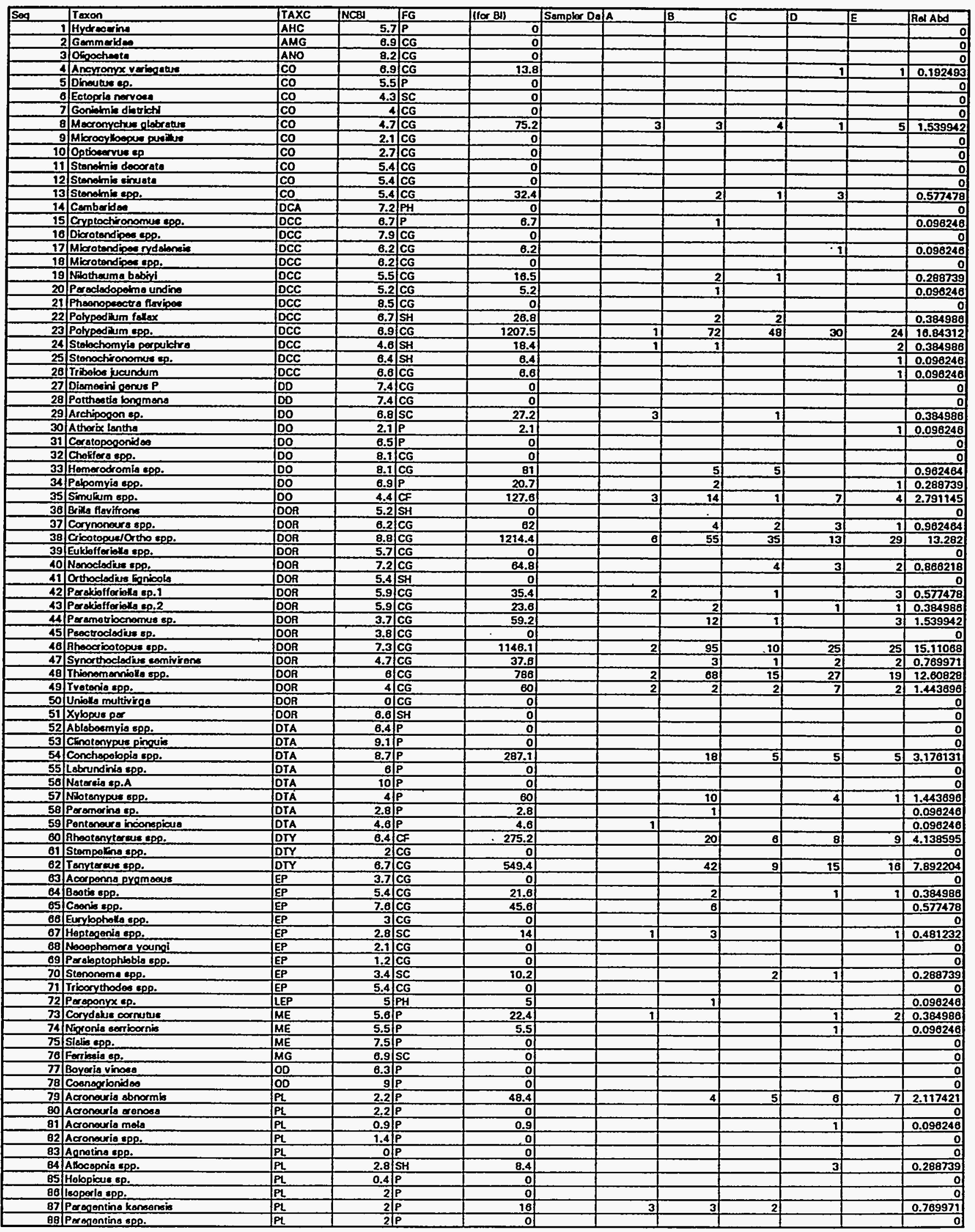




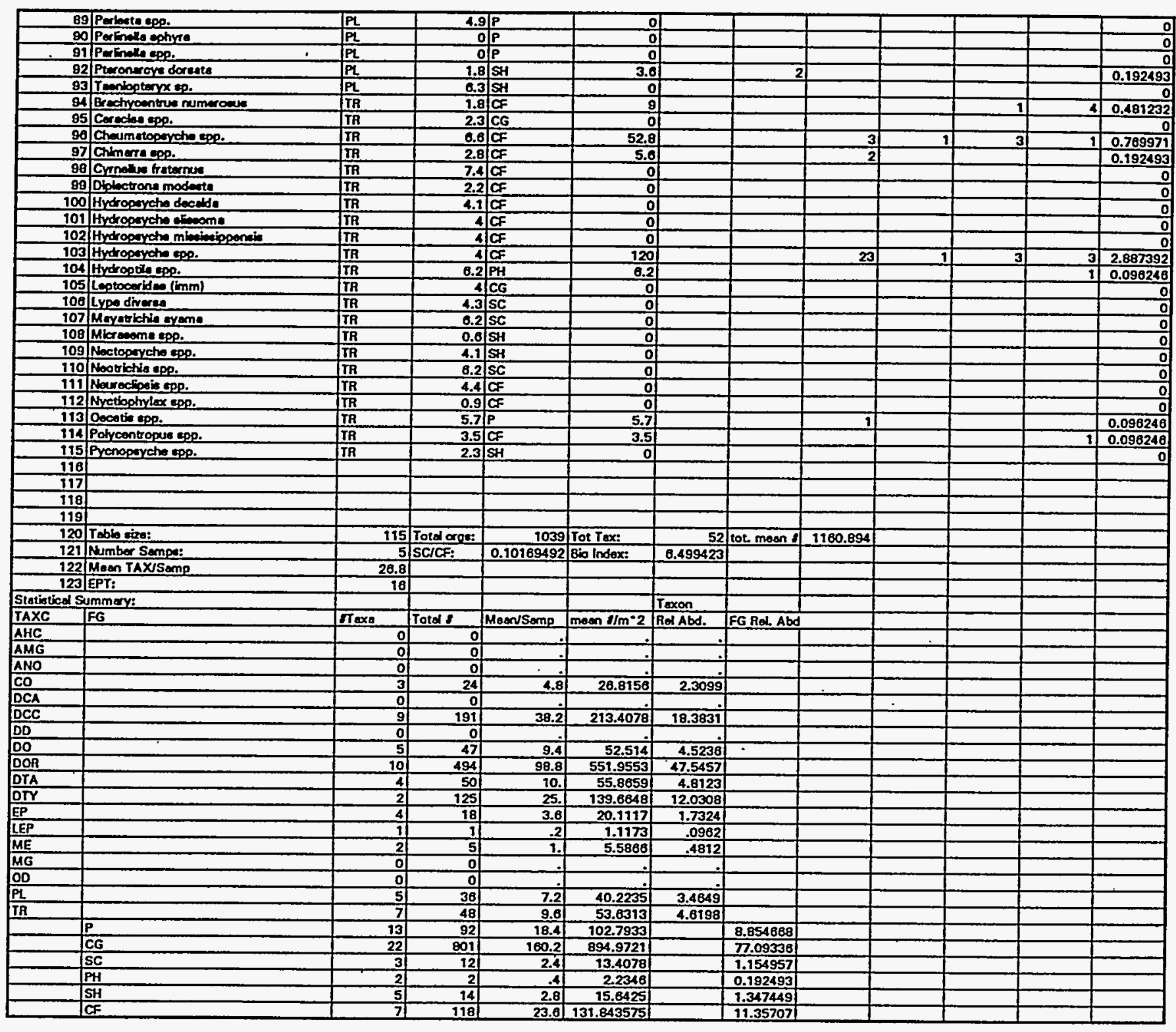




\begin{tabular}{|l|}
\hline Taxa List: \\
\hline Ancyronyx variegatus \\
\hline Macronychus glabratus \\
\hline Stenelmis spp. \\
\hline Cryptochironomus spp. \\
\hline Microtendipes rydalensis \\
\hline Nilothauma babiyi \\
\hline Paracladopelma undine \\
\hline Polypedilum fallax \\
\hline Polypedilum spp. \\
\hline Stelechomyia perpulchra \\
\hline Stenochironomus sp. \\
\hline Tribelos jucundum \\
\hline Archipogon sp. \\
\hline Atherix lantha \\
\hline Hemerodromia spp. \\
\hline Palpomyia spp. \\
\hline Simulium spp. \\
\hline Corynoneura spp. \\
\hline Cricotopus/Ortho spp. \\
\hline Nanocladius spp. \\
\hline Parakiefferiella sp.1 \\
\hline Parakiefferiella sp.2 \\
\hline Parametriocnemus sp. \\
\hline Rheocricotopus spp. \\
\hline Synorthocladius semivirens \\
\hline Thienemanniella spp. \\
\hline Tvetenia spp. \\
\hline Conchapelopia spp. \\
\hline Nilotanypus spp. \\
\hline Paramerina sp. \\
\hline Pentaneura inconspicua \\
\hline Rheotanytarsus spp. \\
\hline Tanytarsus spp. \\
\hline Baetis spp. \\
\hline Caenis spp. \\
\hline Heptagenia spp. \\
\hline Stenonema spp. \\
\hline Paraponyx sp. \\
\hline Corydalus cornutus \\
\hline Nigronia serricornis \\
\hline Acroneuria abnormis \\
\hline Acroneuria mela \\
\hline Allocapnia spp. \\
\hline Paragentina kansensis \\
\hline Pteronarcys dorsata \\
\hline Brachycentrus numerosus \\
\hline Cheumatopsyche spp. \\
\hline Chimarra spp. \\
\hline
\end{tabular}


UTR RD C 08/20/93 STATION 13

Hydropsyche spp.

Hydroptila spp.

Oecetis spp.

Polycentropus spp. 


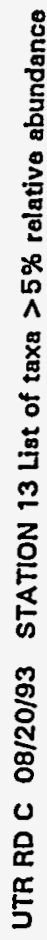

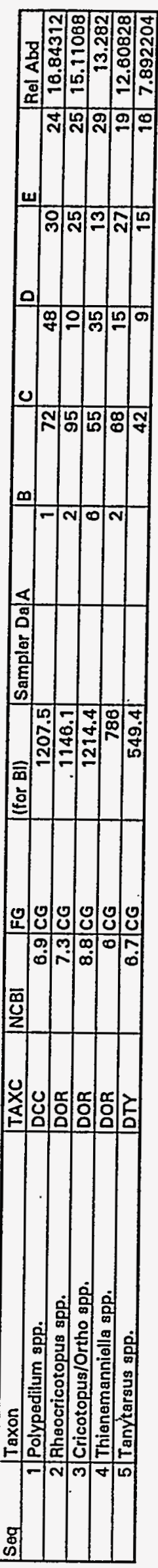




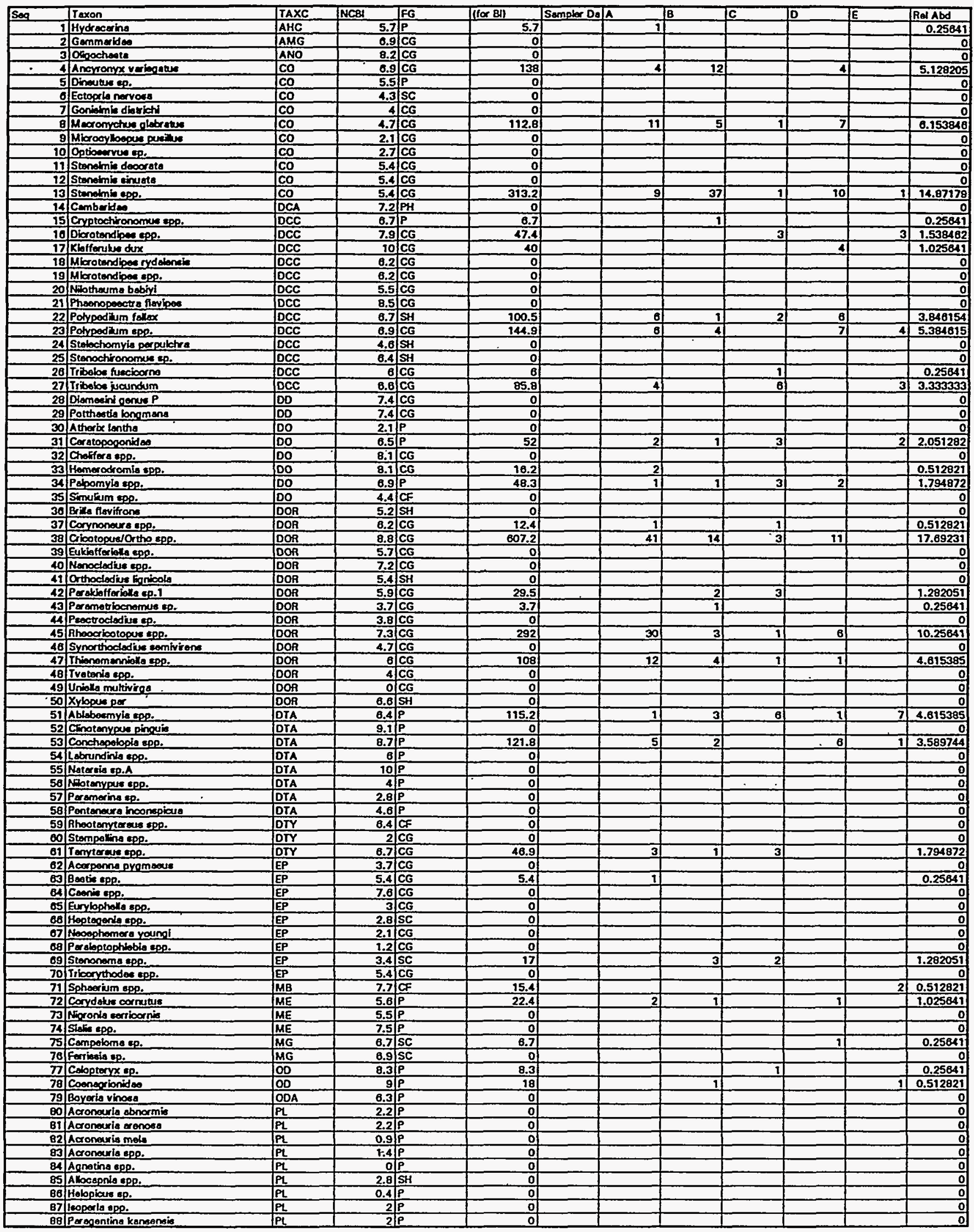




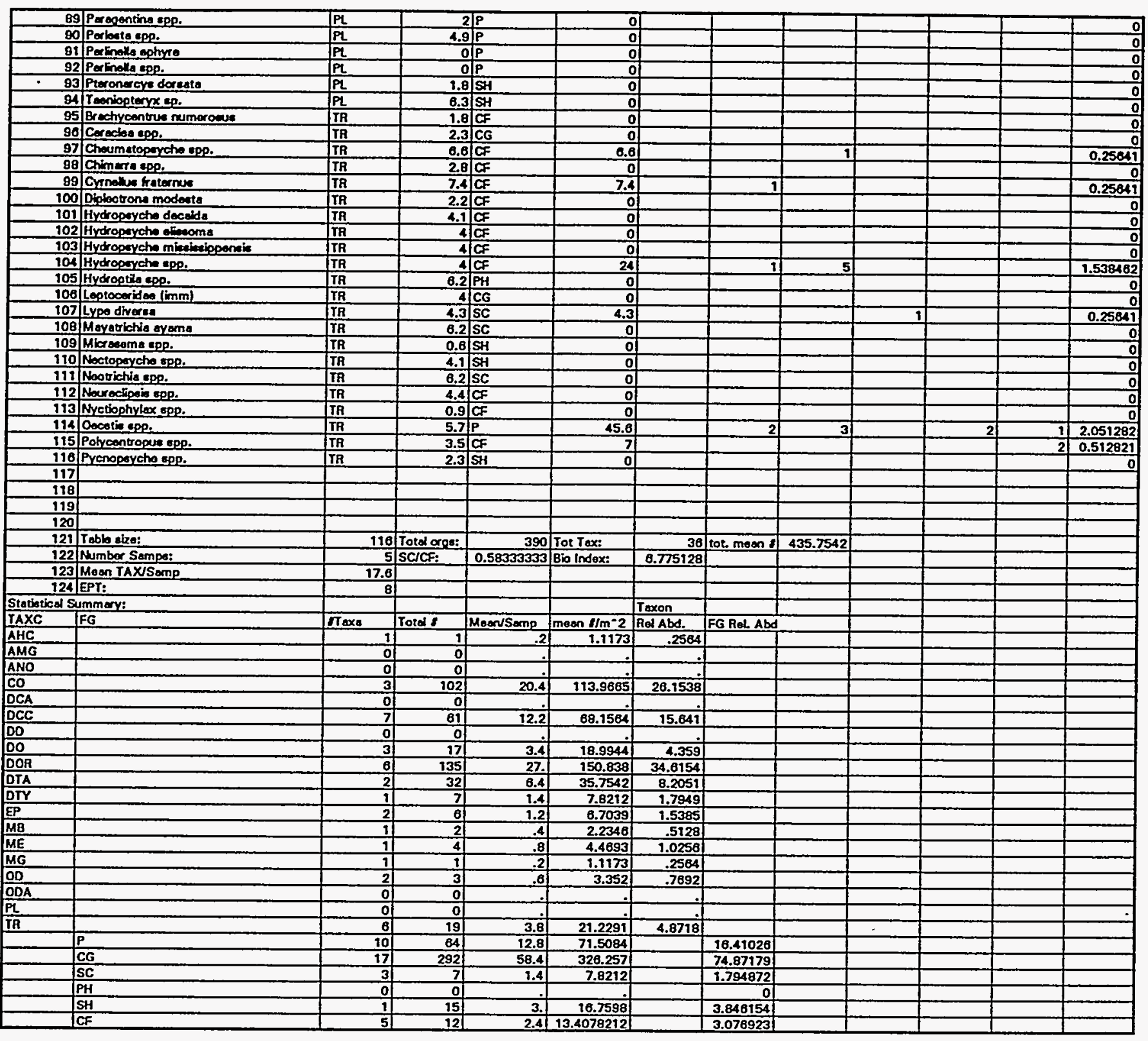


FMC RD C-4 08/20/93 STATION 14

\begin{tabular}{|l|}
\hline Taxa List: \\
\hline Hydracarina \\
\hline Ancyronyx variegatus \\
\hline Macronychus glabratus \\
\hline Stenelmis spp. \\
\hline Cryptochironomus spp. \\
\hline Dicrotendipes spp. \\
\hline Kiefferulus dux \\
\hline Polypedilum fallax \\
\hline Polypedilum spp. \\
\hline Tribelos fuscicorne \\
\hline Tribelos jucundum \\
\hline Ceratopogonidae \\
\hline Hemerodromia spp. \\
\hline Palpomyia spp. \\
\hline Corynoneura spp. \\
\hline Cricotopus/Ortho spp. \\
\hline Parakiefferiella sp.1 \\
\hline Parametriocnemus sp. \\
\hline Rheocricotopus spp. \\
\hline Thienemanniella spp. \\
\hline Ablabesmyia spp. \\
\hline Conchapelopia spp. \\
\hline Tanytarsus spp. \\
\hline Baetis spp. \\
\hline Stenonema spp. \\
\hline Sphaerium spp. \\
\hline Corydalus cornutus \\
\hline Campeloma sp. \\
\hline Calopteryx sp. \\
\hline Coenagrionidae \\
\hline Cheumatopsyche spp. \\
\hline Cyrnellus fraternus \\
\hline Hydropsyche spp. \\
\hline Lype diversa \\
\hline Oecetis spp. \\
\hline Polycentropus spp. \\
\hline
\end{tabular}




\begin{tabular}{|c|c|c|c|c|c|c|c|c|c|c|c|c|}
\hline Seq & Taxon & TAXC & NCBI & FG & (for BI) & Sampler Da & $\bar{A}$ & $B$ & C & D & $E$ & Rel Abd \\
\hline 1 & Cricotopus/Ortho spp. & DOR & 8.8 & CG & 607.2 & & 41. & 14 & 3 & 11 & & 17.69231 \\
\hline 2 & Stenelmis spp. & Co & 5.4 & $C G$ & 313.2 & & 9 & 37 & 1 & 10 & 1 & 14.87179 \\
\hline 3 & Rheocricotopus spp. & DOR & 7.3 & CG & 292 & & 30 & 3 & 1 & 6 & & 10.25641 \\
\hline 4 & Macronychus glabratus & $\mathrm{CO}$ & 4.7 & CG & 112.8 & & 11 & 5 & 1 & 7 & & 6.153846 \\
\hline 5 & Polypedilum spp. & $D C C$ & B.9 & CG & 144.9 & & B & 4 & & 7 & 4 & 5.384615 \\
\hline & Ancyronyx variegatus & Co & 6.9 & ICG & 138 & & 4 & 12 & & 4 & & 5.128205 \\
\hline
\end{tabular}




\begin{tabular}{|c|c|c|c|c|c|c|c|c|c|}
\hline Sog & Traon & $T \wedge \times C$ & NCBI & FEG & (for Bin & Sampleor Da & IA & $F_{B}$ & 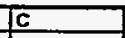 \\
\hline & i Hydtecerint & AHC & 5.7 & $P$ & 0 & & & & \\
\hline & 2 Gemm ridoo & AMG & 8.9 & GG & 0 & & & & \\
\hline & 3 Hirudines sp. & ANH & 8.2 & & 8.2 & & 1 & if & \\
\hline$\because$ & 1 OFogotroale & fano & 8.2 & ICG & 0 & & & & \\
\hline & 5 Ancyrompx velegatur & co & 0.9 & AcG & 0 & & & & \\
\hline & 6 Dinoubue ap. & Co & 5.5 & $P$ & 으 & & & & \\
\hline & 7 Ectoprie nervoes & co & 4.3 & 56 & 0 & & & & \\
\hline 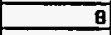 & 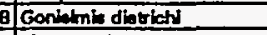 & co & & 60 & $\overline{0}$ & & & & \\
\hline & 9 Mecronyohin glebretere & co & 4.7 & CG & 0 & & & & \\
\hline 10 & of Mlorog yloopus puritury & co & 2.2 & CG & 0 & & & & \\
\hline 11 & 1 optionervue sp. & co & 2.7 & CG & 0 & & & & \\
\hline 12 & 2 stuncimis decorath & $+\infty$ & 5.4 & CG & 0 & & & & \\
\hline 13 & 3 Stondmic sinusats & $\mathrm{CO}$ & 5.4 & CG & $\mathbf{0}$ & & & & \\
\hline 14 & 4 stondmin cpp. & Co & 5.4 & CG & 0 & & & & \\
\hline 15 & 5 comberides & JoCA & 7.2 & $P A$ & 0 & & & & \\
\hline 10 & $\begin{array}{c}\text { a Chironompre epp. } \\
\end{array}$ & DCC & 9.8 & CG & 19.6 & & & & 2 \\
\hline 17 & $\overline{7}$ Cryplochironomulesp. & DCC & 6.7 & & 0 & & & & \\
\hline 18 & 8) Ditarocondipen epp. & DCC & 7.9 & $\mathbf{C G}$ & o & & & & \\
\hline 19 & 9 Milerotondipes rydolonsio & DOCC & 0.2 & CG & o & & & & \\
\hline 20 & Ollatotondiposespo. & DocC & 6.2 & CG & 0 & & & & \\
\hline 21 & INeothoum bobini & DCC & 5.5 & CG & 0 & & & & \\
\hline 22 & 2 Proeonopectra flarioes & DCC & 8.5 & CG & 0 & & & & \\
\hline 23 & 3 Pohyodien follex & DCC & 8.7 & \$ & 0 & & & & \\
\hline 24 & Potypeditum epg. & Locc & 8.9 & Co & 0 & & & & \\
\hline 25 & 5 Stelochom ris perpulctre & $D C C$ & 4.0 & SH & 의 & & & & \\
\hline 26 & 1) Stenochironomus Ep. & Docc & 0.4 & SH & 의 & & & & \\
\hline 27 & 7 Tribeloe waundum & DCC & 6.8 & CG & 8.6 & & 1 & & \\
\hline 28 & Diomosin genus $P$ & Do & 7.4 & CG & of & & & & \\
\hline 29 & Potthertis bongmene & $\frac{100}{100}$ & 7.4 & CG & 0 & & & & \\
\hline 30 & Atherio lonthe & DO & 2.1 & & of & & & & \\
\hline (31) & Ceratopoponides & Do & 8.5 & P & 의 & & & & \\
\hline 32 & 2 Choffere app. & DO & 8.1 & CG & of & & & & \\
\hline 33 & Hernerodromia spp. & Do & 8.1 & CG & 0 & & & & \\
\hline 34 & IS Sinulium Epp. & 100 & 4.4 & CF & of & & & & \\
\hline 35 & Brita flavifions & DOR & 5.2 & SH & of & & & & \\
\hline 36 & Sarynonara spp. & DOR & 6.2 & CG & 의 & & & & \\
\hline 37 & Criootopued ontho spp. & DOR & 8.8 & CG & of & & & & \\
\hline 38 & Eukbofferiots sop. & DOR & 5.7 & C6 & 0 & & & & \\
\hline 39 & Nonoctodises gpe. & DOR & 7.2 & CG & of & & & & \\
\hline 40 & Orthoctedius Eonioola & DOR & 5.4 & SH & af & & & & \\
\hline 11 & Peratefferibla cp.1 & DOR & 5.9 & CG & of & & & & \\
\hline 12 & Preamatibcromus ep. & DOR & 3.7 & CG & of & & & & \\
\hline 43 & Prectrocledivas sp. & TOOR & 3.8 & CG & of & & & & \\
\hline 44 & Al prococicotopus epp. & DOR & 7.3 & CG & - & & & & \\
\hline 45 & Synorthodedives samivions & DOR & 4.7 & CG & of & & & & \\
\hline 40 & Thionamennisto spp. & DOR & & $C G$ & of & & & & \\
\hline 47 & Trotenis epp. & DOA & 4 & CG & of & & & & \\
\hline 48 & Uniols mutrivirge & DOA & of & CG & of & & & & \\
\hline 48 & Xylopue per & DOA & 6.8 & SH & of & & & & \\
\hline 50 & Ablaboemyio spp. & DTA & 6.4 & $P$ & of & & & & \\
\hline 51 & Cenolsmypur pinquis & DTA & 9.1 & P & of & & & & \\
\hline 52 & Conchopolopla sepe. & fora & 8.7 & & of & & & & \\
\hline 53 & Labrundinis spo. & DTA & & P & of & & & & \\
\hline 54 & Matoreis sp.A & TOTA & 10 & $P$ & of & & & & \\
\hline 55 & i Nootanypus epp. & DTA & 4 & P & of & & & & \\
\hline $56 / 1$ & Promerina ep. & DTA & 2.8 & $\mathbf{P}$ & of & & & & \\
\hline 57/ & Penteneera inconspiala & DTA & 4.6 & $\mathbf{P}$ & of & & & & \\
\hline 56 & Tihootonyemous spp. & DTr & 0.4 & CEF & a & & & & \\
\hline 59 & Stompens cop. & DTY & 2 & CG & of & & & & \\
\hline 001 & Tompresues spp. & DTY & 6.7 & CG & of & & & & \\
\hline 61 & Acorpans pyom aous & JEP & 3.7 & CG & of & & & & \\
\hline 62 & Beatis spe. & EEP & 5.4 & CG & 0 & & & & \\
\hline 63 (c) & Coonis spe. & EPP & 7.8 & CG & 0 & & & & \\
\hline Q4te & Eurylophalla epp. & EP & 3 & CG & of & & & & \\
\hline 651 & Heploponis cpp. & EP & 2.8 & sc & of & & & & \\
\hline $80 / 1$ & Alooephemera youngi & IEP & 2.1 & CG & of & & & & \\
\hline 871 & Prealoplophbobio Gep. & EPP & 1.2 & CG & of & & & & \\
\hline 88 & Strononems epp. & EPP & 3.4 & sc & of & & & & \\
\hline 69 & Tricorythodes app. & EP & 5.4 & CG & of & & & & \\
\hline 700 & Corydehe cornulass & ME & 5.6 & $\mathbf{P}$ & 0 & & & & \\
\hline $711 \mathrm{~B}$ & Noronia cerricornis & ME & 5.5 & $\mathbf{P}$ & of & & & & \\
\hline 725 & Stotie upp. & ME & 7.5 & & of & & & & \\
\hline 73 & Farikgia sp. & MG & 6.9 & Sc & 103.5 & & 4 & 2 & 8 \\
\hline 74 te & Boperis vinosa & TOD & 8.3 & $\mathbf{P}$ & a & & & & \\
\hline $751 \mathrm{c}$ & Conneotionides & 100 & 9 & $P$ & of & & & & \\
\hline $70 \mathrm{~B}$ & Pochydiplex bngipennin & 100 & 9.6 & $P$ & 9.6 & & 1 & & \\
\hline 77 & Acronourin ebnormis & IPL & 2.2 & $\mathbf{P}$ & of & & & & \\
\hline 78 & Acronourla eronoso & PL & 2.2 & $\mathbf{P}$ & of & & & & \\
\hline 790 & Acroneurio molo & $P$ PL & 0.9 & $P$ & of & & & & \\
\hline 000 & Acconouxle spo. & P2 & 1.4 & & of & & & & \\
\hline 811 & Aonatina epp. & $\mathrm{PL}$ & of & $\mathbf{P}$ & - & & & & \\
\hline $82 / 2$ & Alocspnia spp. & PL & 2.8 & $\mathbf{S H}$ & 0 & & & & \\
\hline 83 & Helopiaus sp. & $\frac{P L}{P L}$ & 0.4 & $\mathrm{P}$ & of & & & & \\
\hline BAfi & Iooperta epp. & $P L$ & & $\mathrm{P}$ & of & & & & \\
\hline 65) & Peroponting kensensis & PL & 2 & $P$ & a & & & & \\
\hline $86 \mathrm{P}$ & Peresontina spp. & P. & 2 & $P$ & of & & & & \\
\hline $87 \mathrm{~F}$ & Porbosts Epp. & PL. & 4.9 & $\mathbf{P}$ & - & & & & \\
\hline 89) & Pechinalla aphyre & IPL & of & $\mathbf{P}$ & of & & & & \\
\hline
\end{tabular}




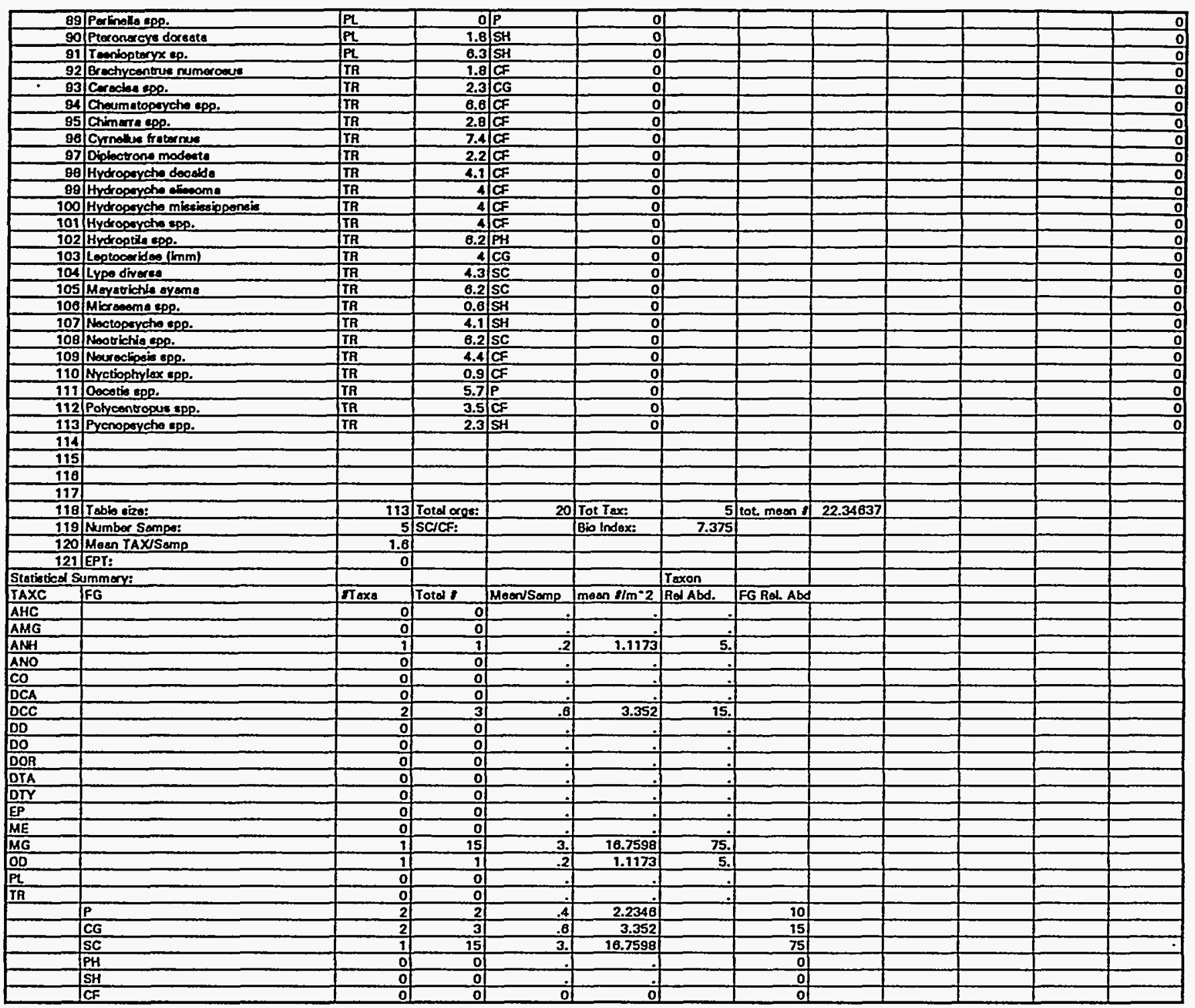


FMC RD C 08/20/93 STATION 15

Taxa List:

Hirudinea sp.

Chironomus spp.

Tribelos jucundum

Ferrissia sp.

Pachydiplax longipennis 


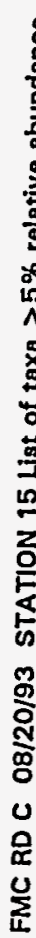

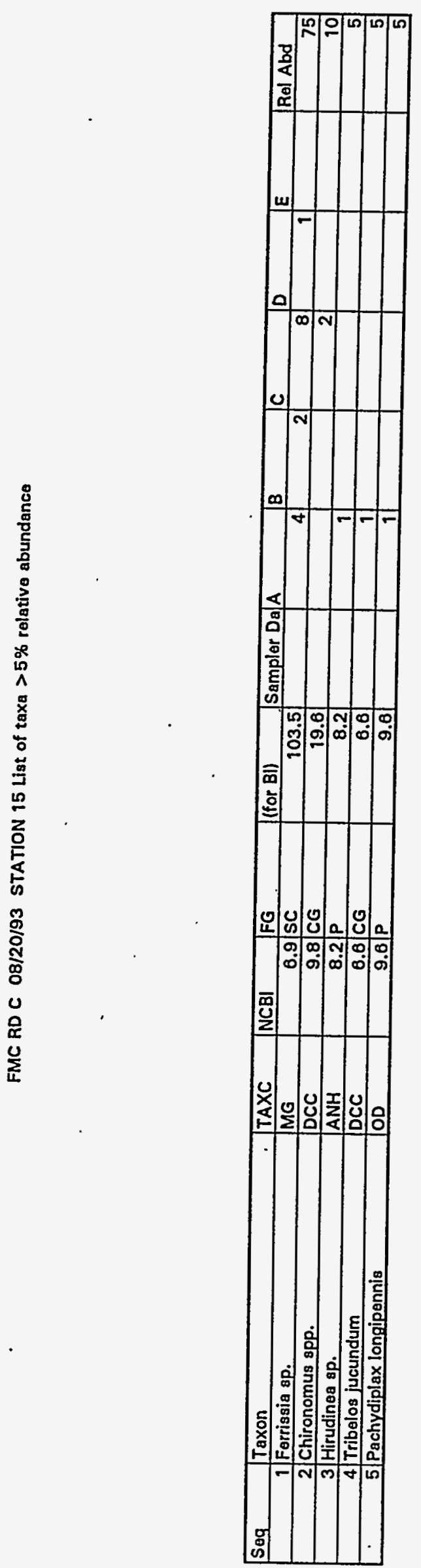

ن क्ष்:

要 


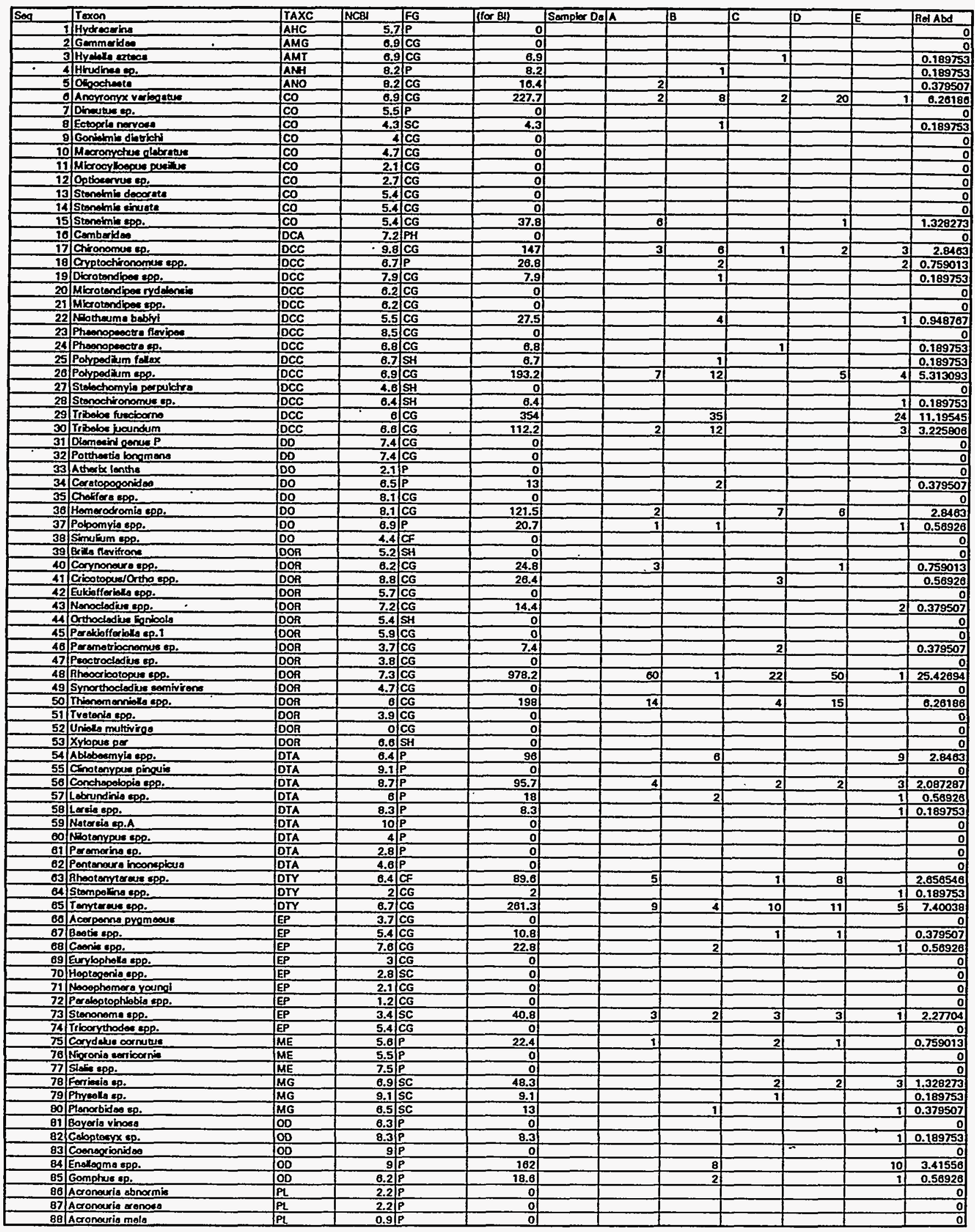




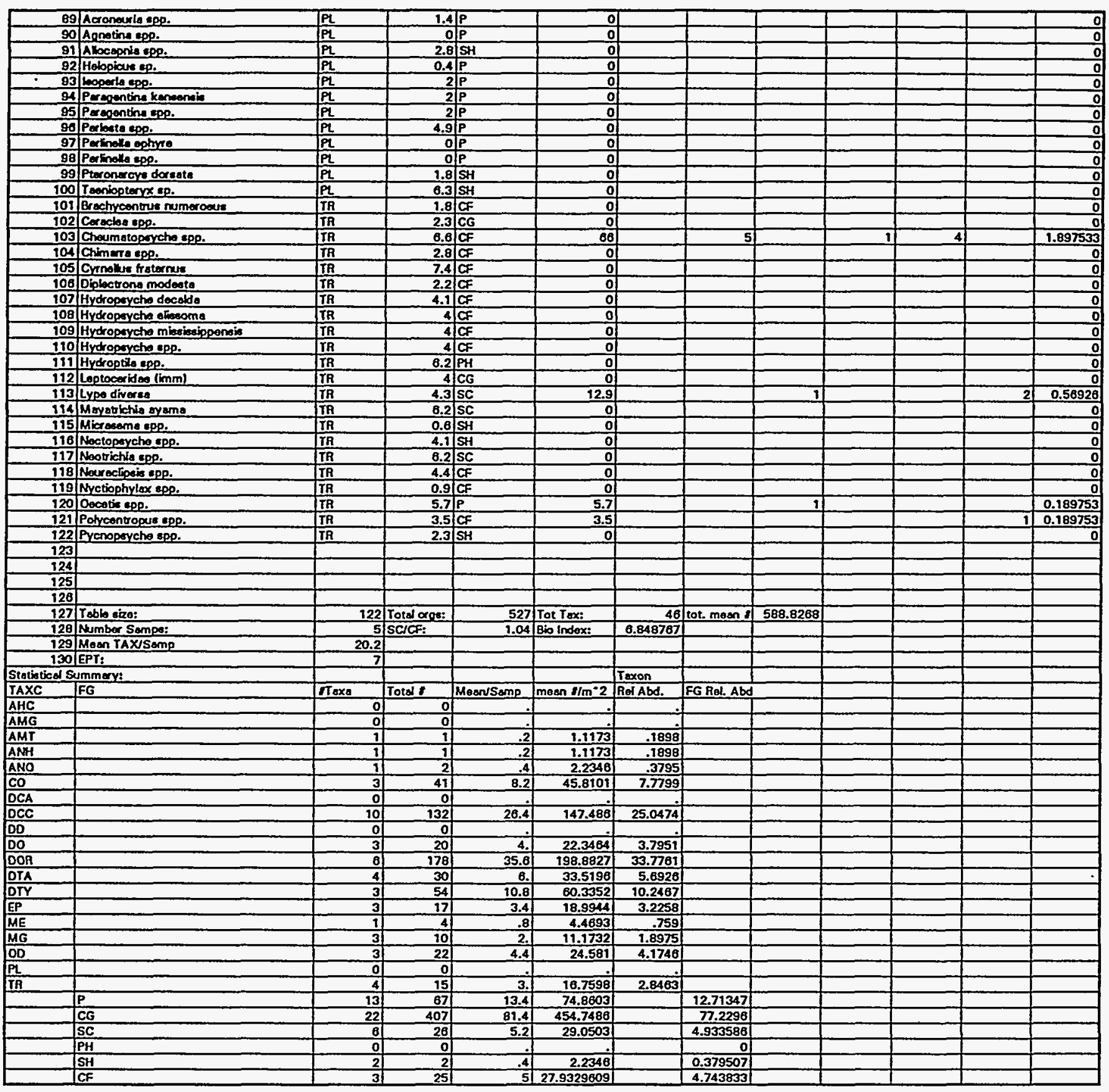


FMC RD - $4 \quad$ 08/20/93 STATION 16

\begin{tabular}{|l|}
\hline Taxa List: \\
\hline Hyalella azteca \\
\hline Hirudinea sp. \\
\hline Oligochaeta \\
\hline Ancyronyx variegatus \\
\hline Ectopria nervosa \\
\hline Stenelmis spp. \\
\hline Chironomus sp. \\
\hline Cryptochironomus spp. \\
\hline Dicrotendipes spp. \\
\hline Nilothauma babiyi \\
\hline Phaenopsectra sp. \\
\hline Polypedilum fallax \\
\hline Polypedilum spp. \\
\hline Stenochironomus sp. \\
\hline Tribelos fuscicorne \\
\hline Tribelos jucundum \\
\hline Ceratopogonidae \\
\hline Hemerodromia spp. \\
\hline Polpomyia spp. \\
\hline Corynoneura spp. \\
\hline Cricotopus/Ortho spp. \\
\hline Nanocladius spp. \\
\hline Parametriocnemus sp. \\
\hline Rheocricotopus spp. \\
\hline Thienemanniella spp. \\
\hline Ablabesmyia spp. \\
\hline Conchapelopia spp. \\
\hline Labrundinia spp. \\
\hline Larsia spp. \\
\hline Rheotanytarsus spp. \\
\hline Stempellina spp. \\
\hline Tanytarsus spp. \\
\hline Baetis spp. \\
\hline Caenis spp. \\
\hline Stenonema spp. \\
\hline Corydalus cornutus \\
\hline Ferrissia sp. \\
\hline Physella sp. \\
\hline Planorbidae sp. \\
\hline Caloptesyx sp. \\
\hline Enallagma spp. \\
\hline Gomphus sp. \\
\hline Cheumatopsyche spp. \\
\hline Oecetis spp. \\
\hline
\end{tabular}




\begin{tabular}{|c|c|c|c|c|c|c|c|c|c|c|c|c|}
\hline Seq & Taxon & TAXC & $\mathrm{NCBI}$ & FG & (for $\mathrm{BI})$ & Sampler Da & $\widehat{A}$ & B & C & D & $E$ & Rel Abd \\
\hline 1 & Rheocricotopus spp. & DOR & 7.3 & CG & 978.2 & & 80 & T & 22 & 50 & it & 25.42694 \\
\hline 2 & Tribelos fuscicorne & DCC & 6 & $\mathbf{C G}$ & 354 & & & 35 & & & 24 & 11.19545 \\
\hline 3 & Tanytarsus 8pp. & DTY & 6.7 & CG & 261.3 & & 9 & 4 & 10 & 11 & 5 & 7.40038 \\
\hline 4 & Ancyronyx variegatus & $\mathrm{CO}$ & 6.9 & CG & 227.7 & & 2 & 8 & 2 & 20 & 1 & 6.26186 \\
\hline 5 & 5Tienemanniella spp. & DOR & 8 & CG & 198 & & 14 & & 4 & 15 & & 6.26186 \\
\hline & Polypodilum 8pp. & DCC & 6.9 & CG & 193.2 & & 7 & 12 & & 5 & 4 & 5.313093 \\
\hline
\end{tabular}




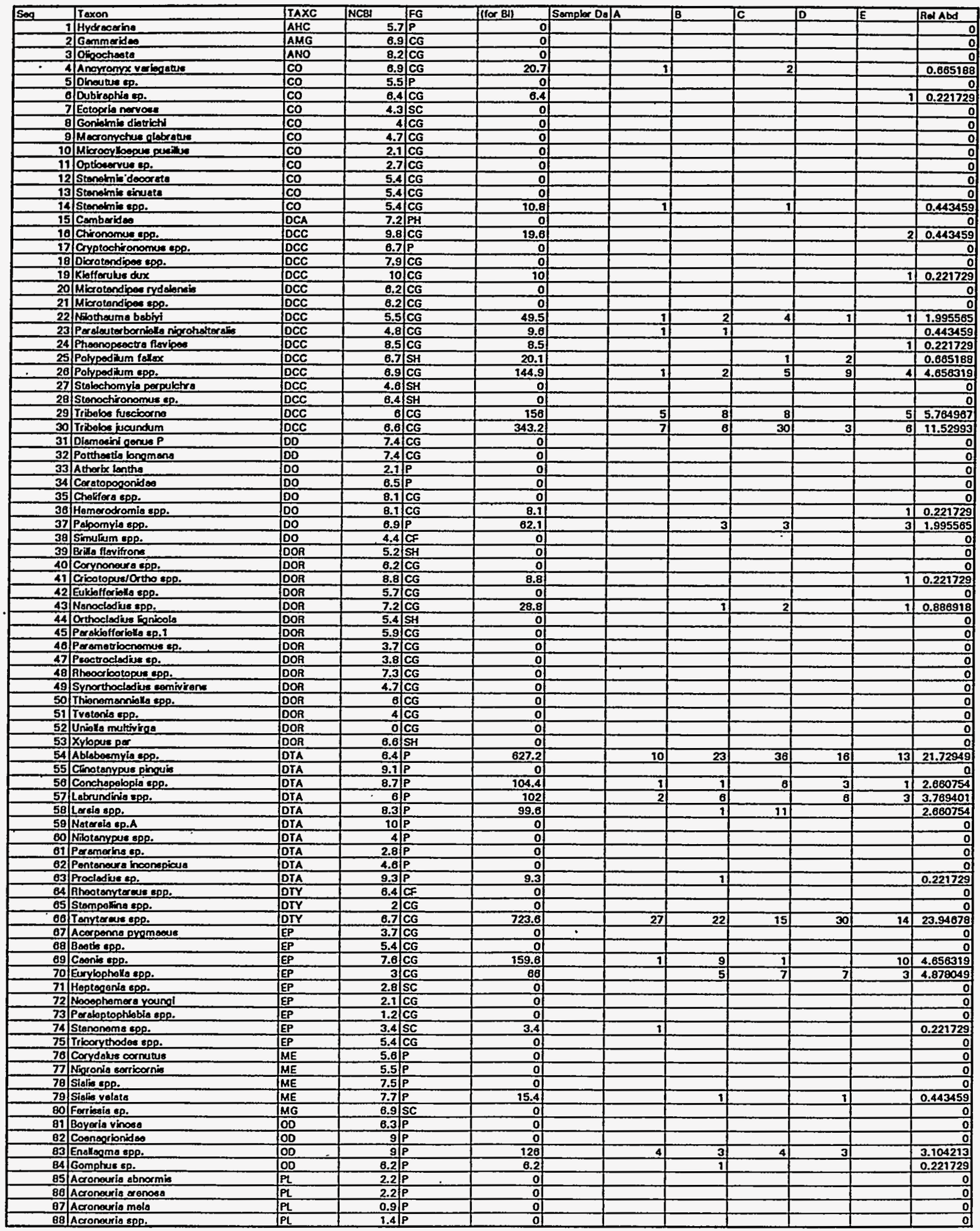




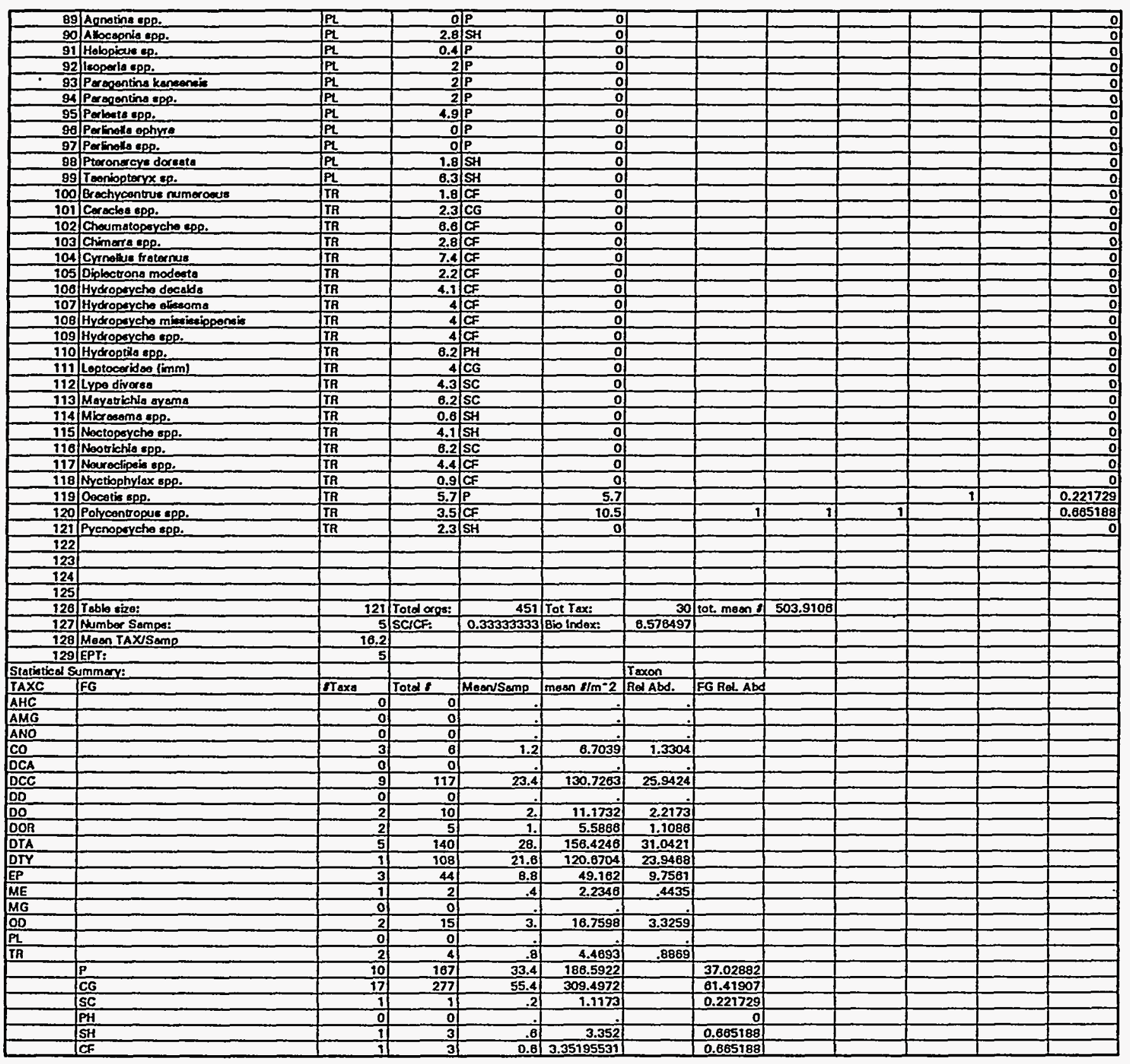


Taxa List:

Ancyronyx variegatus

Dubiraphia sp.

Stenelmis spp.

Chironomus spp.

Kiefferulus dux

Nilothauma babiyi

Paralauterborniella nigrohalteralis

Phaenopsectra flavipes

Polypedilum fallax

Polypedilum spp.

Tribelos fuscicorne

Tribelos jucundum

Hemerodromia spp.

Palpomyia spp.

Cricotopus/Ortho spp.

Nanocladius spp.

Ablabesmyia spp.

Conchapelopia spp.

Labrundinia spp.

Larsia spp.

Procladius sp.

Tanytarsus spp.

Caenis spp.

Eurylophella spp.

Stenonema spp.

Sialis velata

Enallagma spp.

Gomphus sp.

Oecetis spp.

Polycentropus spp. 


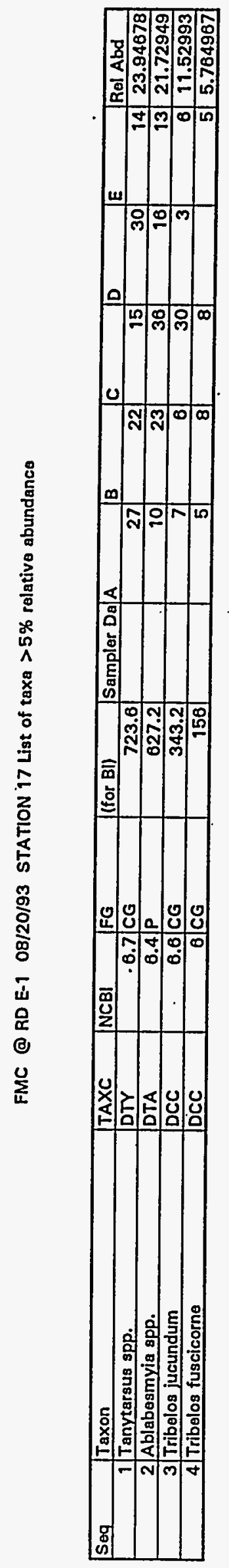




\begin{tabular}{|c|c|c|c|c|c|c|c|c|c|}
\hline Seq & Texon & $\operatorname{TAXC}$ & NCBI & FG & (for 8 in) & Sempler Da & A & 18 & C \\
\hline 1 & Hydrecerins & AHC & 5.7 & $P$ & 5.7 & & & II & \\
\hline 2 & Gemminidos & AMG & 8.9 & $\overline{C G}$ & of & & & & \\
\hline 3 & Origecthoste & ANO & 8.2 & $\overline{C G}$ & of & & & & \\
\hline$\div$ & Anorromp veriggetere & $\mathrm{CO}$ & 8.9 & CG & of & & & & \\
\hline 5 & Dincubue sp. & $\mathrm{Co}$ & 5.5 & P & 요 & & & & \\
\hline 6 & Ectopris nervoes & Co & 4.3 & sc & 4.3 & & & 1 & \\
\hline 7 & Gonialmin diaurchis & $\mathrm{Co}$ & 4 & CG & of & & & & \\
\hline 8 & Meromychus olobretere & $\mathrm{Co}$ & 4.7 & $\mathrm{CG}$ & 150.4 & & 7 & 3 & 6 \\
\hline 9 & Microorloeper puetis: & Co & 2.1 & CG & of & & & & \\
\hline 10 & Optionervus ep. & co & 2.7 & CG & - & & & & \\
\hline 11 & Stencinis decorate & Co & 5.4 & CG & of & & & & \\
\hline 12 & Stoneimis cinuete & $\mathrm{CO}$ & 5.4 & CG & 0 & & & & \\
\hline 13 & Stonahnie epp. & $\mathrm{Co}$ & 5.4 & CG & 59.4 & & 1 & & 2 \\
\hline 14 & Comberldes & DCA & 7.2 & $\mathrm{PH}$ & of & & 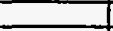 & & \\
\hline 15 & Cryptochironomue spa. & DCC & 6.7 & $P$ & o & & & & \\
\hline 10 & Dicrotondlowe sop. & Jocc & 7.9 & CG & of & & & & \\
\hline 17 & Mlorotendipee ryd slonein & DCC & 6.2 & CG & 6.2 & & 1 & & \\
\hline 18 & Mlorotandioes spe. & DCC & 6.2 & CG & of & & & & \\
\hline 19 & Notheums babiy & DOCC & 5.5 & CG & of & & & & \\
\hline 20 & Pheonopeoct of flavioges & $\overline{D C C}$ & 8.5 & CG & of & & & & \\
\hline 21 & Pohyeditum follox & DCC & 8.7 & SH & 8.7 & & & 1 & \\
\hline 22 & Polypedrum epp. & DCC & 8.9 & CG & 303.6 & & 17 & 10 & 3) \\
\hline 23 & Stolochomyit perpuletra & DCC & 4.6 & SH & 23 & & 1 & & 3 \\
\hline 24 & Stenochironomue ip. & DCC & 6.4 & SH & of & & & & \\
\hline 25 & Tribolos jucundum & $D C C$ & 8.6 & CG & of & & & & \\
\hline 26 & Dianesind penue P & Do & 7.4 & CG & 0 & & & & \\
\hline 27 & Potthestia lonomena & DD & 7.4 & $\mathrm{CG}$ & 이 & & & & \\
\hline 28 & Atherix lantha & 100 & 2.1 & P & 2.1 & & 1 & & \\
\hline 29 & Ceratopogonides & DO & 6.5 & $\mathbf{P}$ & of & & & & \\
\hline 30 & Cholfora spe. & Do & 8.1 & CG & of & & & & \\
\hline 31 & Homerodromila cpe. & $D O$ & 8.1 & CG & 105.3 & & 6. & 3 & 2 \\
\hline 32 & Simutiom epp. & DO & 4.4 & $C F$ & 61.6 & & 9) & 2 & 1 \\
\hline 33 & Brila flevifions & DOR & 5.2 & SH & 0 & & & + & 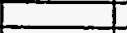 \\
\hline 34 & Corynomeure Egp. & DOR & 6.2. & CG & 18.6 & & 2 & II & \\
\hline 35 & Cricolopus/Ortho epp. & DOR & 8.8 & CG & 642.4 & & 2 & 10 & 37 \\
\hline 30 & Eukjalferiallo spp. & DOR & 5.7 & $C G$ & of & & & & \\
\hline 37 & Nonoclodive spp. & DOR & 7.2 & $\mathrm{CG}$ & 84.8 & & 2 & 2 & 4 \\
\hline 38 & Orthoclodiu: Exnicola & DOA & 5.4 & SH & o & & t & & \\
\hline 39 & Persiciafforialla ep.1 & DOA & 5.9 & CG & 5.9 & & & 1 & \\
\hline 40 & Peremetricenermus ep. & DOR & 3.7 & CG & 144.3 & & 22 & 5 & s) \\
\hline A1 & Peoctrocledive op. & DOR & 3.8 & CG & of & & & & 7 \\
\hline 42 & Aheocricotopuse spp. & DOR & 7.3 & $\mathbf{C G}$ & 423.4 & & 25 & 17 & 8 \\
\hline 43 & Synorthoctedive comivirens & DOA & 4.7 & CG & 4.7 & & 1 & & \\
\hline 44 & Thionemenniolo cpe. & DOA & 6 & CG & 390 & & 14 & 11) & 25 \\
\hline 45 & Trotonia epe. & DOR & 4 & CG & 40 & & 7 & 1 & 1 \\
\hline 46 & Unible muthiviros & DOR & of & CG & of & & & & 4 \\
\hline 47 & Xylopue par & DOA & 6.6 & SH & of & & & & \\
\hline 48 & Ableboemyio spg. & DTA & 6.4 & $P$ & of & & & & \\
\hline 49 & Cinotanypus pinquis & DTA & 9.1 & $P$ & of & & & & \\
\hline 50 & Conchspolopia spp. & DTA & 8.7 & $P$ & 104.4 & & 7 & 3 & 1) \\
\hline 51 & Lobrundinla epp. & DTA & 8 & $\mathbf{P}$ & 아 & & & & \\
\hline 52 & Naterela ep. A & DTA & 10 & $P$ & 0 & & & & \\
\hline 53 & NEotanypus epp. & DTA & 4 & $p$ & 16 & & 2 & & 2 \\
\hline 54 & Paramerina ep. & DTA - & 2.8 & $\mathbf{P}$ & of & & & & \\
\hline 55 & Pontencur a inoonspiaus & DTA & 4.8 & $P$ & 0 & & & & \\
\hline 56 & Rhoolenytareus cop. & DIY & 8.4 & $C F$ & 217.8 & & 13 & 5 & 12 \\
\hline 57) & Stompolins spp. & DIYY & 2 & CG & of & & & - & 7 \\
\hline 58 & Stompolinolite ap. & DTY & 5.3 & CG & 5.3 & & 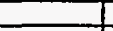 & - & 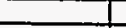 \\
\hline 59 & Tanytereciespo. & DTY & 8.7 & $\mathrm{CG}$ & 80.4 & & 6) & 3 & 3) \\
\hline 60 & A cerpenne pyemeous & EP & 3.7 & CG & a & & & $\pi$ & \\
\hline 61 & Bootie spp. & $E P$ & 5.4 & CG & 27 & & 1 & 3) & \\
\hline 62 & Coonis spp. & EP & 7.6 & CG & 7.0 & & 1 & & \\
\hline 63 & Ephomerallo sp. & EP & 1.4 & CG & 1.4 & & & & \\
\hline 64 & Eucylopholia epp. & EP & 3 & $\mathbf{C G}$ & 0 & & & & \\
\hline 65 & Heptegenie epp. & EP & 2.8 & sc & 16.8 & & & 3) & \\
\hline$\theta 8$ & Nooophamer a youmi & EP & 2.1 & CG & of & & & & \\
\hline 67 & Poroloptophwbis spp. & EP & 1.2 & $\mathrm{CG}$ & 0 & & & & \\
\hline 68 & Stononemo kpp. & $E P$ & 3.4 & SC & 23.8 & & 1 & 2 & 2 \\
\hline 69 & Iricorythodes ePp. & EP & 5.4 & CG & 0 & & & & -1 \\
\hline 70 & Pereponyx sp. & LEP & 5 & $\mathrm{PH}$ & 5 & & 1 & & \\
\hline 71 & Corrdelus cornutus & $M E$ & 5.6 & $\bar{P}$ & 5.6 & & & & 1 \\
\hline 72 & Noronis earricornis & $M E$ & 5.5 & $\mathbf{P}$ & 11 & & 11 & & 1 \\
\hline 73 & Sigin spg. & ME & 7.518 & $P$ & 0 & & & & \\
\hline 74 & Ferricalo ep. & MG & 6.9 & sc & 6.9 & & & 1 & \\
\hline 75 & Boyeria vinose & $O D$ & 6.3 & $\bar{P}$ & $-\quad$ of & & & & \\
\hline 78 & Coensocionides & 00 & 9 & $P$ & 0 & & & & Z \\
\hline 77 & Acronouris abnormis & $P L$ & 2.2 & $P$ & 35.2 & & 3 & 4 & 3 \\
\hline 78. & Acroneuria renose & $P L$ & 2.2 & $P$ & 요 & & & & $\square$ \\
\hline 79 & Acronouria mola & $\mathbf{P L}$ & 0.9 & $\mathbf{P}$ & - & & & & \\
\hline 80 & Acronemia spp. & $P L$ & 1.4 & $P$ & 으 & & & & \\
\hline 81 & Annotine spe. & $P L$ & of & $\mathbf{P}$ & 의 & & & & \\
\hline 82 & Alloceponia spp. & $P L$ & 2.8 & SH & of & & & & \\
\hline 83 & Holopicus ap. & $P L$ & 0.41 & $\mathbf{P}$ & of & & & & \\
\hline 84 & leoperla spp. & PL & 21 & $P$ & of & & & & \\
\hline 85 & Progentino konsonsis & $P L$ & 21 & $P$ & 10 & & 1 & & 2 \\
\hline 86. & Porepontine epp. & $P L$ & 21 & $\mathbf{P}$ & of & & & & \\
\hline B7 & Perbosto app. & $P L$ & 4.91 & $\mathrm{P}$ & of & & & & \\
\hline 8日 & Porlinalls aphyro & PL & of & $\mathbf{P}$ & of & & & & \\
\hline
\end{tabular}




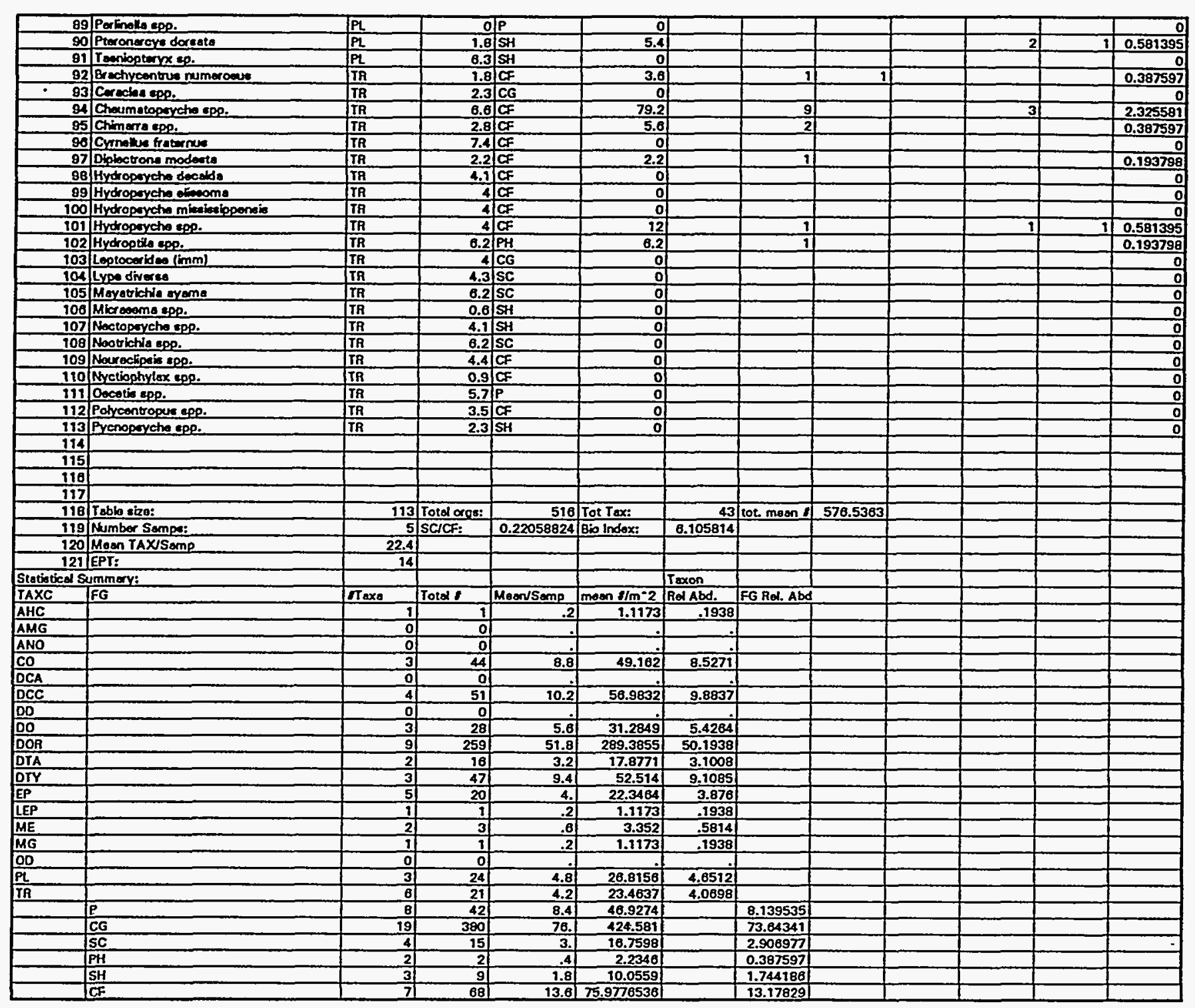




\section{UTR RD A 08/19/93 STATION 18}

\begin{tabular}{|l|}
\hline Taxa List: \\
\hline Hydracarina \\
\hline Ectopria nervosa \\
\hline Macronychus glabratus \\
\hline Stenelmis spp. \\
\hline Microtendipes rydalensis \\
\hline Polypedilum fallax \\
\hline Polypedilum spp. \\
\hline Stelechomyia perpulchra \\
\hline Atherix lantha \\
\hline Hemerodromia spp. \\
\hline Simulium spp. \\
\hline Corynoneura spp. \\
\hline Cricotopus/Ortho spp. \\
\hline Nanocladius spp. \\
\hline Parakiefferiella sp.1 \\
\hline Parametriocnemus sp. \\
\hline Rheocricotopus spp. \\
\hline Synorthocladius semivirens \\
\hline Thienemanniella spp. \\
\hline Tvetenia spp. \\
\hline Conchapelopia spp. \\
\hline Nilotanypus spp. \\
\hline Rheotanytarsus spp. \\
\hline Stempellinella sp. \\
\hline Tanytarsus spp. \\
\hline Baetis spp. \\
\hline Caenis spp. \\
\hline Ephemerella sp. \\
\hline Heptagenia spp. \\
\hline Stenonema spp. \\
\hline Paraponyx sp. \\
\hline Corydalus cornutus \\
\hline Nigronia serricornis \\
\hline Ferrissia sp. \\
\hline Acroneuria abnormis \\
\hline Paragentina kansensis \\
\hline Pteronarcys dorsata \\
\hline Brachycentrus numerosus \\
\hline Cheumatopsyche spp. \\
\hline Chimarra spp. \\
\hline Diplectrona modesta \\
\hline Hydropsyche spp. \\
\hline Hydroptila spp. \\
\hline
\end{tabular}


UTR RD A 08/19/93 STATION 18 List of taxa $>5 \%$ rolative abundence

\begin{tabular}{|c|c|c|c|c|c|c|c|c|c|c|c|c|}
\hline Seq & Taxon & TAXC & NCBI & FG & (for Bl) & Sampler Da & A & B & C & D & $E$ & Rel Abd \\
\hline 1 & Cricotopus/Ortho spp. & DOR & 8.8 & CG & 842.4 & & 2 & 10 & 37 & 23 & 1 & 14.14729 \\
\hline 2 & Thienemanniella spp. & DOR & $\underline{6}$ & CG & 390 & & 14 & 11) & 25 & 14 & 1) & 12.5969 \\
\hline 3 & Rheocricotopus spp. & DOR & 7.3 & CG & 423.4 & & 25 & 17) & 8 & 8 & & 11.24031 \\
\hline 4 & Polypodilum spp. & DCC & 8.9 & CG & 303.6 & & 17 & 10 & 3 & 14 & & 8.527132 \\
\hline 5 & Parametriocnemus sp. & DOR & 3.7 & CG & 144.3 & & 22 & 5 & 5 & 7 & & 7.55814 \\
\hline 6 & Rheotanytarsus spp. & DTY & 6.4 & CF & 217.6 & & 13 & 5 & 12 & 3 & 1 & 8.589147 \\
\hline & Macronychus glabratus & $\mathrm{CO}$ & 4.7 & CG & 150.4 & & 7 & 3 & 6 & 7 & 9] & 6.20155 \\
\hline
\end{tabular}




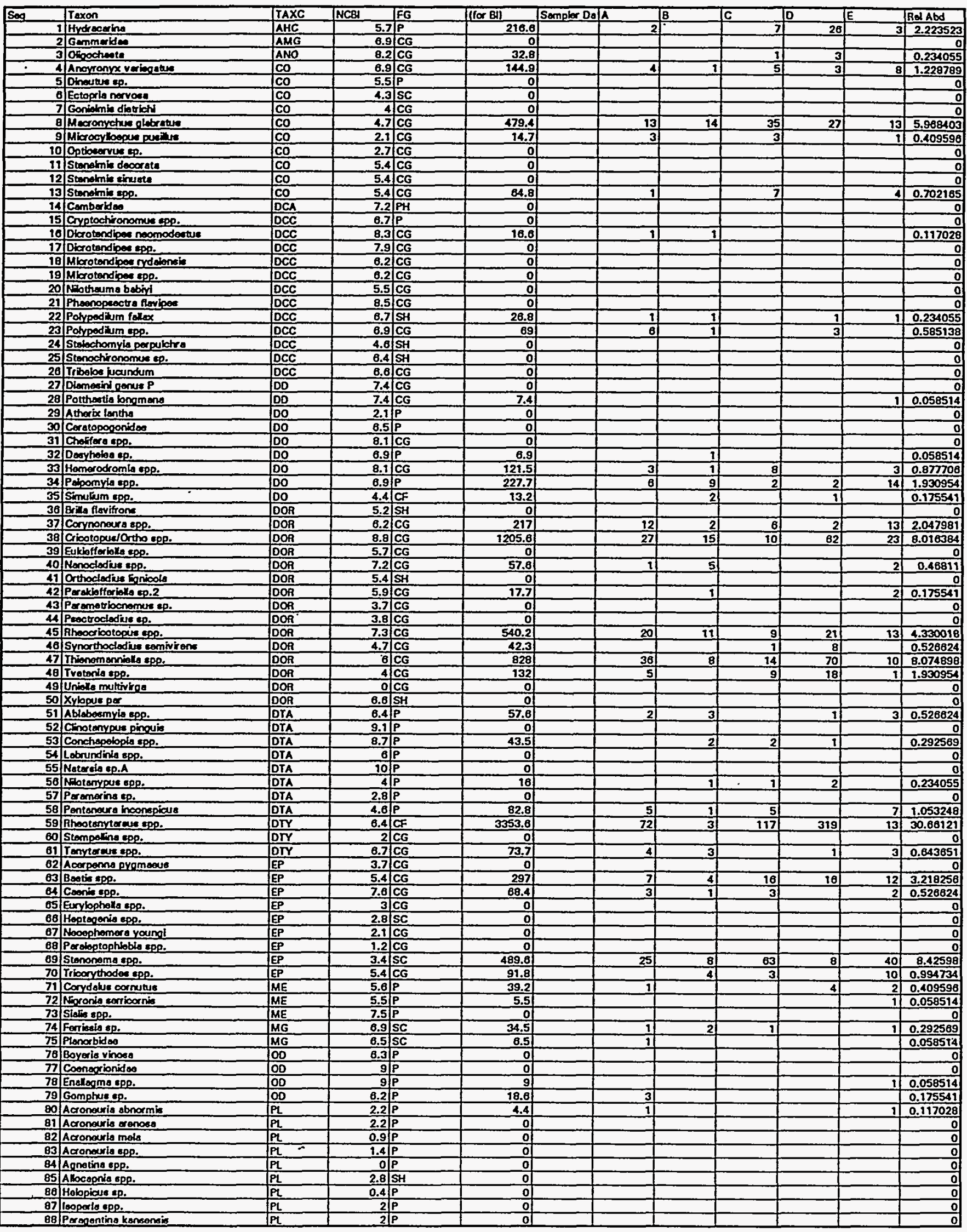




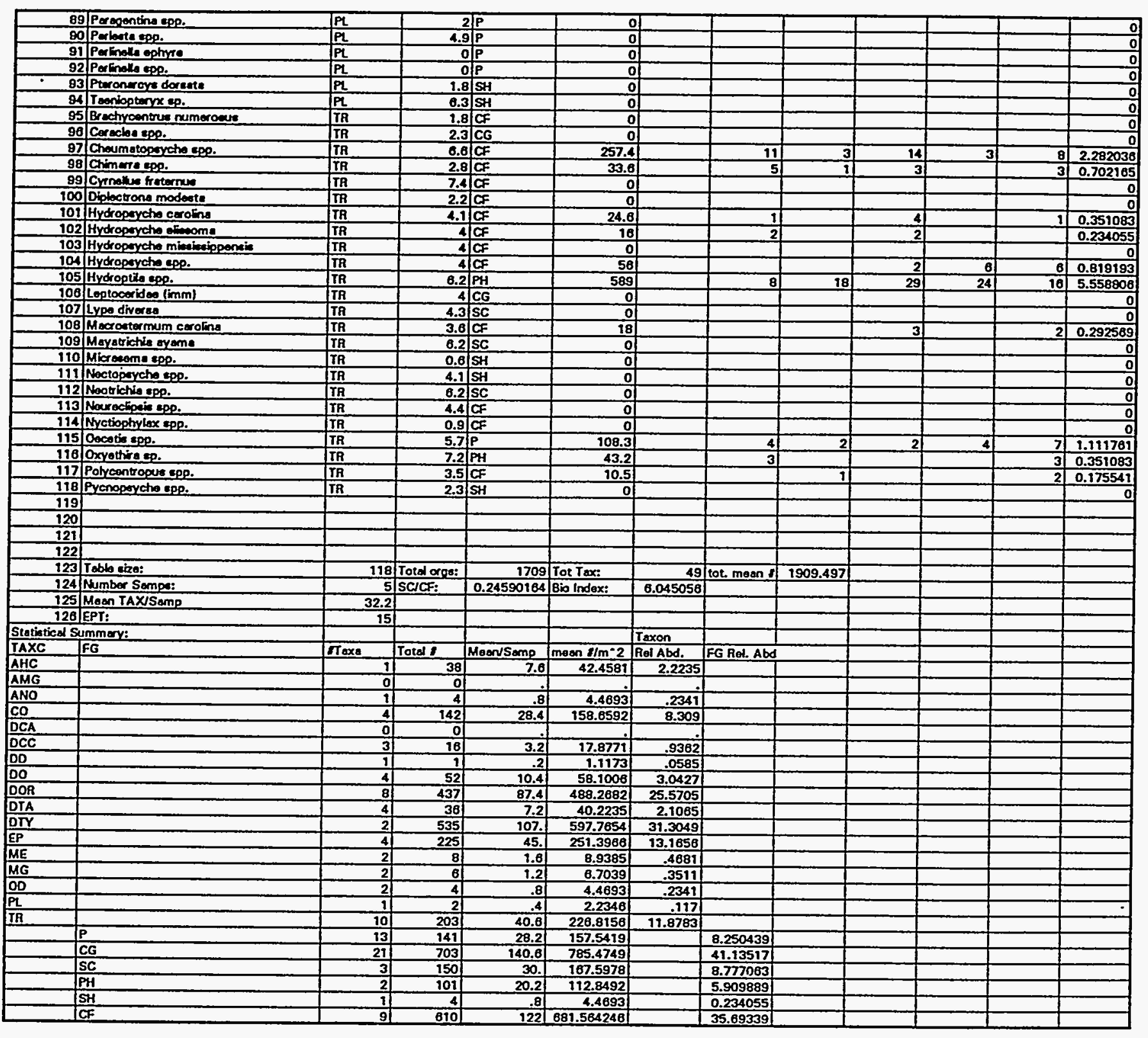


FMC RD A-7 08/20/93 STATION 19.

\begin{tabular}{|l|}
\hline Taxa List: \\
\hline Hydracarina \\
\hline Oligochaeta \\
\hline Ancyronyx variegatus \\
\hline Macronychus glabratus \\
\hline Microcylloepus pusillus \\
\hline Stenelmis spp. \\
\hline Dicrotendipes neomodestus \\
\hline Polypedilum fallax \\
\hline Polypedilum spp. \\
\hline Potthastia longmana \\
\hline Dasyhelea sp. \\
\hline Hemerodromia spp. \\
\hline Paipomyia spp. \\
\hline Simulium spp. \\
\hline Corynoneura spp. \\
\hline Cricotopus/Ortho spp. \\
\hline Nanocladius spp. \\
\hline Parakiefferiella sp.2 \\
\hline Rheocricotopus spp. \\
\hline Synorthocladius semivirens \\
\hline Thienemanniella spp. \\
\hline Tvetenia spp. \\
\hline Ablabesmyia spp. \\
\hline Conchapelopia spp. \\
\hline Nilotanypus spp. \\
\hline Pentaneura inconspicua \\
\hline Rheotanytarsus spp. \\
\hline Tanytarsus spp. \\
\hline Baetis spp. \\
\hline Caenis spp. \\
\hline Stenonema spp. \\
\hline Tricorythodes spp. \\
\hline Corydalus cornutus \\
\hline Nigronia serricornis \\
\hline Ferrissia sp. \\
\hline Planorbidae \\
\hline Enallagma spp. \\
\hline Gomphus sp. \\
\hline Acroneuria abnormis \\
\hline Cheumatopsyche spp. \\
\hline Chimarra spp. \\
\hline Hydropsyche carolina \\
\hline Hydropsyche elissoma \\
\hline Hydropsyche spp. \\
\hline Mydroptila spp. \\
\hline Oecrostis spp. \\
\hline Oxyethira sp. \\
\hline
\end{tabular}


Polycentropus spp. 


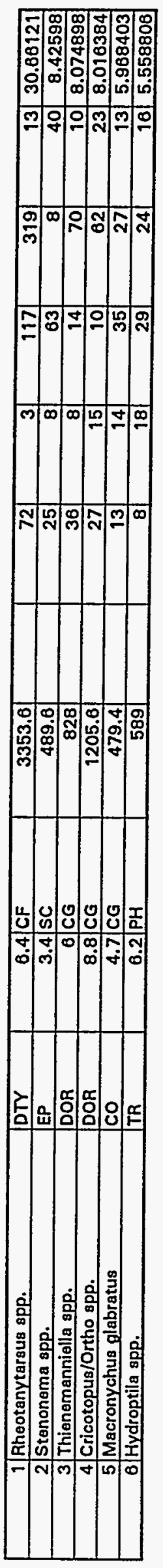




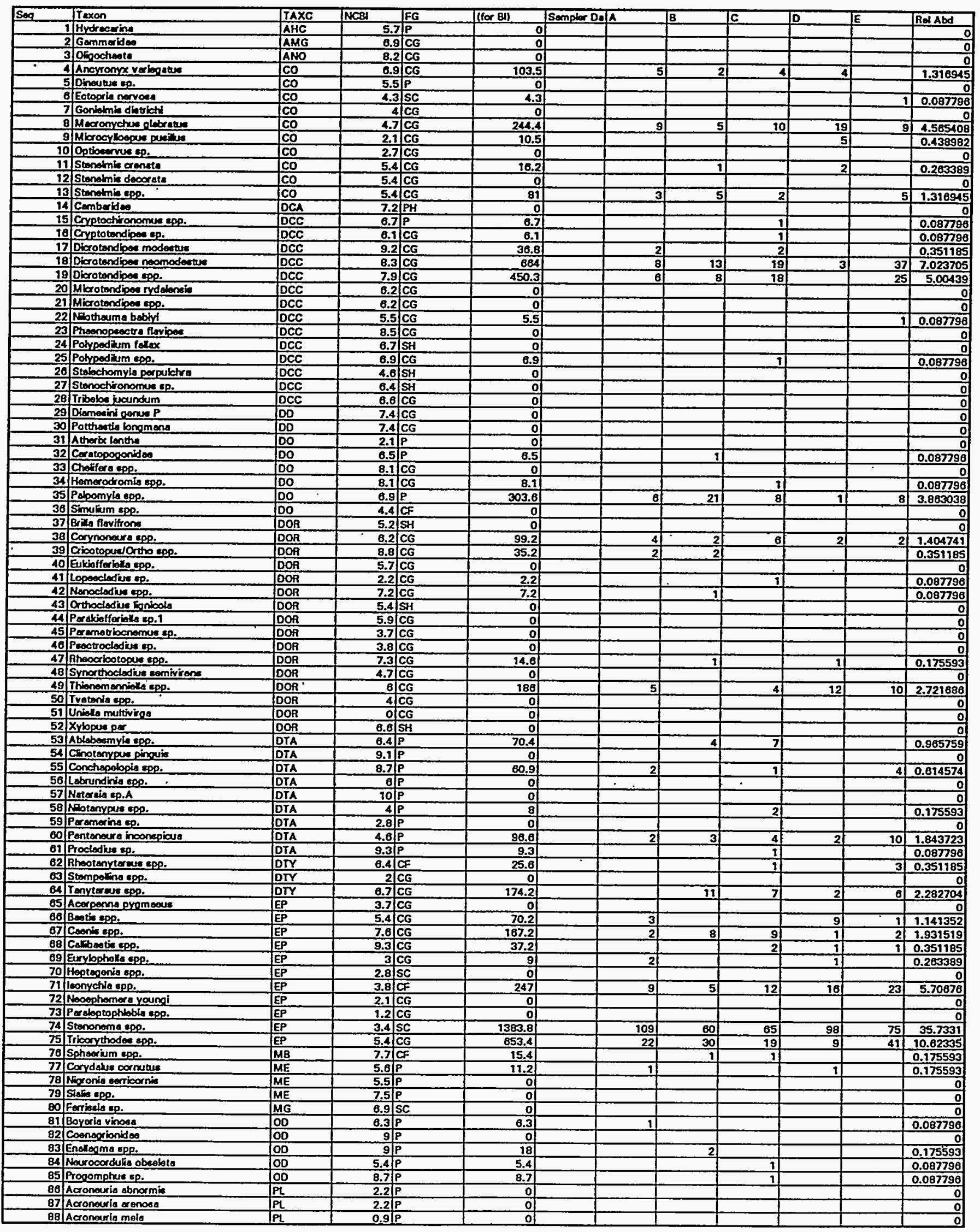




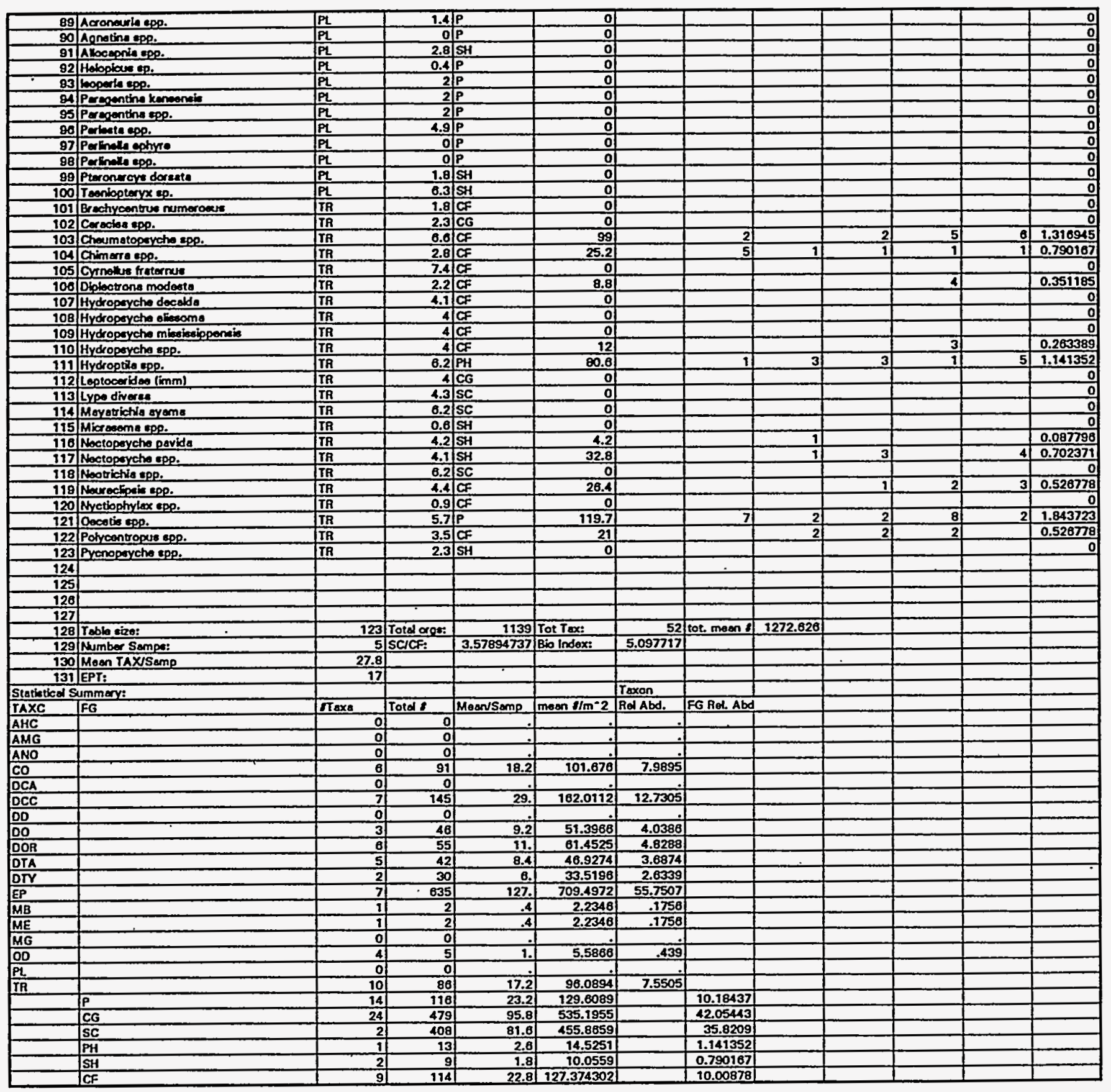




\begin{tabular}{|l|}
\hline Taxa List: \\
\hline Ancyronyx variegatus \\
\hline Ectopria nervosa \\
\hline Macronychus glabratus \\
\hline Microcylloepus pusillus \\
\hline Stenelmis crenata \\
\hline Stenelmis spp. \\
\hline Cryptochironomus spp. \\
\hline Cryptotendipes sp. \\
\hline Dicrotendipes modestus \\
\hline Dicrotendipes neomodestus \\
\hline Dicrotendipes spp. \\
\hline Nilothauma babiyi \\
\hline Polypedilum spp. \\
\hline Ceratopogonidae \\
\hline Hemerodromia spp. \\
\hline Palpomyia spp. \\
\hline Corynoneura spp. \\
\hline Cricotopus/Ortho spp. \\
\hline Lopescladius sp. \\
\hline Nanocladius spp. \\
\hline Rheocricotopus spp. \\
\hline Thienemanniella spp. \\
\hline Ablabesmyia spp. \\
\hline Conchapelopia spp. \\
\hline Nilotanypus spp. \\
\hline Pentaneura inconspicua \\
\hline Procladius sp. \\
\hline Rheotanytarsus spp. \\
\hline Tanytarsus spp. \\
\hline Baetis spp. \\
\hline Caenis spp. \\
\hline Callibaetis spp. \\
\hline Eurylophella spp. \\
\hline Isonychia spp. \\
\hline Stenonema spp. \\
\hline Tricorythodes spp. \\
\hline Sphaerium spp. \\
\hline Corydalus cornutus \\
\hline Boyeria vinosa \\
\hline Enallagma spp. \\
\hline Neurocordulia obseleta \\
\hline Progomphus sp. \\
\hline Cheumatopsyche spp. \\
\hline Chimarra spp. \\
\hline Hectopstropsyche spp. \\
\hline
\end{tabular}


FMC-A-13.2 08/20/93 STATION 20

Nectopsyche spp.

Neureclipsis spp.

Oécetis spp.

Polycentropus spp. 


\begin{tabular}{|c|c|c|c|c|c|c|c|c|c|c|c|c|}
\hline Seg & Taxon & TTAXC & $\mathrm{NCBI}$ & FG & (for Bl) & Sampler D & A & TB & JC & $\sqrt{D}$ & TE & Rel Abd \\
\hline 1 & Stenonema spp. & EP & 3.4 & sc & 1383.8 & & 109 & 60 & 65 & 98 & 75 & 35.7331 \\
\hline & Tricorythodes spp. & EEP & & CG & 0.53 .4 & & 22 & 30 & 19 & 9 & 41 & 10.62335 \\
\hline & Dicrotendipes neomodestus & DCC & 8.3 & CG & 864 & & 8 & 13 & 19 & 3 & 37 & 7.023705 \\
\hline 4 & Isonychia spp. & EP & 3.8 & $C F$ & 247 & & 9 & 5 & 12 & 16 & 23 & 5.70870 \\
\hline & Dicrotendipes spp & DCCC & & CG & 450.3 & & 8 & 8 & 18 & & 25 & 5.00439 \\
\hline
\end{tabular}




\begin{tabular}{|c|c|c|c|c|c|c|c|c|c|}
\hline $\operatorname{sen}$ & Taxan & TAXC & NCBI & FG & (lor Bin & Sornplex Da & $\mathbf{A}$ & B & C \\
\hline 1 & I Hydrecerine & AHC & 5.7 & $P$ & of & & & & \\
\hline 2 & 2 Gommeidso & AMG & 6.9 & CG & 0 & & & & \\
\hline 3 & Oropectresto & ANO & 8.2 & CG & 0 & & & & \\
\hline 4 & Ancromy veriegstus & Co & 6.9 & GG & of & & & & \\
\hline$\overline{\mathbf{5}}$ & 5 Dinculue ep. & Co & 5.5 & $\mathbf{P}$ & of & & & & \\
\hline a & Dubirephio co. & $\mathrm{Co}$ & 6.4 & CG & 0.4 & & & & \\
\hline 7 & Ecteprie nervose & co & 4.3 & SC & of & & & & \\
\hline 8 & Gonialnie diatrich & co & 4 & CG & of & & & & \\
\hline 9. & Mecronychus qlabratuse & Co & 4.7 & CG & of & & & & \\
\hline 10 & Mtcrooy loepue pusitus & $\mathrm{Co}$ & 2.1 & CG & of & & & & \\
\hline 11 & Optioearvua ap. & $\mathrm{Co}$ & 2.7 & CG & of & & & & \\
\hline 12 & 2) Stenoinis orentats & co & 5.4 & CG & 5.4 & & & & 1 \\
\hline 13 & Stoneimis epp. & co & 5.4 & CG & 16.2 & & & II & \\
\hline 14 & Camberides & DGA & 7.2 & $\mathrm{PH}$ & of & & & & \\
\hline 15 & Cryptochironomue epp. & DCC & 0.7 & $P$ & 0 & & & & \\
\hline 16 & Cryptotendipes ep. & DCC & 0.1 & CG & 0 & & & & \\
\hline 17 & Dicrotendipes modectus & DCC & 9.2 & $\overline{C G}$ & of & & & & \\
\hline 10 & Dierotendipos noomodectus & DOCC & 8.3 & CG & 8.3 & & 1 & & \\
\hline 19 & Dicrotondipes epp. & DCC & 7.9 & $\mathrm{CG}$ & 15.8 & & & 2 & \\
\hline 20 & Miorotondipes rydalonsis & DCC & 6.2 & CG & of & & & & \\
\hline 21 & Microtandipes epp. & DCC & 6.2 & CG & of & & & & \\
\hline 22 & Nilothouma bobiyi & DCCC & 5.5 & cG & 0 & & & & \\
\hline 23) & Pheonopecectra fiavipes & TDCC & 8.5 & CG & 0 & & & & \\
\hline 24 & Potypodilum fallox & TिCC & 6.7 & SH & of & & & & \\
\hline 25 & Pohypedium epp. & DCC & 6.9 & CG & 8.9 & & & & \\
\hline 26 & Stobochomyla perpuletro & DCC & 4.6 & SH & of & & & & \\
\hline 27. & Istanoctironomus ep. & DCC & 6.4 & SH & of & & & & \\
\hline 28 & Tribolos jucundum & DCC & 6.8 & CG & 0 & & & & \\
\hline 29 & Dlemesini penue $P$ & DO & 7.4 & CG & 0 & & & & \\
\hline 30 & Polthastia bonomens & $D$ & 7.4 & CG & o. & & & & \\
\hline 3i & Atherix lantho & 0 & 2.1 & $\mathbf{P}$ & of & & & & \\
\hline 32 & Coratopononidos & DoO & 6.5 & $\mathbf{P}$ & 32.5 & & & & 5! \\
\hline 33 & Chelfera epo. & DO & 8.11 & CG & of & & & & \\
\hline 34 & Ephydridos & DO & 6 & $\mathrm{PH}$ & 84 & & & 3 & j) \\
\hline 35 & Hemerodromie spp. & 00 & 8.1 & CG & 0 & & & & \\
\hline 38 & Palpomyia spp. & 100 & 6.9 & $\bar{P}$ & of & & & & \\
\hline 37 & Simuleum app. & Do & 4.4 & CF & o| & & & & \\
\hline 38 & Beile fiovifions & DOR & 5.2 & SH & of & & & & \\
\hline 39 & Corynoneura upp. & DOR & 6.2 & CG & of & & & & \\
\hline 40 & Criootopue/Ortho spp. & DOR & 8.8 & CG & 79.2 & & 2 & & 4 \\
\hline 41 & Eukiofferiots spp. & DOR & 5.7 & CG & 0 & & & & \\
\hline 42 & Loposcloditus ep. & DOR & 2.2 & CG & o| & & & & \\
\hline 43 & Nanocledive upp. & DOA & 7.2 & CG & o. & & & & \\
\hline 44 & Orthoclodius Eonicole & DOA & 5.4 & SH: & of & & & & \\
\hline 45 & Perakjolferiallo sp.1 & DOR & 5.9 & CG & of & & & & \\
\hline 46 & Premetriocnamus ep. & DOR & 3.7 & CG & ol & & & & \\
\hline 47 & Peoctrocladiue ep. & DOA & 3.8 & CG & 0 & & & & \\
\hline 48 & Rheocticotopus spp. & DOA & 7.3 & CG & o & & & & \\
\hline 48 & Synorthocledivs semivirens & DOR & 4.7 & CG & of & & & & \\
\hline 50 & Thionomennidly spp. & DOR & 6 & CG & 6) & & & & \\
\hline 51 & Tretenla epp. & DOR & 4 & CG & 12 & & & & \\
\hline 52 & Uniols multivirga & DOR & olc & CG & 0 & & & & \\
\hline 53. & Xylopueper & DOR & 6.6 & SH & - & & & & \\
\hline 54 & Ablabosmyia spp. & DTA & 6.48 & $\bar{p}$ & 172.8 & & 3 & 3) & 12 \\
\hline 55 & Crnotenypus pinouis & DIA & $9.1 \mathrm{~F}$ & $\mathbf{P}$ & 0 & & & 4 & \\
\hline 58 & Conchapolopio spp. & Dra & 8.7 & $\mathbf{P}$ & 26.1 & & 2 & & - \\
\hline 57 & Labrundinia spp. & DTA & 6) & $\mathbf{P}$ & 0 & & & & \\
\hline 58 & Notereis Gp.A & DIA & 1018 & $P$ & of & & & & \\
\hline 58 & Nitotenypus epp. & DTA & $4 \mid \mathrm{F}$ & $\mathbf{P}$ & of & & & & \\
\hline 60 & Peramerina co. & DTA & $2.8 \mid F$ & $\mathbf{P}$ & 可 & & & & \\
\hline 61 & Pentanours inconepiara & DTA & $4.8 / \mathrm{F}$ & $\mathbf{P}$ & 98.6 & & 3 & 6) & 5 \\
\hline 62 & Procladive sp. & DTA & $9.3 \mathrm{P}$ & $\mathbf{P}$ & 0 & & & & \\
\hline 63 & fihootenytareus spp. & DTY & $6.4 \bar{C}$ & CF & 38.4 & & it & & I) \\
\hline a4 & Stompeling spg. & OTY & 20 & $\overline{\text { CG }}$ & of & & & & \\
\hline 65 & Tanyteraie spp. & OTY & $6.7 \mid \mathrm{c}$ & CG & 8.7 & & & & \\
\hline 68 & Acorpenna pyombove & EP & $3.7 \mathrm{C}$ & CG & 0 & & & & \\
\hline 67 & Beotin spp. & EP & 5.45 & CG & 59.4 & & 2 & & 4 \\
\hline 68 & Coonis epp. & EP & 7.6 & CG & 53.2 & & 3) & 2 & 1 \\
\hline 69 & Collbeotis app. & EP & $9.3 \mathrm{C}$ & CG & of & & & & \\
\hline 70 & Eurylopholle spe. & EP & $31 \mathrm{c}$ & CG & ot & & & & \\
\hline 71 & Hoptoponia opp. & EP & 2.85 & SC & o| & & & & \\
\hline 72 & soonychia apg. & EP & $3.8 \mid \mathrm{C}$ & CF & 0 & & & & \\
\hline 73 & Nooephomere youngl & EP & 2.10 & CG & o. & & & & \\
\hline 74 & Poraloptophloble epp. & EP & $1.2 \mathrm{C}$ & CG & 0 & & & & \\
\hline 75 & Stennoma top. & EP & 3.45 & SC & 686.8 & & 44 & 29 & 80 \\
\hline 78 & Iricory thodes epp. & EP & $5.4 \sqrt{c}$ & CG & 129.6 & & 8 & 4 & 8 \\
\hline 77 & Pyiralid so (pupso) & LEP & 5 क & $\overline{P H}$ & 15 & & & & \\
\hline 78 & Sphsorium epp. & MB & $7.7 \mathrm{C}$ & $C F$ & of & & & & \\
\hline 79 & Corydalus cornuts: & ME & 5.618 & $P$ & 5.6 & & & & \\
\hline$\infty$ & Nigronia cerricornis & ME & $5.5] \mathrm{P}$ & $\mathbf{P}$ & $0 \mid$ & & & & \\
\hline 81 & Stolis spp. & ME & $7.5 \mid \mathrm{P}$ & $\mathbf{P}$ & 0 & & & & \\
\hline 62 & Forricsia sp. & MG & 6.95 & SC & 20.7 & & 1 & & 1 \\
\hline 83 & Hydrobîd 00 & MG & 6.55 & SC & 884 & & 28 & 27 & 30 \\
\hline 84 & Phyealls spp. & MG & $9.1 \mathrm{~s}$ & SC & 127.4 & & c & 3 & 2 \\
\hline 85 & Pienorbid os & MG & $6.5 \mathrm{~s}$ & SC & 591.5 & & 7) & 27 & 10 \\
\hline 86 & Argia ep. & 100 & $8.71 P$ & $P$ & 8.7 & & & & \\
\hline 87 & Boyerla vinosa & 100 & $6.31 P$ & $P$ & 6.3 & & & & \\
\hline 88 & Coenenrionidea & 100 & 9 & $P$ & o. & & & & \\
\hline
\end{tabular}




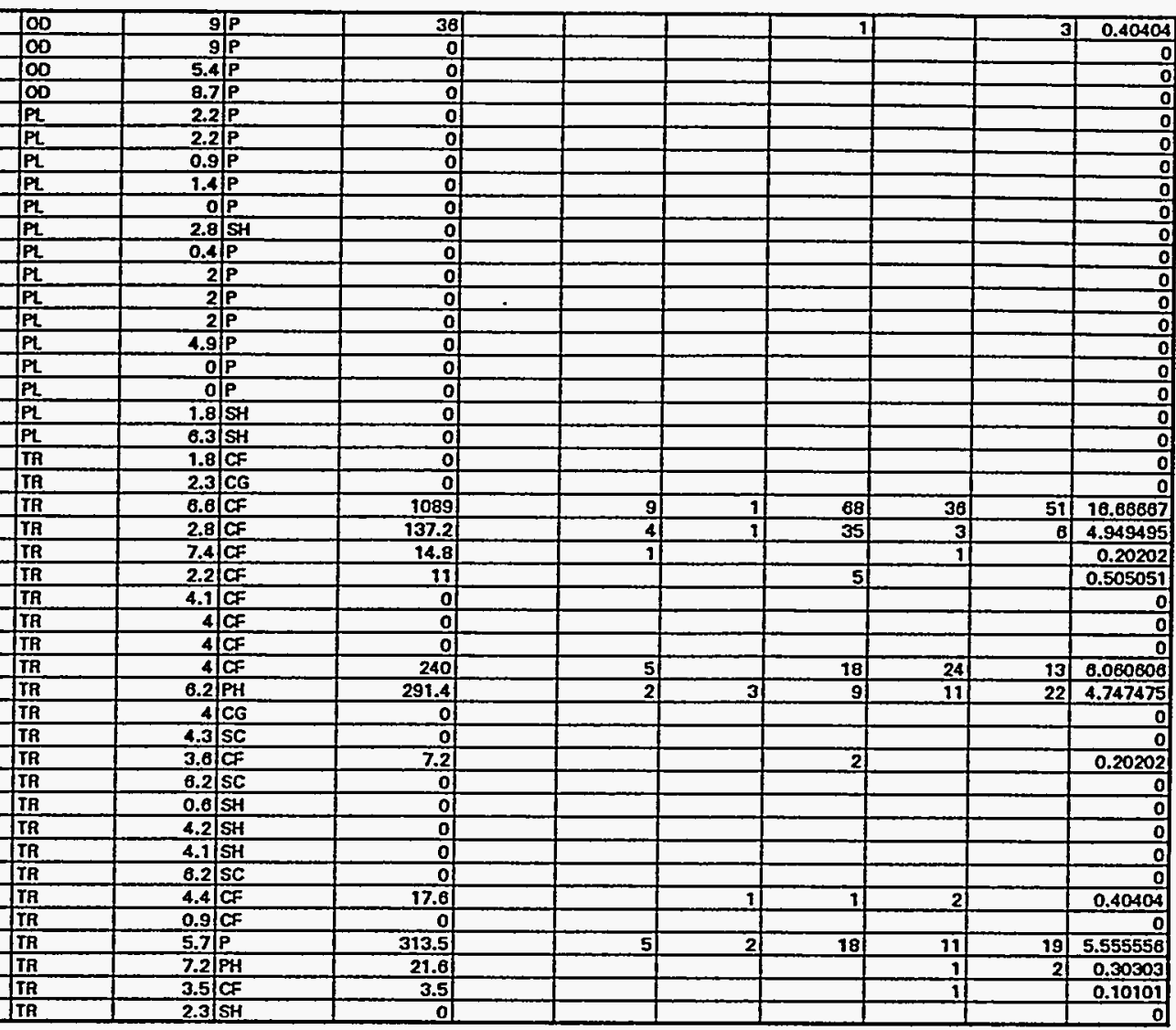




\begin{tabular}{|l|}
\hline Taxa List: \\
\hline Dubiraphia sp. \\
\hline Stenelmis crenata \\
\hline Stenelmis spp. \\
\hline Dicrotendipes neomodestus \\
\hline Dicrotendipes spp. \\
\hline Polypedilum spp. \\
\hline Ceratopogonidae \\
\hline Ephydridae \\
\hline Cricotopus/Ortho spp. \\
\hline Thienemanniella spp. \\
\hline Tvetenia spp. \\
\hline Ablabesmyia spp. \\
\hline Conchapelopia spp. \\
\hline Pentaneura inconspicua \\
\hline Rheotanytarsus spp. \\
\hline Tanytarsus spp. \\
\hline Baetis spp. \\
\hline Caenis spp. \\
\hline Stenonema spp. \\
\hline Tricorythodes spp. \\
\hline Pyralidae (pupael \\
\hline Corydalus cornutus \\
\hline Ferrissia sp. \\
\hline Hydrobiidae \\
\hline Physella spp. \\
\hline Planorbidae \\
\hline Argia sp. \\
\hline Boyeria vinosa \\
\hline Enallagma sp. \\
\hline Cheumatopsyche spp. \\
\hline Chimarra spp. \\
\hline Cyrnellus fraternus \\
\hline Diplectrona modesta \\
\hline Hydropsyche spp. \\
\hline Hydroptila spp. \\
\hline Macrostemum carolina \\
\hline Neureclipsis spp. \\
\hline Oecetis spp. \\
\hline Oxyethira spp. \\
\hline Polycentropus spp. \\
\hline
\end{tabular}


INDIAN GRAVE BRANCH @ RD B 088/19/93 STATION 21 List of taxa >5\% relative abundance

\begin{tabular}{|c|c|c|c|c|c|c|c|c|c|c|c|}
\hline Seq & Taxon & TAXC & NCB & FG & (for $\mathrm{Bl})$ & \begin{tabular}{|l|l|} 
Sampler Da|A \\
\end{tabular} & B & c & $D$ & $E$ & Rel Abd \\
\hline 1 & Stenonema spp. & EP & 3.4 & Sc & 688.8 & 44 & 29 & 80 & 21 & 28) & 20.40404 \\
\hline 2 & Cheumatopsyche spp. & TR & 6.6 & CF & 1089 & 9 & 1 & 68 & 38 & 51 & 16.66667 \\
\hline 3 & Hydrobiidae & MG & 6.5 & SC & 884 & 26 & 27 & 30 & 21 & 32 & 13.73737 \\
\hline 4 & Planorbidae & MG & Q.5 & SC & 591.5 & $\overline{7}$ & 27 & 10 & 13 & 34 & 9.191919 \\
\hline 5 & Hydropsyche spp. & TR & & CF & 240 & 5 & & 18 & 24 & 13 & 6.080806 \\
\hline B) & Oecetis spp. & TR & 5.7 & & 313.5 & 5 & 2 & 18 & 11 & 19 & 5.555556 \\
\hline
\end{tabular}




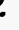

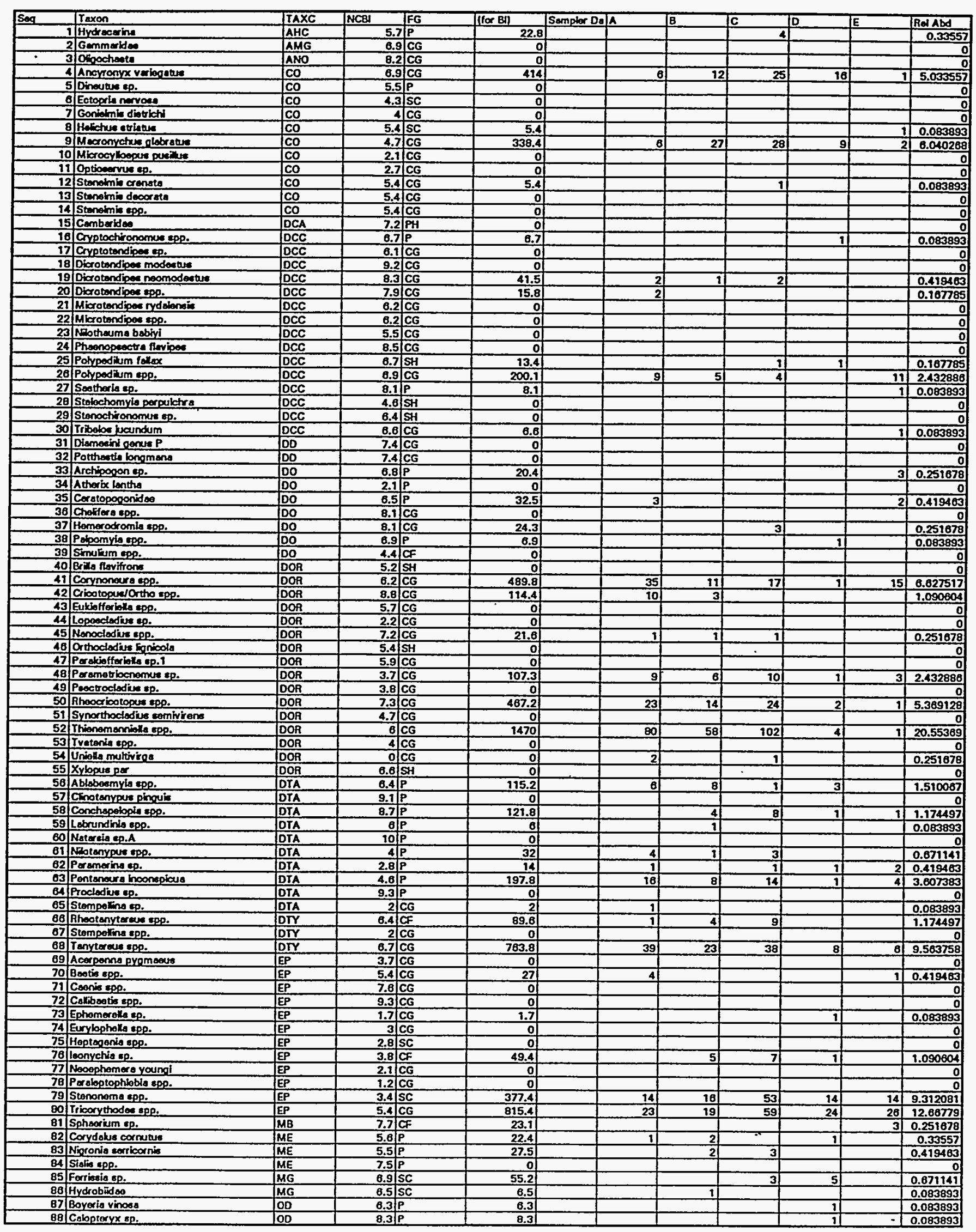




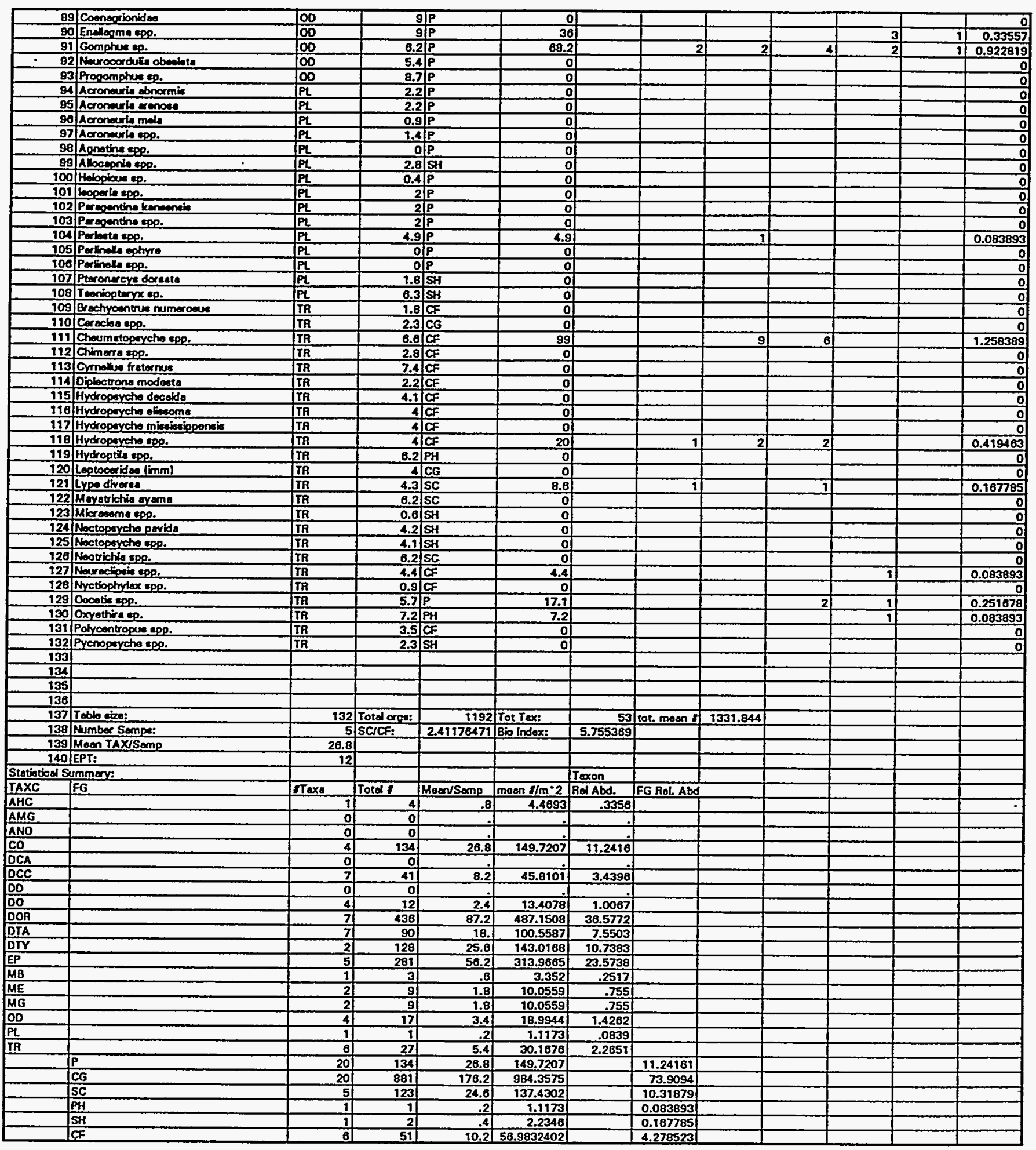


Taxa List:

Hydracarina

Ancyronyx variegatus

Helichus striatus

Macronychus glabratus

Stenelmis crenata

Cryptochironomus spp.

Dicrotendipes neomodestus

Dicrotendipes spp.

Polypedilum fallax

Polypedilum spp.

Saetheria sp.

Tribelos jucundum

Archipogon sp.

Ceratopogonidae

Hemerodromia spp.

Palpomyia spp.

Corynoneura spp.

Cricotopus/Ortho spp.

Nanocladius spp.

Parametriocnemus sp.

Rheocricotopus spp.

Thienemanniella spp.

Uniella multivirga

Ablabesmyia spp.

Conchapelopia spp.

Labrundinia spp.

Nilotanypus spp.

Paramerina sp.

Pentaneura inconspicua

Stempellina sp.

Rheotanytarsus spp.

Tanytarsus spp.

Baetis spp.

Ephemerella sp.

Isonychia sp.

Stenonema spp.

Tricorythodes spp.

Sphaerium sp.

Corydalus cornutus

Nigronia serricornis

Ferrissia sp.

Hydrobiidae

Boyeria vinosa

Calopteryx sp.

Enallagma spp.

Gomphus sp.

Perlesta spp.

Cheumatopsyche spp. 
PEN BR. RD.B 08/19/93 STATION 22

Hydropsyche spp.

Lype diversa

Neureclipsis spp.

Oecetis spp.

Oxyethira sp. 


\begin{tabular}{|c|c|c|c|c|c|c|c|c|c|c|c|}
\hline Seq & Taxon & TAXC & NCBI & FG & (for $\mathrm{BI})$ & Sampler Da/A & $\mathrm{B}$ & C & D & E & Rel Abd \\
\hline 1 & 1 Thienemanniella spp. & DOR & 6 & $\overline{C G}$ & 1470 & 80 & 58 & 102 & 4 & 1 & 20.55369 \\
\hline 2 & Tricorythodes spp. & $E P$ & 5.4 & CG & 815.4 & 23 & 19 & 59 & 24 & 28 & 12.66779 \\
\hline 3 & Tanytarsus spp. & DTY & 6.7 & $\mathrm{CG}$ & 763.8 & 39 & 23 & 38 & 8 & 6 & 9.563758 \\
\hline 4 & Stenonema spp. & EP & 3.4 & SC & 377.4 & 14 & 16 & 53 & 14 & 14 & 9.312081 \\
\hline 5 & Corynonoura spp. & DOR & 6.2 & CG & 489.8 & 35 & 11 & 17 & 1 & 15 & 6.627517 \\
\hline 6 & Macronychus glabratus & Co & 4.7 & CG & 338.4 & 6 & 27 & 28 & 9 & 2 & 6.040268 \\
\hline 7 & Rheocricotopus spp. & DOR & 7.3 & CG & 467.2 & 23 & 14 & 24 & 2 & 1 & 5.369128 \\
\hline & Ancyronyx yariegatus & Co & 8.9 & CG & 414 & 6 & 12 & 25 & 16 & 1 & 5.033557 \\
\hline
\end{tabular}




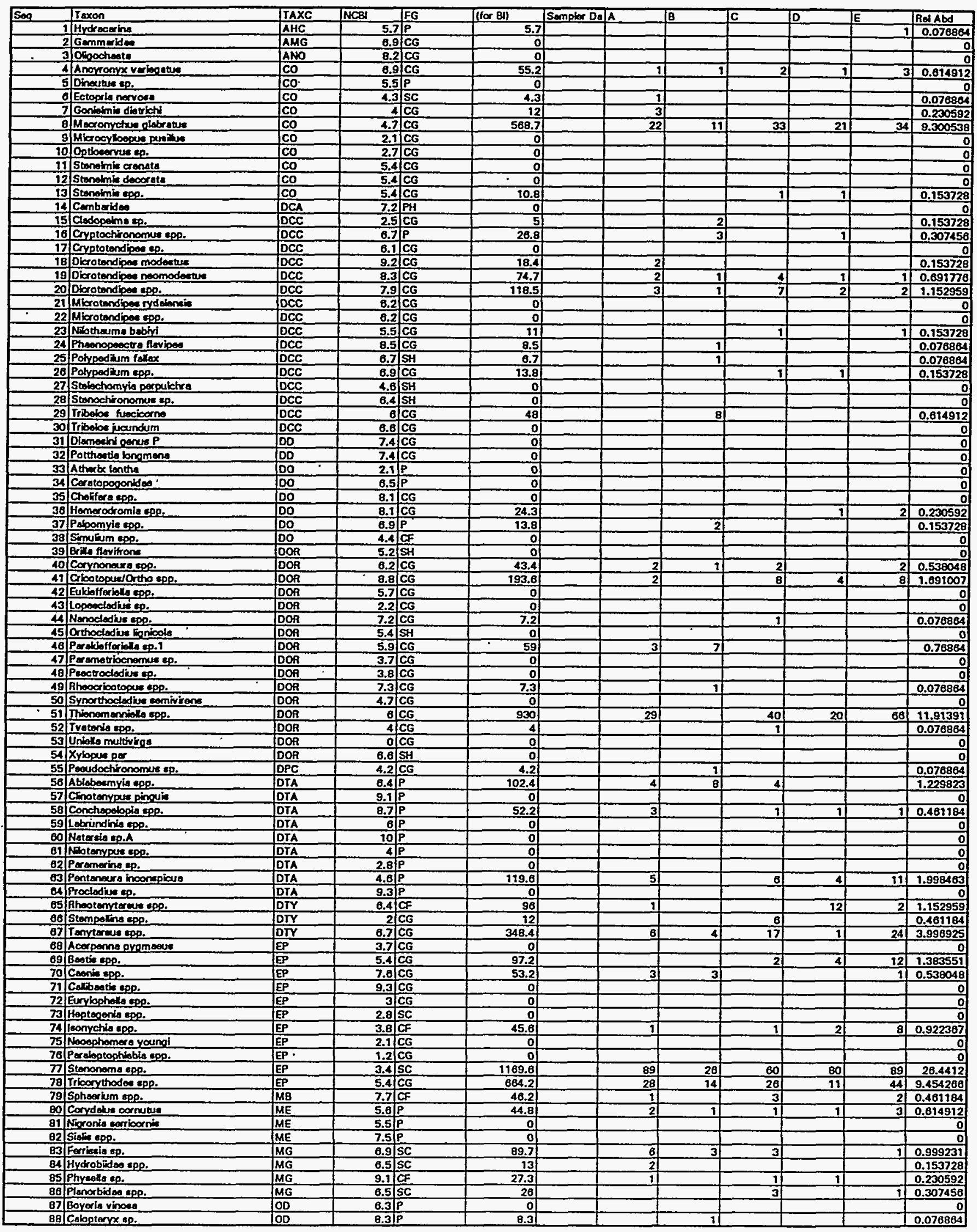




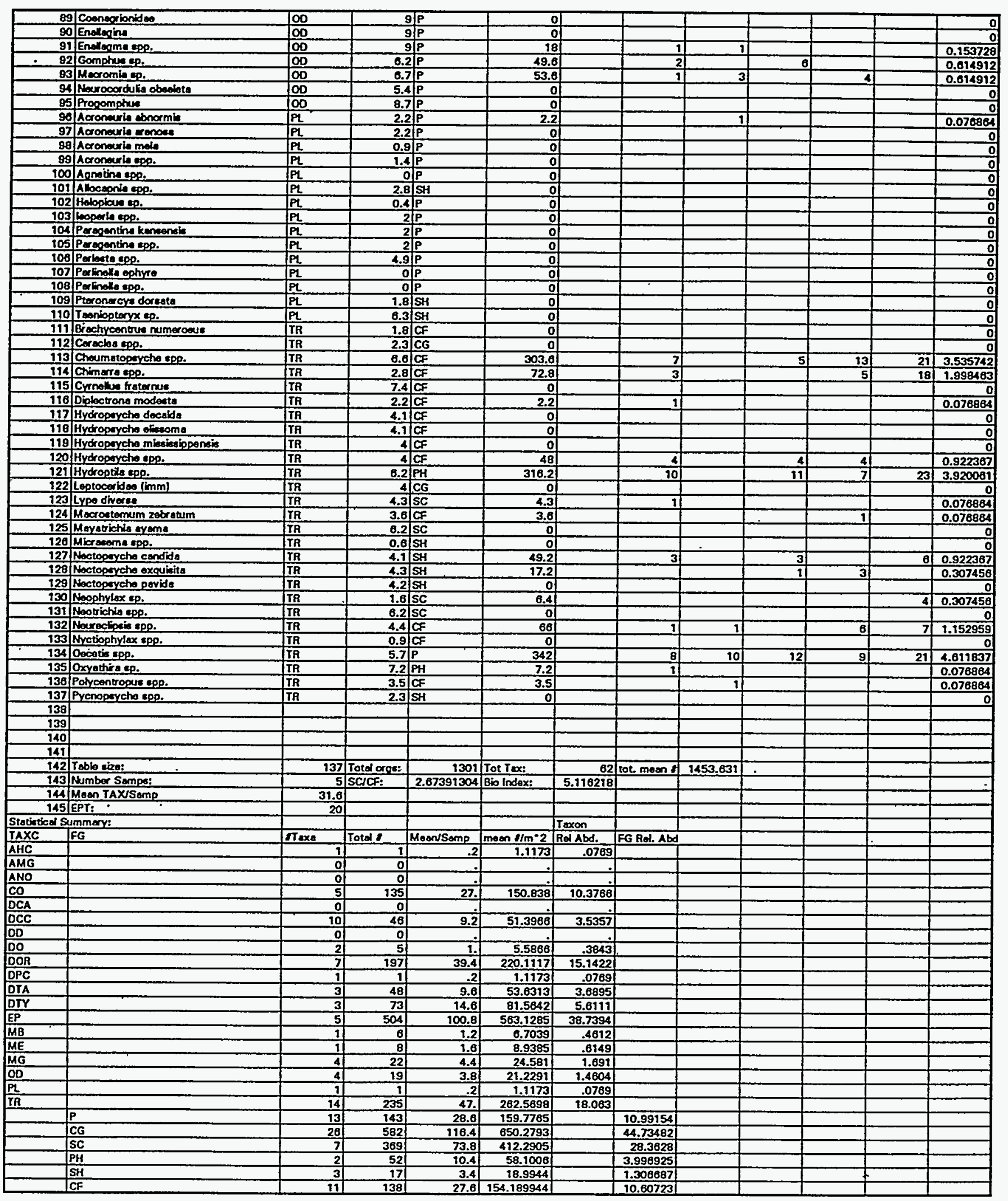




\begin{tabular}{|l|}
\hline Taxa List: \\
\hline Hydracarina \\
\hline Ancyronyx variegatus \\
\hline Ectopria nervosa \\
\hline Gonielmis dietrichi \\
\hline Macronychus glabratus \\
\hline Stenelmis spp. \\
\hline Cladopelma sp. \\
\hline Cryptochironomus spp. \\
\hline Dicrotendipes modestus \\
\hline Dicrotendipes neomodestus \\
\hline Dicrotendipes spp. \\
\hline Nilothauma babiyi \\
\hline Phaenopsectra flavipes \\
\hline Polypedilum fallax \\
\hline Polypedilum spp. \\
\hline Tribelos fuscicorne \\
\hline Hemerodromia spp. \\
\hline Palpomyia spp. \\
\hline Corynoneura spp. \\
\hline Cricotopus/Ortho spp. \\
\hline Nanocladius spp. \\
\hline Parakiefferiella sp.1 \\
\hline Rheocricotopus spp. \\
\hline Thienemanniella spp. \\
\hline Tvetenia spp. \\
\hline Pseudochironomus sp. \\
\hline Ablabesmyia spp. \\
\hline Conchapelopia spp. \\
\hline Pentaneura inconspicua \\
\hline Rheotanytarsus spp. \\
\hline Stempellina spp. \\
\hline Tanytarsus spp. \\
\hline Baetis spp. \\
\hline Caenis spp. \\
\hline Isonychia spp. \\
\hline Stenonema spp. \\
\hline Tricorythodes spp. \\
\hline Sphaerium spp. \\
\hline Corydalus cornutus \\
\hline Ferrissia sp. \\
\hline Hydrobiidae spp. \\
\hline Physella sp. \\
\hline Planorbidae spp. \\
\hline Calopteryx sp. \\
\hline Gomallagma spp. \\
\hline Macromia sp. \\
\hline
\end{tabular}


PEN BR. RD A 08/19/93 STATION 23

Cheumatopsyche spp.

Chimarra spp.

Diplectrona modesta

Hydropsyche spp.

Hydroptila spp.

Lype diversa

Macrostemum zebratum

Nectopsyche candida

Nectopsyche exquisita

Neophylax sp.

Neureclipsis spp.

Oecetis spp.

Oxyethira sp.

Polycentropus spp. 


\begin{tabular}{|c|c|c|c|c|c|c|c|c|c|c|c|}
\hline Seg & Taxon & TTAXC & NCBI & FG & (for Bl) & Sampler $\mathrm{Da} \mid \mathrm{A}$ & $\bar{B}$ & C & D & $E$ & Rel Abd \\
\hline 1 & Stenonema spp. & EP & $\overline{3.4}$ & sc & 1169.6 & 89 & 26 & 60 & 80 & 89 & 26.4412 \\
\hline 2 & Thienemanniella spp. & DOR & & CG & 930 & 29 & & 40 & 20 & 68 & 11.91391 \\
\hline 3 & Tricorythodes spp. & EP & 5.4 & CG & 664.2 & 28 & 14 & 28 & 11 & 44 & 9.454268 \\
\hline & Macronychus glabratus & co & 4.7 & CG & 568.7 & 22 & 11 & 33 & 21 & 34 & 9.300538 \\
\hline
\end{tabular}




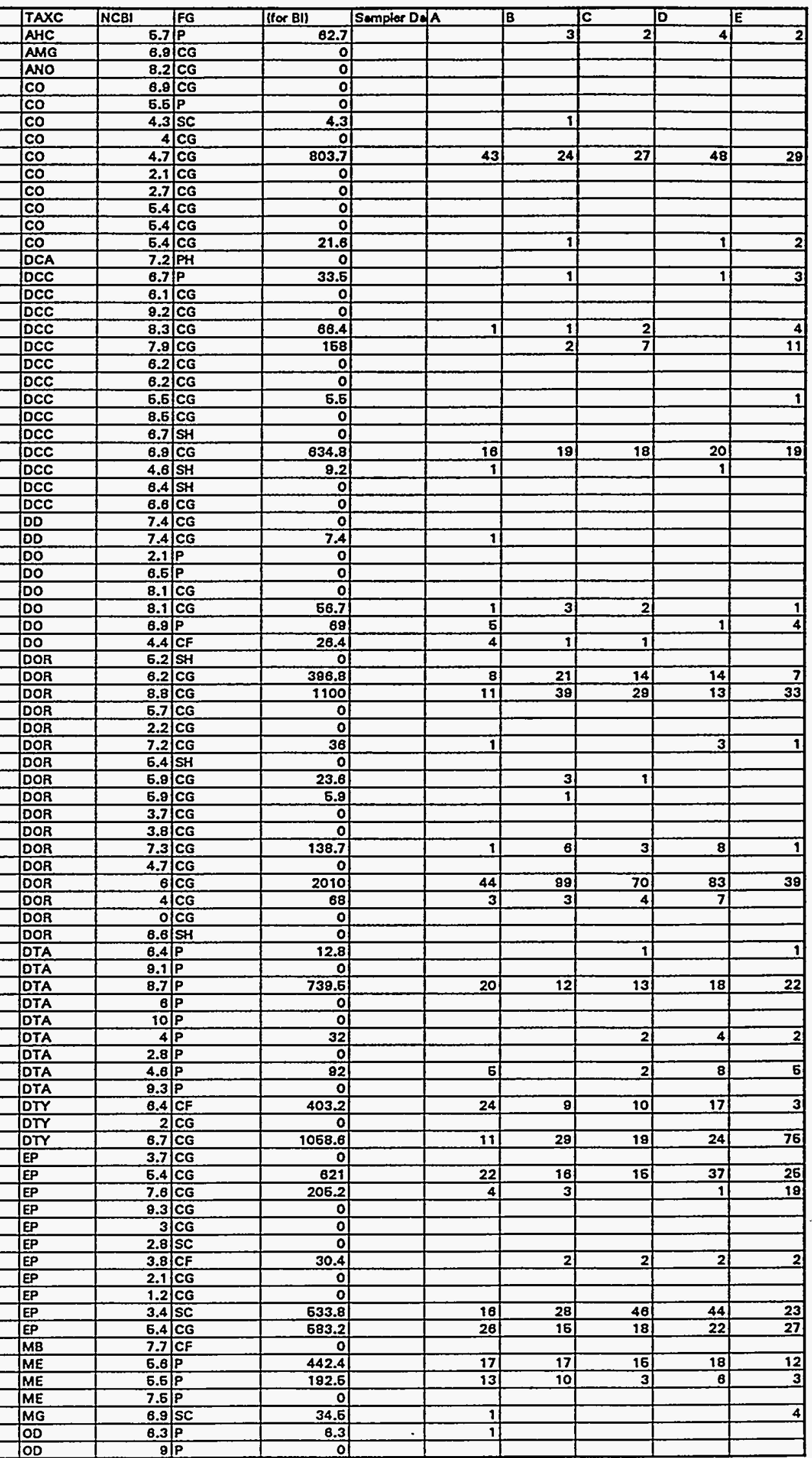




\begin{tabular}{|c|c|c|c|c|c|c|c|c|c|c|c|}
\hline 84 & Endlecme epp. & 100 & & P & 0 & & & & & & \\
\hline 86 & Neurocordulie obentote & 100 & 6.4 & $\mathbf{P}$ & 0 & & & & & & \\
\hline 88 & Progomphe ep. & OD & 8.7 & $P$ & 0 & & & & & & \\
\hline 87 & Acronecurie ebriormle & $P$ & 2.2 & $P$ & 4.4 & & 1 & & & 1 & \\
\hline 88 & Acronourin erenoes & PL & 2.2 & P & 0 & & & & & & \\
\hline 80 & Acronourie mele & PL & 0.9 & $P$ & 0 & & & & & & \\
\hline 80 & Acroneute epp. & IPL & 1.4 & $\mathbf{P}$ & 0 & & & & & & \\
\hline 91 & Aonotina spe. & IPL & 은 & $P$ & 0 & & & & & & \\
\hline 82 & Alloceonie epp. & PL & 2.8 & SH & 0 & & & & & & \\
\hline 83 & Helopienes. & $P L$ & 0.4 & $\mathbf{P}$ & 요 & & & & & & \\
\hline 24) & leoporie epp. & PL & 2 & $P$ & 우 & & & & & & \\
\hline 85 & Perceentina kencencele & PL & 2 & $P$ & 의 & & & & & & \\
\hline 96 & Pricoemtine sop. & $P L$ & 2 & P & 이 & & & & & & \\
\hline 07 & Perketa spp. & TPL & 4.8 & IP & 의 & & & & & & \\
\hline 98 & Pertinalle ephyre & PL & 요 & $P$ & 으 & & & & & & \\
\hline 88 & Porlinelia epp. & $P L$ & 의 & $P$ & 의 & & & & & & \\
\hline 100 & Pteronercye doreste & $P L$ & 1.8 & SH & 의 & & & & & & \\
\hline 101 & Teaniopteryx sp. & $P L$ & 6.3 & SH & 의 & & & & & & \\
\hline 102 & Brechycentrue numerosus & TR & 1.8 & CF & 의 & & & & & & \\
\hline 103 & Corecten epp. & TR & 2.3 & CG & 의 & & & & & & \\
\hline 104 & Choumatopeyche spp. & TR & 6.6 & CF & 1168.2 & & 47. & 43 & 27 & 43 & 17 \\
\hline 105 & Chimerre spp. & TR & 2.8 & CF & 828 & & 94) & 30 & 46 & 101 & 24 \\
\hline 106 & Cyrnellue fratornis & TR & 7.4 & CF & 요 & & & & & & \\
\hline 107 & Diplectrone modoets & TR & 2.2 & CF & 요 & & & & & & \\
\hline 108 & Hydropeyche decelda & ITR & 4.1 & $\mathrm{CF}$ & 의 & & & & & & \\
\hline 108 & Hydropayche eliseome & TR & 4 & CF & 의 & & & & & & \\
\hline 110 & Hydropoycho minalasippensia & TR & 4 & CF & 의 & & & & & & \\
\hline 111 & Hydropeycho apg. & TR & 4 & CF & 358 & & 30) & 13) & 11 & 30 & 5 \\
\hline 112 & Hydroptile spo. & TR & 6.2 & $\mathrm{PH}$ & 465 & & 6) & 3] & 22 & 24 & 20 \\
\hline 113 & Leptocentides (imm) & TR & 4 & CG & 의 & & & & & & \\
\hline 114 & Lype diveres & TR & 4.3 & sc & 의 & & & & & & \\
\hline 115 & Mecrostemum ceroline & TR & 3.8 & $\overline{C F}$ & 14.4 & & 3 & & & 1 & \\
\hline 118 & Mecrosternum zebretum & TR & 3.8 & $\mathrm{CF}$ & 7.2 & & & & & 1 & 1 \\
\hline 117 & Moyatrichie ayeme & TR & 6.2 & SC & 의 & & & & & $\rightarrow$ & \\
\hline 118 & Mleresome spp. & TR & 0.8 & SH & 의 & & & & & & \\
\hline 118 & Nectoperyche pavida & TR & 4.2 & SH & 29.4 & & & 1 & 1 & 2 & 3. \\
\hline 120 & Neotrichie spe. & TR & 6.2 & Sc & of & & & & 1 & 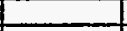 & 7 \\
\hline 121 & Neureclipeie spp. & TR & 4.4 & CF & 86.8 & & 6) & & 12 & 2 & 2 \\
\hline 122 & Nyetiophylex spp. & TR & 0.9 & CF & 0 & & 1 & & & & \\
\hline 123 & Oecetis spp. & TR & 6.7 & P & 125,4 & & 3 & 1 & 4) & 2 & 12 \\
\hline 124 & Polycentropus spe. & $T R$ & 3.5 & CF & 요 & & & & & & \\
\hline 126 & Pycnopaycho spp. & $T R$ & 2.3 & SH & o) & & & & & & \\
\hline \multicolumn{12}{|l|}{ 126 } \\
\hline \multicolumn{12}{|l|}{127} \\
\hline \multicolumn{12}{|c|}{ 12B } \\
\hline \multicolumn{12}{|l|}{128} \\
\hline 130 & Treble size: & 125 & Total oros: & 2476 & Tot Tex: & 47 & tot. mean & 2765.363 & & & \\
\hline 13i & Number Sempe: & E. & SC/CF: & 0.2447447 & Bio Index: & 6.683182 & & & & & \\
\hline 132 & Moen TAX/Semp & 34.2 & & & & & . & & & & \\
\hline 133) & EPT: & 15. & & & & & & & & & \\
\hline Statiotlcal Si & immery: & & & & & Texon & & & & & \\
\hline TAXC & $\mathbf{F G}$ & Traxa & Totel : & Mear/Semp & mean $: / m^{-2}$ & Rel Abd. & FG Rel. Abd & & & & \\
\hline AHC & & 1 & 11 & 2.2 & 12.2806 & .4444 & & & & & \\
\hline AMG & & 의 & 의 &. & .1 & $\therefore$ & & & & & \\
\hline ANO & & of & of & & & & & & & & \\
\hline CO & & 3 & 176 & 36.2 & 186.648 & 7.1111 & & & & & \\
\hline DCA & & of & of & & & & & & & & \\
\hline DCC & & B) & 128 & 26.6 & 143.0168 & 5.1717 & & & & & \\
\hline DD & & 1 & 1 & .2 & 1.1173 & .0404 & & & & & \\
\hline DO & & 3 & 23 & 4.6 & 26.8983 & .0283 & & & & & \\
\hline DOR & & 8 & 670 & 114. & 636.8716 & 23.0303 & & & & & \\
\hline DTA & & 4) & 116 & 23. & 128.4816 & 4.6465 & & & & & \\
\hline DTY & & 2 & 221 & 44.2 & 246.9274 & 8.8283 & & & & & \\
\hline EP & & 5 & 416 & 83. & 463.6872 & 16.7677 & & & & & \\
\hline MB & & 의 & 이 & & & & & & & & \\
\hline ME & & 2 & 114 & 22.8 & 127.3743 & 4.8081 & & & & & \\
\hline MG & & 1 & E) & 1. & 6.6868 & .202 & & & & & \\
\hline$O D$ & & 1 & 1 & .2 & 1.1173 & .0404 & & & & & \\
\hline PL. & & 1 & 2 & .4 & 2.2346 & .0808 & & & & & \\
\hline TR & & g. & 893 & 138.8 & 774.3017 & 28. & & & & & \\
\hline & $\mathbf{P}$ & 12 & 280 & 68. & 312.8492 & & 11.31313 & & & & \\
\hline & CG & 20 & 1282 & 258.4 & 1432.4022 & & 61.79798 & & & & \\
\hline & Sc & 3 & 163 & 32.8 & 182.1229 & & \begin{tabular}{|c|}
6.686869 \\
\end{tabular} & & & & \\
\hline & $\mathrm{PH}$ & 1 & 76 & 16. & 83.7889 & & 3.030303 & & & & \\
\hline & SH & 2 & 8 & 1.8 & 10.0669 & & 0.363638 & & & & \\
\hline & CF & 8 & 686 & 133.2 & 744.13408 & & 26.80909 & & & & \\
\hline
\end{tabular}




\begin{tabular}{|l|}
\hline Taxa List: \\
\hline Hydracarina \\
\hline Ectopria nervosa \\
\hline Macronychus glabratus \\
\hline Stenelmis spp. \\
\hline Cryptochironomus spp. \\
\hline Dicrotendipes neomodestus \\
\hline Dicrotendipes spp. \\
\hline Nilothauma babiyi \\
\hline Polypedilum spp. \\
\hline Stelechomyia perpulchra \\
\hline Potthastia longmana \\
\hline Hemerodromia spp. \\
\hline Palpomyia spp. \\
\hline Simulium spp. \\
\hline Corynoneura spp. \\
\hline Cricotopus/Ortho spp. \\
\hline Nanocladius spp. \\
\hline Parakiefferiella sp.1 \\
\hline Parakiefferiella sp.2 \\
\hline Rheocricotopus spp. \\
\hline Thienemanniella spp. \\
\hline Tvetenia spp. \\
\hline Ablabesmyia spp. \\
\hline Conchapelopia spp. \\
\hline Nilotanypus spp. \\
\hline Pentaneura inconspicua \\
\hline Rheotanytarsus spp. \\
\hline Tanytarsus spp. \\
\hline Baetis spp. \\
\hline Caenis spp. \\
\hline Isonychia spp. \\
\hline Stenonema spp. \\
\hline Tricorythodes spp. \\
\hline Corydalus cornutus \\
\hline Nigronia serricornis \\
\hline Ferrissia sp. \\
\hline Boyeria vinosa \\
\hline Acroneuria abnormis \\
\hline Cheumatopsyche spp. \\
\hline Chimarra spp. \\
\hline Hydropsyche spp. \\
\hline Hydroptila spp. \\
\hline Macrostemum carolina \\
\hline Macrostemum zebratum \\
\hline Nectopsyche pavida \\
\hline Neureclipsis spp. \\
\hline Oecetis spp. \\
\hline
\end{tabular}


PEN BR. RD. A 13.2 08/19/93 STATION 24 List of taxa $>5 \%$ relative abundance

\begin{tabular}{|c|c|c|c|c|c|c|c|c|c|c|c|c|}
\hline Seq & Taxon & TAXC & NCBI & FG & (for Bl) & Sampler Da & $A$ & $B$ & C & $D$ & $\mathbf{E}$ & Rel Abd \\
\hline 1 & Thienemanniella spp. & DOR & & CG & 2010 & & 44 & 99 & 70 & 83 & 39 & 13.53535 \\
\hline 2 & Chimarra spp. & $T R$ & 2.8 & CF & 826 & & 94 & 30 & 48 & 101 & 24 & 11.91919 \\
\hline 3 & Cheumatopsyche spp. & TR & $\overline{8.6}$ & CF & 1168.2 & & 47 & 43 & 27 & 43 & 17 & 7.151515 \\
\hline 4 & Macronychus glabratus & Co & 4.7 & CG & 803.7 & & 43 & 24 & 27 & 48 & 29 & 6.909091 \\
\hline 5 & Tanytarsus 8pp. & DTY & 6.7 & CG & 1058.6 & & 11 & 29 & 19 & 24 & 75 & 0.383838 \\
\hline 8 & Stenonema spp. & EP & 3.4 & Sc & 533.8 & & 18 & 28 & 46 & 44 & $\overline{23}$ & 6.343434 \\
\hline & Cricotopus/Ortho spp. & DOR & 8.8 & $\overline{C G}$ & 1100 & & 11 & 39 & 29 & 13) & 33 & 5.050505 \\
\hline
\end{tabular}




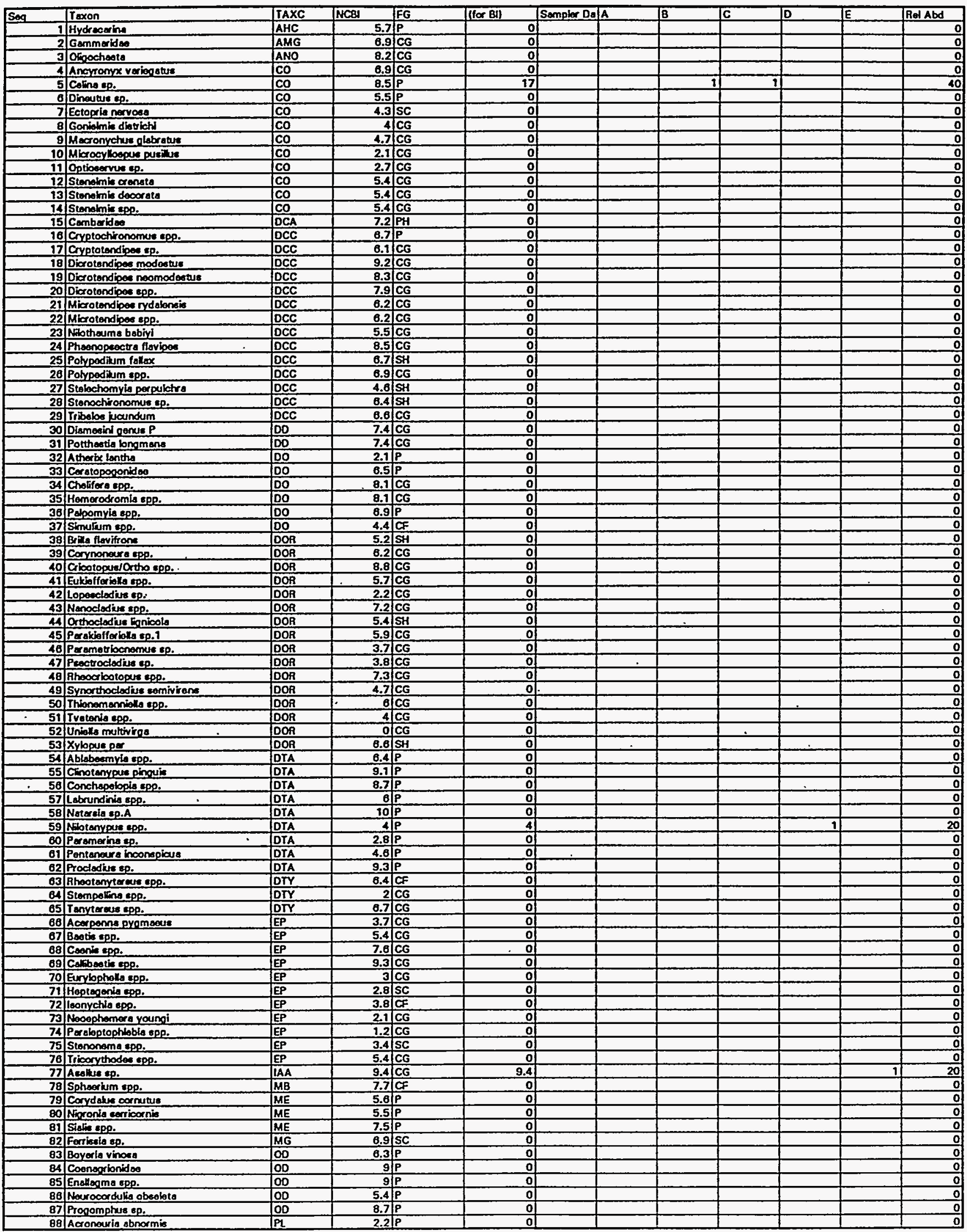




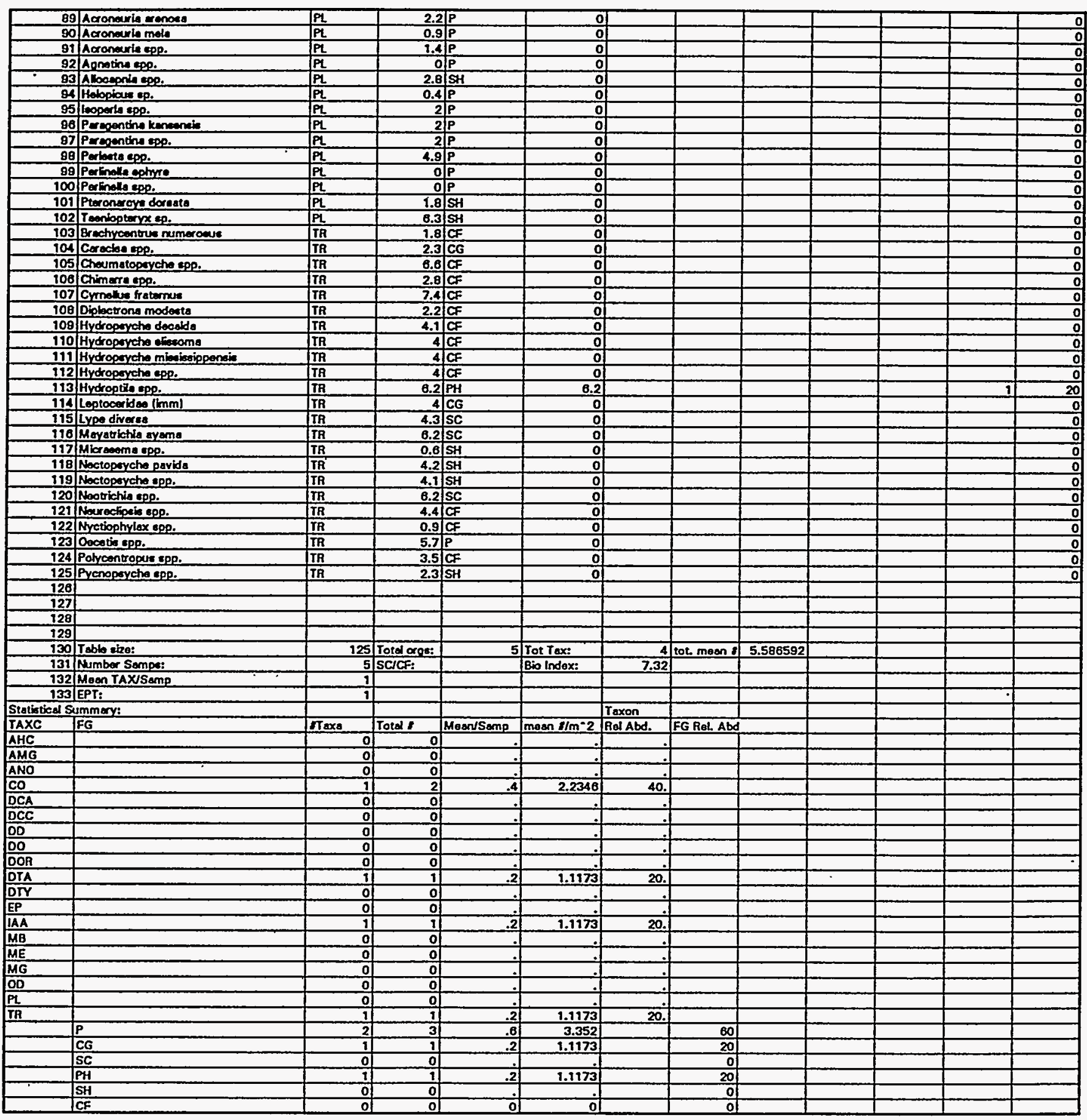


PEN BR. @ BOARDWALK 08/20/93 STATION 25

Taxa List:

Celina sp.

Nilotanypus spp.

Asellus sp.

Hydroptila spp. 


\begin{tabular}{|c|c|c|c|c|c|c|c|c|c|c|c|}
\hline$S_{e c}$ & Taxon & TAXC & NCBI & $\mathbf{F G}$ & (for BI) & Sampler Da A & B & C & D & $\mathbf{E}$ & Rel Abd \\
\hline & 1 Celina sp. & co & 8.5 & & 17 & & 1 & 1 & & & 40 \\
\hline & 2 Nilotanypus spp. & DTA & & $P$ & 4 & & & & 1 & & 20 \\
\hline & 3 Asellus sp. & IAA & 9.4 & CG & 9.4 & & & & & 1 & 20 \\
\hline & 4 Hydroptila spp. & ITR & 6.2 & PH & 6.2 & & & & & 1 & 20 \\
\hline
\end{tabular}




\begin{tabular}{|c|c|c|c|c|c|c|c|c|c|}
\hline Seq & Trexon & TIAXC & NACBI & FG & I(for $\theta$ ) & Sernpter De & $\sqrt{A}$ & T & TC \\
\hline 1 & Hydrocerine & AHC & 5.7 & $P$ & of & & & & \\
\hline 2 & Gommeriden & AMG & 8.9 & CG & of & & & & \\
\hline 3 & Ofopoctients & ANO & 8.2 & CG & 0 & & & & \\
\hline 4 & Ancyromyx velogates: & Co & 8.9 & CG & 0 & & & & \\
\hline 5 & Dineutur sp. & co & 5.5 & $P$ & 0 & & & & \\
\hline 6 & Ectopria nervosa & co & 4.3 & SC & 0 & & & & \\
\hline 7 & Goniolmis diatrich & co & 4 & CG & 의 & & & & \\
\hline$\overline{8}$ & Mecronychus olobrature & co & 4.7 & CG & of & & & & \\
\hline$\overline{9}$ & Milorocylloopus pusiugs & co & 2.1 & $\overline{C G}$ & 의 & & & & \\
\hline 10 & Optosenve ep. & Co & 2.7 & CG & of & & & & \\
\hline 11 & Iftencimic arenata & $\mathrm{CO}$ & 5.4 & CG & of & & & & \\
\hline 12 & Stenolnin decorata & coo & 5.4 & CG & 의 & & & & \\
\hline 13 & Stongimil epp. & co & 5.4 & CG & of & & & & \\
\hline 14 & Cemberides & DCA & 7.2 & $\mathbf{P H}$ & of & & & & \\
\hline 15 & Chironomus epp. & DCC & 9.8 & CG & 225.4 & & 1 & 6 & 8 \\
\hline 16 & Cryptochironomus epp. & DCC & 6.7 & $P$ & of & & & & \\
\hline 17 & Cryptotondipes sp. & DCC & 6.1 & CG & of & & & & \\
\hline 18 & Dicrotondipes madestus & DCC & 9.2 & CG & of & & & & \\
\hline 19 & Dioratandipes neomodectus & DOCC & 8.3 & CG & 0 & & & & \\
\hline 20 & Dicralondipes cop. & DCC & 7.9 & CG & of & & & & \\
\hline 21 & Kbafferulue dax & IDCC & 10 & CG & 120 & & 2 & 5 & 3 \\
\hline 22 & Mlarotondipos rydatornis & IDCC & 6.2 & CG & 의 & & & & \\
\hline 23 & Miarotendipes cpp. & DCC & 8.2 & CG & of & & & & \\
\hline 24 & Niocheuma babiyi & DCC & 5.5 & CG & of & & & & \\
\hline 25 & Omixar pica & DCC & 5 & CG & 5 & & 1) & & \\
\hline 26 & Phoonopecetrs flovipes & DCC & 8.5 & CG & 51 & & & 1 & 3 \\
\hline 27 & Polypodium folex & TOCE & 6.7 & SH & 6.7 & & I) & & \\
\hline 28 & Polypodium spp. & DCC & 6.9 & CG & 6.9 & & & 1 & \\
\hline 29 & If Statachomyis perpulchra & DCC & 4.6 & SH & of & & & & \\
\hline 30 & Stonochitonomus tep. & DOCC & 8.4 & SH & of & & & & \\
\hline 31 & Tribotos juoundum & DCC & 8.6 & CG & 600.8 & & 17 & 21 & 21 \\
\hline$\overline{32}$ & Diamotini penese $P$ & $\overline{D O D}$ & 7.4 & CG & 0 & & & & \\
\hline 33 & Potthestio bonomans & $D D$ & 7.4 & CG & 의 & & & & \\
\hline 3 & Atherix lenthe & 100 & 2.1 & $\overline{\mathbf{P}}$ & o) & & & & \\
\hline 35 & Ceratopogonidos & 100 & 6.5 & $\mathbf{P}$ & 6.5 & & 1 & & \\
\hline 38 & Chollfera epp. & 100 & 8.1 & CG & of & & & & \\
\hline 37 & Hemerodromia eeg. & DO & 8.1 & $\overline{C G}$ & of & & & & \\
\hline 39 & Palpomyia \&pg. & 100 & 8.9 & $\mathbf{P}$ & 6.9. & & & & \\
\hline 39 & Simuteum epp. & 100 & 4.4 & CF & of & & & & \\
\hline 40 & Brita flovifrons & DOA & 5.2 & $\mathbf{S H}$ & a) & & & & \\
\hline 41) & Corynoneure epp. & DOR & 6.2 & CG & of & & & & \\
\hline 12 & Crioolopue/Ortho epp. & DOR & B.8 & CG & 6.8 & & & & \\
\hline 43 & Eukiolforialls spp. & DOR & 5.7 & CG & 0 & & & & \\
\hline 44 & Lopeselodive sp. & DOR & 2.2 & CG & of & & & & \\
\hline 45 & Nenocladius spe. & DOR & 7.2 & CG & 이 & & & & \\
\hline 40 & Crthociodius Fonicola & DOR & 5.4 & SH & of & & & & \\
\hline 47 & Parabiofforiale ep.1 & DOR & 5.9 & CG & of & & & & \\
\hline 48 & Permotiocnomus sp. & DOR & 3.7 & CG & - & & & & \\
\hline 49 & Peoctrocladius sp. & DOR & 3.8 & CG & of & & & & \\
\hline 50 & Aheocriootopurespp. & DOR & 7.3 & CG & of & & & & \\
\hline 51 & Synorthoctodive somivitions & DOR & 4.7 & CG & of & & & & \\
\hline 52 & Thionem anniols spp. & DOR & (6) & CG & of & & & & \\
\hline 53 & Tratonis spp. & DOR & 4 & CG & 의 & & & & \\
\hline 54 & Uniole multivirga & DOR & $\mathbf{0}$ & CG & of & & & & \\
\hline 55 & Xylopus pe & DOR & 6.8 & SH & of & & & & \\
\hline 56 & Ablebremyia spp. & DIA & 6.4 & $\mathbf{P}$ & 12.8 & & & & \\
\hline 57 & Cinotenypue pinouis & DIA & 9.1 & $\mathbf{P}$ & of & & & & \\
\hline 58 & Conchopelopio apg. & TOTA & 8.7 & $\mathbf{P}$ & of & & & & \\
\hline 59 & Lebrundinia spp. & DIA & $\bar{\theta}$ & $\mathbf{P}$ & of & & & & \\
\hline 60 & Natersia ep.A & DTA & 10 & P & of & & & & \\
\hline 61 & NEbtemypus epp. & Dora & 4 & $\mathbf{P}$ & of & & & & \\
\hline 62 & Peamerina eg. & DTA & 2.8 & P & of & & & & \\
\hline 63 & Pentemeara hoonspious & DTA & 4.8 & P & of & & & & \\
\hline e4 & Proclodive op. & DTA & 9.3 & P & of & & & & \\
\hline 65 & Ahootenytereus spp. & DIY & 6.4 & CF & of & & & & \\
\hline 68 & Stampoline epp. & DTY & $\overline{2}$ & CG & of & & & & \\
\hline 67 & Tanytereus epp. & DTY & 6.7 & CG & 13.4 & & 1 & & \\
\hline 68 & Acerperns pyomsecus & EP & 3.7 & CG & of & & & & \\
\hline 69 & Rootis spp. & EP & 5.4 & CG & of & & & & \\
\hline 70 & Coonis epp. & EP & 7.6 & CG & 0. & & & & \\
\hline 71 & Colliboetis epp. & EP & 9.3 & CG & of & & & & \\
\hline 72 & Eurykophalls epp. & EP & 3 & CG & of & & & & \\
\hline 73 & Heptogenis spo. & EP & 2.8 & SC & of & & & & \\
\hline 74 & leonychia epp. & EP & 3.8 & CF & 0 & & & & \\
\hline 75 & Nooophomere young & EP & 2.1 & CG & 의 & & & & \\
\hline 78 & Peraloptophlobia epp. & EP & 1.2 & CG & 0 & & & & \\
\hline 77 & Stanonamo cpp. & EP & 3.4 & SC & of & & & & \\
\hline 78 & Trioorythodes cpp. & EP & 5.4 & CG & of & & & & \\
\hline 79 & Sphoerium ipp. & MB & 7.7 & CF & 이 & & & & \\
\hline 80 & Corydelue corrutus & ME & 5.6 & $\mathbf{P}$ & of & & & & \\
\hline B1 & Nigronis eerrioornie & ME & 5.5 & $\mathbf{P}$ & 0 & & & & \\
\hline 82 & Stolis epp. & ME & 7.5 & $\bar{p}$ & 0 & & & & \\
\hline 83 & Forticatio sp. & MG & 6.9 & SC & 0| & & & & \\
\hline BA & Boyerin vinosa & OD & 6.3 & $\bar{p}$ & 0 & & & & \\
\hline 85 & Connoprionid os & $O D$ & 9 & $\bar{P}$ & 0 & & & & \\
\hline 88 & Ensllegma spp. & 100 & 9 & $\mathbf{P}$ & of & & & & \\
\hline 87 & Nerorocoxdulia obsolata & 100 & 5.4 & $P$ & of & & & & \\
\hline B8 & Propomphusis & 00 & 8.7 & $\mathbf{P}$ & 0 | & & & & \\
\hline
\end{tabular}




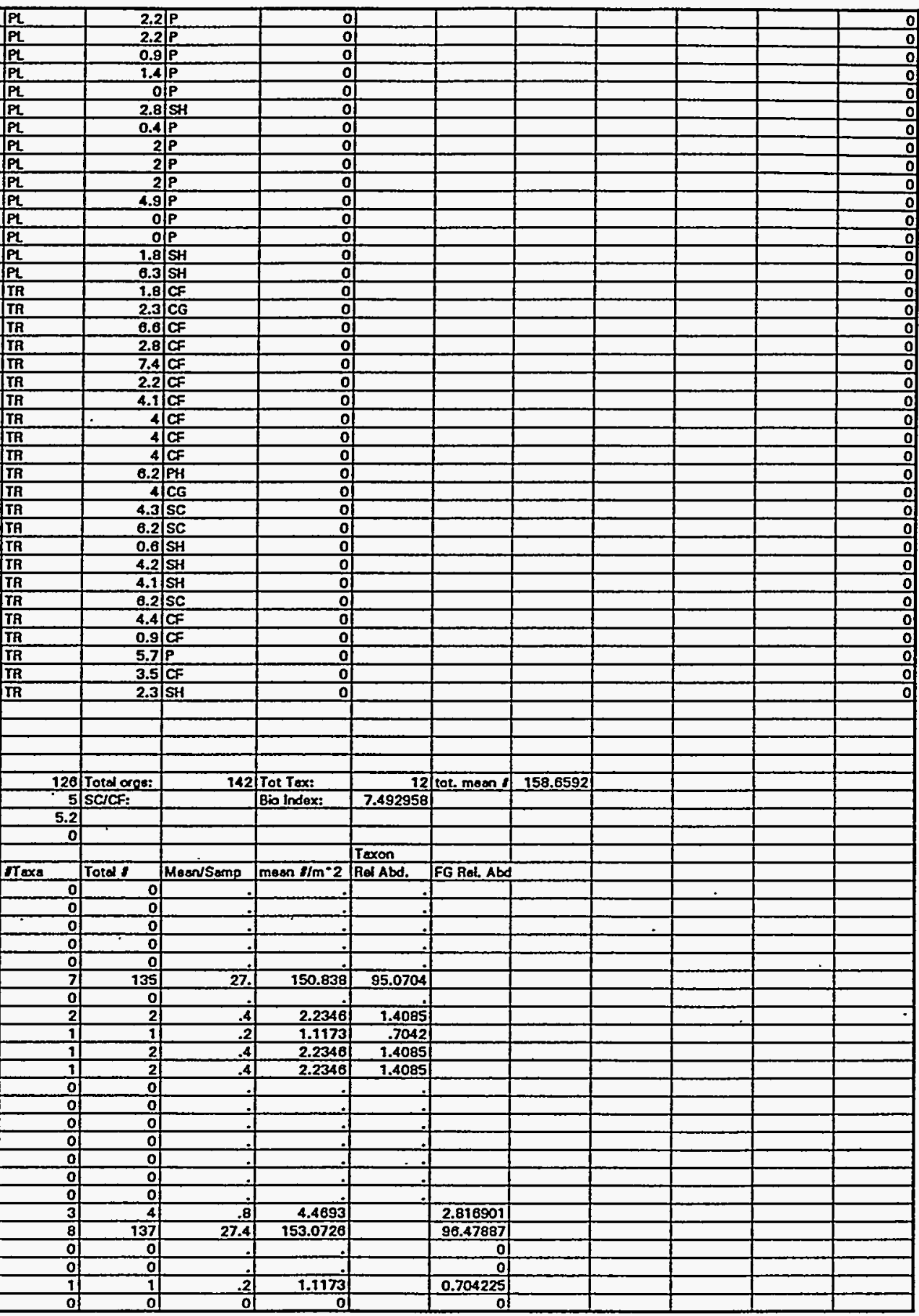




\section{PEN BR. RD C 08/20/93 STATION 26}

Taxa List:

Chironomus spp.

Kiefferulus dux

Omisus pica

Phaenopsectra flavipes

Polypedilum fallax

Polypedilum spp.

Tribelos jucundum

Ceratopogonidae

Palpomyia spp.

Cricotopus/Ortho spp.

Ablabesmyia spp.

Tanytarsus spp. 


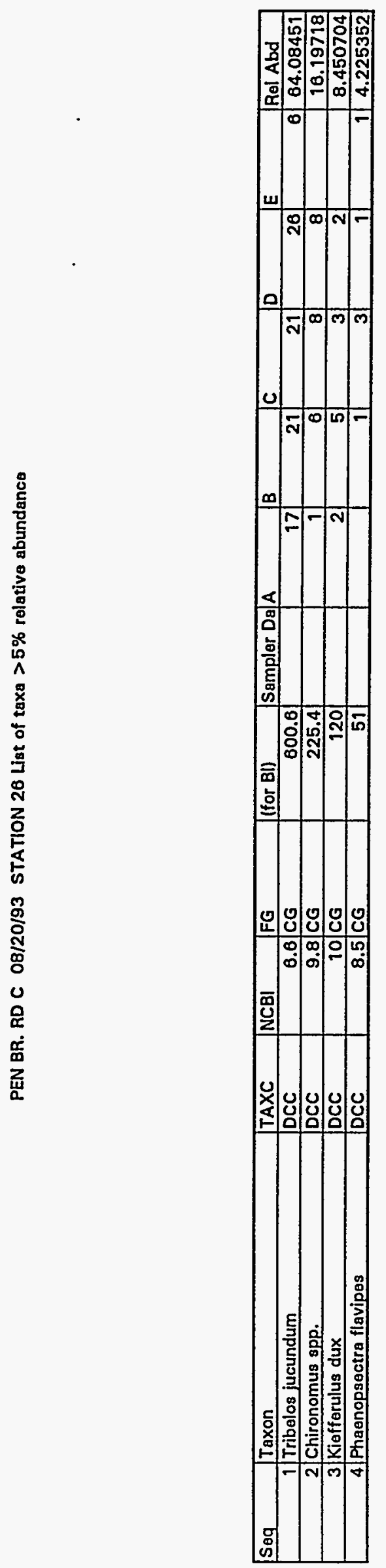




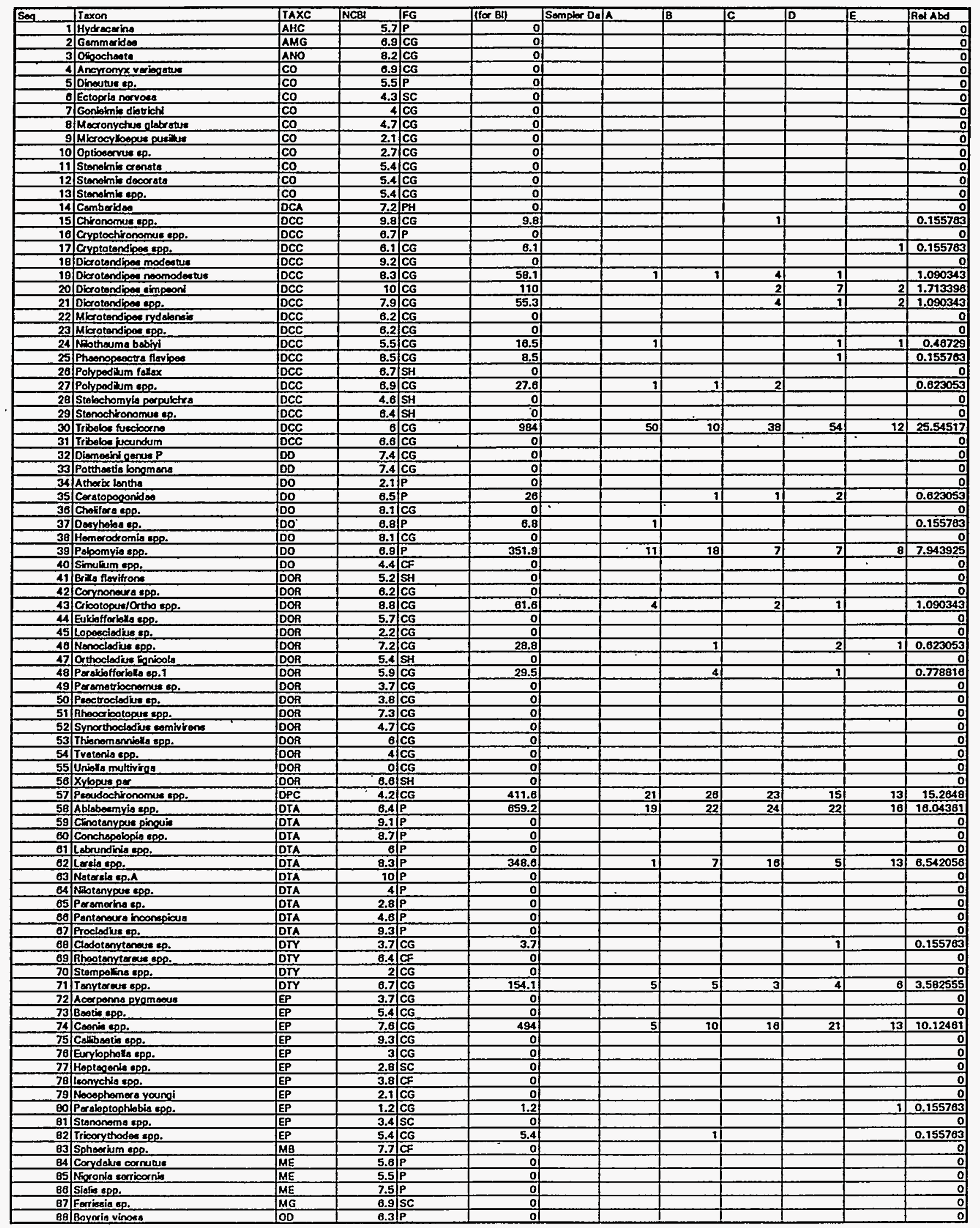




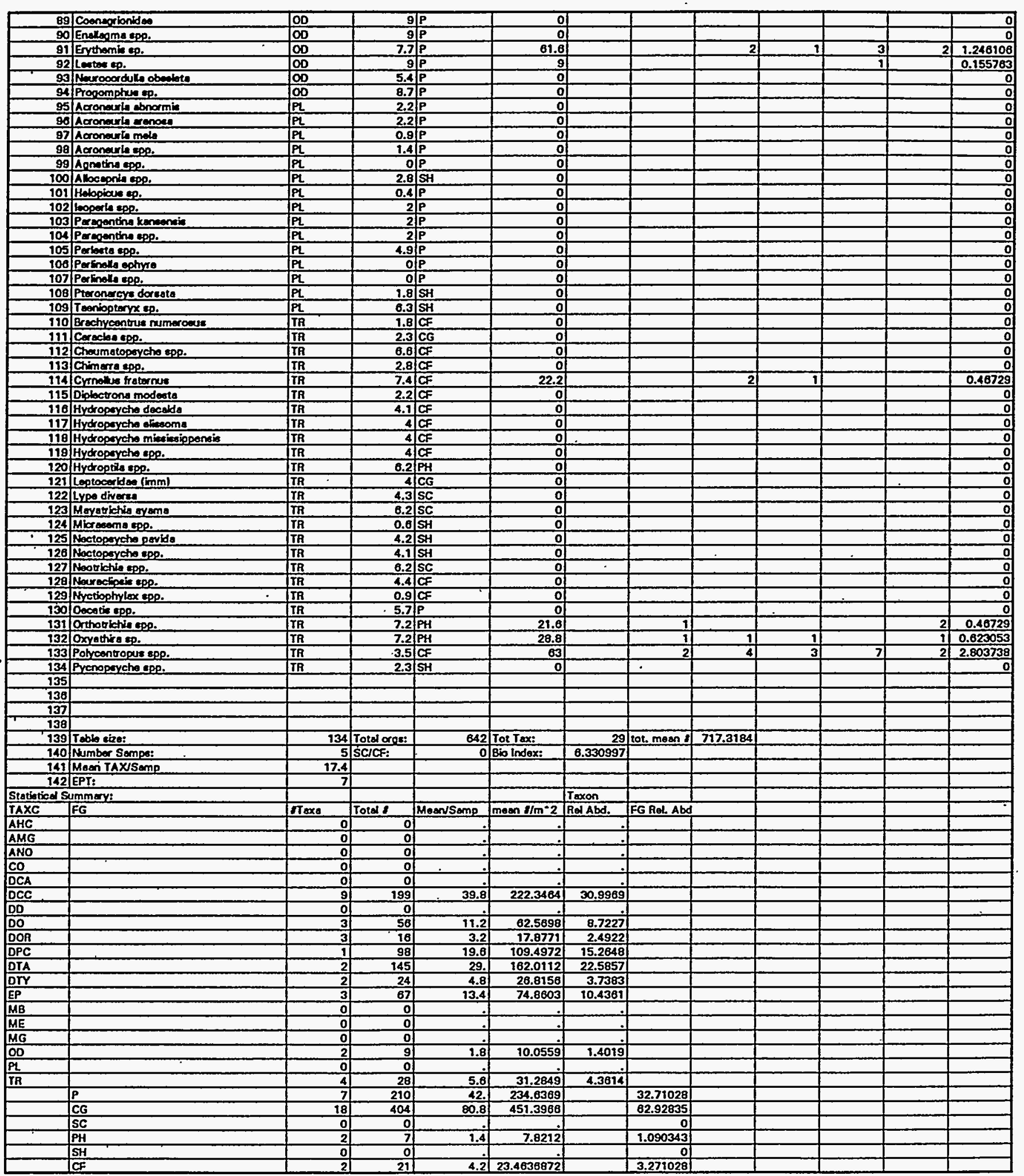




\begin{tabular}{|l|}
\hline Taxa List: \\
\hline Chironomus spp. \\
\hline Cryptotendipes spp. \\
\hline Dicrotendipes neomodestus \\
\hline Dicrotendipes simpsoni \\
\hline Dicrotendipes spp. \\
\hline Nilothauma babiyi \\
\hline Phaenopsectra flavipes \\
\hline Polypedilum spp. \\
\hline Tribelos fuscicorne \\
\hline Ceratopogonidae \\
\hline Dasyhelea sp. \\
\hline Palpomyia spp. \\
\hline Cricotopus/Ortho spp. \\
\hline Nanocladius spp. \\
\hline Parakiefferiella sp.1 \\
\hline Pseudochironomus spp. \\
\hline Ablabesmyia spp. \\
\hline Larsia spp. \\
\hline Cladotanytansus sp. \\
\hline Tanytarsus spp. \\
\hline Caenis spp. \\
\hline Paraleptophlebia spp. \\
\hline Tricorythodes spp. \\
\hline Erythemis sp. \\
\hline Lestes sp. \\
\hline Cyrnellus fraternus \\
\hline Orthotrichia spp. \\
\hline Oxyethira sp. \\
\hline Polycentropus spp. \\
\hline
\end{tabular}




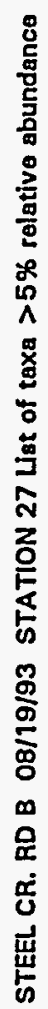

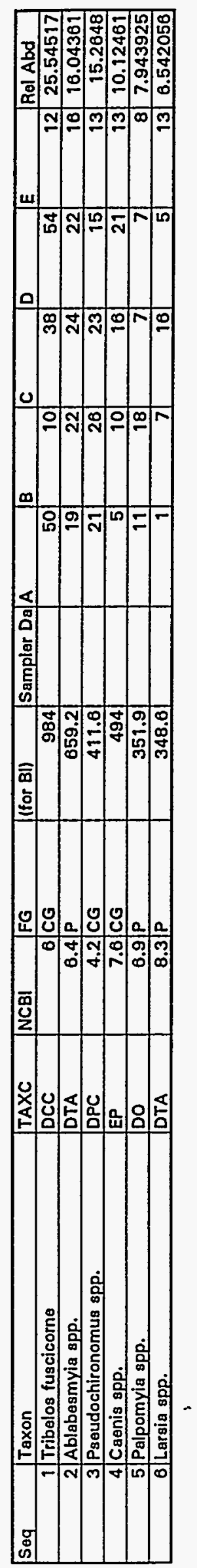




\begin{tabular}{|c|c|c|c|c|c|c|c|c|c|}
\hline Seg & Taxon & Taxc & NCBS & FG & (for BN) & Sampler Da & A & B & c \\
\hline & Hydrecerine & AHC & 5.7 & $P$ & 85.5 & & & 7 & 8) \\
\hline 2 & 2 Gemmerides & AMG & 6.9 & CG & of & & & & \\
\hline & 3 Otopcheate & ANO & 8.2 & CG & 0 & & & & \\
\hline & I Anorronyx veriegstus & co & 8.9 & CG & 48.3 & & & 3 & 1 \\
\hline 5 & 5 Dineutus ep. & co & 5.5 & $\mathbf{P}$ & 5.5 & & & & at \\
\hline & Eetopeta nervaces & co & 4.3 & SC & 107.5 & & 7 & 2 & 8 \\
\hline 7 & 7 Goniainie diatrichl & Co & 4 & CG & of & & & & \\
\hline 量 & 9 Mecronychus glabestue & Co & 4.7 & CG & 404.2 & & 10 & 13 & 19 \\
\hline 可 & 9 Microcylospue puritie & Co & 2.1 & CG & of & & & & 1 \\
\hline 10 & optionarvus & co & 2.7 & CG & of & & & & \\
\hline 11 & 1 Stonoknie cronata & co & 5.4 & CG & 아 & & & & \\
\hline 12 & 2 Stenaimis decorate & co & 5.4 & CG & of & & & & \\
\hline 13 & 3 Stonolmis cpp. & Co & 5.4 & CG & of & & & & \\
\hline 14 & Cornbarides & DCA & 7.2 & $\mathrm{PH}$ & of & & & & \\
\hline 15 & 5 Cryptochironomule spp. & DCC & 6.7 & $P$ & 6.7 & & & & 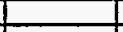 \\
\hline 10 & Cryptotondipes sp. & DCC & 6.1 & CG & o & & & & \\
\hline 17 & Dicrotendipes modestus & IDCC & 9.2 & CG & 의 & & & & \\
\hline 18 & 8 Dicrotendipes meomodecturs & DCC & 8.3 & CG & 99.6 & & 3 & 5 & 3 \\
\hline 19 & Dicrotendipesepp. & DCC & 7.9 & GG & 71.1 & & & 2 & 6) \\
\hline 20 & 5 Hicrotondipes ryd olareis & DCC & 6.2 & CG & of & & & & \\
\hline 21 & Microtendipos epp. & DCC & 6.2 & CG & of & & & & \\
\hline 22 & 2 Nilotheums bebiyl & DCC & 5.5 & CG & of & & & & \\
\hline 23 & 3 Peroctedopoing ip. & $D C C$ & 6.4 & CG & 12.8 & & & 1 & 1 \\
\hline 24 & Phosonopectra flevioes & DCC & 8.5 & $\overline{\mathbf{C G}}$ & of & & & & \\
\hline 25 & 5 Polypedinum follox & DCC & 8.7 & SH & 20.1 & & & & 2) \\
\hline 20 & Polypeditum cpp. & DCC & 8.9 & CG & 34.5 & & 1 & & 2 \\
\hline 27 & 7 Stelochomyie perpulecha & DOCC & 4.6 & SH & of & & & & \\
\hline 28 & Stonochironomuse sp. & DCC & 0.4 & SH & of & & & & \\
\hline 29 & Tribalos funcioxne & DCC & 6) & CG & 24 & & & & 4 \\
\hline 30 & Tribalos joundum & DCC & 8.6 & CG & 의 & & & & \\
\hline 31 & Diemexing genus $P$ & DD & 7.4 & CG & of & & & & \\
\hline 32 & Potthestia Longmana & DD & 7.4 & CG & of & & & & \\
\hline 33 & Atherix lenthe & DO & 2.1 & $P$ & 의 & & & & \\
\hline 34 & Coratopoponidos & 100 & 6.5 & $\mathbf{P}$ & 의 & & & & \\
\hline 35 & Shohferasepe. & DO & 8.1 & CG & of & & & & \\
\hline 38 & Hemerodromin sgp. & DO & 8.1 & $\mathbf{C G}$ & 72.9 & & 1 & & 2 \\
\hline 37 & Palpomyia spg. & DO & 6.9 & $P$ & 20.7 & & 2 & & \\
\hline 38 & 3 Simultum cpp. & DO & 4.4 & CF & 13.2 & & 2 & & \\
\hline 39 & Brito flavifrons & DOR & 5.2 & $\mathbf{S H}$ & of & & & & \\
\hline 40 & Corynonara spe: & DOR & 0.2 & CG & 99.2 & & 1 & (4) & 1) \\
\hline 11 & Crioolopuelortho spp. & DOR & 8.8 & CG & 959.2 & & 32 & 28 & 35 \\
\hline 42 & Eukbafieriolla epo. & DOR & 5.7 & CG & 의 & & & & \\
\hline 43 & Loposclodius $\mathrm{EP}$. & DOA & 2.2 & $\mathbf{C G}$ & of & & & & \\
\hline 4 & Nenocledius cop. & DOA & 7.2 & CG & of & & & & \\
\hline 45 & Orthoctedive Ennicole & DOA & 5.4 & SH & 이 & & & & \\
\hline 46 & 3) Perakbafferiole cp.1 & DOA & 5.9 & CG & 5.9 & & 1 & & \\
\hline 47) & Perametribcnomus ep. & DOA & 3.7 & CG & 이 & & & & \\
\hline 48 & Peoctroclodive sp. & DOR & 3.8 & $\mathbf{C G}$ & of & & & & \\
\hline 48 & Phooctiontopese epp. & DOA & 7.3 & CG. & 43.8 & & 3 & & \\
\hline 50 & Synorthoctodius somivirans. & DOA & 4.7 & CG & o & & & & \\
\hline 51 & IThonomamiolla spp. & DOR & 6) & CG & 438 & & ㄱ․ & 13 & 의 \\
\hline 52 & Iratonia spep. & DOR & 4 & CG & 의 & & & & \\
\hline 53 & Uniollo mufúviras & DOR & of & CG & of & & & & \\
\hline 54 & Xylopus per & DOR & 6.0 & SH & of & & & & \\
\hline 55 & Abloboum is cep. & Dra & 6.4 & $\mathbf{P}$ & 89.6 & & 1 & 2 & 10 \\
\hline 56 & Crnotenypus pinquis & DTA & 9.1 & $\mathbf{P}$ & of & & & & \\
\hline 57 & Conchepolopla tpp. & DTA & 8.7 & $\mathbf{P}$ & of & & & & \\
\hline 58 & Lebrundinis epp. & IDTA & B) & $\mathbf{P}$ & of & & & & \\
\hline 59 & Natercia ep.A & DIA & 10 & $P$ & of & & & & \\
\hline 60 & Niplanypu: epp. & DTA & 4 & $\mathbf{P}$ & 의 & & & & \\
\hline 01 & Peremering ep. & DTA & 2.8 & $\mathbf{P}$ & of & & & & \\
\hline 62 & Pentenaura inconspicua & DIA & 4.8 & $\mathbf{P}$ & 202.2 & & 18 & 7 & 17 \\
\hline 63 & Procledive ep. & DTA & 9.3 & $\mathbf{P}$ & of & & & & \\
\hline B4 & I Rhootenytercus spp. & DTY & 6.4 & CF & 102.4 & & 5) & & \\
\hline 65 & Stompolins spp. & ory & 2 & CG & of & & & & \\
\hline 68 & Iepyteroue epp. & DTY & 6.7 & CG & 80.4 & & 2 & 2 & 8 \\
\hline 67) & Acerperne pyomesus: & EP & 3.7 & CG & of & & & & \\
\hline 68 & Beotis epp. & EP & 5.4 & CG & 75.6 & & 1 & 21 & 1 \\
\hline 09 & Coonis epp. & EP & 7.6 & CG & of & & & & \\
\hline 70 & Colibatis epp. & EP & 9.3 & CG & of & & & & \\
\hline 71 & Eurybahollo spp. & EP & 3 & CG & 의 & & & & \\
\hline 72 & Heptegentis spp. & EP & 2.8 & SC & of & & & & \\
\hline 73 & leonychia epp. & EP & 3.8 & CF & 38) & & 3 & 2 & \\
\hline 74 & Neoosphamera youngl & EP & 2.1 & CG & of & & & & \\
\hline 75 & Probaptophlobla epp. & EP & 1.2 & CG & of & & & & \\
\hline 78 & Stononems epp. & EP & 3.4 & SC & 1094.8 & & 66 & 53 & 47) \\
\hline 77 & Tricorythodes spp. & $E P$ & 5.4 & CG & 194.4 & & 8 & 3 & 11 \\
\hline 78 & Parsooynx ep. & LEP & 5 & PH & 15 & & 1 & & \\
\hline 79 & Sphocrium epp. & $M B$ & 7.7 & CF & of & & & & \\
\hline 00 & Corydakes corneunse & $M E$ & 5.6 & $\mathbf{P}$ & 16.8 & & & 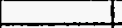 & \\
\hline 81 & Nigronia sarrioornis & $M E$ & 5.5 & $P$ & 5.5 & & & 1 & \\
\hline 82 & Stistis spg. & $M E$ & 7.5 & $\mathbf{P}$ & of & & & & \\
\hline 83 & Forriosia sp. & MG & 6.9 & SC & 48.3 & & & 1) & 1 \\
\hline B4 & Hydrobiedoo & MG & 6.5 & SC & 6.5 & & & 1) & 7 \\
\hline 85 & Physolla spp. & MG & 9.1 & SC & 81.9 & & & 2 & 3) \\
\hline 86 & Boyeta vinose & $O D$ & 6.3 & $\mathbf{P}$ & of & & & & \\
\hline 87 & Coonsorionides & 00 & 9 & $\mathbf{P}$ & of & & & & \\
\hline 88 & Enollenme spp. & 100 & 91 & $\mathbf{P}$ & 의 & & & & \\
\hline
\end{tabular}




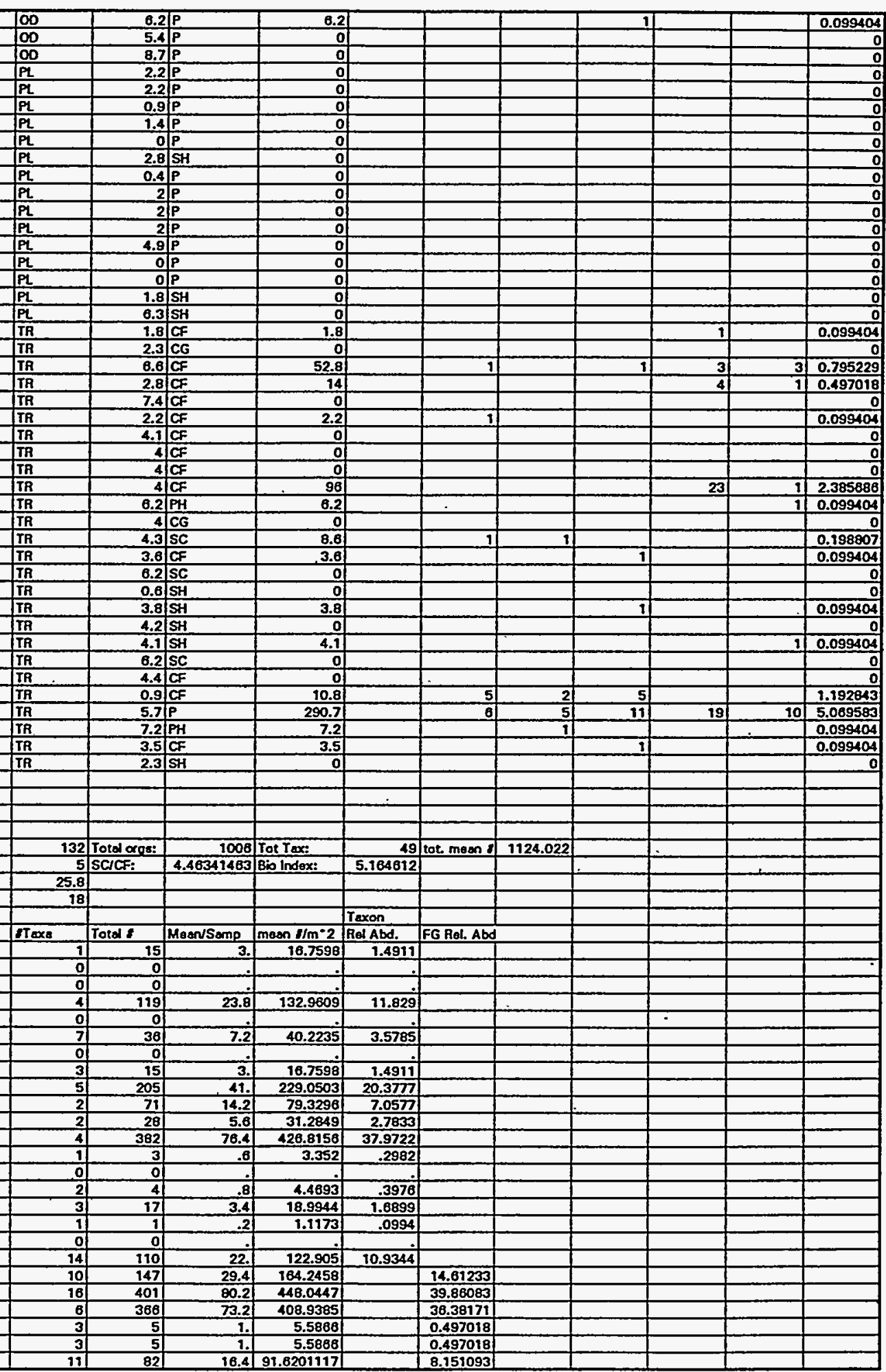


Taxa List:

Hydracarina

Ancyronyx variegatus

Dineutus sp.

Ectopria nervosa

Macronychus glabratus

Cryptochironomus spp.

Dicrotendipes neomodestus

Dicrotendipes spp.

Paracladopelma sp.

Polypedilum fallax

Polypedilum spp.

Tribelos fuscicorne

Hemerodromia spp.

Palpomyia spp.

Simulium spp.

Corynoneura spp.

Cricotopus/Ortho spp.

Parakiefferiella sp.1

Rheocricotopus spp.

Thienemanniella spp.

Ablabesmyia spp.

Pentaneura inconspicua

Rheotanytarsus spp.

Tanytarsus spp.

Baetis spp.

Isonychia spp.

Stenonema spp.

Tricorythodes spp.

Parapoynx sp.

Corydalus cornutus

Nigronia serricornis

Ferrissia sp.

Hydrobiidae

Physella spp.

Gomphus sp.

Brachycentrus numerosus

Cheumatopsyche spp.

Chimarra spp.

Diplectrona modesta

Hydropsyche spp.

Hydroptila spp.

Lype diversa

Macrostamum zebratum

Nectopsyche candida

Nectopsyche spp.

Nyctiophylax exquista

Oecetis spp.

Oxyethira sp. 
STEEL CR. @ RD A 08/19/93 STATION 28

Polycentropus spp. 


\begin{tabular}{|c|c|c|c|c|c|c|c|c|c|c|c|c|}
\hline Seg & Taxon & TAXC & NCBI & FG & (for Bl) & Sampler Da & & $B$ & C & D & E & Rel Abd \\
\hline 1 & Stenonema spp. & EP & 3.4 & Sc & 1094.8 & & 60 & 53 & 47 & 79 & 77 & 32.00795 \\
\hline 2 & Cricotopus/Ortho spp. & DOR & 8.8 & CG & 959.2 & & 32 & 28 & 35 & 12 & 2 & 10.83499 \\
\hline 3 & Macronychus glabratus & $\mathrm{Co}$ & 4.7 & CG & 404.2 & & 10 & 13 & 19 & 24 & 20 & 8.548708 \\
\hline 4 & Thienemanniella spp. & DOR & $\underline{6}$ & CG & 438 & & 7 & 13 & 6 & 39 & 8 & 7.256461 \\
\hline 5 & Pentaneura inconspicua & DTA & 4.6 & $\mathbf{P}$ & 262.2 & & 18 & 7 & 17 & 7. & 8 & 5.666004 \\
\hline & Oecatis spp. & TR & 5.7 & P & 290.7 & & 6) & 5 & 11 & 19 & 10 & 5.089583 \\
\hline
\end{tabular}




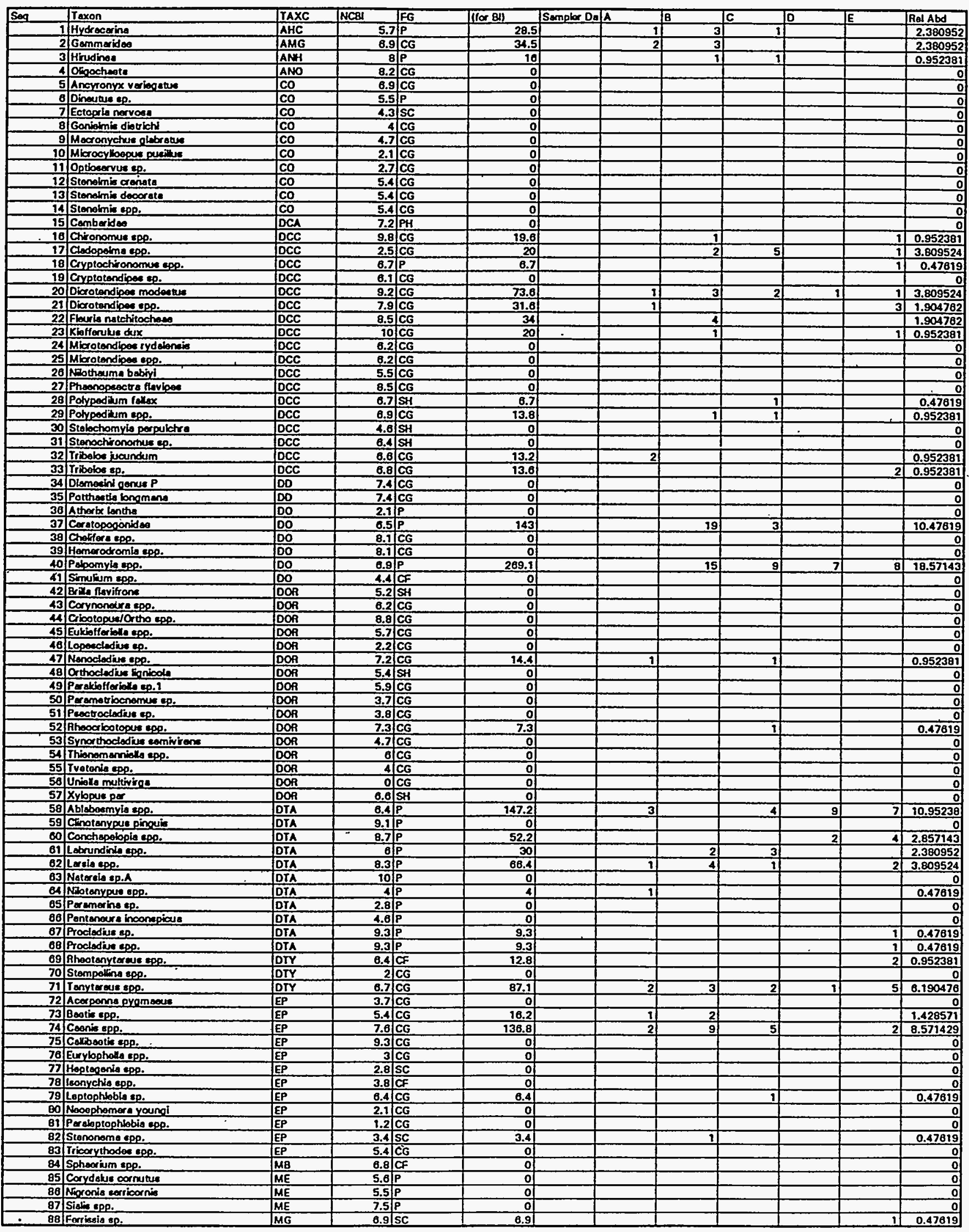




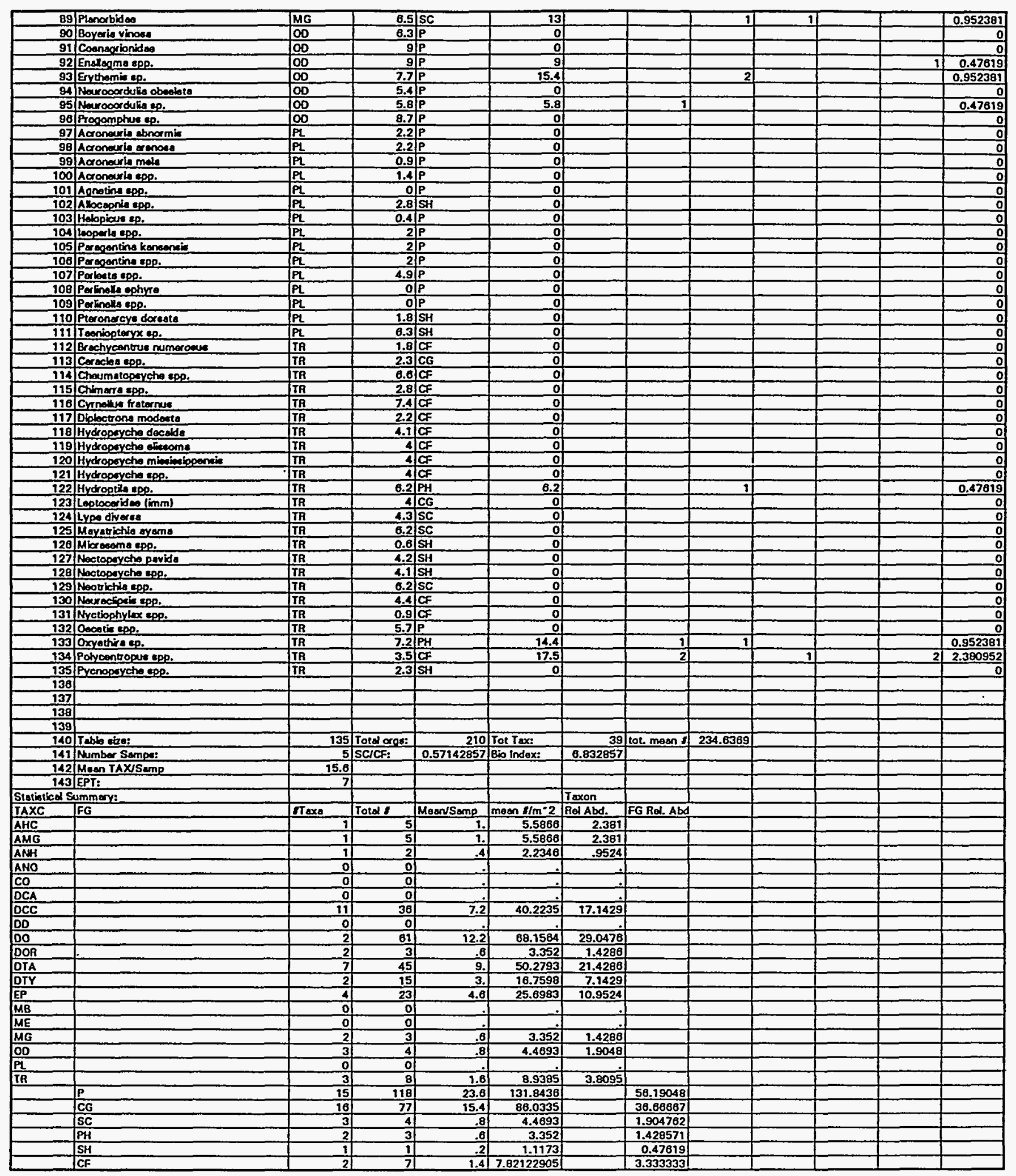




\begin{tabular}{|l|}
\hline Taxa List: \\
\hline Hydracarina \\
\hline Gammaridae \\
\hline Hirudinea \\
\hline Chironomus spp. \\
\hline Cladopelma spp. \\
\hline Cryptochironomus spp. \\
\hline Dicrotendipes modestus \\
\hline Dicrotendipes spp. \\
\hline Fleuria natchitocheae \\
\hline Kiefferulus dux \\
\hline Polypedilum fallax \\
\hline Polypedilum spp. \\
\hline Tribelos jucundum \\
\hline Tribelos sp. \\
\hline Ceratopogonidae \\
\hline Palpomyia spp. \\
\hline Nanocladius spp. \\
\hline Rheocricotopus spp. \\
\hline Ablabesmyia spp. \\
\hline Conchapelopia spp. \\
\hline Labrundinia spp. \\
\hline Larsia spp. \\
\hline Nilotanypus spp. \\
\hline Procladius sp. \\
\hline Procladius spp. \\
\hline Rheotanytarsus spp. \\
\hline Tanytarsus spp. \\
\hline Baetis spp. \\
\hline Caenis spp. \\
\hline Leptophlebia sp. \\
\hline Stenonema spp. \\
\hline Ferrissia sp. \\
\hline Planorbidae \\
\hline Enallagma spp. \\
\hline Erythemis sp. \\
\hline Heurocordulia sp. \\
\hline Polila spp. \\
\hline
\end{tabular}


UNNAMED TRIB. OF STEEL CREEK @ RD 125 08/19/93 STATION 29

\begin{tabular}{|c|c|c|c|c|c|c|c|c|c|c|c|}
\hline Sog & Taxon & TAXC & $\mathrm{NCBI}$ & $F G$ & (for Bl) & Sampler Da A & $B$ & TC & $D$ & $E$ & Rel Abd \\
\hline 1 & Palpomyia spp. & 100 & 6.9 & $\mathbf{P}$ & 269.1 & & 15 & \begin{tabular}{l|l}
9 \\
\end{tabular} & 7 & 8 & 18.57143 \\
\hline 2 & Ablabesmyia spp. & DTA & 6.4 & P & 147.2 & 3 & & 4) & 9 & 7 & 10.95238 \\
\hline 3 & Ceratopogonidae & DO & 6.5 & $P$ & 143 & & 19 & 3 & & & 10.47619 \\
\hline 4 & Caenis spp. & EP & 7.6 & $C G$ & 136.8 & 2 & 9 & 5 & & 2 & 8.571429 \\
\hline & Tanytarsus spp. & DTY & 6.7 & CG & 87.1 & 2 & 3 & 2 & 1 & 5 & 6.190476 \\
\hline
\end{tabular}




\begin{tabular}{|c|c|c|c|c|c|c|c|c|c|}
\hline $\operatorname{sog}$ & Taxan & TAXC & NCA & FG & (for $B\}$ & Sempler $\mathrm{DA}$ & $\mathbf{A}$ & 18 & C. \\
\hline & Hydecering & AHC & 5.7 & & 39.9 & & 3 & 1 & \\
\hline 2 & Gemmerides & AMG & 8.9 & $\mathbf{C G}$ & 0 & & & & \\
\hline 3 & Oripochente & ANO & $B .2$ & CG & 可 & & & & \\
\hline & A Anopronyx verlogatue & Co & $8.9 \mathrm{c}$ & CG & of & & & & \\
\hline & 5 Dinoutare sp. & Co & $5.5 \mathrm{~F}$ & & a & & & & \\
\hline & 9 Eetopio nervoces & Co & 4.35 & SC & a & & & & \\
\hline & 7 Goniolmis diatrichi & Co & 40 & CG & of & & & & \\
\hline 8 & Mecronychue globresuse & co & 4.710 & CG & 98.7 & & of & 5 & 7 \\
\hline & Mlaogyloopue puritus & co & $2.1 \bar{c}$ & $\overline{G G}$ & of & & & & \\
\hline 10 & Optocenves ep. & co & 2.710 & CG & of & & & & \\
\hline 11 & Stondmis crenata & $\mathrm{co}$ & 5.40 & CG & of & & & & \\
\hline 12 & Stanolmis aronata & co & $5.4 . \mathrm{C}$ & CG & 5.4 & & & & It \\
\hline 13 & Stonotmir decorata & co & $5.4 . \mathrm{c}$ & CG & of & & & & \\
\hline 14 & Comberides & DCA & \begin{tabular}{l|l}
7.2 & $P$ \\
\end{tabular} & PH & of & & & & \\
\hline 15 & Cryptochironomue epp. & DCC & $6.7 / \mathrm{P}$ & $\mathbf{P}$ & of & & & & \\
\hline 18 & Cryptotondipen ep. & DCC & 8.110 & CG & of & & & & \\
\hline in & Dicrotendipos modesures & DCC & $9.21 \mathrm{c}$ & CG & of & & & & \\
\hline 18 & Dlarotondipes noomodereus: & DCC & 8.30 & CG & of & & & & \\
\hline 10 & Dicrotendipos epp. & DCC & $7.9 \mathrm{c}$ & CG & of & & & & \\
\hline 20 & Mkarotondipen rydelonsis & DCC & $0.21 \mathrm{c}$ & CG & of & & & & \\
\hline 21 & Mlacotondipen epp. & JOCC & $8.21 \mathrm{C}$ & CG & of & & & & \\
\hline 22 & Notherma bobiyl & DCC & $5.5 \mathrm{C}$ & CG & of & & & & \\
\hline 23 & Ptheonopecectra flaripen & DCC & $8.57 \mathrm{C}$ & CG & of & & & & \\
\hline 24 & Polypodium fellex & DCCE & 6.7.5 & SH & 13.4 & & & & 1 \\
\hline 25 & Pobypedium spp. & DCC & $0.9 \mathrm{c}$ & CG & 588.5 & & 35 & 14 & 10 \\
\hline 20 & Stolachom yia perpeskchra & DCC & 4.65 & $\mathrm{SH}$ & of & & & & \\
\hline 27 & Slonochironomuse. ep. & DCC & 0.45 & SH & 83.2 & & (4) & 4 & 2 \\
\hline 28 & Iribotos huoundum & DCC & $0.6 \mathrm{C}$ & CG & of & & & & \\
\hline 29 & ADterneoin penus $P$ & $D D$ & $7.41 c$ & CG & of & & & & \\
\hline 30 & Potthertis bongmene & Do & $7.4 \mathrm{c}$ & GG & of & & & & \\
\hline 31 & Atterbx lentho & DO & $2.1 / \mathrm{p}$ & & af & & & & \\
\hline 32 & Coratopoganideo & 100 & $6.5 \mathrm{P}$ & & af & & & & \\
\hline 33 & Cheffera spp. & DO & $8.1 \mathrm{C}$ & CG & of & & & & \\
\hline 34 & Hemerodromis app. & DO & $8.1 \mathrm{C}$ & CG & 153.9 & & 3 & ] & 3 \\
\hline 35 & Pabonyia spp. & DO & $8.97 \mathrm{P}$ & & of & & & & \\
\hline 36 & Simuleum epp. & Doo & $4.4 \mathrm{C}$ & CF & 4.4 & & & & 1 \\
\hline 37 & Bilta flevifions & DOR & 5.25 & SH & of & & & & T \\
\hline 38 & Corynoneura spp. & DOR & $6.2 / C$ & CG & 80.8 & & 5 & 2 & 5 \\
\hline 39 & Crioolopou/ or tho epp. & DOR & $8.8 \mid \bar{C}$ & CG & 248.4 & & 6) & 4 & (3) \\
\hline 40 & Eukiafferialle spp. & DOR & $5.7] \mathrm{C}$ & CG & of & & & & \\
\hline 41 & Loposctodius ep. & DOR & $2.2 \mathrm{C}$ & CG & of & & & & \\
\hline 42 & Nenocladius upp. & DOR & $7.21 \mathrm{C}$ & CG & 0 & & & & \\
\hline 43 & Orthocladius Egnioola & DOR & $5.4 \mid \mathrm{S}$ & SH & of & & & & \\
\hline 44 & Perekiofforballa co. 1 & DOA & $5.91 \mathrm{C}$ & CG & of & & & & \\
\hline 45 & Pesemeriocnemun sp. & DOR & $3.7 \mid \mathrm{C}$ & $\mathbf{C G}$ & 3.7 & & & 1] & \\
\hline 48 & Peactroclodive sp. & DOR & $3.8 / \mathrm{C}$ & CG & of & & & & \\
\hline 47 & fihoocrioplopule epp. & DOP & $7.3 \mathrm{c}$ & CG & 788.5 & & 13 & 24 & 12 \\
\hline 48 & Synorthoctodius comivitens & DOR & $4.71 \mathrm{C}$ & CG & of & & & & \\
\hline (9) & Thionomenniolla spp. & DOA & $8 / c$ & CG & 2274 & & 55 & 103 & 54 \\
\hline 50 & Tvatonis ope. & DOR & \begin{tabular}{l|l}
4 \\
\end{tabular} & CG & 8 & & 1 & & \\
\hline 51 & Uniolle multivirga & DOR & & CG & of & & & & \\
\hline 52 & xylopese per & DOA & 8.65 & SH & of & & & & \\
\hline 53 & Ablaboosmyia app. & DTA & $8.4 \mathrm{P}$ & $\mathbf{P}$ & 19.2 & & & 21 & \\
\hline 54 & Cinotomypue pinguis & DTA & 9.1) $\bar{P}$ & $\mathbf{P}$ & of & & & & \\
\hline 55 & Conchspotopia spp. & DTA & $\left.8.7\right|_{P}$ & $\mathbf{P}$ & of & & & & \\
\hline 56 & Lebrundinia epp. & DTA & $6 / 9$ & $P$ & of & & & & \\
\hline 57 & Natersis Bp.A & DTA & $10 T$ & $\mathbf{P}$ & of & & & & \\
\hline 58 & NFotomypue Epp. & OTA & $4 / \bar{P}$ & $\mathbf{P}$ & 4 & & & & 1 \\
\hline 59 & Peramerina ep. & DTA & $2.8 \mid \mathrm{P}$ & $\mathbf{P}$ & of & & & & \\
\hline 80 & Pentenarrs hoonepious & DTA & $4.6) \mathrm{P}$ & $\mathbf{P}$ & of & & & & \\
\hline 61) & Proclodive sp. & DrA & $9.3 \mathrm{P}$ & $\mathrm{P}$ & of & & & & \\
\hline 62 & Rhootanyiercus spp. & DTY & $0.4]$ & $C F$ & 1075.2 & & 35 & 18 & 44 \\
\hline 63 & Stempoltipe sop. & $\mathrm{DTY}$ & & $\overline{\mathbf{C G}}$ & of & & & & \\
\hline 84 & Tanyiereus epp. & DTY & $\begin{array}{c}0.7 \\
\end{array}$ & CG & 13.4 & & 2 & & \\
\hline 65 & Acosponna pyemoous & EP & $\begin{array}{l}3.7 \\
\end{array}$ & CG & a & & & & \\
\hline 66 & Boolis spp. & $E P$ & $5.4 \mathrm{c}$ & CG & 129.6 & & 2 & 2 & 4 \\
\hline 67 & Coonis epp. & EP & $7.6 / \mathrm{C}$ & CG & of & & & & \\
\hline 68 & Calliboetis Epp. & $E P$ & $9.3 \mathrm{C}$ & CG & of & & & & \\
\hline 69 & Ephemeroto sp. & EP & $1.4 \mathrm{C}$ & CG & 2.8 & & & & \\
\hline 70 & Eurylopholle spp. & EP & $3 \mathrm{c}$ & CG & 0 & & & & \\
\hline 711 & Hoptogonia epp. & EP & 2.85 & $s c$ & of & & & & \\
\hline 72 & Leonychio epp. & EP & $3.8 \mathrm{C}$ & CF & of & & & & \\
\hline 73 & Nooophemere youngl & EP & $2.1 \mathrm{C}$ & CG & of & & & & \\
\hline 74 & Proboplophiobia spp. & EP & $1.2 \mathrm{C}$ & CG & of & & & & \\
\hline 75 & Stononome spp. & EP & $\begin{array}{ll}3.45 \mathrm{~S} \\
\end{array}$ & Sc & 550.8 & & 26 & 25 & 33 \\
\hline 70 & Tricorythodes spe. & EP & $5.4 \mathrm{C}$ & CG & 27 & & i) & & i) \\
\hline 77 & Sphoorium spp. & $M B$ & $7.7 / \mathrm{C}$ & CF & 0 & & & & \\
\hline 78 & Coryd shes correutus & ME & $5.8 / \mathrm{P}$ & $\bar{P}$ & 145.6 & & 8] & 7 & 5 \\
\hline 791 & Nopronis serricornis & ME & $5.5 / \mathrm{P}$ & & 16.5 & & & & I) \\
\hline 801 & Siarts spp. & ME & $7.5 \mid \mathrm{P}$ & & of & & & & \\
\hline 811 & Forrisalia sp. & MG & $0.9 / 5$ & SC & of & & & & \\
\hline 82 & Boyorla vinoes & 00 & $0.3 / \mathrm{P}$ & & of & & & & \\
\hline 83 & Conongrionid es & OD & $g \mid p$ & & of & & & & \\
\hline$B 4$ & Enollogmo spp. & OO & $9 / p$ & $\mathbf{P}$ & of & & & & \\
\hline 85 & Neurocordutio obselata & OD & $5.4 / \mathrm{P}$ & & of & & & & \\
\hline 68) & Progomphus sp. & 00 & $8.7 \mid \mathrm{P}$ & & of & & & & \\
\hline 87 & Acronouris abnormis & $P L$ & $2.2 P$ & & of & & & & \\
\hline 88] & Acromaurio aronoss & $P$ & $2.21 \mathrm{P}$ & P & of & & & & \\
\hline
\end{tabular}




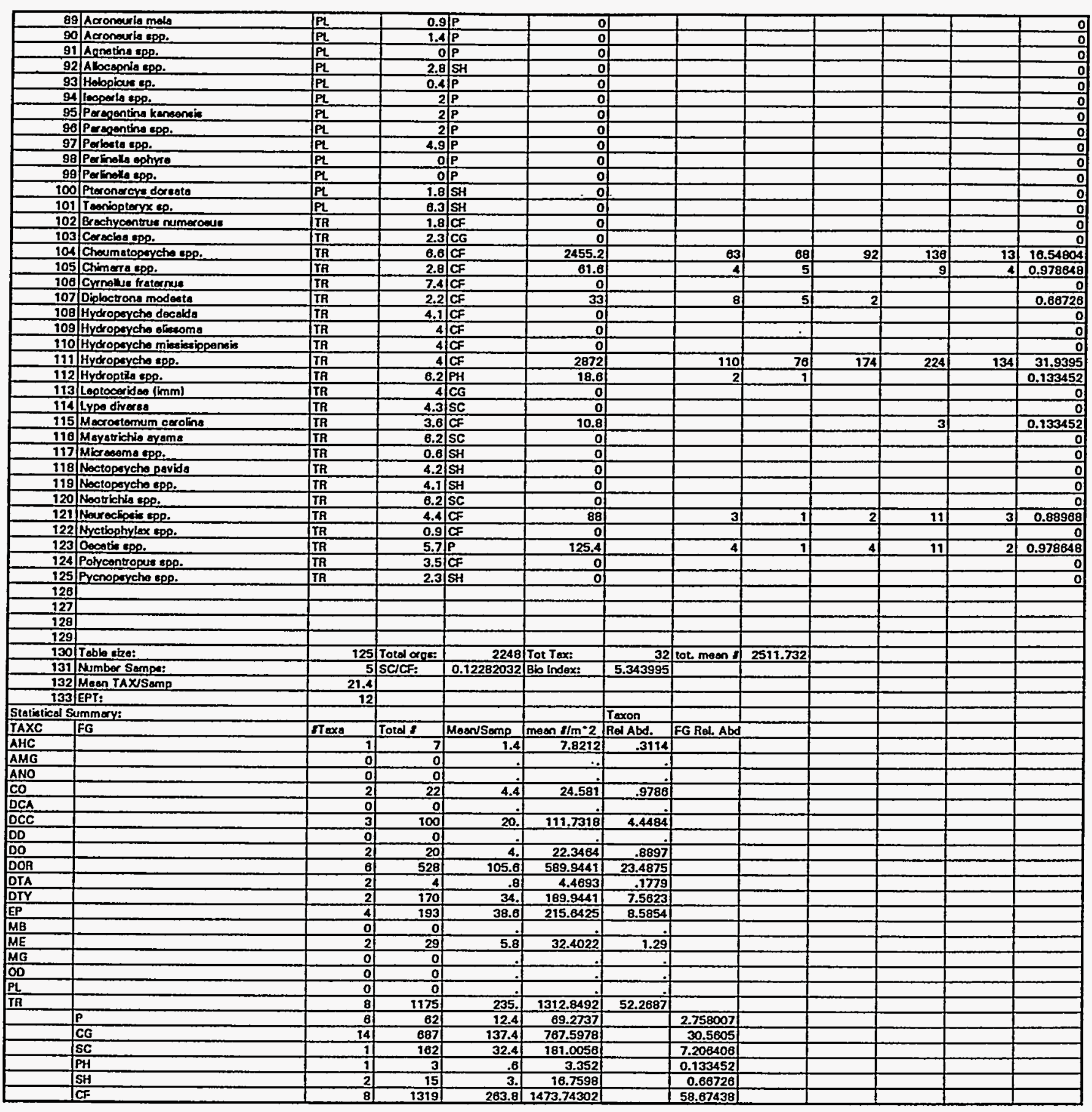




\begin{tabular}{|l|}
\hline Taxa List: \\
\hline Hydracarina \\
\hline Macronychus glabratus \\
\hline Stenelmis crenata \\
\hline Polypedilum fallax \\
\hline Polypedilum spp. \\
\hline Stenochironomus sp. \\
\hline Hemerodromia spp. \\
\hline Simulium spp. \\
\hline Corynoneura spp. \\
\hline Cricotopus/Ortho spp. \\
\hline Parametriocnemus sp. \\
\hline Rheocricotopus spp. \\
\hline Thienemanniella spp. \\
\hline Tvetenia spp. \\
\hline Ablabesmyia spp. \\
\hline Nilotanypus spp. \\
\hline Rheotanytarsus spp. \\
\hline Tanytarsus spp. \\
\hline Baetis spp. \\
\hline Ephemerella sp. \\
\hline Stenonema spp. \\
\hline Tricorythodes spp. \\
\hline Corydalus cornutus \\
\hline Nigronia serricornis \\
\hline Cheumatopsyche spp. \\
\hline Chimarra spp. \\
\hline Diplectrona modesta \\
\hline Hydropsyche spp. \\
\hline Hydroptila spp. \\
\hline Macrostemum carolina \\
\hline Neureclipsis spp. \\
\hline Oecetis spp. \\
\hline
\end{tabular}




\begin{tabular}{|c|c|c|c|c|c|c|c|c|c|c|c|}
\hline Seq & Taxon & TAXC & NCB! & FG & (for Bl) & Sampler Da $\mathbf{A}$ & $\mathbf{B}$ & $C$ & D & $E$ & Rel Abd \\
\hline & Hydropsyche spp. & TR & & CF & 2872 & 110 & 78 & 174 & 224 & 134 & 31.9395 \\
\hline 2 & Thienemanniella spp. & DOR & & CG & 2274 & 55 & 103 & 54 & 131 & 36 & 16.85943 \\
\hline 3 & Cheumatopsyche spp. & TR & 6.6 & CF & $\begin{array}{l}\text {. } 2455.2 \\
\end{array}$ & 63 & 08 & 92 & 138 & 13 & 16.54804 \\
\hline 4 & Rheotanytarsus spp. & DTY & 6.4 & CF & 1075.2 & 35 & 18 & 44) & 24 & 47 & 7.47331 \\
\hline & Stenonema spp. & EP & 3.4 & SC & 550.8 & 26 & 25 & 33 & 64 & 14 & 7.206406 \\
\hline
\end{tabular}




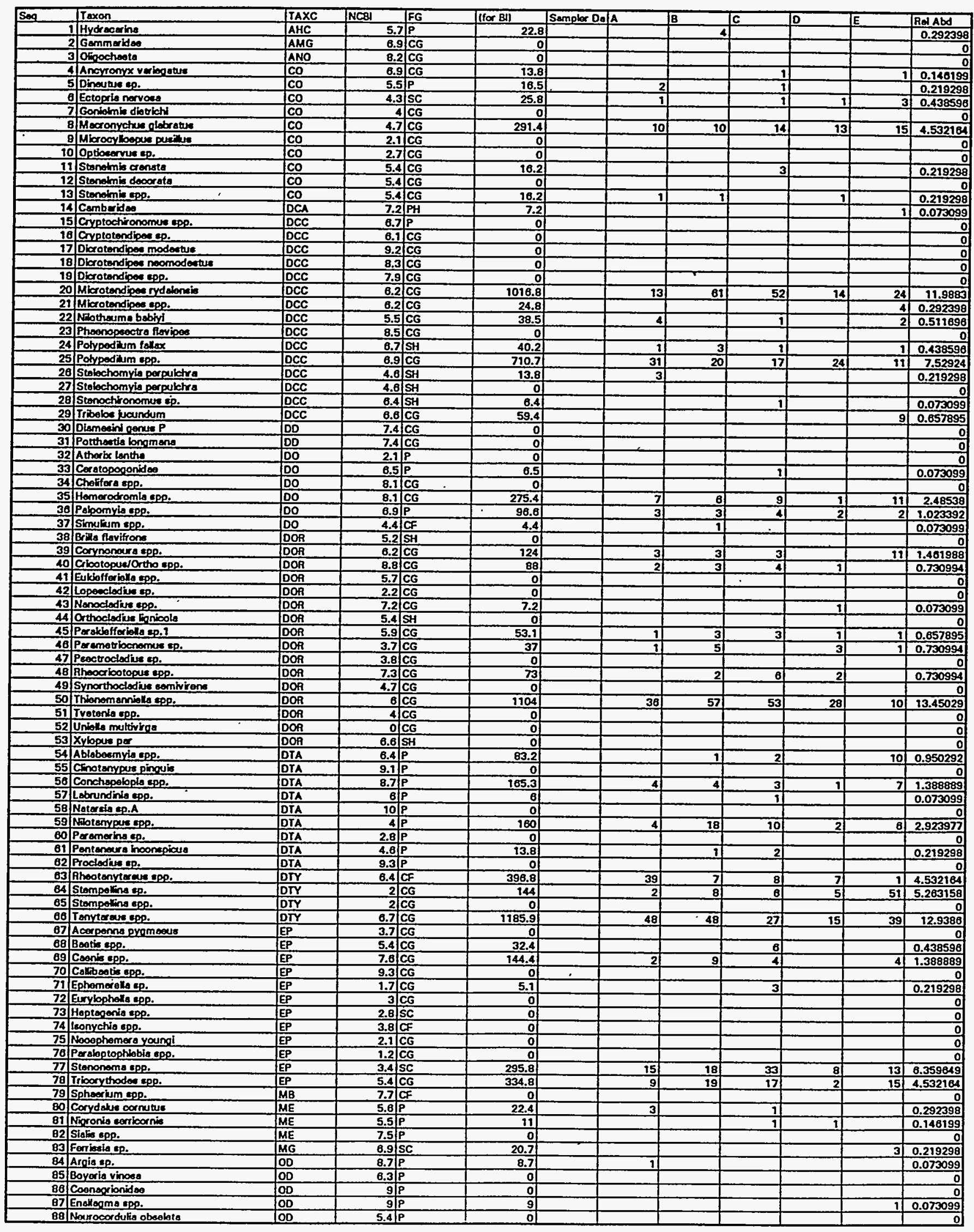




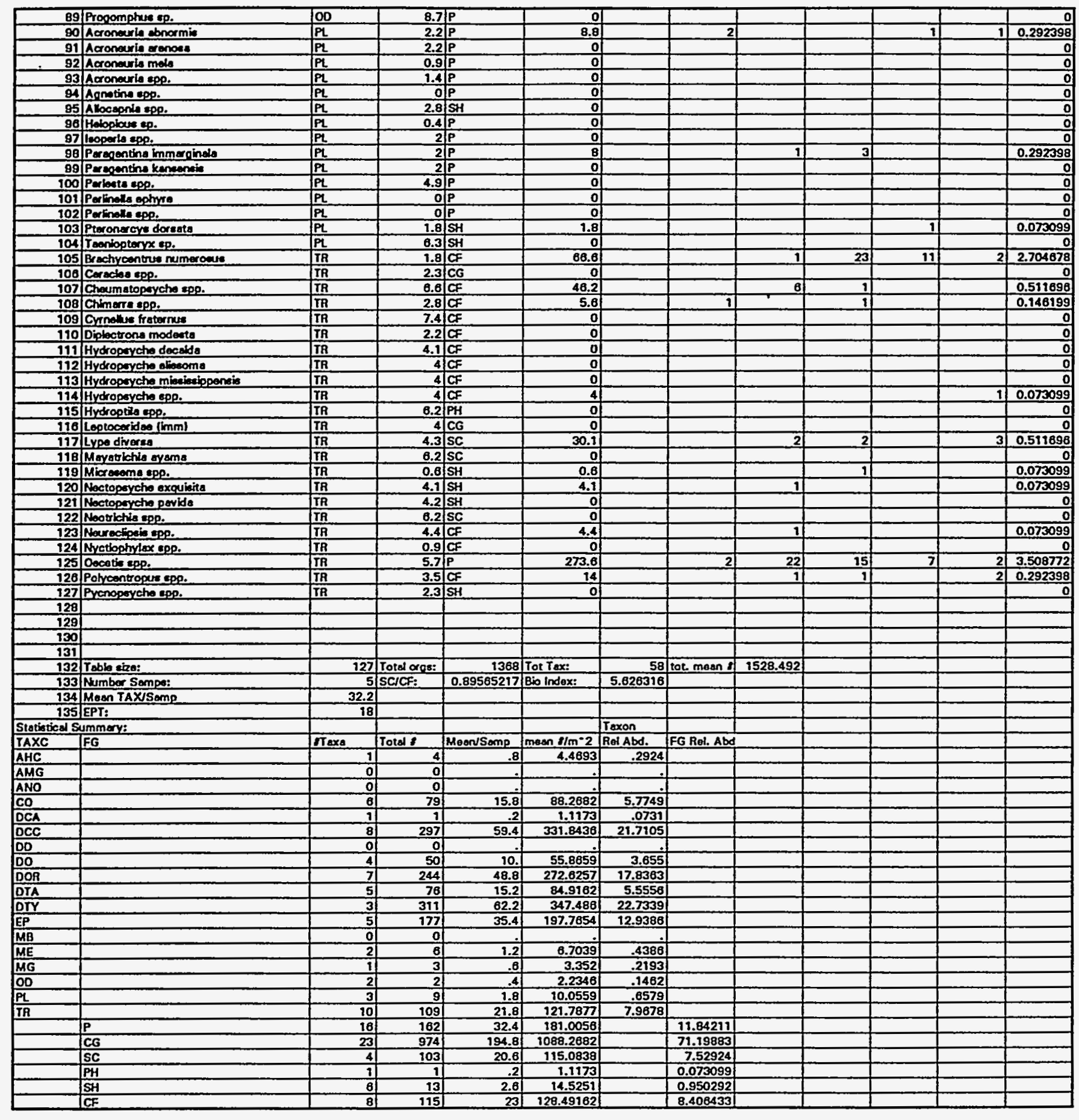


LTR PATTERSON MILL RD. 08/19/93 STATION 31

\begin{tabular}{|l|}
\hline Taxa List: \\
\hline Hydracarina \\
\hline Ancyronyx variegatus \\
\hline Dineutus sp. \\
\hline Ectopria nervosa \\
\hline Macronychus glabratus \\
\hline Stenelmis crenata \\
\hline Stenelmis spp. \\
\hline Cambaridae \\
\hline Microtendipes rydalensis \\
\hline Microtendipes spp. \\
\hline Nilothauma babiyi \\
\hline Polypedilum fallax \\
\hline Polypedilum spp. \\
\hline Stelechomyia perpulchra \\
\hline Stenochironomus sp. \\
\hline Tribelos jucundum \\
\hline Ceratopogonidae \\
\hline Hemerodromia spp. \\
\hline Palpomyia spp. \\
\hline Simulium spp. \\
\hline Corynoneura spp. \\
\hline Cricotopus/Ortho spp. \\
\hline Nanocladius spp. \\
\hline Parakiefferiella sp.1 \\
\hline Parametriocnemus sp. \\
\hline Rheocricotopus spp. \\
\hline Thienemanniella spp. \\
\hline Ablabesmyia spp. \\
\hline Conchapelopia spp. \\
\hline Labrundinia spp. \\
\hline Nilotanypus spp. \\
\hline Pentaneura inconspicua \\
\hline Rheotanytarsus spp. \\
\hline Stempellina sp. \\
\hline Tanytarsus spp. \\
\hline Baetis spp. \\
\hline Caenis spp. \\
\hline Ephemerella sp. \\
\hline Stenonema spp. \\
\hline Tricorythodes spp. \\
\hline Corydalus cornutus \\
\hline Nigronia serricornis \\
\hline Ferrissia sp. \\
\hline Argia sp. \\
\hline Enallagma spp. \\
\hline Acroneuria abnormis \\
\hline Paragentina immarginala \\
\hline Pteronarcys dorsata \\
\hline
\end{tabular}


LTR PATTERSON MILL RD. 08/19/93 STATION 31

Brachycentrus numerosus

Cheumatopsyche spp.

Chimarra spp.

Hydropsyche spp.

Lype diversa

Micrasema spp.

Nectopsyche exquisita

Neureclipsis spp.

Oecetis spp.

Polycentropus spp. 


\begin{tabular}{|c|c|c|c|c|c|c|c|c|c|c|c|}
\hline Seq & Taxon & TAXC & NCBI & FG & (for BI) & \begin{tabular}{|l|l|} 
Sampler Da & A \\
\end{tabular} & $B$ & C & $D$ & $E$ & Rel Abd \\
\hline & Thienemanniella spp. & DOR & & CG & 1104 & 36 & 57 & 53 & 28 & 10 & 13.45029 \\
\hline 2 & Tanytarsus spp. & DTY & 6.7 & CG & 1185.9 & 48 & 48 & 27 & 15 & 39 & 12.9386 \\
\hline 3 & Microtendipes rydalensis & DCC & 6.2 & CG & 1016.8 & 13 & 81 & 52 & 14 & 24 & 11.9883 \\
\hline 4 & Polypedilum spp. & DCC & 6.9 & CG & 710.7 & 31 & 20 & 17 & 24 & 11 & 7.52924 \\
\hline 5 & Stenonema spp. & EP & 3.4 & $S C$ & 295.8 & 15 & 18 & 33 & 8 & 13 & 6.359649 \\
\hline & Stempellina sp. & DTY & & CG & 144 & 2 & 8 & 8 & 5 & 51 & 5.263158 \\
\hline
\end{tabular}




\begin{tabular}{|c|c|c|c|c|c|c|c|c|c|}
\hline Seq & Taxon & TAXC & NCB & FG & (for Ban) & Sompler Dal & A & B & C \\
\hline 1 & Hydrecerins & AHC & 5.7 & P & 5.7 & & & & \\
\hline 2 & 2 Gonmeridien & AMG & 0.9 & CG & of & & & & \\
\hline 3 & Ofoochente & ANO & 8.2 & CG & of & & & & \\
\hline 4 & Aneromy $x$ veriogatue & co & 6.9 & CG & 13.8 & & & & \\
\hline $\mathbf{5}$ & Dinceutusep. & co & 5.5 & $P$ & 5.5 & & & & 1 \\
\hline 6 & Dubirephia ep. & co & 6.4 & CG & 12.8 & & & & 2 \\
\hline$\overline{7}$ & Eotopris nervosa & co & 4.3 & sc & of & & & & - \\
\hline 8 & Gonivimis diotrichi & Co & 4 & CG & of & & & & \\
\hline 9 & Mecromychue olabrature & $\mathrm{CO}$ & 4.7 & CG & 01.1 & & 1 & 2 & 6) \\
\hline 10 & I Miorocy lospus pueilie & co & 2.1 & CG & of & & & & \\
\hline 11 & Opoionervue ip. & Co & 2.7 & CG & of & & & & \\
\hline 12 & Stenoimin crenste & Co & 5.4 & CG & 54 & & 2 & 4 & \\
\hline 13 & Stenolinis decorata & $\mathrm{CO}$ & 5.4 & CG & of & & & & \\
\hline 14 & IStendmin sop. & $\mathrm{CO}$ & 5.4 & CG & of & & & & \\
\hline 15 & Cemberides & DCA & 7.2 & $P H$ & of & & & & \\
\hline 10 & Cryptochionomurepp. & DCC & 6.7 & $P$ & of & & & & \\
\hline 17 & Cryptotendipeses. & DCC & 6.1 & CG & of & & & & \\
\hline 18 & Dicrotendipes modectus & DCC & 9.2 & CG & of & & & & \\
\hline 19 & Diorotendipes neomodecture & DCc & 8.3 & CG & of & & & & \\
\hline 20 & Dicrotandionespe. & DCC & 7.9 & CG & of & & & & \\
\hline 21 & Microtendipes rydaloneis & DCC & 6.2 & CG & of & & & & \\
\hline 22 & Microtendipes epg. & DCC & 6.2 & CG & of & & & & \\
\hline 23 & Nethouma bebiy? & DCC & 5.5 & CG & of & & & & \\
\hline 24 & I Phoenopeectro flovipes & DCC & 8.5 & CG & of & & & & \\
\hline 25 & Polypedinim follox & DCc & 8.7 & $\mathrm{SH}$ & 6.7 & & & & \\
\hline 28 & Polypedum spo. & DCC & 6.9 & CG & 841.8 & & & 9 & 49 \\
\hline 27 & Steloctiom yia perpitktra & DCC & 4.8 & SWH & 9.2 & & & & 1 \\
\hline 28 & Stenoctironomuse ep. & DCC & 6.4 & SH & 12.8 & & & & \\
\hline 29 & Tribolon juandum & DCC & 6.6 & CG & of & & & & \\
\hline 30 & Diemenini genuse $P$ & DD & 7.4 & CG & a & & & & \\
\hline 31 & Porthestia longmens & DD & 7.4 & CG & o) & & & & \\
\hline 32 & Atherix lentio & DO & 2.1 & $\bar{P}$ & 6.3 & & & 2 & \\
\hline 33 & Coratopoponideo & Do & 6.5 & $P$ & 0 & & & & \\
\hline 34 & Cholftera cpp. & Do & 8.1 & CG & of & & & & \\
\hline 35 & Hemeradromle spp. & 100 & 8.1 & CG & 137.7 & & i) & 2 & 5 \\
\hline 30 & Pespomyis epp. & DO & 6.9 & P & 13.8 & & & & 1 \\
\hline 37 & Simusum cop. & DO & 4.4 & CF & 338.8 & & 1 & 24 & 7 \\
\hline 38 & HBrila fievifrons & DOA & 5.2 & SH & of & & & & \\
\hline 39 & Corynonoura spp. & DOA & 6.2 & CG & 12.4 & & & & \\
\hline 40 & Cricotopulartho cpe. & DOA & 8.8 & CG & 3634.4 & & 11 & 192 & 103 \\
\hline 41 & Euktiofferiale app. & DOR & 5.7 & CG & of & & & & \\
\hline 42. & Lopancladiuse es. & DOR & 2.21 & CG & of & & & & \\
\hline 43 & Nonoclediue epo. & DOR & 7.2 & CG & 93.6 & & & 1 & 7 \\
\hline 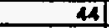 & Orthocladiue fignicola & DOR & 5.4 & SH & of & & & & \\
\hline 45 & Perakiafferials ep.1 & DOR & 5.9 & CG & 11.8 & & & 4 & \\
\hline 16 & Paramotiocnemue sp. & DOR & 3.7 & CG & 77.7 & & 1 & 1 & 8 \\
\hline 47 & Pacetrocladiu sp. & DOR & 3.8 & $\mathbf{C G}$ & 0 & & & & \\
\hline 48 & Ahoocticotopus spe. & DOR & 7.3 & CG & 649.7 & & 2 & 10 & 32 \\
\hline 49 & Synonthoded tue semivirons & DOR & 4.7 & CG & 28.2 & & & .1 & 1 \\
\hline 50 & Thionomanniolaspe. & TDOR & e & CG & 834 & & 1 & 21 & 61) \\
\hline 51 & Trotonia epp. & DOR & 4 & CG & 72 & & & 2 & 1 \\
\hline 52 & Unialle multivitgo & DOA & of & CG & of & & & & \\
\hline 53 & Xyiopus per & DOA & 6.6 & $\mathrm{SH}$ & 0 & & & & \\
\hline 54 & Ablaboemyia spp. & TOTA & 6.4 & $\mathbf{P}$ & of & & & & \\
\hline 55 & Cinotonypue pinquie & DTA & 9.1 & $\mathbf{P}$ & 0 & & & & \\
\hline 56 & Conchrepolopis spp. & DTA & 8.7 & $P$ & 182.7 & & & & 8) \\
\hline 57 & Lobrundiris epp. & DTA & ef & $P$ & of & & & & \\
\hline 58 & Natreis gp, A & DTA & 10 & $P$ & of & & & & \\
\hline 59 & NEbtenypue spp. & DTA & 4 & $P$ & 0 & & & & \\
\hline$\infty$ & Peremerina ep. & DTA & 2.8 & $\mathbf{P}$ & a & & & & \\
\hline 61 & Pontoncura lnoonipicus & DTA & 4.6 & $\mathbf{P}$ & of & & & & \\
\hline 62 & Proctadius sp. & DTA & 9.3 & $\mathbf{P}$ & of & & & & \\
\hline 63) & Fhootenyt ereure.spe. & DTY & 0.4 & CF & 224 & & & & II \\
\hline 64 & Stomporina epp. & DrY & 2 & CG & 2 & & & & \\
\hline 85 & Tenytereses app. & DTY & 6.7 & CG & 328.3 & & & & 19 \\
\hline 88 & Acerpenns gyemeous & EP & 3.7 & CG & of & & & & \\
\hline$\theta 7$ & Bootie spp. & EP & 5.4 & CG & 91.8 & & & 21 & 1 \\
\hline 68 & Coenie epp. & EP & 7.8 & CG & 7.6 & & & & \\
\hline 69 & Colphootic epp. & EP & 9.3 & CG & of & & & & \\
\hline 70 & Eurylophale app. & EP & 3 & CG & 0 & & & & \\
\hline 71) & Hoptegente epp. & EP & 2.8 & SC & of & & & & \\
\hline 72 & Ieonychio epp. & EP & 3.8 & CF & of & & & & \\
\hline 73 & Noosphemers youngi & EP & 2.1 & $\mathbf{C G}$ & of & & & & \\
\hline 74 & Paraloptophlobla spp. & EP & 1.2 & $\mathbf{C G}$ & of & & & & \\
\hline 75 & Stononome epp. & EP & 3.4 & SC & 112.2 & & 4 & 4 & 8 \\
\hline 78 & Tricory thodes spp. & EP & 5.4 & CG & 10.8 & & & & 1 \\
\hline 77 & Perspognyx & LEP & 5 & $\mathbf{P H}$ & 10 & & & & \\
\hline 78 & Sphoorium spp. & $M B$ & 7.7 & CF & of & & & & \\
\hline 79 & Coryd deve cornetus & ME & 5.6 & $\mathbf{P}$ & of & & & & \\
\hline 80 & Nioronia serriconnis & ME & $5.5 \mid$ & $\mathbf{P}$ & 5.5 & & & & \\
\hline 81 & Sialie spe. & ME & 7.5 & $\mathbf{P}$ & of & & & & \\
\hline 82 & Forriogia ep. & MG & 0.9 & SC & of & & & & \\
\hline 83 & Boyoria vinoss & OD & 8.3 & $\mathbf{P}$ & 0 & & & & \\
\hline Ba & Coonerionideo & 100 & 91 & $\mathbf{P}$ & o & & & & \\
\hline 85 & Enalkeqma cpp. & $\infty$ & 9 & $P$ & of & & & & \\
\hline 80 & Nourocordulia abealate & OD & $5.4 / 8$ & $p$ & of & & & & \\
\hline 87 & Propomphure & OD & 8.71 & $\mathbf{P}$ & 요 & & & & \\
\hline 88 & Acronourio abnormis & $\overline{P L}$ & 2.211 & $\mathbf{P}$ & 22 & & & 1) & \\
\hline
\end{tabular}


Taxa List:

Hydracarina

Ancyronyx variegatus

Dineutus sp.

Dubiraphia sp.

Macronychus glabratus

Stenelmis crenata

Polypedilum fallax

Polypedilum spp.

Stelechomyia perpulchra

Stenochironomus sp.

Atherix lantha

Hemerodromia spp.

Palpomyia spp.

Simulium spp.

Corynoneura spp.

Cricotopus/Ortho spp.

Nanocladius spp.

Parakiefferiella sp. 1

Parametriocnemus sp.

Rheocricotopus spp.

Synorthocladius semivirens

Thienemanniella spp.

Tvetenia spp.

Conchapelopia spp.

Rheotanytarsus spp.

Stempellina spp.

Tanytarsus spp.

Baetis spp.

Caenis spp.

Stenonema spp.

Tricorythodes spp.

Parapognyx

Nigronia serricornis

Acroneuria abnormis

Paragentina immarginata

Paragentina kansensis

Pteronarcys dorsata

Brachycentrus numerosus

Cheumatopsyche spp.

Chimarra spp.

Hydropsyche spp.

Hydroptila spp.

Lype diversa

Oecetis spp. 
UTR - RR OB/20/93 STATION 32 List of taxa $>5 \%$ relative abundance

\begin{tabular}{|c|c|c|c|c|c|c|c|c|c|c|c|c|}
\hline Seq & Taxon & TAXC & NCBI & FG & (for BI) & Sampler Da & & $\bar{B}$ & C & $D$ & $\mathrm{E}$ & Rol Abd \\
\hline$\overline{1}$ & Cricotopus/Ortho spp. & DOR & 8.8 & CG & 3634.4 & & 11 & 192 & 103 & 40 & 67 & 33.4684 \\
\hline 2 & Thienemanniella spp. & DOR & 6 & CG & 834 & & 1 & 21 & 61 & 21 & 35 & 11.26418 \\
\hline 3 & Polypedilum spp. & $D C C$ & 6.9 & CG & 841.8 & & & 9 & 49 & 35 & 29 & 9.886548 \\
\hline 4 & Rheocricotopus spp. & DOR & 7.3 & CG & 649.7 & & 2 & 10 & 32 & 27 & 18 & 7.212318 \\
\hline & Simúlium spp. & DO & 4.4 & $C F$ & 338.8 & & 1 & 24 & 7 & 3 & 42 & 6.23987 \\
\hline
\end{tabular}




\begin{tabular}{|c|c|c|c|c|c|c|c|c|c|}
\hline Seq. & Toxon & Traxc & NCB & FG & (for B B f & Sampler Da & A & B & C \\
\hline$t$ & Hydrecerine & AHC & 5.7 & $P$ & of & & & & \\
\hline 2 & Gemmerides & AMG & 6.9 & CG & of & & & & \\
\hline 3 & Ofipocheots & ANO & 8.2 & CG & of & & & & \\
\hline 4 & Ancronyx valiogatue & co & 6.9 & CG & 6.9 & & & & \\
\hline 5 & Dinoutusep. & co & 5.5 & $P$ & of & & & & \\
\hline 6 & Duhirephie ep. & $\mathrm{Co}$ & 0.4 & Sc & 12.8 & & 2 & & \\
\hline 7 & Ectoprla nervoes & $\mathrm{Co}$ & 4.3 & SC & of & & 7 & & \\
\hline 8 & Gonimimi diatrich & Co & 4 & CG & 0 & & & & \\
\hline 8 & Mecromrchen olebretere & Co & 4.7 & CG & 108.1 & & 5| & 2 & 2 \\
\hline 10 & Mlorocrlospue pueiline & co & 2.1 & CG & of & & & & \\
\hline 17 & Optiocervive so. & co & 2.7 & CG & of & & & & \\
\hline 12 & Stencimis crenste & co & 5.4 & CG & of & & & & \\
\hline 13 & Stoneinil crenatus & co & 5.4 & CG & 194.4 & & 3 & का & 가 \\
\hline 14 & Stonghin decorate & co & 5.4 & CG & 의 & & & & \\
\hline 15 & Cemberides & DCA & 7.2 & PH & 의 & & & & \\
\hline 10 & Chionormive epp. & DCC & 9.8 & CG & 9.8 & & 1 & & \\
\hline 17. & Cryptochironomive epp. & DCC & 6.7 & $\mathbf{P}$ & of & & & & \\
\hline 18 & Cryptotendipes ep. & DCC & 6.7 & CG & of & & & & \\
\hline 19 & Diorotendipes modecture & DCC & 9.2 & CG & 의 & & & & \\
\hline 20 & Diorocendipen neomodentus: & DCC & 8.3 & CG & of & & & & \\
\hline 21 & Dicrotendipose epp. & DCC: & 7.9 & CG & of & & & & \\
\hline 22 & Microtandipen rydelontis & DCC & 6.2 & CG & of & & & & \\
\hline 23 & Microtendipes spp. & DCC & 6.2 & CG & of & & & & \\
\hline 24 & Alotheums bebiyl & DCC & 5.5 & CG & 5.5 & & & & \\
\hline 25 & Pheonopeoctra flavipes & DCC & 8.5 & CG & of & & & & \\
\hline 26 & Polypeditum follex & DCC & 6.7 & SH & 20.1 & & & & \\
\hline 27 & Polypedtem epp. & DCC & 6.9 & CG & 255.3 & & 5 & 4 & 5 \\
\hline 28 & Stabchomyia perpuletra & DCC & 4.6 & SH & 4.6 & & & 11 & \\
\hline 29 & Stunoctironomeve ep. & DCCC & 6.4 & SH & of & & & & \\
\hline 30 & Tribolos juaundum & Dec & 8.6 & CG & of & & & & \\
\hline 31 & Diemesini genue $P$ & 00 & 7.4 & CG & of & & & & \\
\hline 32 & Potthestia lonomersa & DD & 7.4 & CG & of & & & & \\
\hline 33 & Atherix lenthe & Do & 2.1 & $p$ & 6.3 & & & & \\
\hline 34 & Ceratopoponideo & DO & 6.5 & $\mathrm{P}$ & 0 & & & & \\
\hline 35 & Choffere spe. & DO & 8.1 & CG & of & & & & \\
\hline 30 & Hemerodromla spp. & Do & 8.1 & CG & 145.8 & & 2 & 3 & 4 \\
\hline 37. & Polpomyla spg. & DO & 6.9 & $\mathbf{P}$ & of & & 7 & & \\
\hline 38 & Simuleum spe. & DO & 4.4 & CF & 28.4 & & 2 & 1 & If \\
\hline 39 & Brila flavifrons & DOR & 5.2 & $\mathrm{SH}$ & of & & & & \\
\hline 40 & Corynoneurs upp. & DOA & 6.2 & CG & 12.4 & & & 1 & \\
\hline 41 & Cribotopualortho spip. & DOA & 8.8 & $\mathbf{C G}^{\circ}$ & 184.8 & & 1 & 6) & 2 \\
\hline 42 & Eukiofferibite upp. & DOR & 5.7 & CG & of & & & & 7 \\
\hline 43 & Lopescledius ep. & DOR & 2.2 & CG & o & & & & \\
\hline 44 & Nenoclodius ugp. & DOA & 7.2 & CG & 14.4 & & & 1 & \\
\hline 45 & Orthoclodiue Fonicols & DOR & 5.4 & $\mathrm{SH}$ & 5.4 & & I & 1 & \\
\hline 28 & Peraliafferialle ep.1 & DOR & 5.9 & CG & of & & & & \\
\hline 47. & Peremetriocnemus sp. & DOR & 3.7 & CG & 33.3 & & 3 & & 3| \\
\hline 48 & Peectrocled has sp. & DOA & 3.8 & CG & 3.8 & & 1 & & \\
\hline 49 & Rhooctiootopue spp. & DOR & 7.3 & CG & 452.6 & & 7) & 4 & 20 \\
\hline 50 & Synorthocledive cemivirens & DOR & 4.7 & CG & 14.1 & & & & \\
\hline 51) & Thionornenniolle epp. & DOR & 8) & CG & 188 & & 6) & 6 & \\
\hline 52 & Trutonis spe. & DOR & 4 & CG & 8 & & & 1 & \\
\hline 53 & Uniolla multivirgo & DOR & of & CG & of & & & 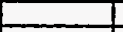 & \\
\hline 54 & Xylopusper & DOR & 6.6. & SH & of & & & & \\
\hline 55 & Abloboesmyia spp. & DIA & 6.4 & $\mathbf{P}$ & 6.4 & & & 1 & \\
\hline 58 & Crinotenypete pinquis & DTA & 9.1 & $P$ & of & & & & \\
\hline 57 & Conchepalopin apg. & TOTA & 8.71 & $P$ & 95.7 & & 1 & 1 & 1 \\
\hline 58 & Labrundinia spe. & OTA & 6 & $P$ & of & & & & \\
\hline 59 & Natereis ep.A & DTA & $10 / 5$ & $\mathbf{P}$ & of & & & & \\
\hline 60) & Niotonypus app. & OTA & $4 F$ & $P$ & 8 & & & & it \\
\hline 61 & Peramerina ep. & DTA & 2.8 & $P$ & of & & & & \\
\hline 62 & Pentanoura inconspicusa & DTA & $4.61 \mathrm{~F}$ & $\mathrm{P}$ & 아 & & & & \\
\hline 63 & Procladius sp. & DTA & $9.3 \mathrm{f}$ & $\mathrm{P}$ & 9.3 & & 1) & & \\
\hline 64) & Ahootanyterese cpg. & DTY & 6.4 C & CF & 102.4 & & 3) & 1. & 4 \\
\hline 65) & Stampelina spg. & DTY & 21 & CG & of & & I & & -1 \\
\hline e8 & Tonytareve spp. & DTY & 6.7 & CG & 127.3 & & 5 & \begin{tabular}{l|l}
3 \\
\end{tabular} & $4 \mid$ \\
\hline 67 & Acorponns pyomoeus & EP & 3.7 & CG & of & & & & \\
\hline 68 & Bootis spp. & EPP & 5.4. & CG & 10.8 & & & & \\
\hline 69 & Coonis spp. & EP & 7.6 & CG & 의 & & & & \\
\hline 70 & Collbootis spp. & EP & 9.3 & CG & of & & & & \\
\hline 71 & Eurybophate epp. & EP & 31 & $\mathbf{C G}$ & of & & & & \\
\hline 72 & Hoptenenia spp. & EP & 2.8 & SG & of & & & & \\
\hline 73 & leonychio epp. & EP & 3.8 & CF & af & & & & \\
\hline 74 & Noopphomera yound & EP & 2.11 & CG & of & & & & \\
\hline 75 & Paraloptophiobia app. & EP & 1.2 & CG & of & & & & \\
\hline 76| & Stenonema epp. & EP & 3.45 & SC & 95.2 & & 4 & & 5| \\
\hline 77 & Tricorythodes spp. & EP & 5.45 & CG & 16.2 & & & & \\
\hline 78 & Sphoerium spp. & $M B$ & 7.71 & $C F$ & of & & & & \\
\hline 79 & Corydakus cornutue & ME & $5.6 / 8$ & $P$ & 5.8 & & & & \\
\hline 80 & Noronia eerricornis & ME & 5.5|p & $\mathbf{P}$ & 5.5 & & 1 & & \\
\hline 81 & Stalis spp. & ME & $7.5 \mathrm{~F}$ & $\mathbf{P}$ & of & & & & \\
\hline 82 & Ferriesia sp. & MG & 8.95 & SC & 0 & & & & \\
\hline 83 & Boyerio vinosa & 00 & $0.3 \mathrm{~F}$ & $\underline{P}$ & 0 & & & & \\
\hline B4 & Cooneprionid os & 00 & $9 / 8$ & $P$ & of & & & & \\
\hline BS & Enellogma spp. & 00 & 918 & $P$ & of & & & & \\
\hline 86 & Nourocordulia obsolate & 00 & 5.4]F & $P$ & 0 & & & & \\
\hline 87 & Propomphus sp. & $\infty$ & 8.7 & $P$ & 0 & & & & \\
\hline 88] & Acronserria sbnormis & $P t$ & $2.2 . \mathrm{P}$ & $\mathbf{P}$ & 19.8 & & & 21 & 31 \\
\hline
\end{tabular}




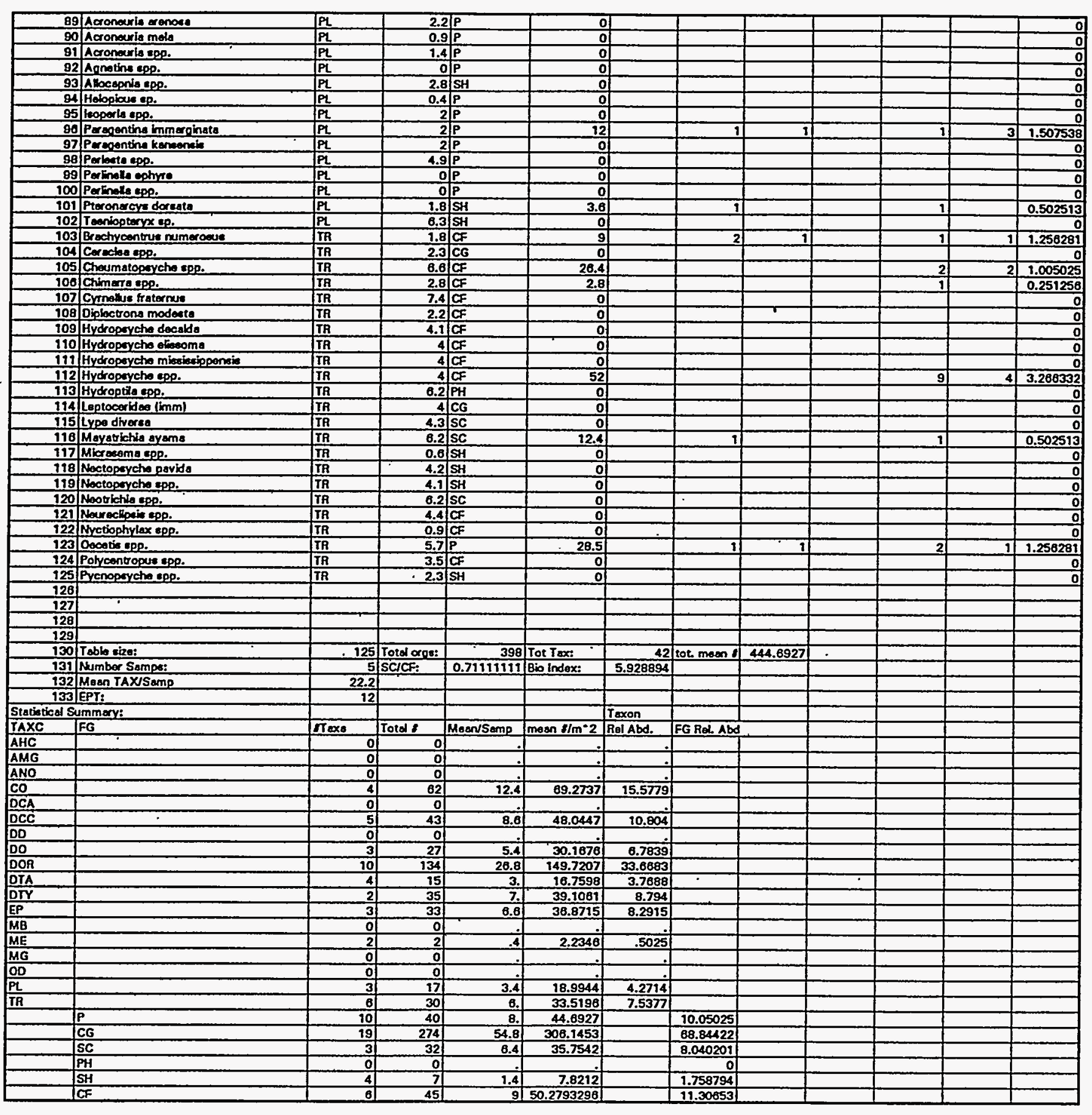




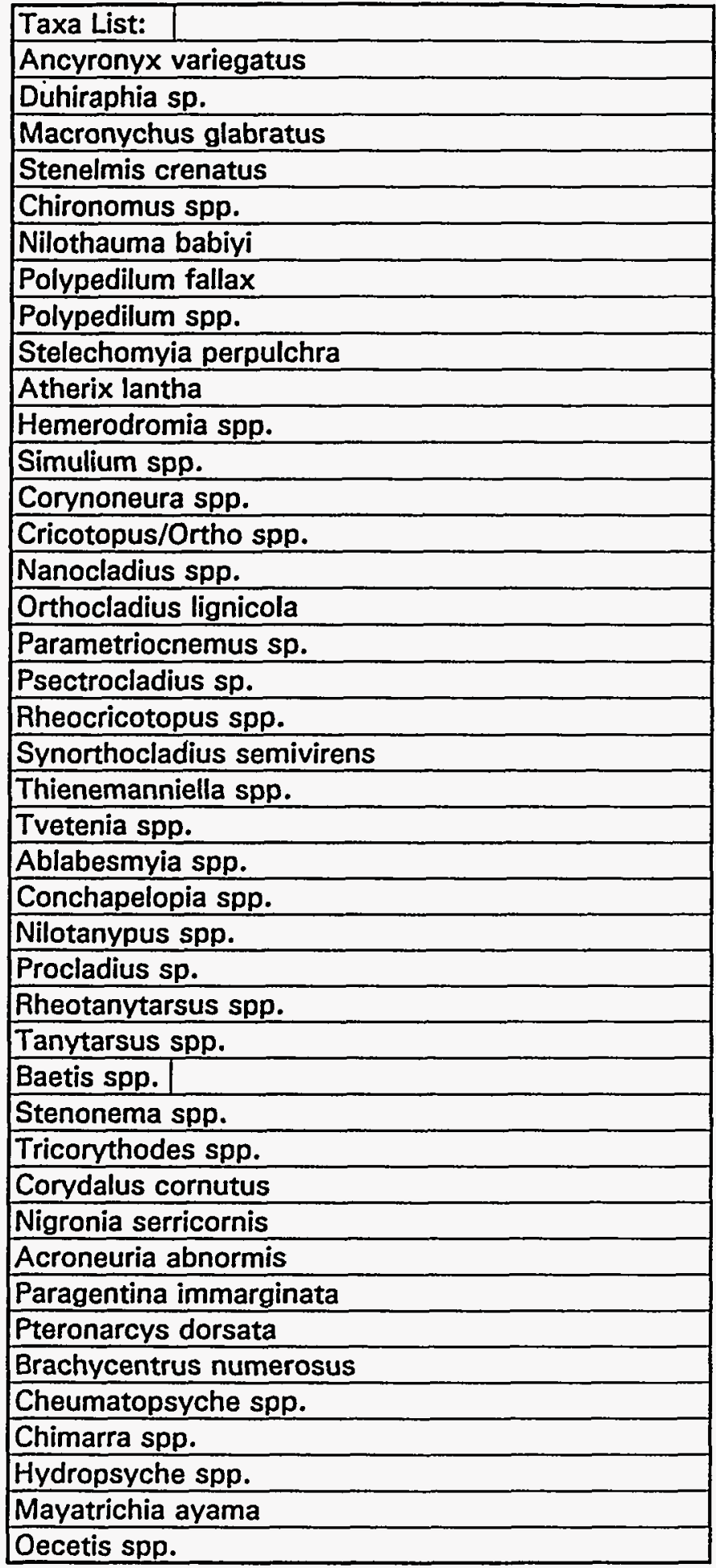

Taxa List:

Ancyronyx variegatus

Duhiraphia sp.

Macronychus glabratus

Stenelmis crenatus

Chironomus spp.

Nilothauma babiyi

Polypedilum fallax

Polypedilum spp.

Stelechomyia perpulchra

Atherix lantha

Hemerodromia spp.

Simulium spp.

Corynoneura spp.

Cricotopus/Ortho spp.

Nanocladius spp.

Orthocladius lignicola

Parametriocnemus sp.

Psectrocladius sp.

Rheocricotopus spp.

Synorthocladius semivirens

Thienemanniella spp.

Tvetenia spp.

Ablabesmyia spp.

Conchapelopia spp.

Nilotanypus spp.

Procladius sp.

Rheotanytarsus spp.

Tanytarsus spp.

Baetis spp.

Stenonema spp.

Tricorythodes spp.

Corydalus cornutus

Nigronia serricornis

Acroneuria abnormis

Paragentina immarginata

Pteronarcys dorsata

Brachycentrus numerosus

Cheumatopsyche spp.

Chimarra spp.

Hydropsyche spp.

Oecetis spp. 


\begin{tabular}{|c|c|c|c|c|c|c|c|c|c|c|c|c|}
\hline Seg. & Taxon & TAXC & NCBI & FG & (for Bl) & Sampler $\mathrm{Da}$ & & B & C & D & $E$ & Rel Abd \\
\hline & Rheocricotopus spp. & DOR & 7.3 & CG & 452.6 & & 7 & 4 & 20 & 27 & 4 & 15.57789 \\
\hline 2 & Polypedilum spp. & DCC & 6.9 & CG & 255.3 & & 5 & 4 & 5 & 15 & 8 & 9.296482 \\
\hline 3. & Stenelmis crenatus & CO & 5.4 & CG & 194.4 & & 3 & 6 & 7 & 5 & 15 & 9.045226 \\
\hline 4 & Thienemanniella spp. & DOR & & CG & 188 & & 6 & 6 & & 17 & 2 & 7.788945 \\
\hline 5 & Stenonema spp. & EP & 3.4 & $\mathrm{sc}$ & 95.2 & & 4 & & 5 & 14 & 5 & 7.035176 \\
\hline 6 & Macronychus glabratus & CO & 4.7 & CG & 108.1 & & 5 & 2 & 2 & 7 & 7 & 5.778894 \\
\hline & Cricotopus/Ortho spp. & DOR & 8.8 & LG & 184.8 & & 1) & B] & 21 & 12 & & 5.276382 \\
\hline
\end{tabular}




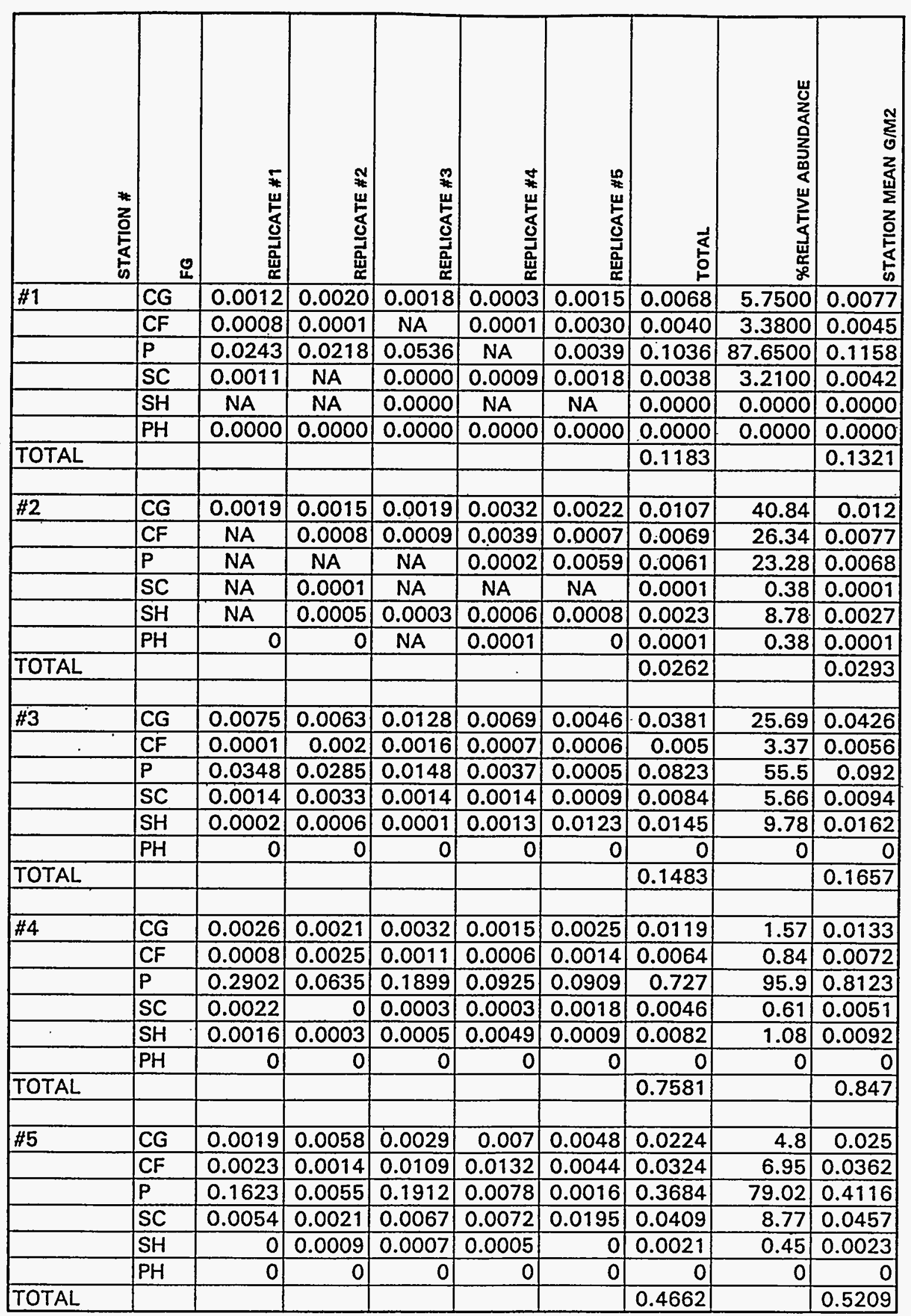




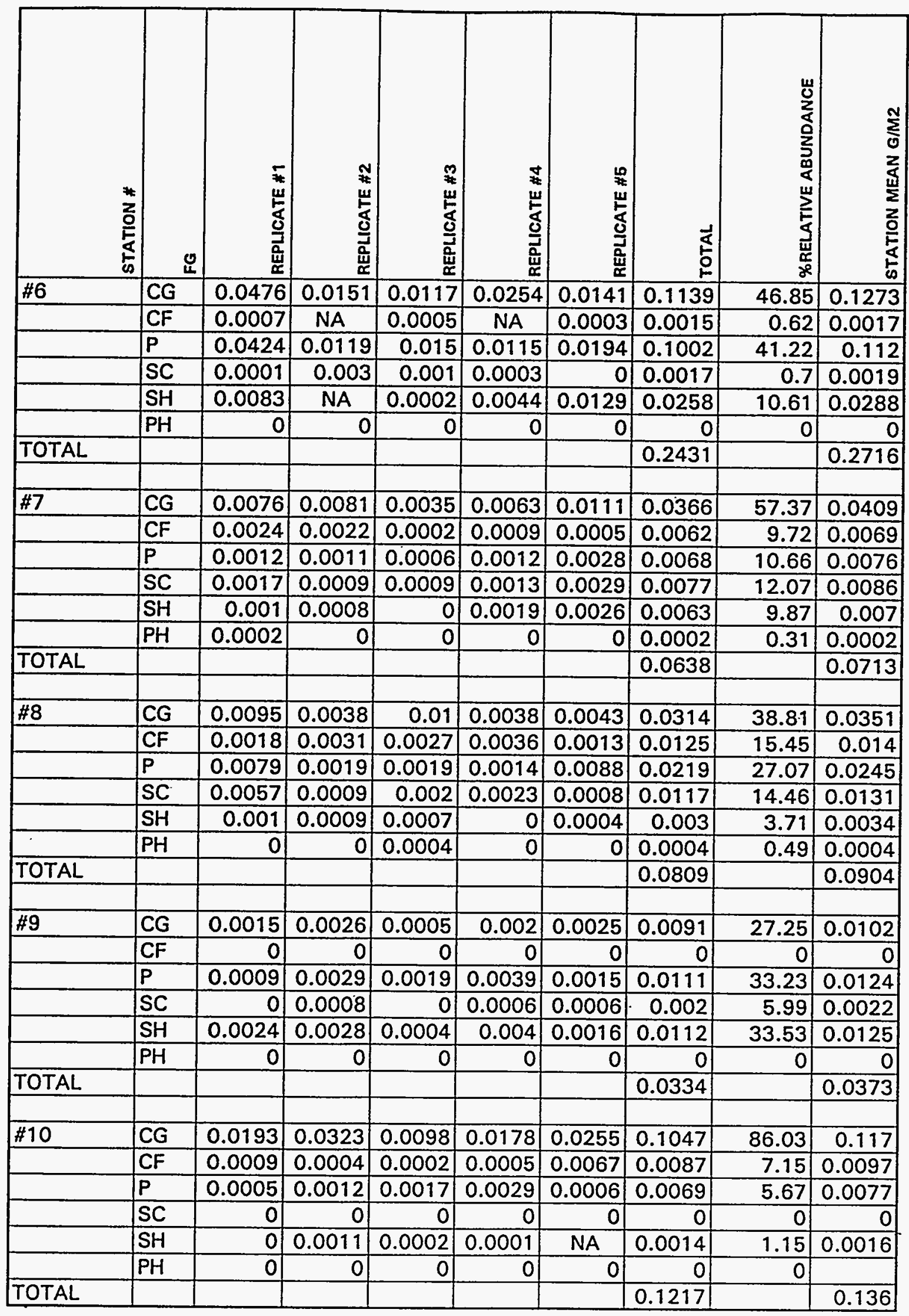




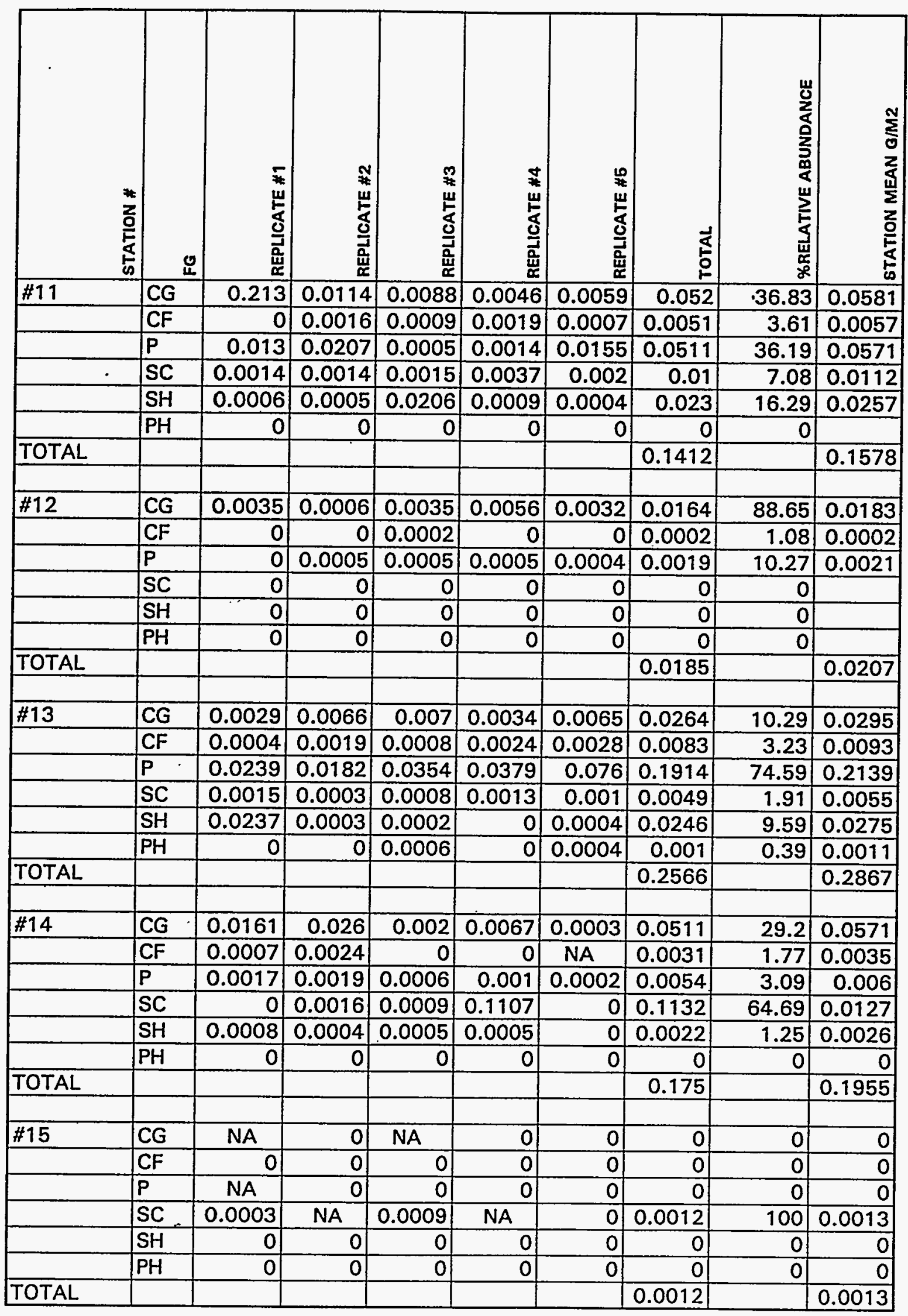




\begin{tabular}{|c|c|c|c|c|c|c|c|c|c|}
\hline 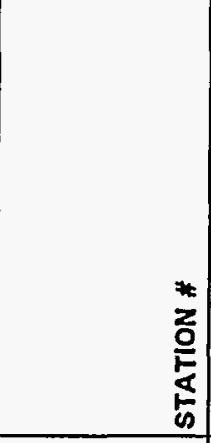 & 呆 & 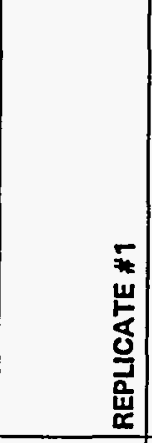 & 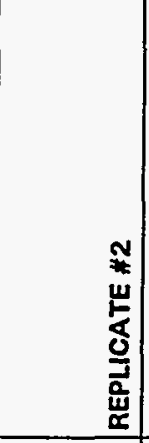 & 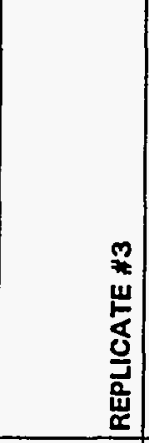 & 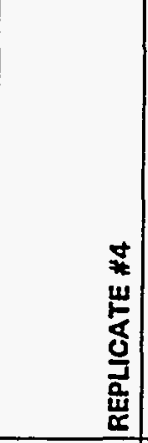 & 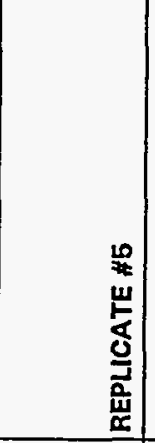 & $\begin{array}{l}1 \\
\mathbb{a} \\
5 \\
0\end{array}$ & 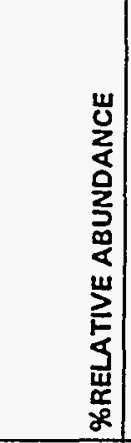 & 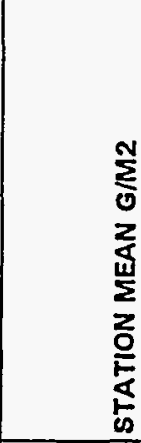 \\
\hline$\# 16$ & CG & 0.0016 & 0.0029 & 0.0009 & 0.0012 & 0.001 & 0.0076 & 33.63 & 0.0085 \\
\hline & $\mathrm{CF}$ & 0.0002 & 0 & 0.0001 & 0.0004 & 0 & 0.0007 & 3.1 & 0.0008 \\
\hline & $P$ & 0.0006 & 0.0011 & 0.0017 & \begin{tabular}{|l|}
0.0038 \\
\end{tabular} & 0.0024 & 0.0096 & 42.48 & 0.0107 \\
\hline & SC & 0.0005 & 0.0013 & 0.0009 & 0.0004 & 0.0005 & 0.0036 & 15.93 & 0.004 \\
\hline & $\mathrm{SH}$ & 0 & 0.0008 & 0 & 0.0003 & 0 & 0.0011 & 4.87 & 0.0012 \\
\hline & $\mathrm{PH}$ & 0 & 이 & 0 & 인 & 0 & 0 & 0 & 0 \\
\hline TOTAL & & & & & & & 0.0226 & & 0.0253 \\
\hline$\# 17$ & CG & 0.0018 & 0.0021 & 0.0014 & 0.0004 & 0.001 & 0.0067 & 51.54 & 0.0075 \\
\hline & CF & 0 & 0 & \begin{tabular}{|l|}
0 \\
\end{tabular} & 0 & 0 & 0 & 0 & 0 \\
\hline & $P$ & 0.0014 & 0.001 & 0.0007 & 0.0007 & 0.0005 & 0.0043 & 33.08 & 0.0048 \\
\hline & SC & 0.0009 & 0.0005 & 0 & 0 & 0 & 0.0014 & 10.77 & 0.0016 \\
\hline & $\mathrm{SH}$ & 0 & 0 & 0.0003 & 0.0003 & 0 & 0.0006 & 4.62 & 0.0007 \\
\hline & $\mathrm{PH}$ & of & 0 & 0 & 0 & 0 & 0 & 0 & 0 \\
\hline TOTAL & & & & & & & 0.013 & & 0.0145 \\
\hline$\# 18$ & CG & 0.001 & 0.0005 & NA & 0.0001 & 0.0014 & 0.003 & 11.32 & 0.0034 \\
\hline & $\mathrm{CF}$ & 0.0006 & NA & NA & NA & 0.0002 & 0.0008 & 3.02 & 0.0009 \\
\hline & $P$ & 0.0014 & 0.0015 & 0.0042 & 0.0048 & 0.001 & 0.0129 & 48.68 & 0.0144 \\
\hline & $\mathrm{SC}$ & 0.0002 & 0.002 & NA & NA & 0.0011 & 0.0033 & 12.45 & 0.0037 \\
\hline & $\mathrm{SH}$ & 0.0002 & 0.0001 & NA & 0.0052 & 0.001 & 0.0065 & 24.53 & 0.0073 \\
\hline & $\mathrm{PH}$ & NA & 0 & 0 & 0 & & 0 & 0 & \\
\hline TOTAL & & & & & & & 0.0267 & & 0.0296 \\
\hline \#19 & & & & & & & & & \\
\hline$\# 19$ & \begin{tabular}{|l} 
CG \\
CF
\end{tabular} & $\frac{0.0015}{0.0021}$ & $\begin{array}{l}0.0011 \\
0.0003\end{array}$ & $\begin{array}{l}0.0023 \\
0.0042\end{array}$ & $\begin{array}{l}0.0022 \\
0.0004\end{array}$ & $\begin{array}{l}0.0012 \\
0.0011\end{array}$ & $\frac{0.0083}{0.0081}$ & $\frac{32.94}{32.14}$ & $\frac{0.0093}{0.0091}$ \\
\hline & $P$ & 0.0012 & 0.0002 & \begin{tabular}{|l|}
0.0002 \\
\end{tabular} & NA & 0.001 & 0.0026 & 10.32 & 0.0029 \\
\hline & SC & 0.0014 & 0.0005 & 0.0017 & 0.0002 & 0.0014 & 0.0052 & 20.63 & 0.0058 \\
\hline & $\mathrm{SH}$ & 0.0002 & NA & 0 & 0.0001 & 0.0001 & 0.0004 & 1.59 & 0.0004 \\
\hline & $\mathrm{PH}$ & 0.0001 & 0.0001 & 0.0004 & NA & $\mathrm{NA}$ & 0.0006 & 2.38 & 0.0007 \\
\hline TOTAL & & & & & & & 0.0252 & & 0.0278 \\
\hline$\# 20$ & CG & 0.0002 & 0.002 & 0.002 & 0.002 & 0.0071 & 0.0133 & 21.38 & 0.0149 \\
\hline & $\mathrm{CF}$ & 0.0007 & 0.0011 & 0.0019 & 0.0022 & 0.0111 & 0.017 & 27.33 & 0.019 \\
\hline & $P$ & 0.0013 & 0.001 & 0.0009 & 0.0056 & 0.0018 & 0.0106 & 17.04 & 0.0118 \\
\hline & $\mathrm{SC}$ & 0.0013 & 0.0022 & 0.0022 & 0.0035 & 0.0092 & 0.0184 & 29.58 & 0.0206 \\
\hline & $\mathrm{SH}$ & 0 & 0.0003 & 0.0008 & 0 & 0.0004 & 0.0015 & 2.41 & 0.0017 \\
\hline & $\mathrm{PH}$ & $\mathrm{NA}$ & 0.0006 & 0.0002 & 0.0002 & 0.0004 & 0.0014 & 2.25 & 0.0016 \\
\hline TOTAL & & & & & & & 0.0622 & & 0.695 \\
\hline
\end{tabular}




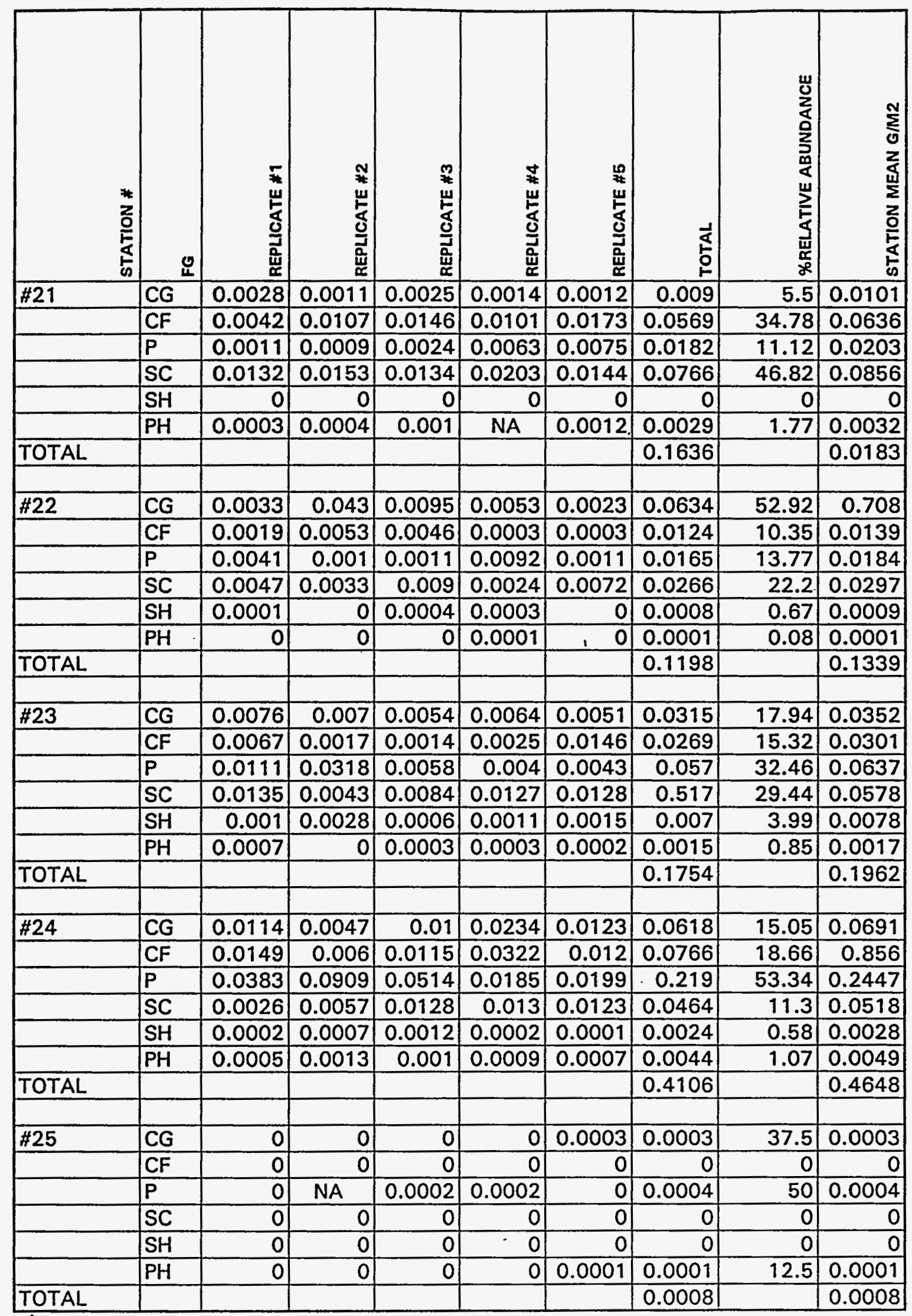




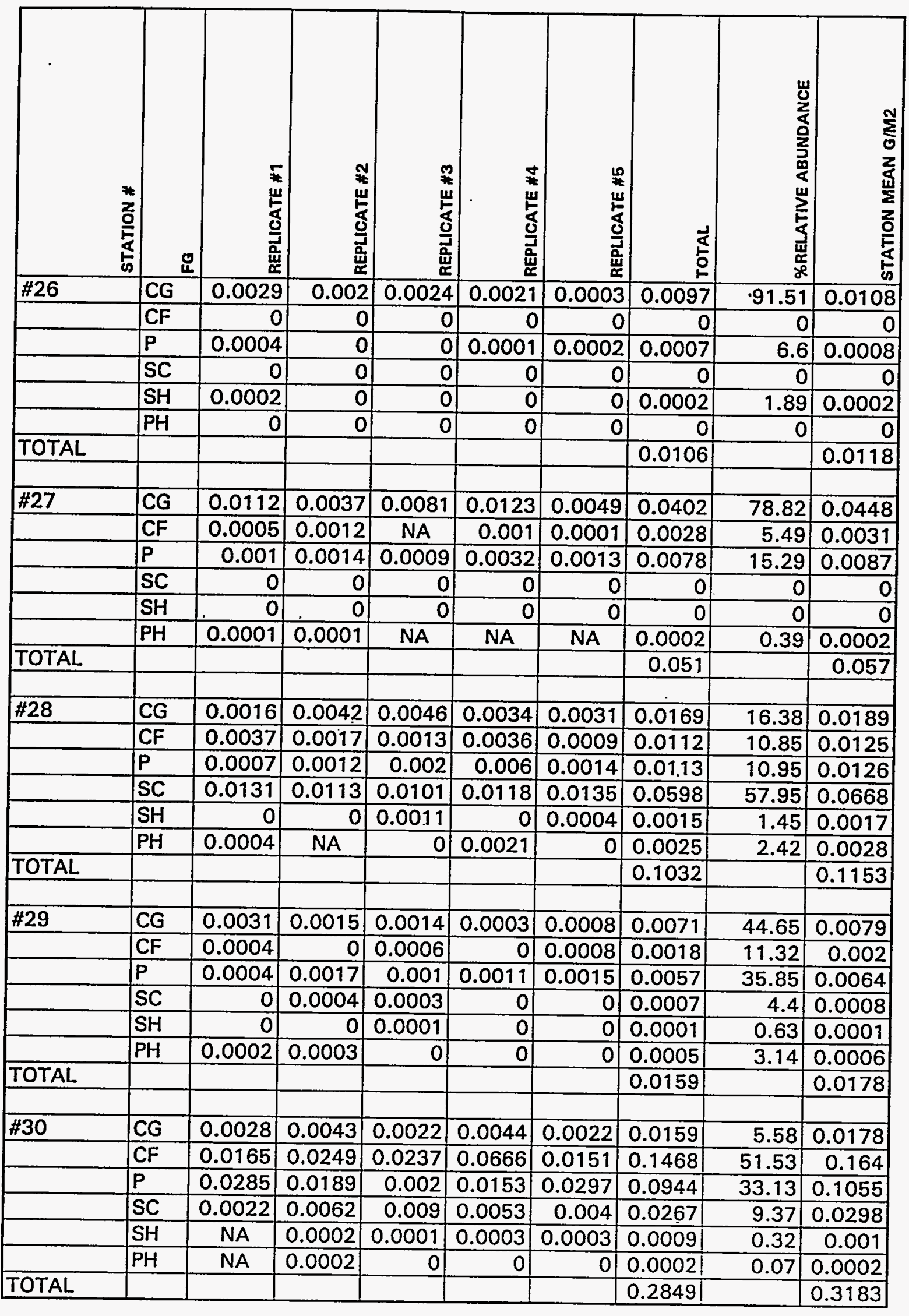




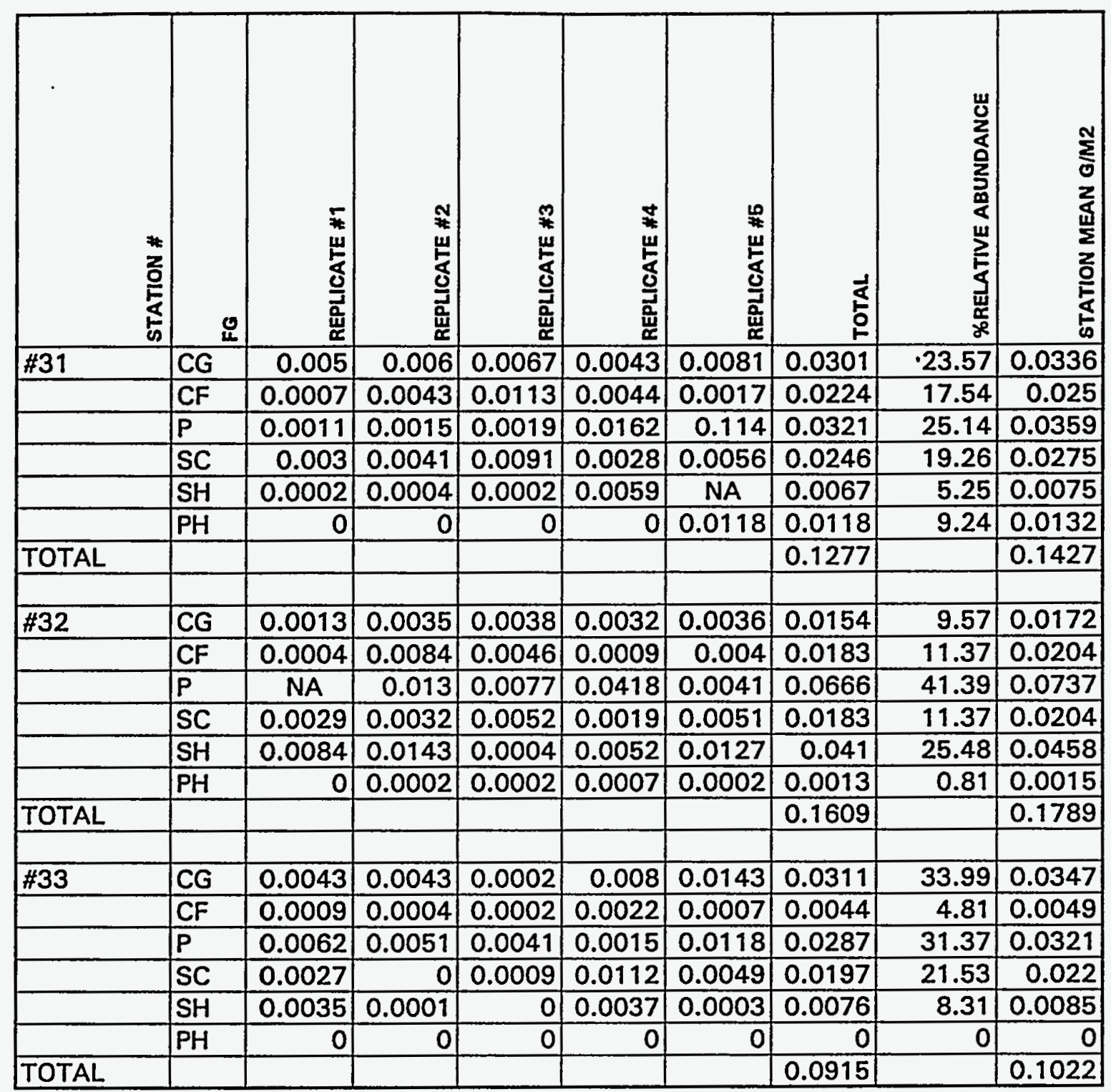

